TALITA SCUSSIATO

ESTUDO DO FLUXO DE AR EM SOLOS USANDO A TÉCNICA DE INJEÇÃO DE AR EM MODELOS FÍSICOS BIDIMENSIONAIS 
TALITA SCUSSIATO

\section{ESTUDO DO FLUXO DE AR EM SOLOS USANDO A TÉCNICA DE INJEÇÃO DE AR EM MODELOS FÍSICOS BIDIMENSIONAIS}

Dissertação apresentada à Escola

Politécnica da Universidade de São Paulo para obtenção do título de Mestre em

Engenharia

Área de concentração:

Engenharia Geotécnica

Orientador: Prof. Fernando A. M. Marinho

São Paulo

2012 
Autorizo a reprodução e divulgação total ou parcial deste trabalho, por qualquer meio convencional ou eletrônico, para fins de estudo e pesquisa, desde que citada a fonte.

Este exemplar foi revisado e alterado em relação à versão original, sob responsabilidade única do autor e com a anuência de seu orientador.

São Paulo, de junho de 2012.

Assinatura do autor

Assinatura do orientador

FICHA CATALOGRÁFICA

Scussiato, Talita

Estudo do fluxo de ar em solos usando a técnica de injeção de ar em modelos físicos bidimensionais / T. Scussiato. -ed.rev. -- São Paulo, 2012.

$164 \mathrm{p}$.

Dissertação (Mestrado) - Escola Politécnica da Universidade de São Paulo. Departamento de Engenharia de Estruturas e Geotécnica.

1.Injeção (Engenharia) 2.Mecânica dos solos 3.Fluxo de ar 4.Zona de influência 5.Modelos físicos bidimensionais I.Universidade de São Paulo. Escola Politécnica. Departamento de Engenharia de Estruturas e Geotécnica II.t. 
DEDICATÓRIA

Dedico este trabalho aos meus pais Zeferino Scussiato e Ivone Nogueira Scussiato 


\section{AGRADECIMENTOS}

Agradeço a Deus por tudo.

Aos meus pais pelo esforço e dedicação para a minha formação.

Ao meu orientador Fernando A. M. Marinho pela orientação e ensinamentos passados durante este trabalho.

Aos professores da Pós-Graduação em Geotecnia da Escola Politécnica da Universidade de São Paulo: Faiçal Massad, Waldemar Hachich, Marcos Massao Futai, José Jorge Nader, Maria Eugênia Boscov e Carlos de Souza Pinto pelo conhecimento transmitido dentro e fora da sala de aula.

Aos funcionários do Laboratório de Mecânica dos Solos da Escola Politécnica (LMS) pelo auxílio e paciência durante a parte experimental do trabalho, Antônio Carlos Heitzmann e Joaquim Costa.

Aos professores Paulo Roberto Chameki e Alessander C. Morales Kormann pela ajuda durantes os meus primeiro passos no ramo da Geotecnia.

A Roberta Bonfim Boszczowski e a Laryssa Petry Ligocki por me apresentarem a Mecânica dos Solos.

Ao meu chefe Maurício Hiromi Yamaji pela compreensão e apoio durante a fase final deste trabalho.

Ao meu amigo e namorado William Hideki Ito pela ajuda e compreensão durante os anos do mestrado.

O apoio financeiro concedido pela CAPES através da bolsa.

A todas as pessoas que contribuíram direta ou indiretamente para a realização deste trabalho. 
"O ensino deveria ser assim: quem o receba o recolha como um dom inestimável, mas nunca como uma obrigação penosa."

(Albert Einstein) 


\section{RESUMO}

O método de injeção de ar é utilizado para a descontaminação de solos e lençóis freáticos contaminados com Compostos Orgânicos Voláteis (VOCs). O ar injetado no solo na zona saturada, ao subir para a zona não saturada, volatiliza os contaminantes. A eficiência da remediação por esse método está diretamente ligada à região de solo em que ocorre o fluxo de ar. Essa região é denominada de zona de influência e é afetada por vários fatores tais como: tipo e estrutura do solo, permeabilidade e pressão de injeção. No presente trabalho foram realizados estudos de fluxo de ar em solos saturados em um modelo físico bidimensional com o objetivo de avaliar a zona de influência formada. Os ensaios bidimensionais têm por finalidade a visualização dessa zona de influência; para isso foi utilizado um tanque transparente feito de placas de acrílico. Para a realização dos ensaios foram utilizados três tipos distintos de solo, uma areia natural denominada de Areia Osasco, uma areia comercial e uniforme (Areia do IPT) e um solo residual utilizado para criar as lentes de baixa permeabilidade. Também foram realizados ensaios de laboratório para a caracterização dos solos em estudo, tais como: curva de retenção, índice de vazios máximo e mínimo, granulometria, permeabilidade a água e ao ar. Os ensaios realizados no modelo (tanque) mostraram, como visto na literatura, que a granulometria e a estrutura do solo são as principais responsáveis pela formação de caminhos preferenciais de ar no solo. A zona de influência formada durante a injeção de ar nos ensaios com a Areia Osasco não foi simétrica devido à heterogeneidade do solo, já a formada nos ensaios com a Areia do IPT foi simétrica por causa da uniformidade do solo. A Areia do IPT apresentou uma zona de influência mais estreita do que a da Areia Osasco, isso ocorreu em função da menor porosidade da Areia Osasco, pois quanto menor a porosidade maior a tortuosidade e maior a expansão lateral. Os ensaios com as lentes de baixa permeabilidade mostraram que pequenas variações na configuração do solo podem influenciar a eficiência do método já que a região logo acima das lentes não foi atingida pelo ar. $\mathrm{O}$ aumento da pressão de injeção durante os ensaios fez com que mais canais de ar fossem formados causando um aumento do tamanho da zona de influência.

Palavras chave: Zona de Influência. Fluxo de Ar. Injeção de Ar. Modelo Físico Bidimensional. 


\begin{abstract}
The method of air sparging is used for remediation of soil and groundwater contaminated with Volatile Organic Compounds (VOCs). In this process the air is injected into the soil in the saturated zone to ascend to the vadose zone and volatilizes the contaminants. The efficiency of air flow remediation is directly linked with the region of soil in which the flow occurs. This region is called as zone of influence and is affected by several factors such as: type and structure of the soil, permeability and pressure of injection. In the present work the air flow in saturated soils was investigated using a bidimensional physical model to evaluate the zone of influence formed. The objective of the tests was to obtain informations about zone of influence. A transparent tank made by acrylic plates was used. For these tests it was used three different types of soil: natural sand, called Osasco sand, a commercial and uniform sand called IPT sand and a residual soil used to create the lenses with low permeability. Laboratory tests such as water retention, minimum and maximum voids ratio, water and air permeability were performed to characterize the soils used in this study. Tests performed in the model (tank) showed, like those in the literature, that the particle size and soil structure are mainly responsible to create the preferential paths of air in soil. The zone of influence formed during the injection of air in the tests with Osasco sand was not symmetrical due to the heterogeneity of the soil; on the other hand the test performed with IPT sand was symmetrical due to its uniformity. The IPT sand showed a narrower zone of influence than Osasco sand, this was due to the lower porosity of the Osasco sand. Lower porosity imply in higher tortuosity and greater lateral expansion. Testes performed with low permeability lenses within the sand showed that small variations in the structure of the soil can affect the efficiency of the method because the region immediately above the lens is not reached by the air. The increase in the pressure of injection during the experiments induced the formation of more air channels causing an increase in the size of the zone of influence.
\end{abstract}

Keywords: Zone of Influence. Air Flow. Air Sparging. Bidimensional Physical Model 


\section{Sumário}

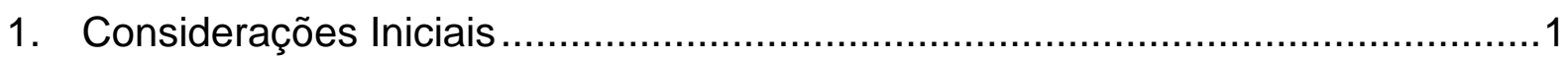

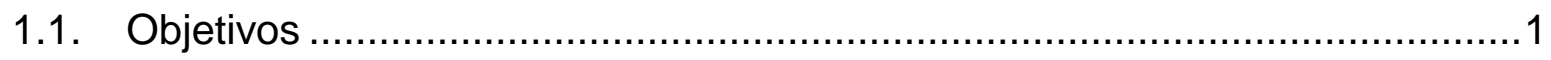

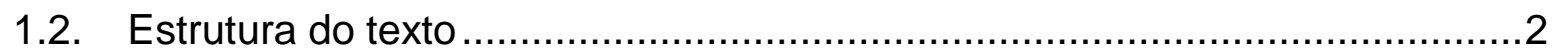

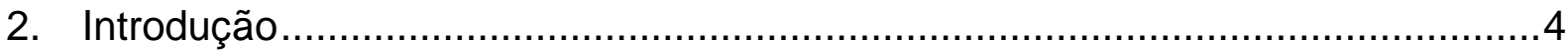

2.1. Contaminantes derivados do petróleo ..................................................

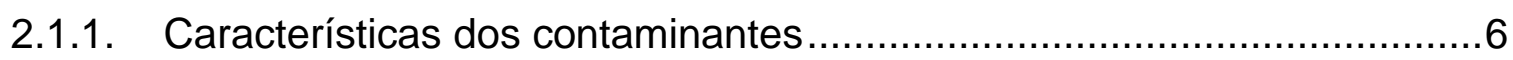

2.2. Remediação pelo método de injeção de ar .............................................10

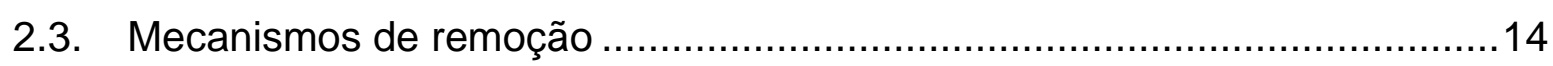

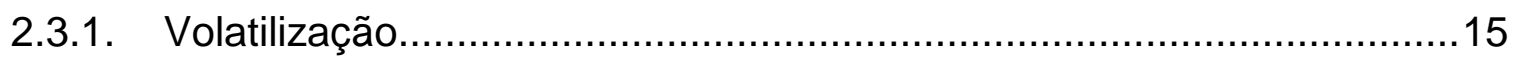

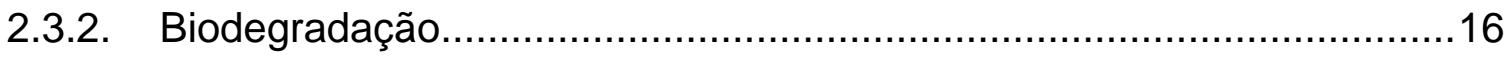

3. Características da técnica de injeção de ar ..................................................18

3.1. Sistema de Variáveis..................................................................... 18

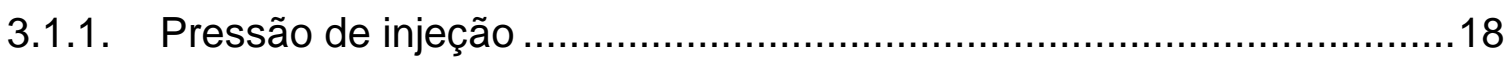

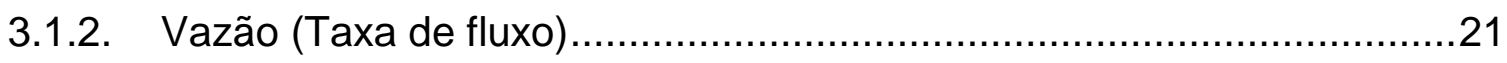

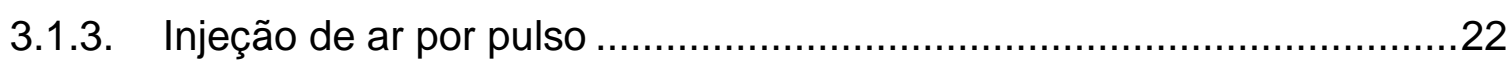

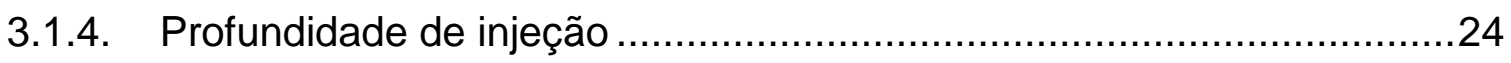

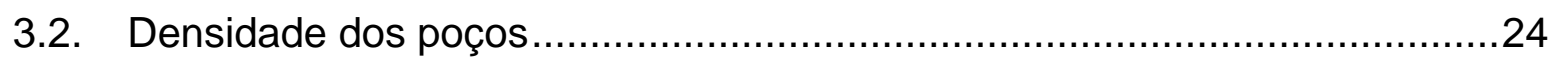

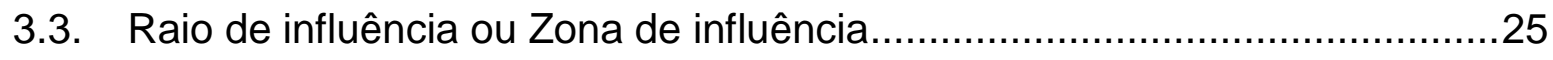

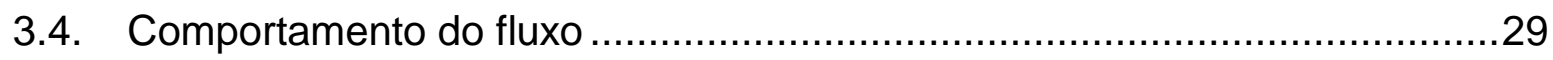

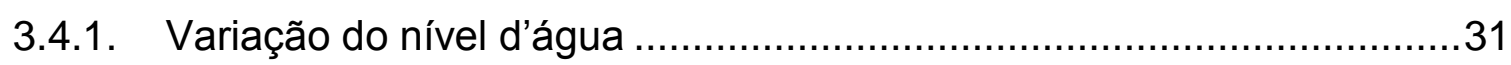

3.5. Agitação da água subterrânea ............................................................ 33

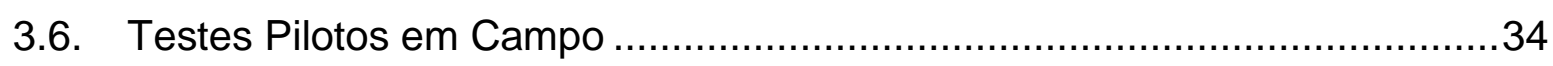

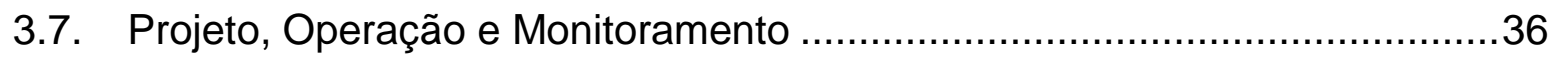

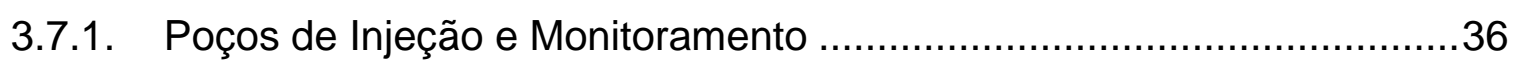

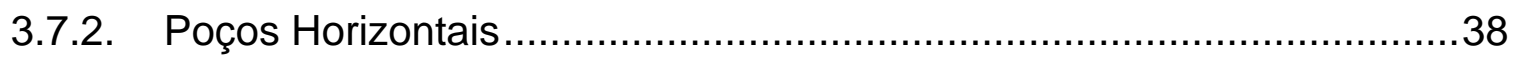

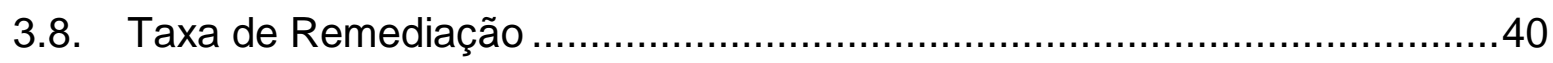

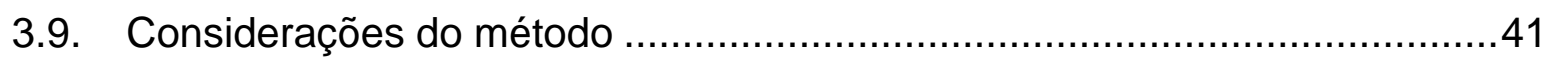

3.10. Algumas modificações do sistema convencional de injeção de ar.............43

3.10.1. Recuperação de vapor por trincheiras ................................................ 43

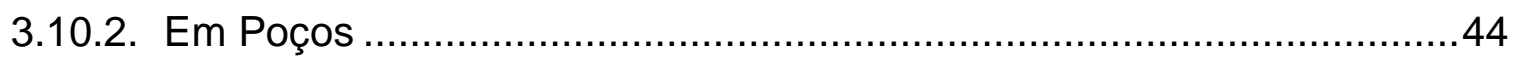

4. Padrão do Fluxo de ar em Modelos Físicos......................................................46

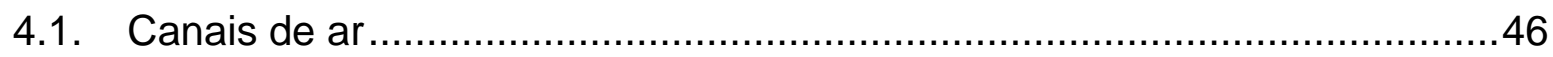

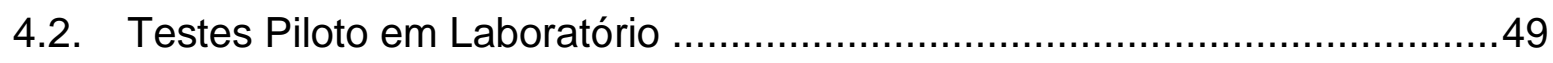

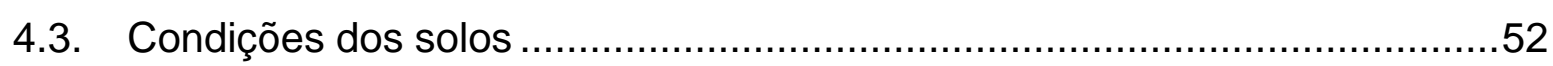

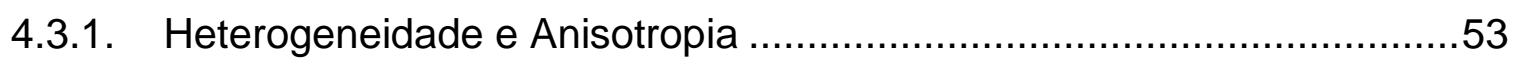

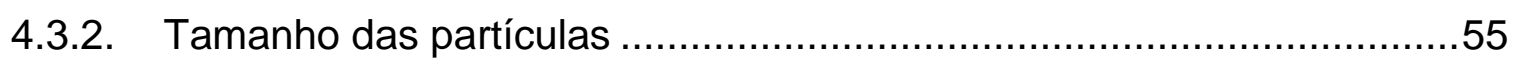




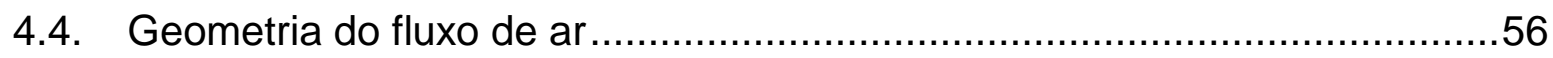

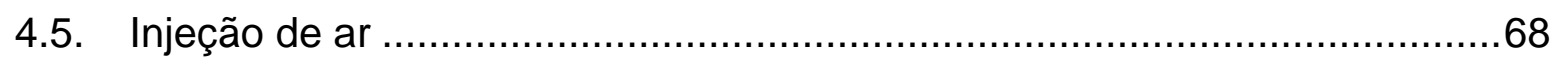

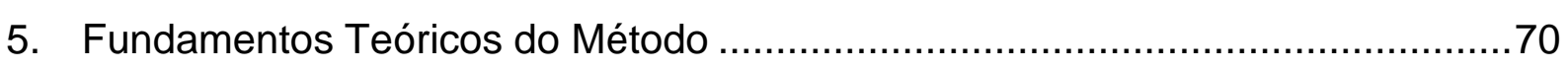

5.1. Fluxo de gases no solo - Advecção.................................................... 70

5.1.1. Lei de Darcy para fluxo de gases .................................................... 70

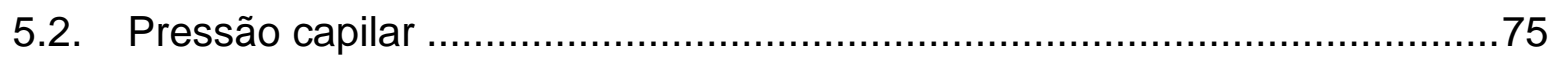

5.3. Transporte e transferência de massa....................................................

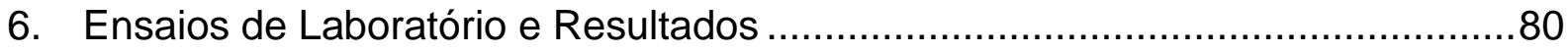

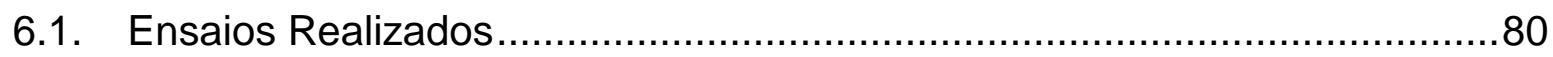

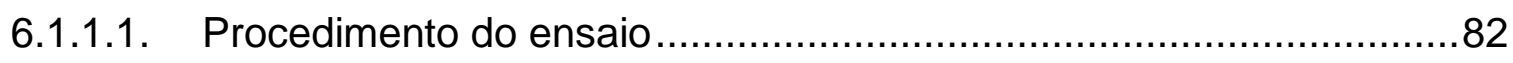

6.1.1.2. Modelo proposto por Brooks e Corey (1964)................................. 83

6.1.1.1. Modelo proposto por Van Genuchten (1980) ................................... 84

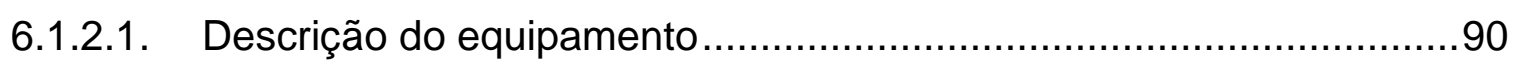

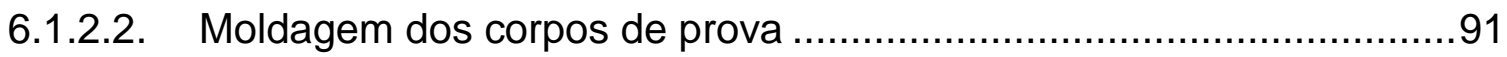

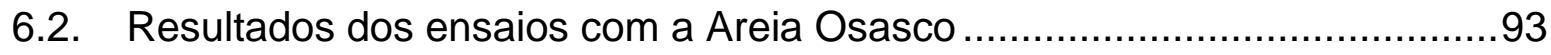

6.3. Resultados dos ensaios com a Areia do IPT ........................................102

6.4. Resultados dos ensaios com as lentes de baixa permeabilidade ..............109

7. Ensaios com o Modelo Físico Bidimensional em Laboratório .............................113

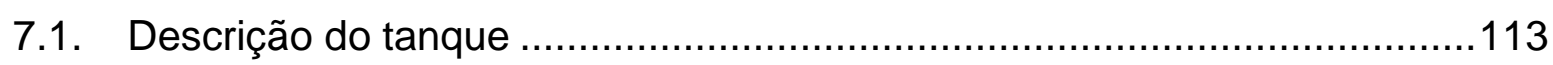

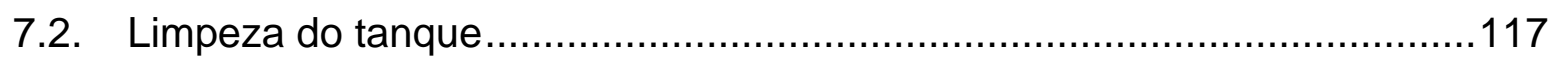

7.3. Ensaios com o modelo físico bidimensional (tanque) ..............................118

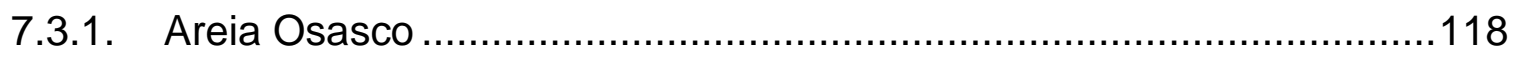

7.3.2. Homogeneização da Areia no Tanque ...........................................121

7.3.3. Ensaios com a Areia Osasco Depois da Homogeneização ..................124

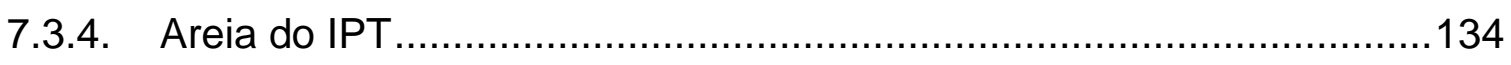

7.3.5. Areia do IPT com lentes de baixa permeabilidade.............................140

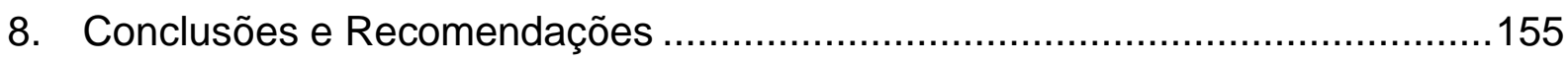

8.1. Recomendações para estudos posteriores ..........................................157

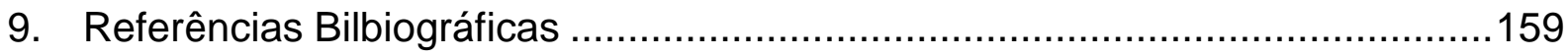




\section{Lista de Figuras}

Figura 2.1 - Localização da pluma de contaminação em (a) pode ser visto o LNAPL e em (b) o DNAPL ....................................................................6

Figura 2.2 - Condições do contaminante no solo (modificado de Suthersan, 1997) ...6 Figura 2.3 - Método de injeção de ar associado com o método de extração de vapores (SVE) (adaptado de Johnson (1998)) .................................11

Figura 2.4 - Método de injeção de ar associado com o método de extração de vapores (SVE) (adaptado de EPA (1994)) ......................................12

Figura 2.5 - NAPL dissolvendo e difundindo pelos canais de ar (adaptada de Baker e Benson (1996))

Figura 3.1 - Esquema típico de injeção de ar (adaptado de Baker e Benson (1996))

Figura 3.2 - Dois caminhos de fluxo de ar hipotéticos (adaptado de Lundegard e Labrecque (1995))

Figura 3.3 - Comportamento do fluxo, em (a) fase de expansão, (b) inicio do colapso e (c) estado de equilíbrio (USACE (2008))

Figura 3.4 - Expansão do nível d'água (adaptado de Suthersan (1997)) ..................31

Figura 3.5 - Estado de equilíbrio durante a injeção de ar (adaptado de Suthersan (1997))

Figura 3.6 - Desenho esquemático mostrando a argamassa e o filtro (adaptada de Johnson et al. (1993)). 37

Figura 3.7 - Poço de injeção horizontal (modificado de EPA (1994)) ........................39

Figura 3.8 - Trincheiras (adaptado de Suthersan (1997)) .....................................44

Figura 3.9 - Injeção de ar em poços (adaptado de Suthersan (1997)) .....................45

Figura 4.1 - Dois modelos conceituais possíveis para o fluxo de ar durante a injeção, (a) Canais de Ar e (b) Fluxo Contínuo (adaptado de Clayton (1998)) ..47

Figura 4.2 - Modelo conceitual mais detalhado para o fluxo de ar durante a injeção, comparação entre areia grossa e fina (adaptado de Clayton (1998)) ...48

Figura 4.3 - Fluxo em câmara em areia após 113 horas de injeção de ar em (a) pode ser vista a foto do experimento e em (b) um desenho do fluxo de ar (adaptada de Peterson et al. (2001))

Figura 4.4 - Desenhos dos canais de ar com vazão moderada em (a) e alta em (b) para partículas de $0,75 \mathrm{~mm}$, ensaio realizado em bolinhas de vidro ( $\mathrm{Ji}$ et al. (1993))).

.52

Figura 4.5 - Desenhos esquemáticos dos canais de ar em um modelo com bolinhas de vidro que simulam lentes de baixa permeabilidade (Jl et al., 1993) 54

Figura 4.6 - Esquema de canais de ar mostrando a interface entre ar e água (adaptado de (AHLFELD; DAHMANI; JI, 1994)) .56

Figura 4.7 - Fluxo por bolhas em (a) e fluxo segmentado lento (slug) em (b) (modificado de Marulanda (2001) depois de Taitel, 1980) ...................58

Figura 4.8 - Geometria do fluxo de ar em (a) partículas com diâmetro médio menor que $1,3 \mathrm{~mm}$, fluxo por canais discretos em (b) partículas com diâmetro médio maior que $1,84 \mathrm{~mm}$, fluxo difuso (adaptado de Peterson; Lepczyk e Lake (1999))....

Figura 4.9 - Geometria dos canais de fluxo de ar em (a) areia grossa e (b) areia bem graduada (adaptado de Reddy e Adams (2001)) 60

Figura 4.10 - Fluxo de ar em areia bem graduada entre areia grossa uniforme (adaptado de Reddy e Adams (2001)) 61 
Figura 4.11 - Fluxo de ar em cascalho fino embaixo de areia grossa uniforme (Adaptado de Reddy e Adams (2001)) ...........................................62

Figura 4.12 - Fluxo de ar em cascalho fino entre duas camadas de areia grossa (adaptado de Reddy e Adams (2001)) ...........................................63

Figura 4.13 - Caminhos de ar sinuosos (Ji et al. (1993)) .65

Figura 4.14 - Desenho esquemático do poço de injeção com pedra porosa na ponta para a distribuição do ar em (a) e tanque com injeção de ar através de difusor em (b) 68

Figura 5.1 - Esquema de fluxo por uma seção de área $A$ e comprimento $L$.............74 Figura 5.2 - Canais de ar com vários tamanhos e saturações de ar (adaptado de USACE (2008)) 78

Figura 6.1 - Desenho conceitual do efeito da histerese na curva de retenção (adaptada de LU e LIKOS, 2004).

Figura 6.2 - Placa de sucção durante o processo de montagem do ensaio. 82

Figura 6.3 - Relação teórica entre a condutividade á água versus condutividade ao ar.

Figura 6.4 - Relação entre a permeabilidade intrínseca, a condutividade a água e ao ar. (modificado de EPA, 1996) . 87

Figura 6.5 - Equipamento utilizado no ensaio de permeabilidade ao ar. .................91

Figura 6.6 - Montagem do ensaio de permeabilidade ao ar ..................................93

Figura 6.7 - Curva granulométrica da areia Osasco. ..........................................94

Figura 6.8 - Curva de retenção de água da Areia Osasco em termos de saturação.

Figura 6.9 - Curva de retenção de água da Areia Osasco em termos de teor de umidade volumétrica. ...................................................................99

Figura 6.10 - Curva de retenção de água da Areia Osasco e o ajuste do modelo de Brooks e Corey. .98

Figura 6.11 - Curva de retenção de água da Areia Osasco e o ajuste do modelo pelo Splintex.

Figura 6.12 - Gráfico mostrando a variação da Condutividade ao ar com a saturação de água para a Areia Osasco.

Figura 6.13 - Gráfico da permeabilidade intrínseca versus o inverso da pressão média, para a Areia Osasco......................................................101

Figura 6.14 - Gráfico da Condutividade a água pelo índice de vazios, Areia Osasco.

Figura 6.14-Grático da Condutividade a água pelo indice de vazios, Areia Osasco.

Figura 6.15 - Curva granulométrica da Areia do IPT ........................................103

Figura 6.16 - Curva de retenção de água da Areia do IPT em termos de saturação.

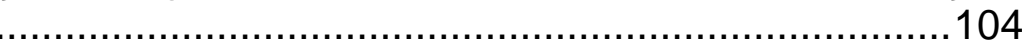

Figura 6.17 - Curva de retenção de água da Areia do IPT em termos de teor de umidade volumétrica. .................................................................105

Figura 6.18 - Curva de retenção de água da Areia do IPT e o ajuste do modelo de Brooks e Corey. 106

Figura 6.19 - Gráfico mostrando a variação da Condutividade ao ar com a saturação de água para a Areia do IPT.

Figura 6.20 - Gráfico da permeabilidade intrínseca versus o inverso da pressão média, para a Areia do IPT. ......................................................108

Figura 6.21 - Gráfico da Condutividade a água pelo índice de vazios, Areia do IPT.

........................................................................................... 109

Figura 6.22 - Curva granulométrica do solo residual de gnaisse (dados obtidos de Oliveira, 2004). 
Figura 6.23 - Curva de retenção de água das lentes de baixa permeabilidade em termos de teor de umidade volumétrica (dados obtidos de Oliveira, 2004).

Figura 6.24 - Curva de retenção de água das lentes de baixa permeabilidade em termos de teor de umidade volumétrica (dados obtidos de Oliveira, 2004).

Figura 6.25 - Curva de retenção de água das lentes de baixa permeabilidade e o ajuste feito pelo modelo de Van Genuchten (1980).

Figura 7.1 - Dimensões do modelo físico bidimensional utilizado nos ensaios de injeção de ar. 114

Figura 7.2 - Instalação do difusor 115

Figura 7.3 - Partes do difusor usado na injeção de ar 115

Figura 7.4 - Difusor montado, seus furos e suas dimensões. 116

Figura 7.5 - Detalhe da conexão da injeção de ar com o difusor. 117

Figura 7.6 - Fotos da limpeza do tanque após a término dos ensaios. 118

Figura 7.7 - Primeiro ensaio realizado com o tanque, em (a) a areia sendo colocada no tanque e em (b) as camadas da areia após a sedimentação........120

Figura 7.8 - Caminhos formados durante a injeção de ar no primeiro ensaio, Areia Osasco. 121

Figura 7.9 - Detalhe da bolha de ar aprisionada durante o ensaio. .......................121

Figura 7.10 - Fotos da homogeneização da areia no tanque. .............................122

Figura 7.11 - Curvas granulométricas da Areia Osasco antes e depois dos ensaios com o tanque. 123

Figura 7.12 - Formação de canais de ar no segundo ensaio, Areia Osasco. .........125

Figura 7.13 - Desenho esquemático mostrando o caminho seguido pelo ar durante a injeção, no segundo ensaio. 126

Figura 7.14 - Foto do arranjo do tanque antes do terceiro ensaio. ........................127

Figura 7.15 - Formação de canais de ar no terceiro ensaio, Areia Osasco...........127

Figura 7.16 - Desenho esquemático mostrando os canais de ar formados no terceiro ensaio...................................................................................... 128

Figura 7.17 - Formação de canais de ar no quarto ensaio, Areia Osasco.............129

Figura 7.18 - Desenho esquemático mostrando os canais de ar formados durante o quarto ensaio. 130

Figura 7.19 - Desenhos dos caminhos de ar durante o quarto ensaio. Em (a) logo após a aplicação e em (b) 1 hora após a aplicação contínua da mesma pressão.

Figura 7.20 - Quinto ensaio da Areia Osasco antes da injeção de ar...................131

Figura 7.21 - Detalhe dos canais de ar formados durante a injeção de ar no quinto ensaio

Figura 7.22 - Desenho esquemático mostrando os canais de ar, quinto ensaio da Areia Osasco. 132

Figura 7.23 - Quinto ensaio com a Areia Osasco, processo de formação dos canais de ar.

Figura 7.24 - Formação e desaparecimento de bolha de ar próximo a superfície durante o quinto ensaio, Areia Osasco. 134

Figura 7.25 - Primeiro ensaio Areia do IPT, arranjo em camadas. 135

Figura 7.26 - Foto durante a injeção de ar no primeiro ensaio da Areia do IPT. ....136

Figura 7.27 - Detalhe dos canais de ar formados durante a injeção, nota-se o movimento lateral. 
Figura 7.28 - Desenho esquemático mostrando os canais de ar durante o primeiro ensaio com a Areia do IPT

Figura 7.29 - Segundo ensaio com a Areia do IPT.........................................138

Figura 7.30 - Terceiro ensaio com a Areia do IPT. ..........................................139

Figura 7.31 - Desenho esquemático do segundo e do terceiro ensaio com a Areia do IPT. 140

Figura 7.32 - Primeira etapa de montagem do ensaio com lentes de baixa permeabilidade. Em (a) desenho esquemático e em (b) foto da primeira camada de Areia do IPT. 142

Figura 7.33 - Segunda etapa de montagem do primeiro ensaio com lentes de baixa permeabilidade. Em (a) desenho esquemático mostrando a primeira lente, em (b) colocação das barras de PVC, em (c) colocação do solo residual e em (d) colocação da areia nas laterais. 143

Figura 7.34 - Terceira etapa de montagem do primeiro ensaio com lentes de baixa permeabilidade. Em (a) desenho esquemático e em (b) foto da primeira lente entre as camadas de Areia do IPT.

Figura 7.35 - Quarta etapa de montagem do ensaio com lentes de baixa permeabilidade. Em (a) desenho esquemático mostrando as três lentes e em (b) montagem da segunda barreira de lentes. 144

Figura 7.36 - Quinta etapa de montagem do ensaio com lentes de baixa permeabilidade. Em (a) desenho esquemático e em (b) montagem completa aguardando a saturação por capilaridade. 145

Figura 7.37 - Primeiro ensaio com as lentes de baixa permeabilidade. Em (a) arranjo após saturação antes da injeção de ar e em (b) detalhe da saturação incompleta.

Figura 7.38 - Primeiro ensaio com as lentes de baixa permeabilidade, durante a injeção de ar 146

Figura 7.39 - Desenho esquemático mostrando o caminho percorrido pelo ar. .....147

Figura 7.40 - Segundo ensaio com as lentes de baixa permeabilidade pressão de injeção de ar de $50 \mathrm{kPa}$.

Figura 7.41 - Desenho esquemático mostrando os canais de ar formados durante o segundo ensaio com as lentes de baixa permeabilidade.

Figura 7.42 - Primeira e segunda etapas da segunda montagem do tanque com lentes de baixa permeabilidade. Em (a) desenho esquemático e em (b) montagem da primeira lente.

Figura 7.43 - Terceira etapa de montagem. Em (a) desenho esquemático, em (b) colocação do silte, (c) colocação da areia sobre a primeira lente e (d) colocação dos $13 \mathrm{~cm}$ de areia.

Figura 7.44 - Quarta e quinta etapas de montagem do tanque com lentes. Em (a) desenho esquemático, em (b) colocação da areia no centro entre as lentes, (c) colocação do silte para a formação das lentes e (d) colocação da areia sobre as lentes.

Figura 7.45 - Tanque antes do terceiro ensaio com as lentes de baixa permeabilidade. 151

Figura 7.46 - Terceiro ensaio de injeção de ar com lentes de baixa permeabilidade, nota-se os canais de ar formados. 151

Figura 7.47 - (a) detalhe da não uniformidade da primeira lente de baixa permeabilidade antes da injeção de ar e em (b) após injeção. ...........152

Figura 7.48 - Desenho esquemático mostrando os caminhos percorridos pelo ar. 153 
Figura 7.49 - Detalhe da passagem de ar no contato entre o silte e a areia em (a) lado esquerdo e em (b) lado direito do tanque.................................153

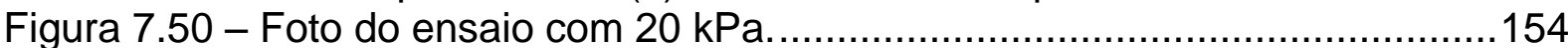

Figura 7.51 - Detalhe dos canais de ar passando pela primeira lente de baixa permeabilidade.............................................................. 154 


\section{Lista de Tabelas}

Tabela 2.1 - Contaminantes e suas características (valores de pressão de vapor e constante da Lei de Henry retirados de Suthersan (1997)) ........................

Tabela 3.1 - Valores de vazão encontrados na literatura. ……………………...........

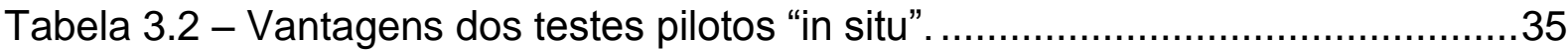

Tabela 3.3 - Espaçamentos entre poços encontrados na Literatura. ........................38

Tabela 3.4 - Orientação do poço de injeção (adaptado de EPA (1994)) ....................38

Tabela 3.5 - Condições favoráveis para a utilização do método (adaptada de Suthersan, 1997) ......................................................................... 43

Tabela 4.1 - Concentrações de ferro dissolvido que podem atrapalhar a injeção de ar (adaptado de EPA (1994)) .........................................................51

Tabela 4.2 - Resultados de ensaios de laboratório (modificado de Peterson et al. (2001)) 66

Tabela 4.3 - Características dos tanques bidimensionais e o tipo de injeção utilizado.

Tabela 5.1 - Valores de Pressão de entrada de ar (valores obtidos de USACE

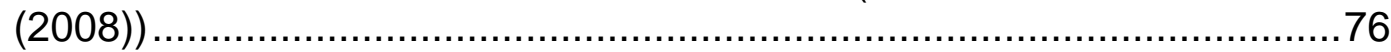

Tabela 6.1 - Dados da curva granulométrica.....................................................94

Tabela 6.2 - Resultado dos ensaios de índice de vazios máximo e mínimo (dados obtidos de Teixeira, 2008) .........................................................95

Tabela 6.3 - Sucções aplicadas com grau de saturação e saturação volumétrica correspondentes, dados da curva de retenção de água...........................96

Tabela 6.4 - Condutividade a água encontrada para cada índice de vazios. .........101

Tabela 6.5 - Dados da curva granulométrica da Areia do IPT .............................102

Tabela 6.6 - Resultado dos ensaios de índice de vazios máximo e mínimo Areia do

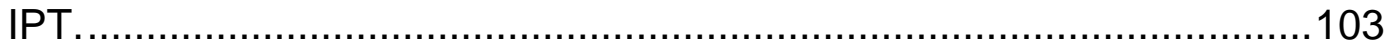

Tabela 6.7 - Condutividade a água encontrada para cada índice de vazios. ..........108

Tabela 7.1 - Descrição dos ensaios realizados com a Areia Osasco no modelo físico.

Tabela 7.2 - Dados da curva granulométrica da Areia Osasco depois dos ensaios com o tanque........................................................................123

Tabela 7.3 - Medidas de pressão de injeção de ar e vazão no segundo ensaio com a Areia Osasco ............................................................................124

Tabela 7.4 - Medidas de pressão de injeção de ar e vazão no terceiro ensaio com a Areia Osasco .......................................................................126

Tabela 7.5 - Medidas de pressão de injeção de ar e vazão no quarto ensaio com a AreiaOsasco 129

Tabela 7.6 - Descrição dos ensaios realizados com a Areia do IPT no modelo físico. 134

Tabela 7.7 - Medidas de pressão de injeção de ar e vazão no primeiro ensaio com a Areia do IPT.

Tabela 7.8 - Medidas de injeção de ar e vazão no segundo ensaio com a Areia do IPT. 138

Tabela 7.9 - Medidas de pressão de injeção e vazão no terceiro ensaio com a Areia do IPT.

Tabela 7.10 - Descrição dos ensaios realizados com as lentes de baixa permeabilidade no modelo físico. .....................................................141

Tabela 7.11 - Medidas de injeção de ar e a vazão, primeiro ensaio com as lentes de baixa permeabilidade. 


\section{Lista de Símbolos}
A
área da seção transversal
$b$
fator de Klinkenberg
c
fator de proporcionalidade
$C_{a}$
coeficiente de atividade do composto
$C_{e}$
concentração de equilíbrio do composto na mistura
$C_{e}{ }^{0}$
concentração de equilíbrio do composto considerando o mesmo puro
$D$ diâmetro médio dos poros.
$D_{10}$ diâmetro efetivo, que é o diâmetro que na curva granulométrica, corresponde à porcentagem que passa igual a $10 \%$
$D_{50} \quad$ diâmetro que na curva granulométrica, corresponde à porcentagem que passa igual a $50 \%$
$D_{60} \quad$ é o diâmetro abaixo do qual se situam em peso $60 \%$ das partículas
e
$e_{\text {máx }}$
$e_{\text {min }}$
$g$
$h_{1}$
$h_{c}$
$h_{s}$
$h_{w}$
$J$
K
$k$
$K_{0}$
$\mathrm{K}_{\mathrm{ar}}$
$k_{\text {gás }}$
$K_{h}$
$\mathrm{k}_{\text {int }}$
$K_{w}$
$L$
$\mathrm{m}$ índice de vazios
índice de vazios máximo
índice de vazios mínimo
aceleração da gravidade
profundidade de injeção
altura capilar
altura de solo acima do ponto de injeção
altura da coluna de água acima do ponto de injeção
fluxo de massa
condutividade
permeabilidade intrínseca
coeficiente de empuxo no repouso
condutividade ao ar
permeabilidade aparente ao ar
constante da Lei de Henry
coeficiente de permeabilidade intrínseca ou coeficiente de Klinkenberg condutividade hidráulica ou condutividade a água
comprimento do corpo de prova
parâmetro de simetria global da curva de retenção 
parâmetro de distribuição dos poros

$n$

porosidade

$n_{\text {gás }}$

número de moles do gás

$\mathrm{P}$

pressão

$P_{0}$

pressão absoluta

$P^{0}$

pressão de vapor do composto considerando o mesmo puro

$p_{a}$ pressão de ar

$P_{a}$ pressão parcial do contaminante

$P_{\text {atm }}$

pressão atmosférica

$p_{b}$

pressão de entrada de ar

$p_{c}$

pressão capilar

$P_{e}$

pressão absoluta de entrada do gás

$p_{h}$

pressão de água ou pressão hidrostática

$P_{m}$ pressão média absoluta entre as faces da amostra

$p_{\max }$ pressão máxima de injeção de ar sem que haja fratura no solo

$P_{s}$ pressão absoluta de saída de gás

$\mathrm{P}_{\mathrm{t}}$ carga total pressão de vapor

$Q$ vazão velocidade aparente do fluxo

$R$ constante dos gases perfeitos raio de curvatura na interface entre os dois fluidos

$R_{i}$ raio de influência

$\mathrm{S}$ saturação de água

$S_{a}$ saturação de ar

$\mathrm{S}_{\mathrm{c}}$ saturação completa

$\mathrm{S}_{\mathrm{e}}$ saturação efetiva

$\mathrm{S}_{\mathrm{r}} \quad$ saturação residual

$S_{w} \quad$ solubilidade em água

$T$ temperatura absoluta

$V_{a} \quad$ volume de ar

$V_{v} \quad$ volume de vazios

$X \quad$ fração molar do composto na mistura

$X_{a} \quad$ concentração do contaminante 
Z

$\mathrm{z}_{1}$

$\mathrm{z}_{2}$

$\alpha$

$Y_{f}$

$\gamma_{s}$

$Y_{\text {sat }}$

$\Delta h$

$\Delta \mathrm{m}$

$\Delta \mathrm{t}$

$\Delta x$

$\theta$

$\Theta$

$\theta_{\mathrm{r}}$

$\theta_{\mathrm{s}}$

$\lambda$

$\rho_{a r}$

$\rho_{f}$

$\rho_{w}$

$\sigma_{\text {horizontal }}$

$\sigma_{\text {vertical }}$

$\sigma_{g f}$

$\sigma_{\text {horizontal }}$

$\sigma_{\text {vertical }}$

$\tau$

$\varphi$

$\psi$

$\psi_{\mathrm{b}}$

$\omega$

$\mu_{a r}$

$\mu_{f}$

cota

cota de entrada

cota de saída

inverso da pressão de entrada de ar

peso específico do fluido

peso específico do solo

peso específico saturado

diferença de altura

variação de massa

unidade de tempo

comprimento da coluna

teor de umidade volumétrica

teor de umidade volumétrica adimensional

teor de umidade volumétrica residual

teor de umidade volumétrica equivalente a saturação completa

índice de distribuição dos poros

densidade do ar

densidade do fluido

densidade da água

tensão efetiva horizontal

tensão efetiva vertical

tensão interfacial entre o gás e o fluido

tensão total horizontal

tensão total vertical

caminho médio livre

ângulo de atrito interno do solo

sucção

pressão de entrada de ar

ângulo de contato entre os fluidos

viscosidade dinâmica do ar

viscosidade dinâmica do fluido 


\section{Lista de Abreviaturas}

BTEX Benzeno, tolueno, etilbenzeno e xileno

CNU Coeficiente de não uniformidade

DNAPL Compostos imiscíveis na forma liquida mais densos que a água (Dense Non-Aqueous Phase Liquid)

ERT Tomografia de resistência elétrica (Electrical Resistence Tomography)

LMS Laboratório de Mecânica dos Solos

LNAPL Compostos imiscíveis na forma liquida menos densos que a água (Ligth Non-Aqueous Phase Liquid)

MTBE Éter metil terbutílico (Methyl tertiary butyl ether)

NAPL Compostos imiscíveis na forma liquida, ou mais conhecido como fase livre (Non-Aqueous Phase Liquid)

OD Oxigênio dissolvido

SVE Extração de vapores

TDR Refletômetria no domínio do tempo (Time Domain Reflectometry)

VOCs Compostos Orgânicos Voláteis (Volatile Organic Compounds) 


\section{Capítulo 1}

\section{Considerações Iniciais}

Diversas técnicas de remediação de solos contaminados por derivados de petróleo são utilizadas, tais como: aeração mecânica do solo, extração de vapores (SVE), injeção de ar, bombeamento e tratamento da água subterrânea, dessorção térmica, biorremediação entre outras. Em alguns casos podem ser utilizadas mais de uma técnica, visando melhorar a eficiência na descontaminação. Na técnica de injeção de ar é comum fazer associação com a técnica de SVE, mas também é possível associá-la com outras.

Para se ter uma boa eficiência no método de injeção de ar é preciso delimitar a área do solo em que ocorre o fluxo de ar. Essa área recebe o nome de zona de influência e é afetada pela formação e estrutura do solo, variação no tipo de solo, tamanho médios dos grãos, tamanho dos poros, permeabilidade, pressão e profundidade de injeção entre outros. Para se fazer um uso adequado do método é preciso entender a forma dos caminhos do fluxo de ar (canais ou bolhas), o modo como ele se movimenta pelo solo, e o tamanho e a geometria da zona de influência.

Estudos teóricos e experimentais da zona de influência em solos heterogêneos são necessários para um bom entendimento do método, do espaçamento dos poços e da profundidade de injeção. Vários autores, tais como: (BAKER e BENSON, 2007; BROOKS, WISE e ANNABLE, 1999; ELDER e BENSON, 1999; Jl et al, 1993;) utilizaram bolinhas de vidro visando caracterizar o comportamento do fluxo em um solo granular. Já autores como: (CHAO, ONG e HUANG, 2008; PETERSON et. al. 1999, 2000 e 2001, REDDY e ADAMS, 2001) realizaram ensaios em laboratório com solos naturais.

\subsection{Objetivos}

O presente estudo apresenta uma revisão bibliográfica sobre a técnica de injeção de ar descrevendo os diversos aspectos que influenciam a eficiência do método. $\mathrm{O}$ 
objetivo do trabalho é apresentar o resultado de experimentos de laboratório, dentre eles ensaio de permeabilidade ao ar e ensaios com um modelo físico de modo a identificar os parâmetros necessários para a primeira avaliação de eficiência do método de injeção de ar; tais como: pressão de entrada de ar e condutividade ao ar e a água dos materiais.

Neste trabalho foram utilizadas areias e silte areno-argiloso em ensaios bidimensionais, visando representar melhor o comportamento que ocorre em campo. Os ensaios bidimensionais têm por finalidade a visualização da zona de influência nos solos em estudo. O diferencial deste trabalho é o método de visualização, que foi feito apenas através da parede de acrílico do tanque, quando o ar penetrava no solo era possível ver a dessaturação do solo e descrever a zona de influência formada.

\subsection{Estrutura do texto}

Capítulo 2: explica a técnica de descontaminação através da injeção de ar e seus processos de remediação, bem como as características dos contaminantes removidos durante o método.

Capítulo 3: trata dos aspectos de campo relacionados ao método de injeção de ar, tais como: pressão de injeção, profundidade de injeção, vazão, freqüência de injeção, raios de influência entre outros. E também são apresentados neste capítulo a descrição do comportamento do fluxo e seus estágios (expansão, colapso e equilíbrio); a variação do nível de água durante as fases de expansão e colapso; os tipos de poços de injeção e sua instalação.

Capítulo 4: apresenta o comportamento do fluxo em modelo físico. Descreve os resultados encontrados por diversos autores para a zona de influência em tanques bidimensionais. Também expõe a influência das condições do solo na injeção de ar, e os tipos de injeção utilizados em laboratório (poço ou difusor). 
Capítulo 5: expõe os fundamentos teóricos relacionados ao método de injeção de ar, descrevendo o desenvolvimento da Lei de Darcy, a pressão capilar e o transporte e transferência de massa.

Capítulo 6: mostra os ensaios de laboratório realizados para as areias e para o silte areno-argiloso e seus resultados. A curva de retenção e o ensaio de permeabilidade ao ar tiveram uma maior ênfase neste capítulo devido a sua importância para a técnica de injeção de ar.

Capítulo 7: descreve os ensaios de laboratório realizados em um tanque transparente e bidimensional; e também apresenta seus resultados em ensaios com uma areia natural denominada Areia Osasco, uma areia comercial (Areia do IPT) e essa com lentes de baixa permeabilidade feitas com um solo siltoso. Também é descrita a montagem do tanque bem como do difusor, usado na injeção de ar, instalado na base do mesmo.

Capítulo 8: apresenta as principais conclusões obtidas com esse estudo e as recomendações para trabalhos futuros.

Capítulo 9: mostra às referências bibliográficas utilizadas neste trabalho. 


\section{Capítulo 2}

\section{Introdução}

\subsection{Contaminantes derivados do petróleo}

Contaminações com derivados de petróleo são muito freqüentes em todos os países. Os compostos mais comumente encontrados nas contaminações subterrâneas são o óleo diesel e a gasolina, sendo a gasolina mais facilmente removida com a utilização do método de injeção de ar. A gasolina possui cerca de 20 substâncias, sendo que aquelas com maior impacto ambiental são os BTEX (benzeno, tolueno, etilbenzeno e xileno) devido a sua alta solubilidade, que faz com que a gasolina tenha uma maior mobilidade em meio aquoso. Na gasolina brasileira é adicionado também etanol, componente que pode modificar algumas propriedades da gasolina, como: a solubilidade, a mobilidade e a biodegradação.

$\mathrm{Na}$ composição da gasolina encontram-se hidrocarbonetos leves contendo de 4 a 12 carbonos em cadeias lineares e compostos aromáticos. O baixo peso molecular dos compostos da gasolina resulta em baixa viscosidade, alta volatilidade e moderada solubilidade em água. Os compostos aromáticos são representados principalmente pelos BTEX que possuem de 6 a 8 carbonos. Quanto maior o número de carbonos que formam uma cadeia em um hidrocarboneto, menor sua volatilidade; é por isso que, nas contaminações por gasolina, os compostos com 4 a 5 carbonos são volatilizados mais rápido que os demais. E também, quanto maior a cadeia de carbonos, menor a mobilidade e maior a facilidade do composto ficar adsorvido à matéria orgânica.

A migração e dispersão dos contaminantes derivados de petróleo dependem de propriedades do solo, tais como a porosidade e a permeabilidade. A porosidade tem relação com a capacidade do solo em reter o contaminante e a permeabilidade é a responsável pelo transporte desse fluido. As propriedades do fluido que influenciam a movimentação do contaminante são: densidade, viscosidade e tensão superficial. A densidade está relacionada com a tendência de a fase livre acumular ou não 
Capítulo 2 - Introdução

acima do nível d'água, sendo que os contaminantes de baixa densidade é que acumulam acima do lençol freático. A viscosidade é inversamente proporcional a mobilidade do fluido, quanto menor a viscosidade maior a mobilidade. E é por causa da tensão interfacial que os solos finos retêm mais fase livre do que os solos grossos.

Geralmente, quando ocorre um vazamento de produtos derivados do petróleo no solo, os contaminantes tendem a percolar pelo solo até atingir o nível de água. Isso ocorre se o volume do vazamento for suficiente para superar a capacidade de retenção do solo.

Como os compostos da gasolina apresentam boa mobilidade, quando ocorre uma contaminação há uma rápida infiltração no solo atingindo a água subterrânea onde os compostos da gasolina não se misturam completamente, formando a então chamada fase livre.

O acúmulo de contaminantes imiscíveis em água na forma líquida é chamado de fase livre ou Non-Aqueous Phase Liquid (NAPL) classificados ainda em:

$>$ Ligth Non-Aqueous Phase Liquid (LNAPL): se o contaminante for menos denso do que a água

$>$ Dense Non-Aqueous Phase Liquid (DNAPL): se o contaminante for mais denso que a água.

Na Figura 2.1 pode ser observada a pluma de contaminação e a fase livre em (a) LNAPL e em (b) DNAPL. Os LNAPLs sobem acima da zona saturada e são transportados verticalmente devido a flutuações sazonais do nível de água. Já os DNAPs freqüentemente são encontrados nos solos abaixo do nível de água. 
Capítulo 2 - Introdução

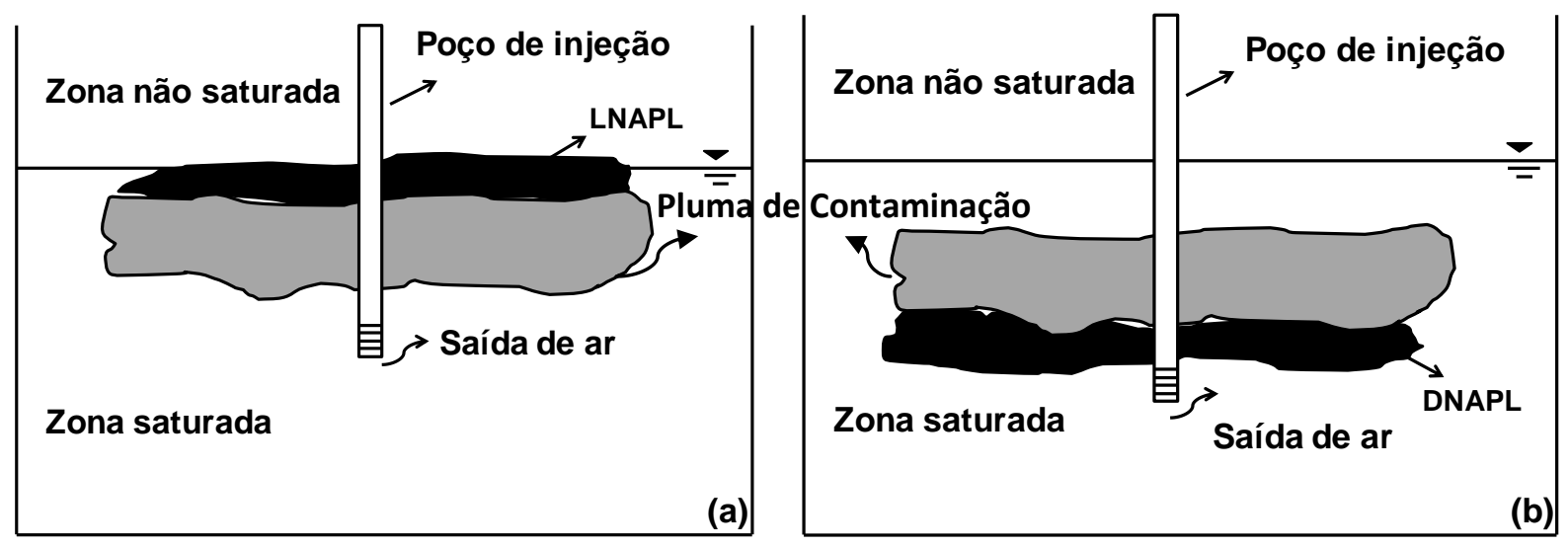

Figura 2.1 - Localização da pluma de contaminação em (a) pode ser visto o LNAPL e em (b) o DNAPL

Os contaminantes derivados de petróleo podem ser encontrados no solo em quatro condições: 1) vapor, 2) livre (hidrocarboneto líquido), 3) residual (preso por capilaridade ou adsorvido no solo) e 4) dissolvida (pode se encontrar tanto na zona saturada como na zona não saturada). A técnica de injeção de ar permite a remoção dos contaminantes na fase 4 e eventualmente na fase 3 . As quatro fases apresentadas acima podem ser visualizadas nas Figura 2.2.

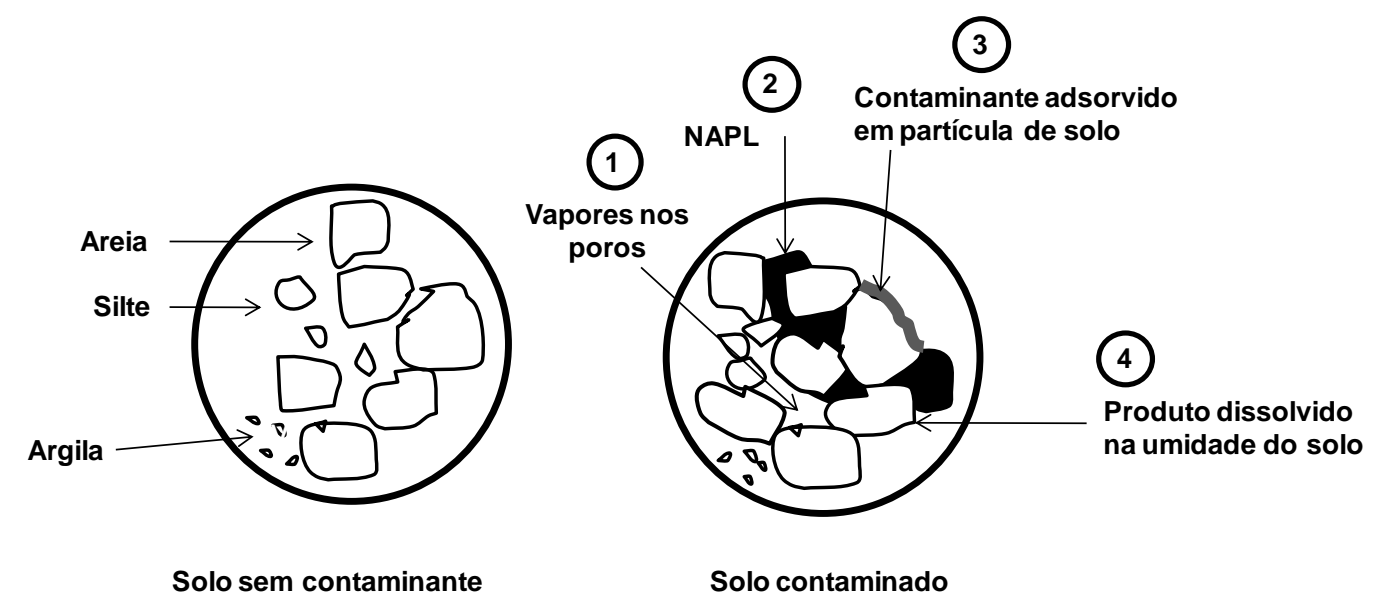

Figura 2.2 - Condições do contaminante no solo (modificado de Suthersan, 1997)

\subsubsection{Características dos contaminantes}

As características dos contaminantes que afetam a transferência de massa são pressão de vapor $\left(P_{\text {vapor }}\right)$, solubilidade em água $\left(\mathrm{S}_{\mathrm{w}}\right)$, constante da Lei de Henry $\left(K_{h}\right)$, biodegradabilidade e coeficiente de difusão na água. O método de injeção de ar é 
Capítulo 2 - Introdução

mais eficiente em solos com elevada condutividade hidráulica e contaminantes com baixa solubilidade e de fácil volatilização.

Segundo Suthersan (1997) contaminantes com elevadas pressões de vapor geralmente passam da fase dissolvida para a de vapor mais facilmente, os contaminantes com pressão de vapor maior do que $0,5 \mathrm{mmHg}(0,07 \mathrm{kPa})$ são considerados de fácil remoção pela injeção de ar.

A pressão de vapor depende da temperatura e é definida como a pressão exercida por um vapor quando este está em equilíbrio com o líquido que lhe deu origem. Quanto maior for a sua pressão de vapor mais volátil será o líquido. Para a gasolina pode-se expressar a pressão de vapor como sendo:

$$
P_{a}=X C_{a} P^{0}
$$

$P_{a}$ - pressão parcial de vapor do contaminante (composto);

$X$ - Fração molar do composto na mistura;

$C_{a}$ - Coeficiente de atividade do composto;

$P^{0}$ - Pressão de vapor do composto considerando o mesmo puro.

A solubilidade é a capacidade de uma substância se dissolver em outra em uma determinada temperatura; existe um máximo de soluto que pode se dissolver em certa quantidade de solvente, sendo expressa normalmente em miligramas por litro (mg/l) ou microgramas por litro $(\mu \mathrm{g} / \mathrm{l})$. Para misturas como a gasolina, a solubilidade depende da fração molar de cada composto individual na mistura segundo a equação (1.2):

$$
C_{e}=X C_{a} C_{e}^{0}
$$

$C_{e}$ - Concentração de equilíbrio do composto na mistura;

$X$ - Fração molar do composto na mistura;

$C_{a}$ - Coeficiente de atividade do composto;

$\mathrm{C}_{\mathrm{e}}{ }^{0}$ - Concentração de equilíbrio do composto considerando o mesmo puro. 
A constante da Lei de Henry quantifica a tendência de o contaminante dissolvido passar para a fase de vapor. Quando gases são dissolvidos em líquidos, a constante de equilíbrio é expressa na forma da constante da Lei de Henry, que formula que a massa molar de um gás dissolvido em um dado volume de líquido é proporcional a pressão parcial do gás; por isso para gases ideais e em equilíbrio com a solução tem-se que:

$$
K_{h}=\frac{X_{a}}{P_{a}}
$$

$K_{h}$ - Constante da Lei de Henry

$P_{a}$ - pressão parcial de vapor do contaminante (atm);

$X_{a}$ - concentração do contaminante (fração molar).

A injeção de ar é mais eficaz na remoção de contaminantes com constantes de Henry elevadas, porque o contaminante é prontamente retirado da água. Quanto maior o valor da constante da Lei de Henry mais solúvel é o gás. Contaminantes como benzeno, tolueno, xileno, etilbenzeno, tricloroeteno e tetracloroeteno são de fácil remoção devido à sua elevada constante de Henry como pode ser visto na Tabela 2.1. A injeção de ar é pouco usada na descontaminação de solos com diesel e querosene.

Tabela 2.1 - Contaminantes e suas características (valores de pressão de vapor e constante da Lei de Henry retirados de Suthersan (1997))

\begin{tabular}{lccc}
\hline \multicolumn{1}{c}{ Contaminantes } & $\begin{array}{c}\boldsymbol{K}_{\boldsymbol{h}} \\
(\text { atm.m3/mol })\end{array}$ & $\begin{array}{c}\boldsymbol{P}_{\text {vapor }} \\
(\mathrm{mmHg})\end{array}$ & $\begin{array}{c}\boldsymbol{S}_{\boldsymbol{w}} \\
(\mu \mathrm{g} / \mathrm{l})\end{array}$ \\
\hline Benzeno $(\mathrm{C} 6 \mathrm{H} 6)$ & $5,48 \times 10^{-3}$ & 95,2 & $1,75 \times 10^{6}$ \\
Tolueno $(\mathrm{C} 7 \mathrm{H} 8)$ & $6,6 \times 10^{-3}$ & 28,4 & $5,35 \times 10^{5}$ \\
Xileno $(\mathrm{C} 8 \mathrm{H} 10)$ & $5,1 \times 10^{-3}$ & 6,6 & $1,98 \times 10^{5}$ \\
Etilbenzeno $(\mathrm{C} 8 \mathrm{H} 10)$ & $8,68 \times 10^{-3}$ & 9,5 & $1,52 \times 10^{5}$ \\
Tricloroetileno $(\mathrm{C} 2 \mathrm{HCl} 3)$ & $10 \times 10^{-3}$ & 60 & $1,28 \times 10^{6}$ \\
Tetracloroeteno $(\mathrm{C} 2 \mathrm{Cl} 4)$ & $8,3 \times 10^{-3}$ & 14,3 & $1,60 \times 10^{5}$ \\
\hline
\end{tabular}


A Lei de Henry só é válida quando a massa de contaminantes dissolvidos atinge o equilíbrio com a interface ar-água; o tempo que o ar permanece nos canais é muito pequeno devido à alta velocidade do ar nesses caminhos curtos (SUTHERSAN, 1997). É por esse motivo que o equilíbrio nem sempre é alcançado, e é devido a isso que alguns autores consideram que a constante da Lei de Henry não tem muita influência na remoção dos contaminantes do solo, sendo a alta pressão de vapor dos contaminantes a principal responsável pela eficiência da remediação.

Modelagens matemáticas feitas por Johnson (1998) mostraram que a taxa de remoção durante o processo de volatilização não depende das propriedades físicoquímicas dos contaminantes tais como pressão de vapor e a constante da Lei de Henry. Isso quer dizer que os produtos químicos que tenham baixas constantes da Lei de Henry, mas alta solubilidade (como MTBE, combustível oxigenado), podem apresentar taxas de remoção aceitáveis. É por esse motivo que a eficiência sempre decresce com a diminuição da solubilidade para contaminantes não degradáveis; é por isso que alguns autores dizem que a propriedade química que mais afeta o desempenho da injeção de ar é a solubilidade.

Segundo Marley, Hazerbrouck e Walsh, (1992) a técnica de injeção de ar pode ser usada em compostos orgânicos voláteis (VOC) de gasolina ou DNAPLs e é eficiente na remoção de contaminantes adsorvidos no solo, em fase livre e dissolvidos na água subterrânea.

Devido à limitada solubilidade e volatilidade dos VOCs em condições ambientais, contaminantes orgânicos geralmente penetram no solo em fase líquida, imiscível com o ar e a água (MARULANDA, 2001). Uma parte desses contaminantes é transportada pela água subterrânea, criando plumas de contaminação que rapidamente migram tanto verticalmente como horizontalmente.

A técnica de injeção de ar não é eficiente no tratamento de produtos químicos inorgânicos ou sais, e também para contaminantes que não são nem de fácil volatilização e nem de fácil biodegradação. Esse método é mais rápido e mais barato para contaminantes dissolvidos na água subterrânea do que para contaminantes presentes no solo em fase livre. 


\subsection{Remediação pelo método de injeção de ar}

Segundo Gudemann e Hiller (1988) apud USACE (2008) uma das primeiras vezes que o método de injeção de ar foi utilizado foi na Alemanha na década de 1980, para aumentar a remediação de água subterrânea contaminada com organoclorados. Atualmente essa técnica é mais usada para a descontaminação de solos contaminados com gasolina ou combustíveis derivados do petróleo.

A injeção de ar (air sparging) é um método in-situ utilizado na descontaminação de solos e águas subterrâneas contaminados com (VOCs), dissolvidos na água subterrânea. A injeção de ar ou outros gases é feita, através de poços, abaixo do nível de água do solo e em aqüíferos não confinados. A passagem do ar injetado; da zona saturada para a zona não saturada; faz com que os VOCs sejam removidos da água subterrânea e da franja capilar. Além da injeção de ar, que é o gás mais utilizado, pode-se aplicar oxigênio, que acelera o processo de biodegradação. $O$ ar comprimido é aplicado em pressões e volumes controlados. Podem ser usados tanto poços horizontais como verticais para a injeção do ar, e são usados um ou mais poços de injeção. $O$ ar passa pela água contaminada e os contaminantes volatilizados entram em contato com esse ar em movimento e são levados até a zona não saturada onde podem ser removidos com auxílio do método SVE (extração de vapores).

O modelo do sistema de injeção de ar associado com o método SVE está representado na Figura 2.3, na qual também é possível notar os chamados ramos mortos, que são canais de ar que param de crescer antes de chegar à zona não saturada formando assim canais de ar incompletos que são ineficientes na remoção dos contaminantes. Segundo Johnson et. al. (1993) geralmente a taxa de remoção de ar usada pelo SVE é maior que a taxa de injeção de ar usada no método em estudo. Isto é feito para garantir que não ocorra migração dos contaminantes para áreas não afetadas. 


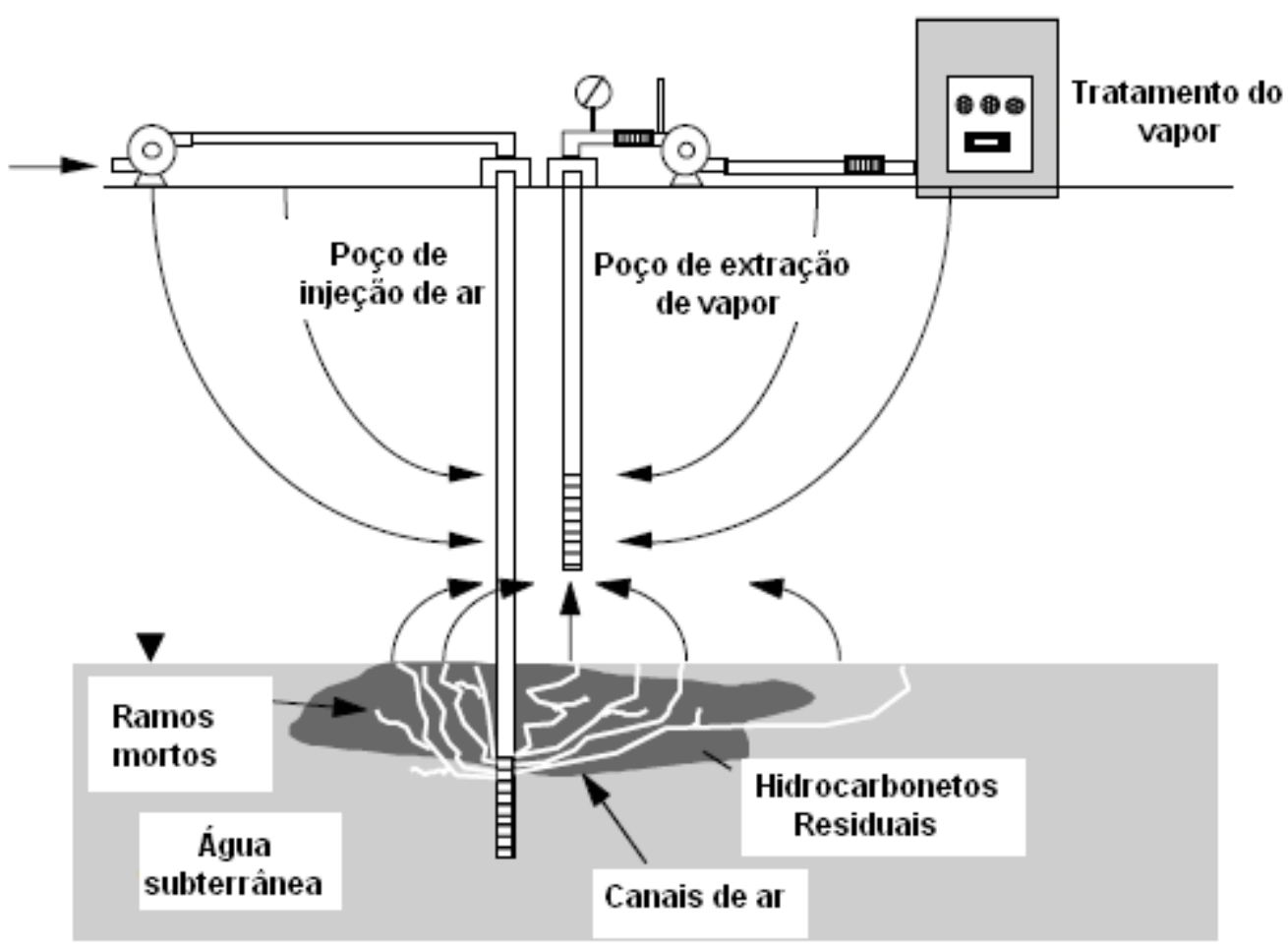

Figura 2.3 - Método de injeção de ar associado com o método de extração de vapores (SVE) (adaptado de Johnson (1998))

O método de extração de vapores (SVE) é usado em conjunto com a injeção de ar para remover os vapores dos contaminantes da zona não saturada, liberados durante o processo de injeção. Essa extração é feita para minimizar a possível migração dos contaminantes para regiões onde haja construções ou tubulações. Às vezes o uso do método de extração de vapores não é necessário, mas isso só pode ser feito em regiões remotas onde as taxas de emissão fiquem em níveis aceitáveis ou em casos onde a taxa de injeção de ar for muito baixa e os vapores dos contaminantes sejam degradados logo que atinjam a zona insaturada. Assim como na injeção de ar, no método de extração de vapores podem ser utilizados mais de um poço de extração, como o esquema mostrado na Figura 2.4. 


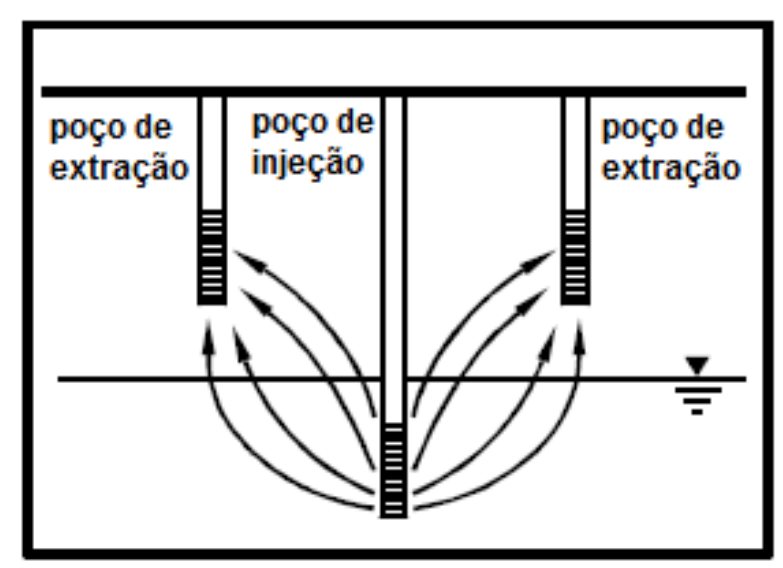

Figura 2.4 - Método de injeção de ar associado com o método de extração de vapores (SVE) (adaptado de EPA (1994))

O ar injetado na zona saturada sobe formando caminhos em forma de bolhas ou em forma de canais contínuos de ar como será visto mais adiante. Esses caminhos formados pelo ar dependem da pressão e da taxa de fluxo (vazão) com que o ar é injetado e da profundidade de injeção, mas, segundo Johnson et al. (1993), o fator dominante é a estrutura e estratificação do solo na zona saturada.

A injeção de ar faz com que a água saia dos poros na região saturada dando lugar ao ar em função da pressão que é aplicada. A saída de água depende da capacidade do solo de reter água em seus poros. Quanto maior for essa capacidade de retenção mais difícil é para o ar deslocar a água para permitir sua passagem pelos poros, fazendo com que a injeção não seja suficiente.

Para se determinar o número de poços de injeção, sua localização e as vazões aplicadas geralmente são feitos ensaios de pequeno porte (teste piloto) no local onde o método será aplicado. Não deve haver nenhum contaminante na fase livre na zona de injeção de ar, pois durante a injeção pode ocorrer uma movimentação dessa fase para áreas não contaminadas.

Segundo a CETESB (1999) a injeção de ar no solo causa a transferência de massa através da extração dos contaminantes dissolvidos, da volatilização do mesmo abaixo do nível d'água na fase adsorvida e da biodegradação dos VOC's adsorvidos e dissolvidos devido ao aumento dos níveis de oxigênio dissolvido. 
Com base na literatura as vantagens oferecidas pela injeção de ar são:

- A remediação é acelerada em contaminantes adsorvidos ao solo e contaminantes da franja capilar;

- É um método relativamente fácil de implantar no campo;

- Tem uma boa relação custo-benefício;

- Tempo de tratamento curto.

A injeção de ar é usada para (1) remediar plumas de contaminantes dissolvidos; (2) criar uma barreira na migração da pluma de contaminantes dissolvidos, por exemplo, plumas de clorados dissolvidos e MTBE. Quando o método de injeção é usado como barreira na migração de contaminantes, os poços de injeção são geralmente colocados em uma linha (ou várias linhas) perpendicularmente a direção do fluxo da água subterrânea, com o objetivo de criar uma zona de tratamento para prevenir a migração da pluma de contaminantes dissolvidos.

Para que a injeção de ar seja eficiente o solo deve ser o mais homogêneo possível. A eficiência depende de vários outros fatores além da homogeneidade que serão discutidos adiante. Porém, deve-se destacar que nenhuma técnica de descontaminação de solos consegue realizar todos os objetivos de uma limpeza completa do local.

Os fatores mais significativos quanto ao desempenho da injeção de ar segundo Leeson et al. (2002) são:

- A distribuição de ar na zona de tratamento, ou seja, o formato da zona de influência;

- A distribuição (localização e concentração) de contaminantes em relação à distribuição de ar, e

- As características dos contaminantes (composição e propriedades químicas).

Segundo Lesson et. al. (2002) aquíferos profundos, aquíferos com altas estratificações e aquíferos em que o solo se torna mais fino com a profundidade a técnica de injeção de ar pode ser utilizada, porém é necessário um cuidado no monitoramento, pois pode haver dispersão do poluente em certos casos. 
A injeção de ar não é um método de descontaminação indicado para solos argilosos, dada a baixa permeabilidade e a alta capacidade de retenção de água, fazendo com que a pressão de entrada de ar também seja alta, o que acaba inviabilizando o processo devido à necessidade de altas pressões de injeção. $O$ método de injeção de ar é indicado para aqüíferos que possuem profundidades médias a rasas (menos que $15 \mathrm{~m}$ (50ft) abaixo da superfície) e solos arenosos ou siltosos.

Segundo Leeson et al. (2002) o tempo de funcionamento da injeção de ar deve ser monitorado, senão alguns sistemas irão operar mais do que o necessário e outros podem terminar antes de atingir a máxima capacidade de remediação. Ambos os casos têm implicações econômicas, pois o custo aumenta com o tempo de operação. Para aprimorar o sistema de injeção de ar é preciso ter procedimentos que avaliem o sistema em tempo real.

Segundo EPA (1994) o custo de remediação aumenta com a profundidade do nível d'água.

\subsection{Mecanismos de remoção}

A injeção de ar depende de dois processos básicos de remoção dos contaminantes: volatilização e biodegradação. Os dois mecanismos são controlados pelos mesmos fatores; sendo acelerados com o aumento da temperatura, pois há uma diminuição da viscosidade com o aumento da temperatura, facilitando assim a mobilidade do fluido. Segundo Mickelson (2003), quando o ar se encontra abaixo da temperatura ambiente do aqüífero ele não deve ser injetado.

A remoção dos contaminantes depende de suas propriedades químicas e de sua distribuição, duração da injeção e das propriedades do solo. O processo de volatilização predomina enquanto o ar está sendo injetado no solo. Quando a injeção cessa o processo predominante é a biodegradação. 


\subsubsection{Volatilização}

Segundo Johnson (1998) a volatilização é o primeiro mecanismo de remoção da injeção de ar, principalmente em locais onde a concentração de contaminantes dissolvidos é maior do que $1 \mathrm{ppm}$.

A eficiência da injeção de ar é governada pelo contato interfacial entre água e ar e/ou NAPL e ar e também pelo tamanho da pluma de contaminação (BAKER e BENSON, 1996). A remoção inicial ocorre mais rapidamente porque os contaminantes perto dos canais de ar são volatilizados, depois a remoção é mais lenta porque os contaminantes se difundem pelo canal de ar antes de serem removidos. A Figura 2.5 representa um gânglio de NAPL se dissolvendo e se difundindo pelos canais de ar. Quando o NAPL está em contato direto com o canal de ar a volatilização e remoção é mais rápida, pois depende apenas do processo de evaporação. Depois o processo é mais demorado devido ao transporte de massa ser regido pela difusão que é um processo lento; e que consiste no fluxo do contaminante da região de maior para a de menor concentração.

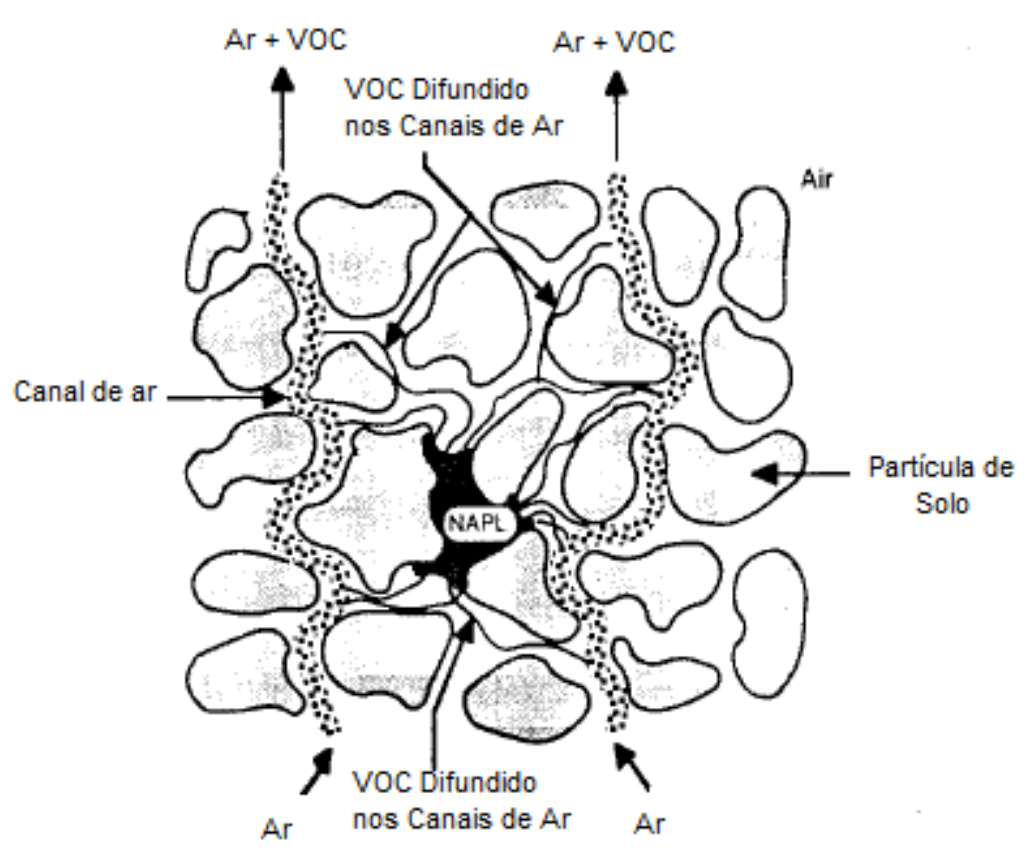

Figura 2.5 - NAPL dissolvendo e difundindo pelos canais de ar (adaptada de Baker e Benson (1996)) 
Segundo Suthersan (1997) a volatilização depende da pressão de vapor do contaminante (maior do que 0,5 a $1,0 \mathrm{mmHg}$ ), por isso a maioria dos VOCs é removida facilmente por esse mecanismo.

A eficiência do sistema de injeção de ar no processo de volatilização depende principalmente da natureza do fluxo de ar nos poros saturados do solo, propriedades químicas dos VOCs e dos mecanismos de transferência de massa (CHAO, ONG, HUANG, 2008). Quanto maior o volume de solo saturado alcançado pela injeção de ar menor será o tempo de volatilização e maior a eficiência.

Os contaminantes que estão na fase de vapor são mais voláteis e podem atingir grandes distâncias através de caminhos preferenciais como, por exemplo, fraturas, juntas e lentes de areia.

\subsubsection{Biodegradação}

A introdução de ar no solo aumenta o oxigênio dissolvido, estimulando assim a biodegradação. $O$ processo de transferência de oxigênio está relacionado com o tamanho da pluma, o diâmetro dos canais, e a vazão de ar. A transferência de oxigênio é limitada pelo processo de difusão. Que ocorre mesmo na ausência de movimento hidráulico, pois é um processo de fluxo de partículas de soluto da região de maior para a de menor concentração.

A biodegradação de qualquer composto em condições aeróbias depende do $\mathrm{pH}$ e temperatura do ambiente. A injeção de ar é capaz de remediar solos com contaminantes não voláteis desde que sejam biodegradáveis. Alguns VOCs são de fácil biodegradação (benzeno, tolueno, acetona, etc) e alguns não (tricloroeteno e tetracloroeteno).

Segundo Suthersan (1997) o comprimento dos caminhos de difusão para o transporte de oxigênio na água subterrânea é definido pelas distâncias entre os canais de ar. Com isso pode-se notar que, quanto mais afastados os canais se encontram, mais difícil se torna a biodegradação aeróbia, pois a difusão não é suficiente para transportar o oxigênio pelo aqǘf́ro. 
Se o objetivo principal da remediação é a biodegradação e não a volatilização o volume de ar não precisa ser o mesmo requerido quando o mecanismo de remoção principal é a volatilização, ele pode ser menor, é por isso que a vazão necessária para este tipo de remediação é menor.

Em estudos numéricos realizados por Johnson (1998), notou-se que a biodegradação aeróbia ocorre somente aumentando o desempenho relativo da volatilização quando a concentração dos contaminantes dissolvidos for menor do que $1 \mathrm{mg} / \mathrm{L}$, independente de outros parâmetros químicos.

O termo "biosparging" é freqüentemente usado para se referir ao sistema de injeção de ar sem o uso do método de SVE, mas alguns autores usam esse termo quando a biodegradação é o mecanismo de remoção principal. Segundo Leeson et al., (2002) o objetivo principal do "biosparging" é reduzir a taxa de volatilização até um nível em que o sistema de SVE não seja necessário, embora as baixas vazões utilizadas no "biosparging" sejam ineficientes no tratamento de lugares com alta concentração de contaminantes. 


\section{Capítulo 3}

\section{Características da Técnica de Injeção de ar}

\subsection{Sistema de Variáveis}

$\mathrm{Na}$ injeção de ar o sistema de variáveis inclui a pressão de injeção, a vazão (taxa de fluxo), injeção de ar por pulso, e a profundidade de injeção. Essas variáveis afetam a saturação de ar e o volume de solo que é tratado. A pressão e a vazão de injeção estão relacionadas a propriedades do solo como a permeabilidade intrínseca e a capacidade de retenção de água do solo.

A saturação de $\operatorname{ar}\left(S_{a}\right)$ é definida como o volume de $\operatorname{ar}\left(V_{a r}\right)$ pelo volume de vazios $\left(V_{v}\right)$.

$$
S_{a}=\frac{V_{a r}}{V_{v}}
$$

\subsubsection{Pressão de injeção}

A pressão de injeção depende da profundidade dos poços e dos aspectos geológicogeotécnicos do local. Segundo Ahlfeld, Dahmani e Ji (1994) um aumento na pressão de injeção causa um aumento no tamanho dos canais e também ocorre a formação de novos canais. Isto faz com que a descontaminação seja mais rápida, mas a pressão de injeção não pode ser muito elevada, pois pode causar a ruptura do solo.

A pressão mínima para que 0 ar comece a penetrar no solo é conhecida como pressão inicial ou pressão de entrada de $\operatorname{ar}\left(p_{b}\right)$; e que, segundo Baker e Benson (2007), é determinada, experimentalmente em laboratório através de modelos bidimensionais, aumentando a pressão até que se possam ver os canais de ar no solo. 
Para que o ar injetado entre no aqüífero é necessário que a pressão de entrada de $\operatorname{ar}\left(p_{b}\right)$ seja maior que a pressão hidrostática $\left(p_{\mathrm{h}}\right)$. A pressão de entrada de $\operatorname{ar}\left(p_{\mathrm{b}}\right)$ é a mínima pressão capilar (pressão de ar menos pressão de água) necessária para induzir o fluxo de ar na zona saturada; isso será visto novamente mais adiante de uma maneira mais formal.

O fluxo de ar pelo solo saturado somente ocorre quando a pressão de entrada de ar é excedida no ponto de injeção. Quando a pressão de entrada de ar é superada, o ar injetado desloca a água ao longo dos caminhos de menor resistência. Esses caminhos, ou canais, são resultados da diferença de pressão de entrada de ar no solo causados por micro ou macro heterogeneidades.

Segundo Marulanda (2001) as pressões de injeção máxima e mínima devem seguir as seguintes formulações:

A mínima pressão de injeção precisa ser suficientemente alta para superar a soma da pressão hidrostática $\left(p_{\mathrm{h}}\right)$ com a pressão capilar $\left(p_{\mathrm{c}}\right)$. A mínima pressão de injeção de ar ou pressão de entrada de ar é dada por $\left(p_{\mathrm{b}}\right)$ em kPa:

$$
\begin{gathered}
p_{b}=p_{h}+p_{c} \\
p_{h}=\gamma_{f} h_{w} \\
p_{b}=\gamma_{f} h_{w}+\frac{4 \sigma_{g f} \cos \omega}{D}
\end{gathered}
$$

$\mathrm{Y}_{f}$ - peso específico do fluido, que neste caso, é a água $\left(\mathrm{kg} / \mathrm{m}^{3}\right)$,

$g$ - aceleração da gravidade $\left(9,8 \mathrm{~m} / \mathrm{s}^{2}\right)$,

$h_{w}$ - altura da coluna de água acima do ponto de injeção $(\mathrm{m})$,

$\sigma_{g f}$ - tensão interfacial entre o gás e o fluido,

$\omega$ - ângulo de contato entre os fluidos,

$D$ - diâmetro médio dos poros.

A equação (3.4), embora não seja precisa pode ser usada para saber o efeito do tamanho dos poros e assim do tipo de solo. Pode-se também fazer uma analogia com o tamanho dos grãos. 
Para solos granulares, que não possuem coesão, a pressão máxima ( $\left.p_{\text {máx }}\right)$ é dada pelo valor mínimo entre a tensão vertical e a horizontal:

$$
\begin{gathered}
p_{\text {máx }}=\min \left(\sigma_{\text {vertical }}, \sigma_{\text {horizontal }}\right) \\
\sigma_{\text {vertical }}^{\prime}=\gamma_{\text {sat }} * h_{s}-\gamma_{f} * h_{w} \\
\sigma_{\text {horizontal }}^{\prime}=K_{0} * \sigma_{\text {vertical }}^{\prime} \\
K_{0}=1-\sin \varphi
\end{gathered}
$$

Ysat - peso específico do solo saturado;

$\mathrm{h}_{\mathrm{s}}$ - altura de solo acima do ponto de injeção;

$\mathrm{K}_{0}$ - coeficiente de empuxo no repouso;

$\varphi$ - ângulo de atrito interno do solo.

Segundo Leeson et al., (2002) a pressão de operação do método é determinada pela profundidade dos poços de injeção abaixo do nível de água e da permeabilidade do aqüífero. Durante o começo da injeção de ar a pressão da água subterrânea aumenta porque 0 ar está sendo empurrado para dentro do aqüífero mais rápido do que a água pode se mover para fora, para dar lugar ao ar. Este aumento de pressão de água pode causar problemas de estabilidade de taludes em alguns locais (e.g. Marinho; Moretti, 2008)

Naval Facilities Engineering Service Center (2001) apud Aivalioti e Gidarakos (2008), afirmam que, a máxima pressão que pode ser aplicada no aqüífero sem causar fratura do solo ou algum outro problema é:

$$
p_{\text {máx }}=h_{1} \gamma_{s}(1-n) 9,8+h_{w} \gamma_{s} 9,8
$$

$h_{1}$ - profundidade de injeção $(\mathrm{m})$;

$\gamma_{s}$ - peso específico do solo;

$h_{w}$ - altura de coluna d'água acima do ponto de injeção $(m)$;

$n$-porosidade. 
Capítulo 3 - Características da técnica de injeção de ar

Segundo a EPA (1994) um sistema típico de injeção de ar irá operar aproximadamente a pressões de 70 a 100 kPa (10 a 15 psig).

A pressão inicial aplicada em areias grossas ou cascalho é baixa, pois eles têm uma pressão de entrada de ar baixa. Pequenas diferenças nas propriedades capilares como a pressão de entrada de ar podem exercer grande controle sobre os caminhos do fluxo de ar. A pressão de injeção afeta o tamanho e o formato dos caminhos de ar. O tamanho da zona de influência aumenta com o aumento da pressão de injeção, e altas saturações de ar são obtidas com grandes pressões de injeção, que estão limitados pelo fraturamento do solo e eventual geração inapropriada de pressão de água.

A pressão de injeção de ar que tem o melhor custo-benefício corresponde à pressão requerida para manter a mínima vazão necessária para a volatilização dos contaminantes (MARLEY; HAZEBROUCK; WALSH, 1992).

\subsubsection{Vazão (Taxa de fluxo)}

É necessário prover uma vazão de ar suficiente para produzir uma transferência de massa desejável em um dado volume de solo. A vazão deve garantir uma porcentagem de saturação de ar adequada dentro da zona de saturação. Quanto mais fundo for o poço de injeção maior será a vazão a ser aplicada, para que ocorra uma remediação satisfatória.

A vazão aumenta com o aumento da pressão de injeção, essa relação é afetada pelas propriedades do aqüífero que determinam a geometria da zona de influência e a permeabilidade ao ar (LUNDEGARD; ANDERSEN, 1996).

Valores típicos de vazão encontrados na literatura podem ser observados na Tabela 3.1; esses valores são por ponto de injeção e dependem da geologia e da profundidade de injeção. 
Capítulo 3 - Características da técnica de injeção de ar

Tabela 3.1 - Valores de vazão encontrados na literatura.

\begin{tabular}{cc}
\hline Vazão & Referência \\
\hline 30 a $400 \mathrm{l} / \mathrm{min}$ (1 a $15 \mathrm{scfm})$ & Sutersan, 1997 \\
85 a $280 \mathrm{l} / \mathrm{min}$ (3 a $10 \mathrm{scfm})$ & Marley, Hazerbrouck e Walsh, 1992 \\
85 a $700 \mathrm{l} / \mathrm{min}$ (3 a $25 \mathrm{scfm}$ ) & EPA, 1994 \\
Menor do que $140 \mathrm{l} / \mathrm{min}$ (biodegradação) & Lesson et. al., 2002 \\
280 a $570 \mathrm{l} / \mathrm{min}$ (volatilização) & \\
\hline
\end{tabular}

Leeson et al. (2002) afirmam que vazões menores do que $140 \mathrm{l} / \mathrm{min}$ (biodegradação) não são eficientes. Eles acreditam que usar o método de pulsar (liga/desliga) com curtos períodos de injeção e com altas vazões é uma estratégia melhor para a remoção do que baixas vazões.

Segundo a EPA (1994) se o sistema de SVE for usado em conjunto com a injeção de ar a vazão de injeção deve variar de 20 a $80 \%$ da vazão de extração dos vapores.

Aumentando a vazão de ar no solo aumenta a taxa de remediação na maioria dos casos, mas segundo Johnson et al. (1993) não se pode usar a máxima vazão devido a algumas limitações como, por exemplo:

- Limitações mecânicas: aumento na vazão requer grandes pressões de operação o que pode exceder a capacidade do equipamento usado;

- Considerações do solo: a pressão pode sobrecarregar o solo acima do ponto de injeção, causando deformações na estrutura do solo ou fluidificação;

- Altas vazões diminuem a biodegradação.

\subsubsection{Injeção de ar por pulso}

Quando não há mais injeção de ar no solo a água e o NAPL voltam para os canais formados durante a injeção os quais eram ocupados pelo ar. Isso causa uma redistribuição de água pelos poros, e os NAPLs podem ser desalojados. Ciclos (pulsos) acontecem quando o sistema de injeção de ar é ligado e desligado durante o processo de descontaminação. Isso aumenta a remoção de massa, pois traz água 
Capítulo 3 - Características da técnica de injeção de ar

nova e NAPL residual em contato com a injeção de ar. Ciclos longos como os de 12 a 24 horas são mais eficientes.

Aplicando-se o método de pulsar tem-se um aumento na zona de influência, mas como Ji et al. (1993) puderam notar em seus experimentos isso não aconteceu, apenas houve um espalhamento das bolinhas de vidro (material utilizado no ensaio); eles concluíram que esse método de pulsar pode produzir efeitos indesejáveis no campo. Provavelmente isto ocorreu devido à utilização de altas pressões de injeção a pequenos intervalos de tempos entre as injeções de ar.

Segundo Ahlfeld; Dahmani e Ji (1994) os caminhos de ar formados durante cada ciclo sucessivo de operação é quase o mesmo, por isso não se deve esperar que a água migre para novas direções.

Os estudos feitos por Lundegard e LaBreque (1995) através do ERT, tomografia de resistência elétrica (Electrical Resistance Tomography), mostraram que não há mudança na forma e no tamanho da zona de influência quando o método de pulsar é aplicado.

Algumas vantagens de se usar a injeção por pulso segundo Mickelson (2003) são:

- Aumento na mistura da água subterrânea diminuindo as limitações da difusão, e fazendo com que a volatilização seja acelerada;

- A injeção de ar trata primeiro contaminantes na fase dissolvida. Com o aumento da mistura da água subterrânea pode haver um aumento na taxa de dessorção dos contaminantes, acelerando a remediação.

Quando a biodegradação é a meta principal (em vez da volatilização), a transferência de oxigênio é mais eficiente se o método de injeção por pulsação for usado no lugar da injeção contínua. Segundo Leeson et al.(2002) o método de injeção em ciclos é mais vantajoso, pois é mais barato tanto em termos de operação como de equipamentos. 


\subsubsection{Profundidade de injeção}

Através de modelagem numérica, Lundegard e Andersen (1996) mostraram que a profundidade de injeção tem pouca influência na largura da zona de influência durante o estado de equilíbrio. Já Baker e Benson (2007) em seus estudos usando bolinhas de vidro notaram que o raio de influência aumentava com o aumento da profundidade de injeção, mas isso só acontecia até metade da profundidade do tanque usado no experimento (aproximadamente $350 \mathrm{~mm}$ ); após esta profundidade a largura da zona de influência se manteve constante.

A profundidade de injeção deve ser pelo menos 30 a $60 \mathrm{~cm}$ abaixo do ponto mais fundo de contaminação. Segundo Suthersan (1997) tem-se usado profundidades de 9 a $18 \mathrm{~m}$ (30 a $60 \mathrm{ft}$ ) abaixo do nível d'água. Quanto mais fundo for o ponto de injeção mais ar será necessário para manter a porcentagem de saturação de ar dentro da zona de influência.

Geralmente o método de injeção de ar funciona melhor para aqüíferos com lençol freático raso, mas em casos raros ele também pode ser usado em aqüíferos profundos (MICKELSON 2003). Isto se deve ao fato de que quanto mais profundo se encontra o nível de água mais cara fica a instalação dos poços de injeção e de extração.

\subsection{Densidade dos poços}

A densidade dos poços é a quantidade de poços de injeção por seção. Altas saturações de ar geralmente estão relacionadas com grande número de poços próximos. A densidade dos canais de ar é geralmente descrito pela saturação de ar.

Vários autores como Ji et al. (1993) e Baker e Benson (2007) mostraram que aumentando a vazão ou a pressão de injeção, a saturação de ar também aumenta

O uso de múltiplos poços de injeção produz aparentemente uma superposição dos raios de influência, mas isso não implica que todo o volume de água seja alcançado com a mesma eficiência (AHLFELD; DAHMANI; JI, 1994). 
A saturação de ar e o tamanho das regiões preenchidas de ar (canais de ar) têm grande efeito na taxa de transferência de massa (SUTHERSAN, 1997). Baker (1996) apud Baker e Benson (1996) notou que a saturação de ar não é uniforme, e que grandes saturações de ar existem perto do ponto de injeção.

Aumentando a profundidade de injeção a saturação de ar irá diminuir, quando a vazão for constante. Segundo estudos de Lundegard e Labrecque (1995) durante a injeção a saturação de água cai para 40 a 50\% na região principal do fluxo de ar. Isto está relacionado com a curva de retenção de água e a entrada de ar no solo.

Segundo Lundegard e Labrecque (1995) a re-saturação de água na região de fluxo de ar após o desligamento do sistema de injeção é considerável, mas não é completa; bolhas de ar podem ficar presas nos vazios do solo. A maior e mais rápida re-saturação ocorre na região de maior profundidade de injeção.

\subsection{Raio de influência ou Zona de influência}

A zona de influência pode ser definida como o volume de solo saturado com ar em volta do poço de injeção onde o fluxo de ar pode ser detectado. Essa área que é atingida pelo ar durante a injeção é importante porque o ar é o meio de transporte dos contaminantes, assim o processo de remoção dado pela volatilização é mais eficiente quanto maior for à área atingida pelo fluxo de ar.

O tamanho da zona de influência é geralmente descrito pelo raio de influência $\left(R_{i}\right)$. No entanto, a pluma de ar raramente é circular ou simétrica como se pode ver na Figura 3.1, por conta disto uma melhor designação seria zona de influência. A simetria se dá apenas em solos homogêneos. 


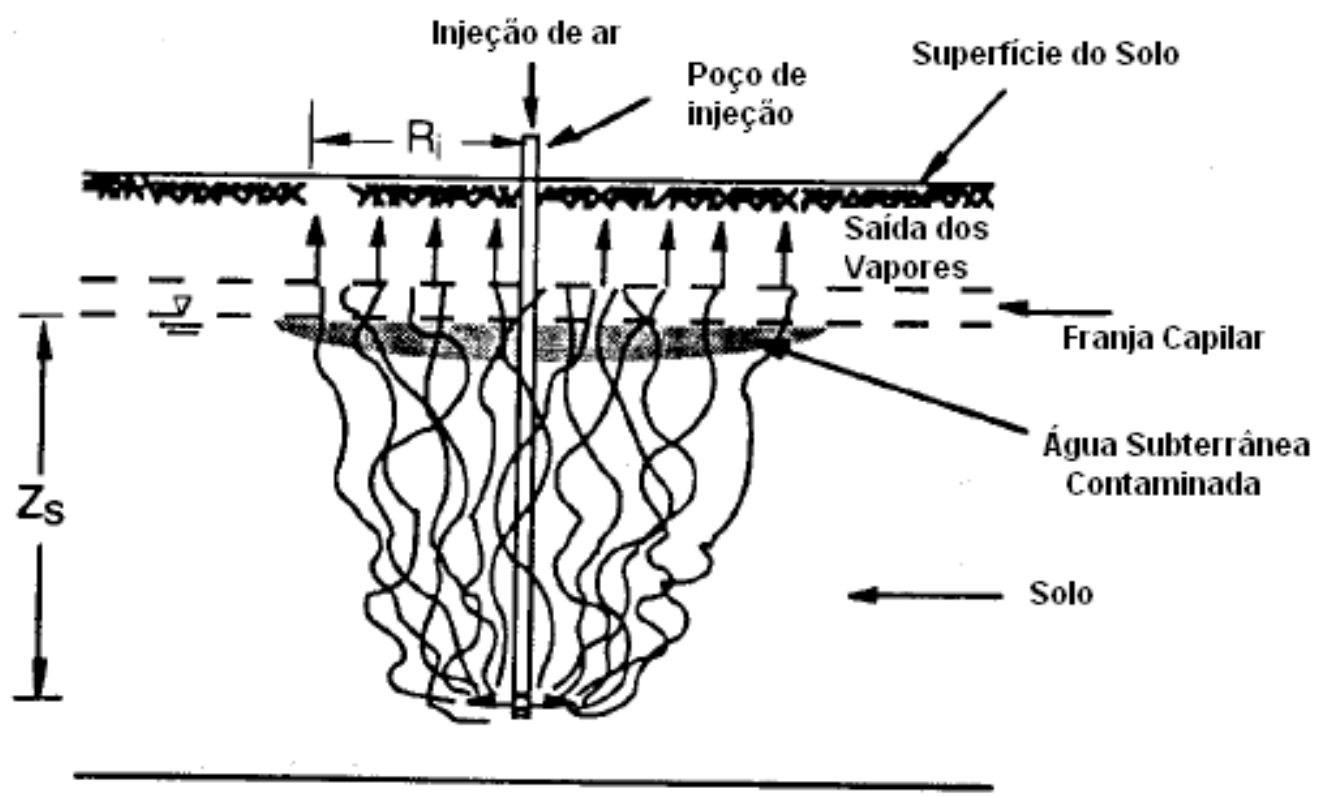

Figura 3.1 - Esquema típico de injeção de ar (adaptado de Baker e Benson (1996))

O raio de influência é muito variável principalmente em solos heterogêneos e com estratificações. Segundo Marley; Hazebrouck e Walsh (1992) em solos grossos onde a distribuição vertical dos canais de ar é mais controlável e previsível, a injeção de ar tende a formar uma zona de influência parabólica em direção a região não saturada.

O termo raio de influência às vezes é usado para determinar o volume de água que é influenciado pela aplicação do método de injeção de ar. Grandes raios de influência são obtidos através de altas pressões e grandes profundidades de injeção.

Segundo Ahlfeld, Dahmani e Ji (1994), o termo zona de influência só deveria ser usado para descrever aproximadamente a maior distância que os canais de ar atingem na direção radial desde o ponto de injeção; e não deveria se assumir que os contaminantes dentro dessa zona são remediados com eficiência.

A distribuição do fluxo de ar e a saturação de ar dependem das condições de operação e da pressão de entrada de ar do solo. Para injeções de ar com pressões baixas o formato dos caminhos de ar (raio de influência) é de um cone invertido com o ápice no ponto de injeção, ou seja, a forma de um $V$ já para pressões de injeção alta o formato é de um U. 
Capítulo 3 - Características da técnica de injeção de ar

A zona de influência é afetada pelas características do solo (granulometria, permeabilidade e estratificações), pressão de injeção e profundidade de injeção. $O$ tamanho da zona de influência aumenta com o decréscimo da permeabilidade ao ar, por exemplo, areias grossas possuem uma zona de influência mais estreita do que as areias finas.

Nos estudos realizados por Baker e Benson (2007) o formato dos caminhos de ar encontrado foi de um $V$ formando um ângulo de 40 a $60^{\circ}$ com o ápice, em solos médios a grossos (tamanho dos grãos variando de 4,7 a $1,1 \mathrm{~mm}$ ), médios a finos $(0,85$ a $0,31 \mathrm{~mm})$ e solos bem graduados $(4,7$ a $0,11 \mathrm{~mm})$. E para solos com partículas muito pequenas uma zona de influência não fica bem definida.

Segundo Marley; Hazebrouck e Walsh (1992) em condições ideais, o raio de influência possível é limitado pela pressão de injeção que pode produzir fraturas no solo ou movimentos turbulentos do fluxo de ar.

Lundegard e Labrecque (1995) mostraram que métodos comuns de monitoramento indireto do raio de influência em campo causam muitos erros chegando a valores duas a oito vezes maiores do que os valores encontrados por métodos diretos, como o ERT (Electrical Resistence Tomography) tomografia de resistência elétrica por exemplo.

Os métodos indiretos mais comuns utilizados em campo são o monitoramento do nível d'água, mudanças da pressão de gás na zona não saturada, concentrações de oxigênio dissolvido e concentrações com um gás traçador (hélio é o gás mais usado). O gás utilizado como traçador não pode ser encontrado naturalmente no local de estudo, pois pode influenciar os resultados encontrados durante 0 monitoramento. Os métodos diretos são ERT (tomográfica de resistência elétrica), bolhas de saída local e TDR (reflectômetria no domínio do tempo)

O monitoramento do nível d'água foi umas das primeiras técnicas usadas para se medir a zona de influência, mas percebeu-se que a mudança era apenas um deslocamento da água para uma acomodação inicial do ar e que não refletia a zona de influência causada pela injeção de ar, além disso, a elevação do nível de água 
desaparece durante a fase de equilíbrio. O uso do monitoramento do nível de água para se estimar a zona de influência causa uma superestimação da área afetada. As concentrações de oxigênio dissolvido (OD) durante os testes pilotos sofrem um aumento que não está totalmente relacionado às mudanças de $\mathrm{OD}$ do aqüífero.

A medida da concentração de um gás traçador não é uma boa indicação da zona de influência, pois como pode ser visto na Figura 3.2 fica difícil de distinguir o caminho $A$ do $B$, especialmente se a medida for feita apenas no poço de monitoramento 2. $O$ caminho A mostra um fluxo do poço de injeção pela zona saturada e depois continua pela zona não saturada até o poço de monitoramento e já o caminho $B$ indica um fluxo direto do poço de injeção pela zona saturada. O caminho percorrido por B é maior na zona saturada fazendo com que uma maior concentração de contaminante seja volatilizada do que pelo caminho $A$.

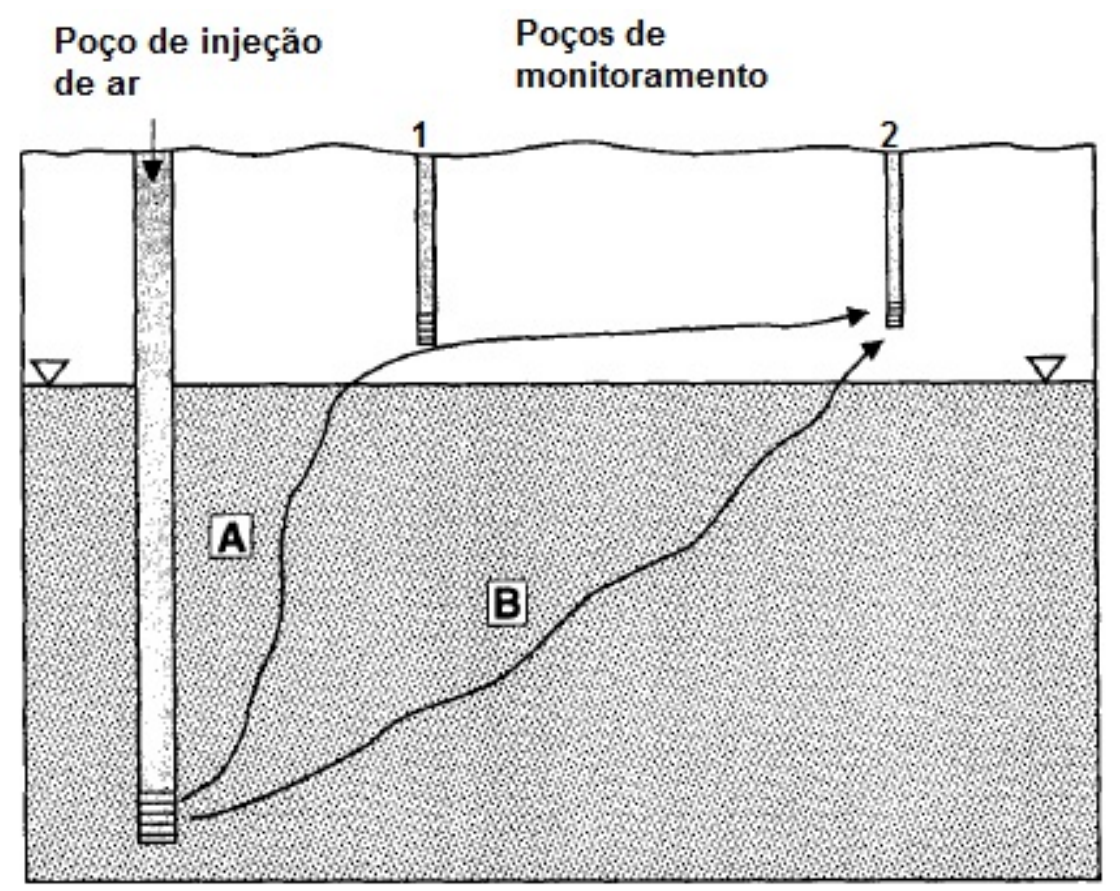

Figura 3.2 - Dois caminhos de fluxo de ar hipotéticos (adaptado de Lundegard e Labrecque (1995))

O ERT é um método tridimensional que possibilita a determinação da saturação de ar dentro da zona saturada. Isso é feito através da medida da resistência elétrica do solo com eletrodos colocados nos poços durante a instalação. Segundo Lundegard e Labrecque (1995) no ETR a mudança na resistividade durante a injeção de ar 
significa mudança na saturação do fluido; e esse método é considerado o mais direto e preciso que representa a região de fluxo de ar na zona saturada. Já o TDR é usado para medir a umidade volumétrica, pois quando o ar passa pela zona de influência a umidade volumétrica diminui devido ao deslocamento da água, as medidas também são bem precisas. A distribuição da resistividade é função da saturação de água, porosidade, teor de argila e da condutividade elétrica da água nos poros. Áreas com baixa saturação de água, criadas pela injeção de ar irão apresentar uma alta resistividade.

Para que o sistema de injeção de ar seja aplicado com a máxima eficiência é necessário entender os caminhos do fluxo de ar para se determinar o melhor local de instalação, número e condições de operação dos poços. Sempre é aconselhável fazer testes pilotos no local para se ter uma estimativa da zona de influência e do número de poços de injeção.

\subsection{Comportamento do fluxo}

O comportamento do fluxo tem três estágios: (1) período de transição inicial, crescimento dos limites lateral e vertical do fluxo de ar (estágio de expansão); (2) período de transição, redução do limite lateral do fluxo de ar (estágio de colapso); (3) estágio de estado de equilíbrio, durante o qual o sistema permanece estático; os três estágios podem ser visto na Figura 3.3.
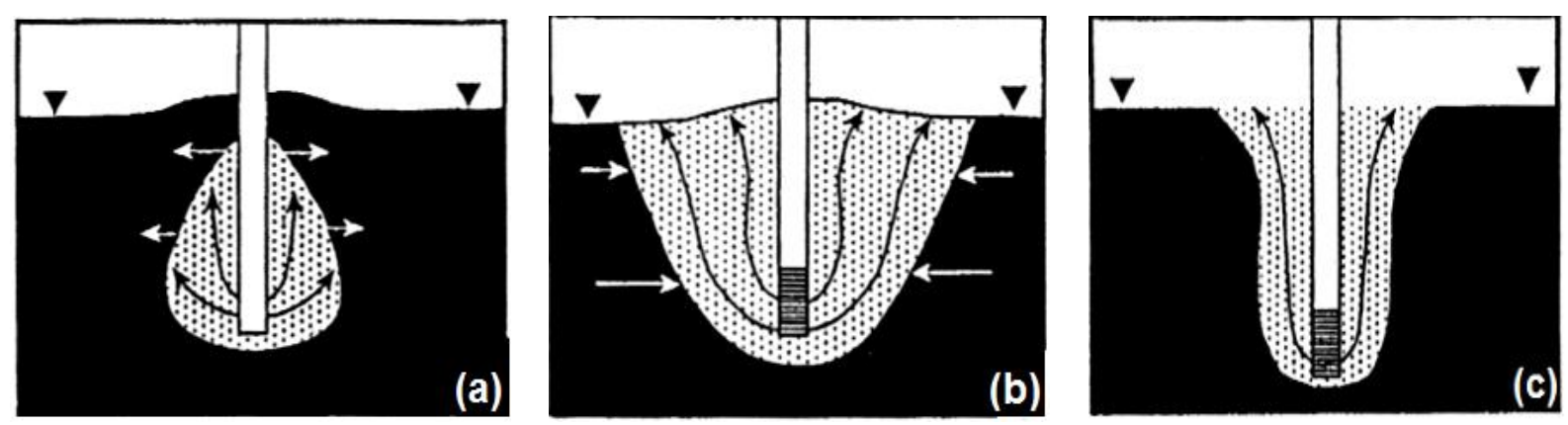

Figura 3.3 - Comportamento do fluxo, em (a) fase de expansão, (b) inicio do colapso e (c) estado de equilíbrio (USACE (2008))

O tempo que um sistema leva para passar do estágio de transição para o estado de equilíbrio depende de vários fatores, incluindo a permeabilidade, estrutura do 
Capítulo 3 - Características da técnica de injeção de ar

aqüífero, profundidade de injeção, anisotropia, pressão de injeção e vazão (LUNDEGARD; ANDERSEN, 1996).

Em um solo homogêneo e com alta permeabilidade o estado de equilíbrio é atingido rapidamente, já para um solo heterogêneo as pressões envolvidas são bem maiores e de maior duração; por isso a pressão leva mais tempo para se dissipar, ou até mesmo se dissipa quando o sistema de injeção é completamente desligado.

Segundo as simulações de Lundegard e Andersen (1996), durante o estágio de expansão a zona de influência aumenta em volume, e tem a forma de um sino até o ar começar a atingir a zona não saturada. E é nessa fase que o nível de água sobe atingindo o seu ápice. Após a zona não saturada ser alcançada pelo ar a forma da zona de influência é a de um cone. Como a permeabilidade ao ar aumenta com a diminuição da saturação de água do solo, mais ar consegue atingir a zona não saturada, causando o estágio de colapso da zona de influência. Durante essa fase a forma cônica fica mais fina. Muitos dos poros que continham ar na fase de expansão agora voltam a ter água na fase de colapso, é quando o nível de água começa a voltar para seu nível normal.

Quando a pressão de ar se iguala à pressão hidrostática, o estado de equilíbrio é alcançado não havendo mais mudanças na forma e volume da zona de influência. Simulações feitas por Lundegard e Andersen (1996) mostraram que com o aumento da profundidade de injeção o tempo da fase de transição (expansão e colapso) também aumenta. Isso ocorre não apenas por causa do aumento no comprimento dos canais de ar, mas também devido à diferença de densidade entre ar e água no aqüífero que diminui com o aumento da profundidade.

A diferença na forma e volume da zona de influência na fase de transição para o estado de equilíbrio pode ser maior em solos heterogêneos e com permeabilidades baixas.

Uma das maneiras de se medir o tempo da fase de transição é através de valores de vazão ou pressão de injeção; em estudos realizados por Lundegard e Labrecque (1995) o tempo que esses parâmetros levaram para se estabilizar foi de 2 horas, 
mas os dados do ERT mostraram que o nível de água só se estabilizou com 4 horas. Como isso se pode dizer que a estabilização do nível de água é a melhor indicação do início da fase de equilíbrio.

\subsubsection{Variação do nível d'água}

A variação do nível de água está relacionada com o comportamento do fluxo, pois essa variação só acontece devido ao período de transição (expansão e colapso). Quando se aplica ar na zona saturada do solo o lençol freático tem que se deslocar para dar lugar ao ar, isso pode causar um movimento tanto horizontal como vertical da água. A movimentação lateral da água pode fazer com que os contaminantes sejam levados para regiões onde antes não havia contaminação. A variação do nível d'água é um fenômeno apenas temporário, sumindo com o alcance do estado de estabilidade do método.

Primeiro tem-se uma expansão na região do fluxo de ar como pode ser visto na Figura 3.4. Segundo Suthersan (1997) durante essa fase a taxa de injeção de ar (vazão de entrada) na zona saturada excede a taxa de fluxo de ar que sai para a zona não saturada (vazão de saída). É aí que o nível d'água sobe atingindo o seu ápice. O volume de água deslocado depende da pressão de injeção do ar e das propriedades do solo.

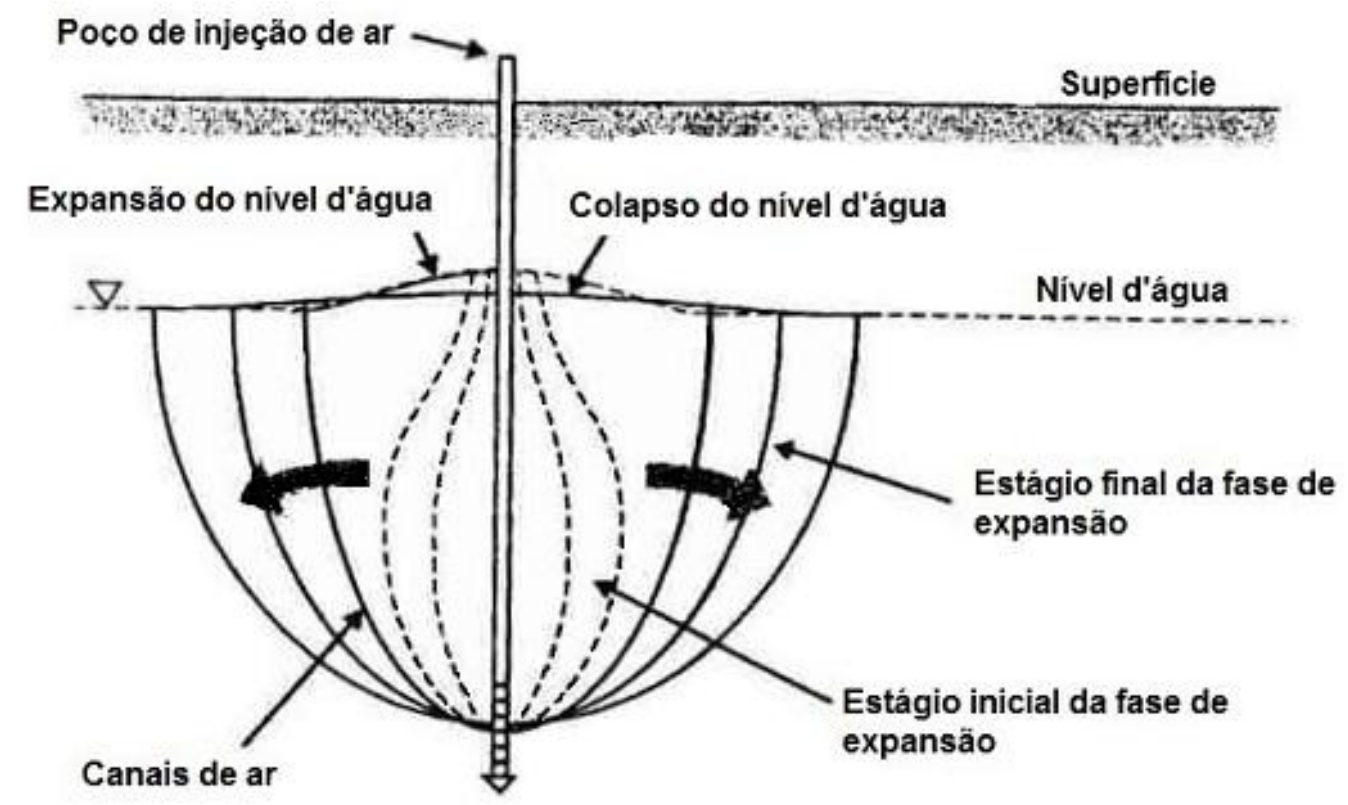

Figura 3.4 - Expansão do nível d'água (adaptado de Suthersan (1997)) 
A diminuição da pressão longe do poço de injeção causa um colapso nos canais de ar; quanto mais afastados os canais se encontrarem do poço de injeção mais rápido esse colapso irá ocorrer, por isso os canais de ar ficam confinados na região de alta permeabilidade perto do ponto de injeção.

Quando a injeção de ar penetra na zona não saturada a zona de influência diminui, ver Figura 3.5. A zona de distribuição de ar encolhe até a taxa de ar que sai para a zona não saturada se igualar a taxa de injeção de ar atingindo um equilíbrio. É por isso que na situação de equilíbrio não há mais variação do nível d'água.

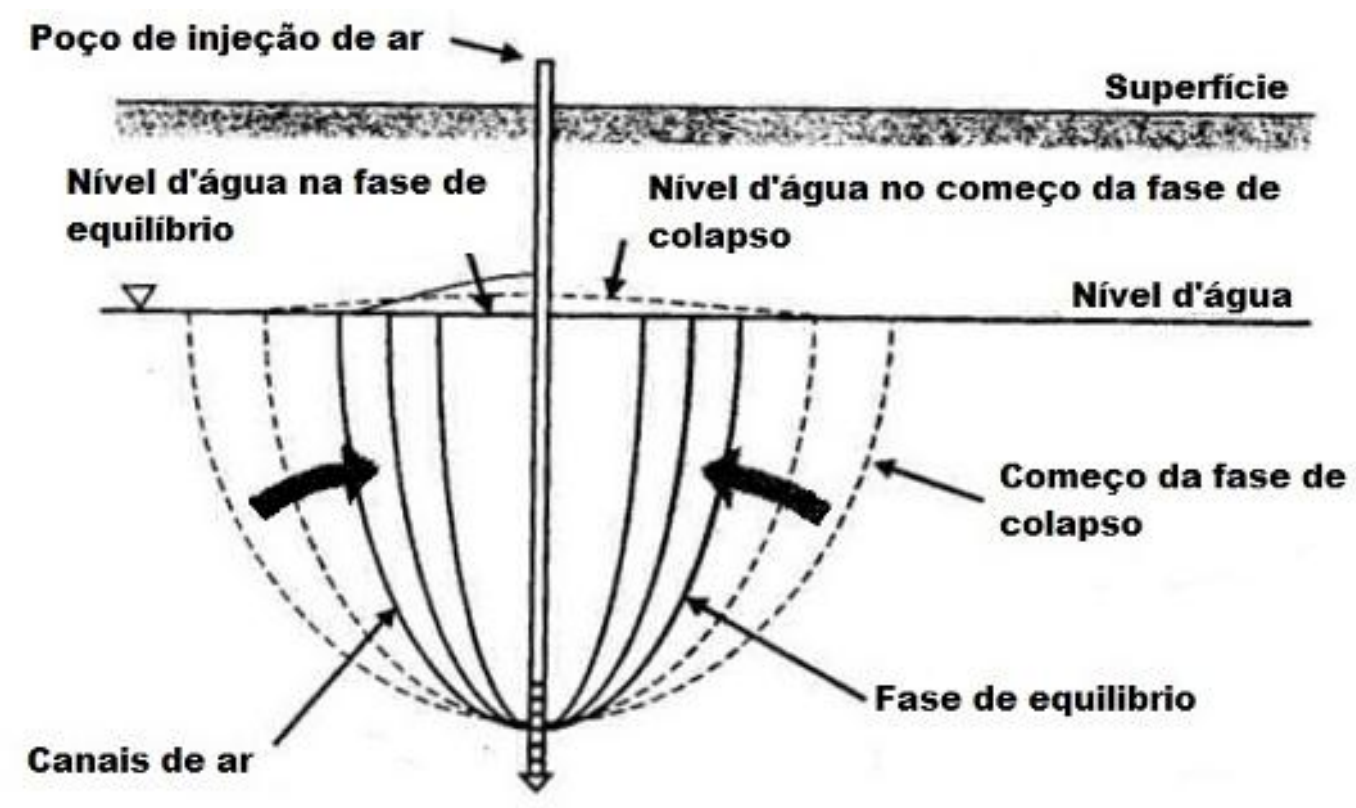

Figura 3.5 - Estado de equilíbrio durante a injeção de ar (adaptado de Suthersan (1997))

Johnson et al. (1993) afirmam ser improvável que a injeção de ar no solo sozinha consiga manter o nível de água acima do normal, sendo a hipótese mais plausível que a elevação seja devido ao uso do SVE em conjunto com o método de injeção de ar.

Nos estudos realizados por Lundegard e Labrecque (1995) a elevação do nível de água encontrada foi aproximadamente simétrica radialmente acima do poço de injeção, o que indica que para este caso a permeabilidade horizontal é praticamente a mesma que a vertical. 
Capítulo 3 - Características da técnica de injeção de ar

Poços horizontais têm um deslocamento de água durante a injeção de 2,5 a 3 vezes maior do que o deslocamento em poços verticais (PLUMMER; NELSON; ZUMWALT, 1997).

\subsection{Agitação da água subterrânea}

A agitação da água subterrânea durante a injeção de ar é importante para providenciar um transporte de oxigênio adequado.

Segundo Suthersan (1997) há várias formas dessa agitação da água subterrânea ocorrer durante a injeção de ar como, por exemplo:

- Deslocamento físico devido à injeção de ar;

- Interação capilar entre o ar e a água;

- Migração de finos;

- Arraste por fricção causada pela passagem do ar;

- Convecção térmica;

- Fluxo de água em resposta a perda por evaporação.

A agitação por deslocamento físico ocorre durante a fase instável do processo, onde a porcentagem de saturação de ar varia com o tempo (SUTHERSAN, 1997).

A migração de finos, arraste por fricção, convecção térmica e perda por evaporação podem causar a mistura da água durante a fase estável, mas são menos significativas do que as que ocorrem durante a fase instável. O método de pulso de injeção aumenta o volume de água misturada.

O movimento da água induzido pela evaporação tem potencial para melhorar o desempenho da remediação se a velocidade da água for maior do que $2 \mathrm{~cm} /$ dia na ocorrência de canais de ar (JOHNSON, 1998). 


\subsection{Testes Pilotos em Campo}

O primeiro objetivo dos testes pilotos é avaliar a viabilidade da utilização do método, em determinada área. As falhas mais comuns da aplicação desse método são: a saída do ar da zona saturada ocorrer muito longe do ponto de injeção e em solos de baixa permeabilidade, a ocorrência de fratura do solo, devido ao alto valor da pressão de entrada de ar desse tipo de solo. O objetivo mais comum é avaliar a zona de influência próxima ao ponto de injeção. Além disso, os testes pilotos também determinam a pressão de injeção a ser utilizada, a vazão, a pressão de entrada de ar, a duração da elevação do nível de água, a necessidade da utilização do sistema de SVE e o espaçamento adequado dos poços de injeção. Testes pilotos são ferramentas que ajudam no entendimento do comportamento da injeção de ar no solo contaminado.

A maioria dos projetos de remediação são baseados em projetos realizados anteriormente em locais com as mesmas características litológicas e com contaminantes semelhantes. Isso se deve ao fato do teste piloto ter um alto custo, por isso à realização de testes pilotos não é uma prática comum.

Estudos em campo são indispensáveis, mas são complicados devido às várias incertezas, particularmente aquelas que dizem respeito à geologia do local. Em campo a maioria dos lugares onde será necessária uma remediação do solo, há uma predominância de solos médios e finos ao invés de solos grossos por isso 0 fluxo por canais prevalecerá sobre o fluxo em bolhas.

A Tabela 3.2 apresenta as vantagens do dimensionamento de sistemas através de testes pilotos, segundo Morais Júnior (2009). 
Capítulo 3 - Características da técnica de injeção de ar

Tabela 3.2 - Vantagens dos testes pilotos "in situ".

\begin{tabular}{lll}
\hline \multicolumn{2}{c}{ Custo } & \multicolumn{2}{c}{ Eficiência } \\
\hline Estimativa dos custos e do tempo de & $\begin{array}{l}\text { Aumento da eficiência do sistema de } \\
\text { remediação. }\end{array}$ & $\begin{array}{l}\text { remediação. } \\
\text { Otimização da quantidade de poços de } \\
\text { injeção e da capacidade do sistema } \\
\text { massa de contaminantes em função do } \\
\text { tempo. }\end{array}$ \\
\hline
\end{tabular}

O teste piloto em campo serve apenas para a área em que foi realizado. É por esse motivo que se deve fazer um teste piloto para cada lugar diferente que se esteja analisando.

Segundo Suthersan (1997) testes pilotos em campo geralmente são realizados com uma duração menor do que 24 a 48 horas e monitoram:

- Pressão e vazão de injeção;

- O aumento gradual em piezômetros abaixo do nível d'água (elevação do nível de água);

- Níveis de oxigênio dissolvido;

- Concentrações e composição de contaminantes no solo;

- Pressões de gases nos solos.

Os principais equipamentos necessários para o teste piloto são o compressor de ar, válvulas de controle de pressão e vazão, piezômetros e poços de monitoramento de gases na zona não saturada.

A distribuição do fluxo de ar é sensível a qualquer mudança na estrutura do solo, pode ter forma irregular e caminhos preferências de fluxo. Baixas vazões são mais baratas e menos eficientes na distribuição de ar; aumentos na vazão (e injeção de ar) causam um aumento na densidade do ar o que pode fazer com que o ar atravesse as lentes de baixa permeabilidade encontradas nos solos. O desempenho do método está diretamente relacionado à distribuição de ar na zona a ser remediada. 
Capítulo 3 - Características da técnica de injeção de ar

Pode-se otimizar as distâncias entre os poços de injeção, ou seja, diminuir o número de poços, quando se tem uma boa caracterização da distribuição de ar em ensaios piloto.

\subsection{Projeto, Operação e Monitoramento}

Para cada local onde se pretende instalar o método de injeção de ar é preciso realizar um estudo das construções ao redor, traçar o perfil geológico do solo, conhecer o tipo de contaminante e sua concentração, para poder dimensionar os poços de injeção sua localização e número.

O projeto e operação do sistema de injeção de ar são feitos para se maximizar os mecanismos de remoção e minimizar as conseqüências adversas como a migração de vapores dos contaminantes para áreas não contaminadas. Para que a remediação seja satisfatória são necessários operadores experientes; seguido de testes pilotos para se determinar as características operacionais a serem utilizadas durante a descontaminação.

O monitoramento é usado para avaliar as condições de operação, para determinar se o sistema precisa de ajustes ou expansões, e para determinar se tem migrações de vapores indesejados. O monitoramento adequado dentro da zona de injeção de ar é feito através de poços de monitoramento e piezômetros.

Para a injeção de ar é utilizado um compressor que não deve conter nenhum tipo de contaminante (gasolina, óleo, etc) para seu funcionamento de modo a assegurar que nenhum novo contaminante seja introduzido no aqüífero.

\subsubsection{Poços de Injeção e Monitoramento}

Os poços de injeção de ar e monitoramento são muito semelhantes na sua construção a única diferença é quanto à instalação, pois o poço de injeção deve ser colocado na zona saturada e o de monitoramento na zona não saturada. Os poços descritos aqui são utilizados em campo. Nos ensaios de laboratório usam-se poços diferentes como pode ser visto mais adiante na Secção 4.5. 
Geralmente o poço de injeção de ar é colocado dentro de outro poço que é preenchido com uma argamassa, geralmente bentonita, que sela este poço externo para que o ar não encontre a parede do poço de injeção como caminho preferencial de passagem de ar. No ponto de injeção é construído um filtro com material de granulometria semelhante ao do solo do aquífero para facilitar a injeção de ar no solo, pois se o tamanho médio dos grãos do filtro for menor do que o do solo, o filtro pode se tornar menos permeável do que o solo, fazendo com o ar tenha dificuldade de penetrar no solo. A Figura 3.6 apresenta um desenho esquemático do poço de injeção de ar. O filtro serve para fazer a transferência do ar do poço de injeção para o solo contaminado.

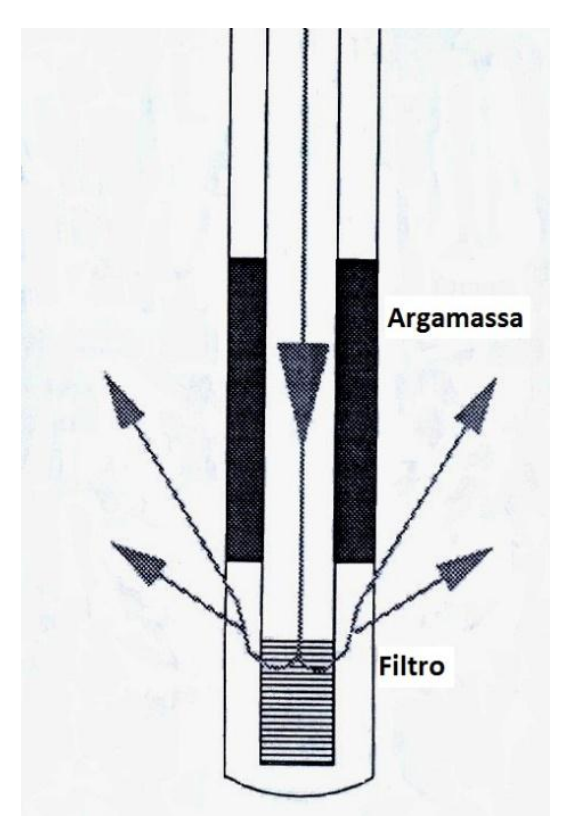

Figura 3.6 - Desenho esquemático mostrando a argamassa e o filtro (adaptada de Johnson et al. (1993)).

O material mais comum usado na construção dos poços é o PVC (polipropileno), mas também podem ser feitos de aço inoxidável.

Segundo Johnson et al. (1993) o diâmetro dos poços de injeção varia de 2,5 a 10 $\mathrm{cm}$; sendo que os poços com diâmetros de até $5 \mathrm{~cm}$ são mais baratos e fáceis de serem instalados. A instalação deve ser feita na zona saturada abaixo do ponto mais baixo de contaminação do solo tanto para poços verticais com horizontais. 
Capítulo 3 - Características da técnica de injeção de ar

O número e a localização dos poços de injeção de ar devem ser escolhidos para maximizar o fluxo de ar pela região contaminada. A Tabela 3.3 apresenta alguns dos espaçamentos entre os poços encontrados na Literatura.

Tabela 3.3 - Espaçamentos entre poços encontrados na Literatura.

\begin{tabular}{cc}
\hline Referência & Espaçamento entre poços \\
\hline Mickelson (2003) & 3,6 a $15 \mathrm{~m}$ \\
Leeson et al. (2002) & $4,6 \mathrm{~m}$ (em solos homogêneos e de alta \\
& permeabilidade) \\
\hline
\end{tabular}

\subsubsection{Poços Horizontais}

A injeção de ar pode ser feita tanto em poços verticais como em poços horizontais. $\mathrm{Na}$ Tabela 3.4 podem ser vistas algumas das condições do local de instalação do poço de injeção de ar com relação ao tipo de poço utilizado.

Tabela 3.4 - Orientação do poço de injeção (adaptado de EPA (1994))

\begin{tabular}{cl}
\hline Orientação do poço & \multicolumn{1}{c}{ Condições do local de instalação } \\
\hline Poço vertical & $\begin{array}{l}\text { Profundidade de contaminação }>7,6 \mathrm{~m}(25 \text { feet }) \\
\text { Profundidade do nível de água }<3 \mathrm{~m}(10 \text { feet }) \\
\text { Menos de } 10 \text { poços de injeção }\end{array}$ \\
Poço horizontal & $\begin{array}{l}\text { Profundidade de contaminação }<7,6 \mathrm{~m} \text { (25 feet) } \\
\text { Zona de contaminação com alguma estratificação }\end{array}$ \\
\hline
\end{tabular}

Segundo estudos realizados por Plummer; Nelson e Zumwalt (1997) poços horizontais são mais eficientes do que poços verticais, pois a distribuição de ar é mais completa e uniforme neste tipo de poço. Ainda de acordo com os mesmos pesquisadores historicamente poços verticais são mais usados na descontaminação dos solos, mas seu uso tem suas desvantagens, tais como:

- Os poços verticais devem ser instalados abaixo da pluma de contaminação, e sua localização é limitada por obstruções na superfície como construções, lagos e rios. 
- Características hidrogeológicas e a distribuição dos contaminantes freqüentemente são orientadas em plano horizontal, assim reduzindo a eficiência dos poços verticais.

- O poço vertical pode conectar aqüíferos que estão separados; em níveis diferentes; atravessando lentes impermeáveis que os separavam, assim a contaminação pode atingir lugares antes sem contaminação.

- Vários poços verticais são necessários para remediar uma pluma de contaminação, especialmente em solos de baixa permeabilidade

- Poços verticais não podem cruzar fraturas verticais.

Poços horizontais melhoram a superfície de contato com os contaminantes e aumenta a acessibilidade a plumas de contaminação localizadas abaixo de superfícies obstruídas, na Figura 3.7 pode ser observado o poço de injeção horizontal.

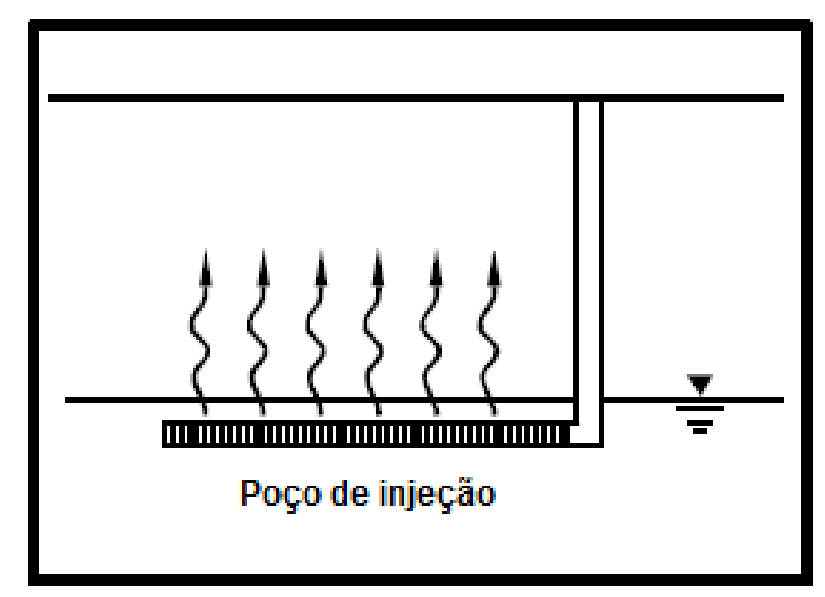

Figura 3.7 - Poço de injeção horizontal (modificado de EPA (1994))

Os estudos de Plummer; Nelson e Zumwalt (1997) mostraram que a vazão de entrada de ar em poços horizontais é 1,5 a 2 vezes maior do que em poços verticais. A injeção de ar através de poços horizontais é mais eficiente, pois há a formação de mais canais de ar, fazendo com que o volume de água deslocado seja maior. Devido à sua estrutura a instalação de poços horizontais é mais complexa do que a de poços verticais. 


\subsection{Taxa de Remediação}

A taxa de remediação é definida como a quantidade de solo contaminado remediado durante um intervalo de tempo.

Segundo Ahlfeld et al. (1994) quando a transferência de massa é limitada pela habilidade do contaminante migrar pelos canais de ar (difusão), a localização, o número, e a densidade dos canais de ar influenciam na volatilização dos contaminantes.

A presença de contaminantes na fase livre (NAPL) atrapalha a eficiência do método, pois primeiramente o contaminante tem que se dissolver na fase aquosa, para então poder migrar para os canais de ar por convecção ou difusão.

Aumentando o número de poços de injeção, ou seja, diminuído o espaçamento entre eles a taxa de remediação deve aumentar, por isso quanto mais poços instalados melhor, desde que o fator econômico seja considerado.

A remoção em curto prazo é dominada pela remoção de contaminantes que se encontram dentro dos canais de ar; já a remoção em longo prazo é governada pela remoção dos contaminantes encontrados fora dos canais de ar, e é limitada pelo processo de transferência de massa da fase liquida ou pela evaporação da água dos canais de ar que podem resultar em transferência de massa através da advecção. A remoção para um mesmo solo é tanto mais eficiente quanto maior a densidade de canais de ar.

Segundo Leeson et al. (2002) quando a remoção em longo prazo é limitada pela transferência de massa da fase aquosa, a remoção se torna independente das propriedades químicas normalmente associadas a volatilização, como pressão de vapor e a Lei de Henry. A taxa de remediação depende do grau de contato entre ar e água contaminada e/ou gânglio de NAPL, e também depende do tempo de injeção. 


\subsection{Considerações do método}

Segundo Suthersan (1997) o tempo necessário para que haja descontaminação depende da:

- Extensão da contaminação, tanto da fase dissolvida quanto da adsorvida;

- Massa de contaminante presente na zona saturada e na franja capilar;

- Presença de DNAPL;

- A volatilização, biodegradação e a capacidade de se remover o contaminante do solo;

- Solubilidade dos contaminantes;

- Condições geológicas que afetam: a porcentagem de saturação de ar, a densidade dos canais e o tamanho dos canais de ar.

O método de injeção de ar não é indicado para lugares com contaminantes que não sejam de fácil volatilização ou biodegradação. Concentrações muito altas de éter metil-terciário butílico (MTBE) é um exemplo de contaminante de difícil remoção por esse método.

O método convencional de injeção de ar só deve ser usado em locais com condições geológicas apropriadas. Lentes de baixa permeabilidade ou qualquer outra heterogeneidade geológica que limite a migração vertical do ar para a zona não saturada limitam a eficiência do método. Vários autores indicaram que a permeabilidade à água do solo deve ser pelo menos $10^{-3} \mathrm{~cm} / \mathrm{s}$ (solo arenoso) para que se tenha uma taxa de injeção e remoção eficaz. Segundo a EPA (1994) solos com permeabilidades a água abaixo de $10^{-5} \mathrm{~cm} / \mathrm{s}$ são inadequados a injeção de ar, pois a pressão necessária para que 0 ar entre no solo é muito grande e acaba fraturando o solo e criando caminhos preferências para o ar.

Segundo Mickelson (2003) o sistema de extração de vapores (SVE) deve ser usado em conjunto com a injeção de ar quando:

- Alguma construção ou outra estrutura estiver a aproximadamente $30 \mathrm{~m}$ de distância do poço de injeção de ar; 
- Mais de $50 \%$ da superfície for pavimentada dentro de $15 \mathrm{~m}$ dos poços de injeção. A pavimentação pode causar o movimento lateral dos vapores dos VOCs;

- Lentes de argila ou silte estejam presentes na zona não saturada, podendo causar movimento lateral dos vapores de VOCs;

Segundo EPA (1994) uma espessura de pelo menos $1 \mathrm{~m}$ de zona não saturada é necessária para permitir a operação do SVE ou para que a biodegradação dos contaminantes volatilizados seja completa antes de atingir a superfície do solo.

Em locais onde há DNAPLs presentes a injeção de ar pode causar um espalhamento da fase imiscível e aumentar o tamanho e a concentração da pluma de VOCs.

Segundo EPA (1994) algumas das desvantagens da aplicação do método são:

- Não deve ser usado se houver contaminantes na fase livre, (a fase livre deve ser removida antes da aplicação do método);

- Não pode ser usado em aqüíferos confinados, pois o ar pode ficar preso na zona saturada;

- A estratificação do solo pode causar uma ineficiência do método;

- Pode induzir a migração dos contaminantes.

O método de injeção de ar não deve ser usado em locais que haja alta concentração de ferro, pois pode haver precipitação do mesmo no aqüífero, que resulta na redução da porosidade e da permeabilidade. Segundo (MICKELSON 2003) concentrações de ferro dissolvido maiores do que $10 \mathrm{mg} / \mathrm{L}$ podem causar esse tipo de problema.

A

Tabela 3.5 apresenta as características favoráveis para a utilização do método. 
Capítulo 3 - Características da técnica de injeção de ar

Tabela 3.5 - Condições favoráveis para a utilização do método (adaptada de Suthersan, 1997)

Característica

Permeabilidade horizontal à água da

zona saturada

Estratificação e anisotropia

Tipo de aqüífero

Profundidade da contaminação abaixo

do nível de água

Tipo de contaminante

Condições do solo acima do nível de água
Condição favorável

$$
10^{-3} \mathrm{~cm} / \mathrm{s}
$$

Areia e cascalho homogêneo

Não confinado

Menor do que 12 a $15 \mathrm{~m}(40$ a $50 \mathrm{ft})$

Alta biodegrabilidade, alta volatização

Mais do que $1,5 \mathrm{~m}(5 \mathrm{ft})$ de zona não saturada, solo permeável

Quando a injeção de ar cessa o ar sai do solo em 2 a 3 segundos. Porém bolsões de ar podem se formar e permanecer no solo depois que o sistema é desligado, esses bolsões ficam imóveis e podem permanecer mais do que 72 horas segundo estudos realizados por Elder e Benson (1999).

\subsection{Algumas modificações do sistema convencional de injeção de ar}

O sistema de injeção de ar tem sido utilizado com sucesso na remoção de uma ampla variedade de contaminantes voláteis e semi-voláteis, incluindo gasolina, diesel e outros combustíveis. Essa variedade tem ficado cada vez maior devido às modificações que vem sendo feitas no sistema tradicional de injeção de ar. Algumas modificações feitas com sucesso são: recuperação de vapor por trincheiras e em poços.

\subsubsection{Recuperação de vapor por trincheiras}

Esse método é utilizado quando se tem um perfil de solo com a seguinte formação: argila logo abaixo do nível d'água e em seguida areia ou cascalho, como pode ser visto na Figura 3.8. 


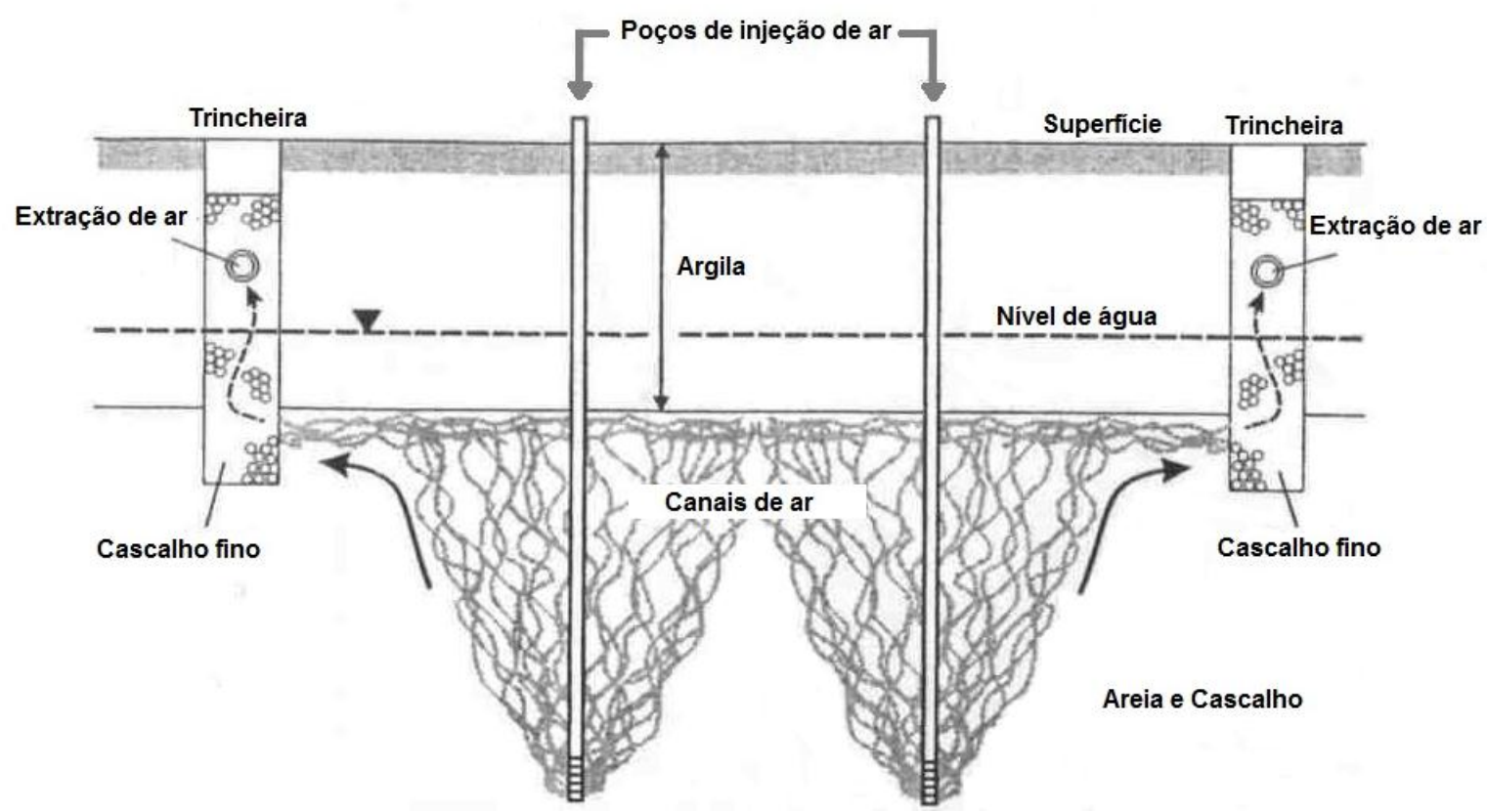

Figura 3.8 - Trincheiras (adaptado de Suthersan (1997))

O transporte de massa na zona saturada e as taxas e mecanismos de remoção são muito similares ao do método convencional, exceto pelas trincheiras. Essas trincheiras são compostas por cascalho com grãos pequenos e arredondados. Podem ser usadas uma ou mais trincheiras paralelas, que são instaladas perpendicularmente ao fluxo da água subterrânea. E também é necessária a utilização do método de SVE instalado nas trincheiras. Segundo Suthersan (1997) essa modificação é muito eficiente quando apenas contaminantes na fase dissolvida precisam ser realocados.

\subsubsection{Em Poços}

A injeção de ar em poços é feita através da injeção de ar sobre pressão dentro de um determinado poço a certa profundidade. O ar não é forçado a entrar no solo, sendo injetado no fundo do poço criando aeração na água do poço. A Figura 3.9 ilustra o processo. 
Capítulo 3 - Características da técnica de injeção de ar

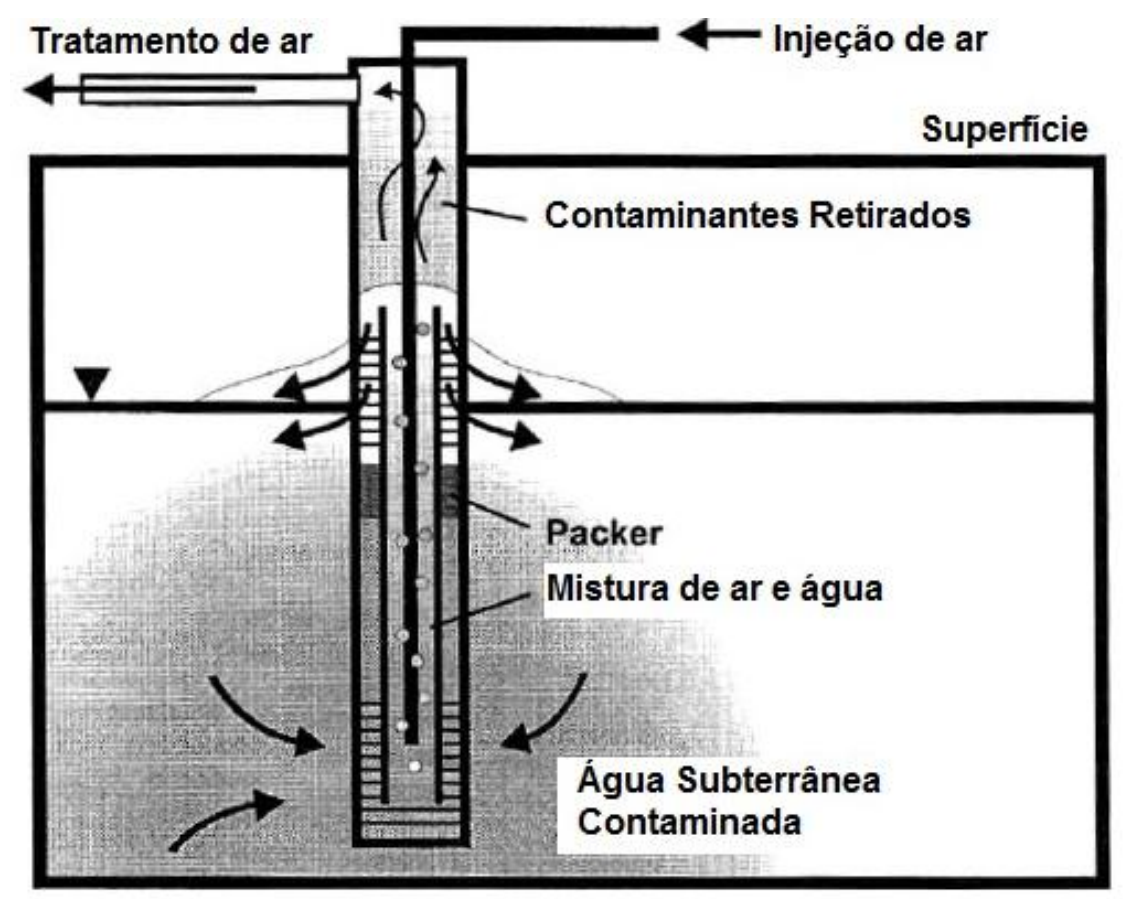

Figura 3.9 - Injeção de ar em poços (adaptado de Suthersan (1997))

Essa modificação supera as limitações do sistema convencional quando aplicado a uma formação geológica não permeável, quando se tem pouca profundidade da água subterrânea e pequena espessura do aqüífero. Para argilas a injeção de ar em poços geralmente tem um desempenho melhor do que o método convencional. 


\section{Capítulo 4}

\section{Padrão do Fluxo de ar em Modelos Físicos}

\subsection{Canais de ar}

A geometria e as características de fluxo estão relacionadas com o tamanho dos grãos e dos poros do solo. Com base na literatura verificou-se que o tipo de fluxo de ar pode ser através de:

- bolhas (também conhecido como fluxo difuso);

- canais discretos (ou simplesmente canais de ar);

- fluxo segmentado lento (slug);

- fluxo contínuo (pequena variação na saturação de ar ao longo da zona de influência sem que haja regiões de completa saturação de água);

- fluxo em câmara;

- fluxos mistos (que seria uma combinação dos tipos de fluxo).

Em ensaios de laboratório Ji et al. (1993) e Baker e Benson (2007) observaram que o regime do fluxo depende do tamanho dos grãos, aparentemente fluxos em bolhas acontecem para partículas maiores que $4 \mathrm{~mm}$ de diâmetro (cascalho), e fluxo em canais ocorre para partículas menores que $0,75 \mathrm{~mm}$ de diâmetro (areia, silte e argila); a transição do fluxo ocorre para partículas de $2 \mathrm{~mm}$.

Segundo Clayton (1998) os mecanismos de formação dos canais de ar são divididos em duas categorias: canais macroscópicos ou ramificações (viscous fingering) e canais de poro dominados pela capilaridade. Durante a injeção o ar migra pelo solo através de caminhos de menor resistência. Os canais macroscópicos são caracterizados pelo seu amplo espaçamento e se formam em solos grossos, como por exemplo, cascalhos. Já os canais de poro têm a largura de uma ou algumas partículas e são formados bem próximos uns dos outros, esse tipo de mecanismo de formação ocorre em areias. 
Na Figura 4.1 podem ser observados esses dois modelos conceituais para o fluxo de ar, estudados por Clayton (1998). Na Figura 4.1-(a) tem-se o modelo de fluxo por canais macroscópicos, devido ao grande espaçamento entre os canais de ar ocorrem regiões entre eles em que o solo se encontra completamente saturados por água. Já na Figura 4.1-(b) encontra-se o outro modelo que é o de fluxo contínuo que é uniformemente distribuído em uma região de variação suave da saturação de ar $\left(\mathrm{S}_{a}\right)$. É esse segundo modelo que é usado na parametrização das simulações de fluxo multi-fásico feita por Lundegard e Andersen (1996).

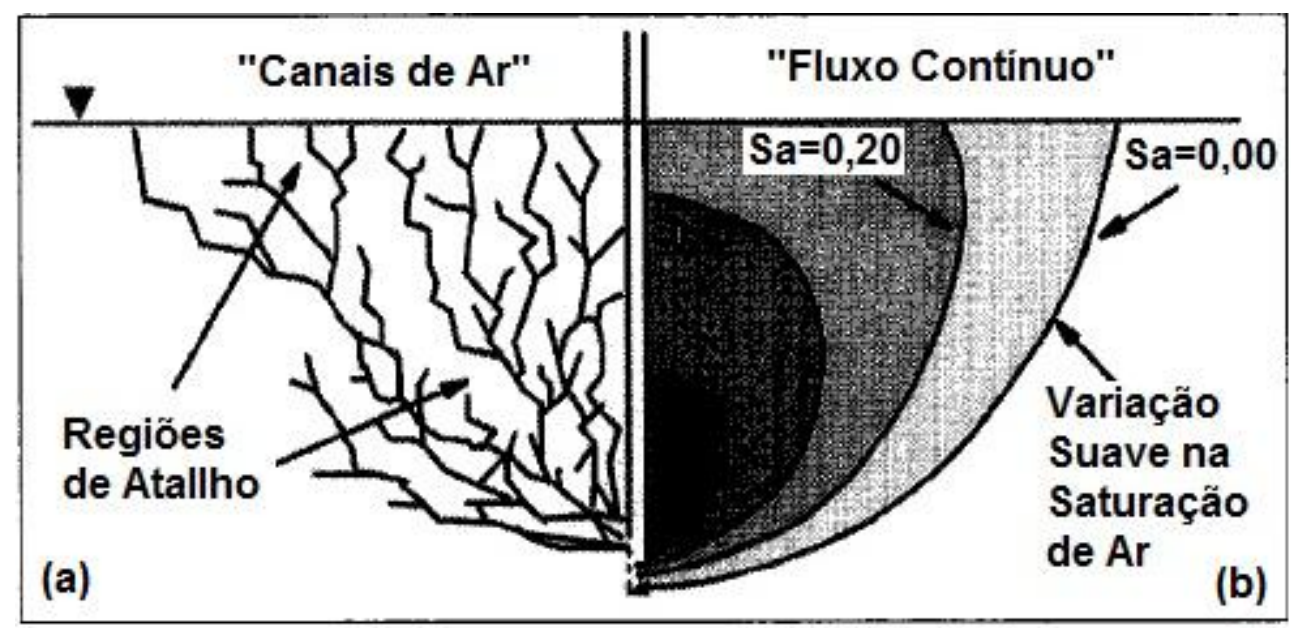

Figura 4.1 - Dois modelos conceituais possíveis para o fluxo de ar durante a injeção, (a) Canais de Ar e (b) Fluxo Contínuo (adaptado de Clayton (1998))

Clayton (1998) concluiu em seus estudos que a pressão capilar tende a permanecer perto da pressão de entrada de ar em muitos casos, indicando o desenvolvimento dos canais do poro (escala do poro). O desenvolvimento de canais macroscópicos é resultado de uma elevada pressão capilar que reflete a saturação dentro do poro.

Resultados de testes experimentais feitos por Clayton (1998) indicaram que o mecanismo de formação de canais é diferente em areia grossa e areia fina, como pode ser visto na Figura 4.2 que mostra o modelo conceitual para o fluxo de ar em um solo homogêneo e isotrópico. Ainda na Figura 4.2 pode se notar que para $S_{a}<0,10$ é prevista a formação de canais macroscópicos de ar o que não ocorre para $S_{a}>0,10$. Nas areias finas uma grande região do fluxo de ar é desenvolvida com saturações de ar maiores que 0,10 ; já nas areias grossas isso acontece somente 
perto do ponto de injeção; isto está relacionado com a curva de retenção de água do solo.

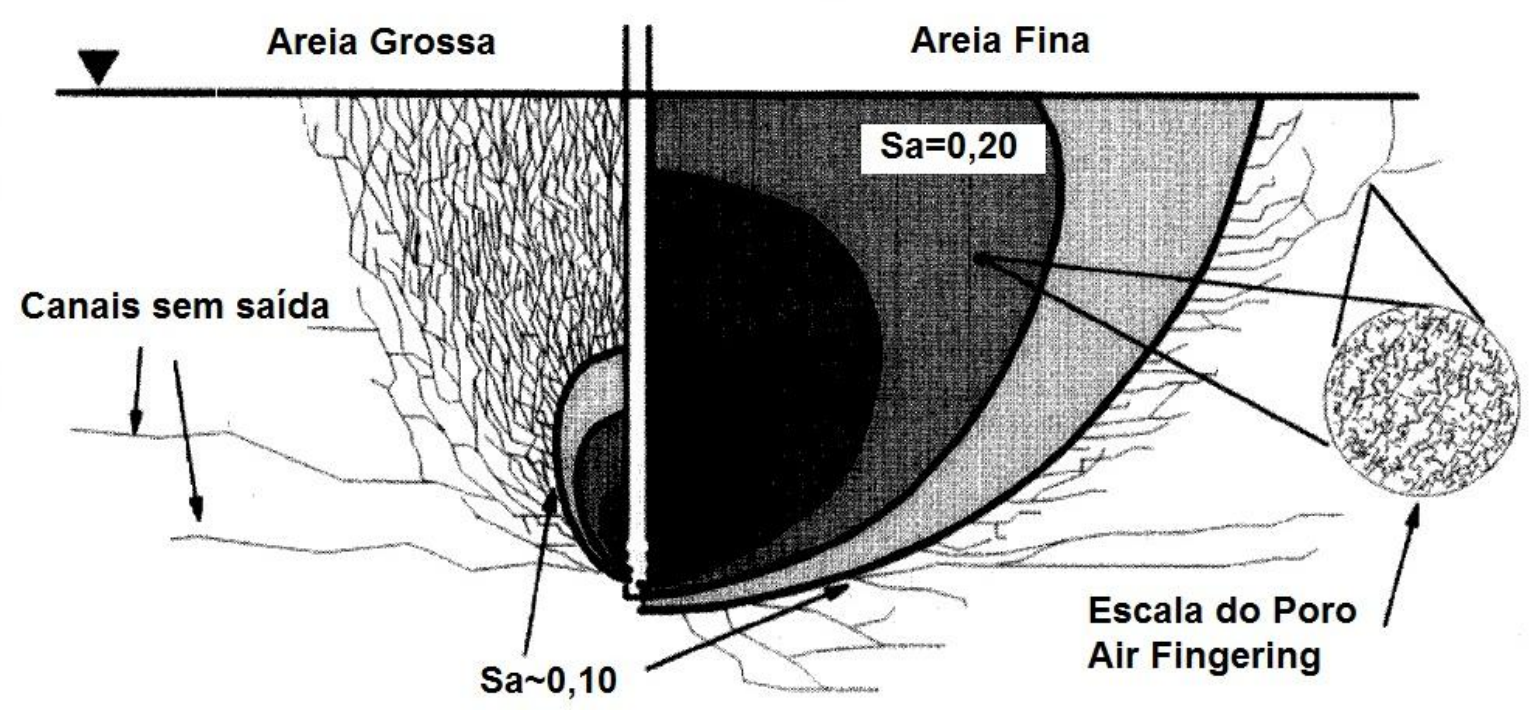

Figura 4.2 - Modelo conceitual mais detalhado para o fluxo de ar durante a injeção, comparação entre areia grossa e fina (adaptado de Clayton (1998))

Areias grossas são mais propensas a terem canais macroscópicos de ar enquanto que areias médias a finas apresentam altas saturações de ar e não apresentam canais macroscópicos de ar.

Peterson et al. (2001) em seus estudos perceberam uma nova geometria do fluxo de ar que resolveram chamar de fluxo em câmara (chamber flow), sendo suas características principais: componente horizontal significante, fluxo de ar difuso, limites de contorno irregulares, presença predominante de canais verticais de entrada e saída. Pode-se entender este modelo observando a Figura 4.3 onde a injeção de ar é feita através de um difusor localizado no centro da base do tanque.

O fluxo em câmara é diferente do fluxo por canais encontrados em outros estudos, o primeiro ocorre em solos com partículas de 0,18 a 0,20 mm e o segundo em partículas maiores. O fluxo em câmara apresenta um volume bem maior de canais de ar do que o esperado para o fluxo por canais. 
Por causa da irregularidade do fluxo de ar em câmara, tanto em termos de forma como de freqüência, é necessário um conhecimento detalhado da estratificação do solo para uma maior eficiência de remediação em locais onde haja a formação de fluxo em câmara.
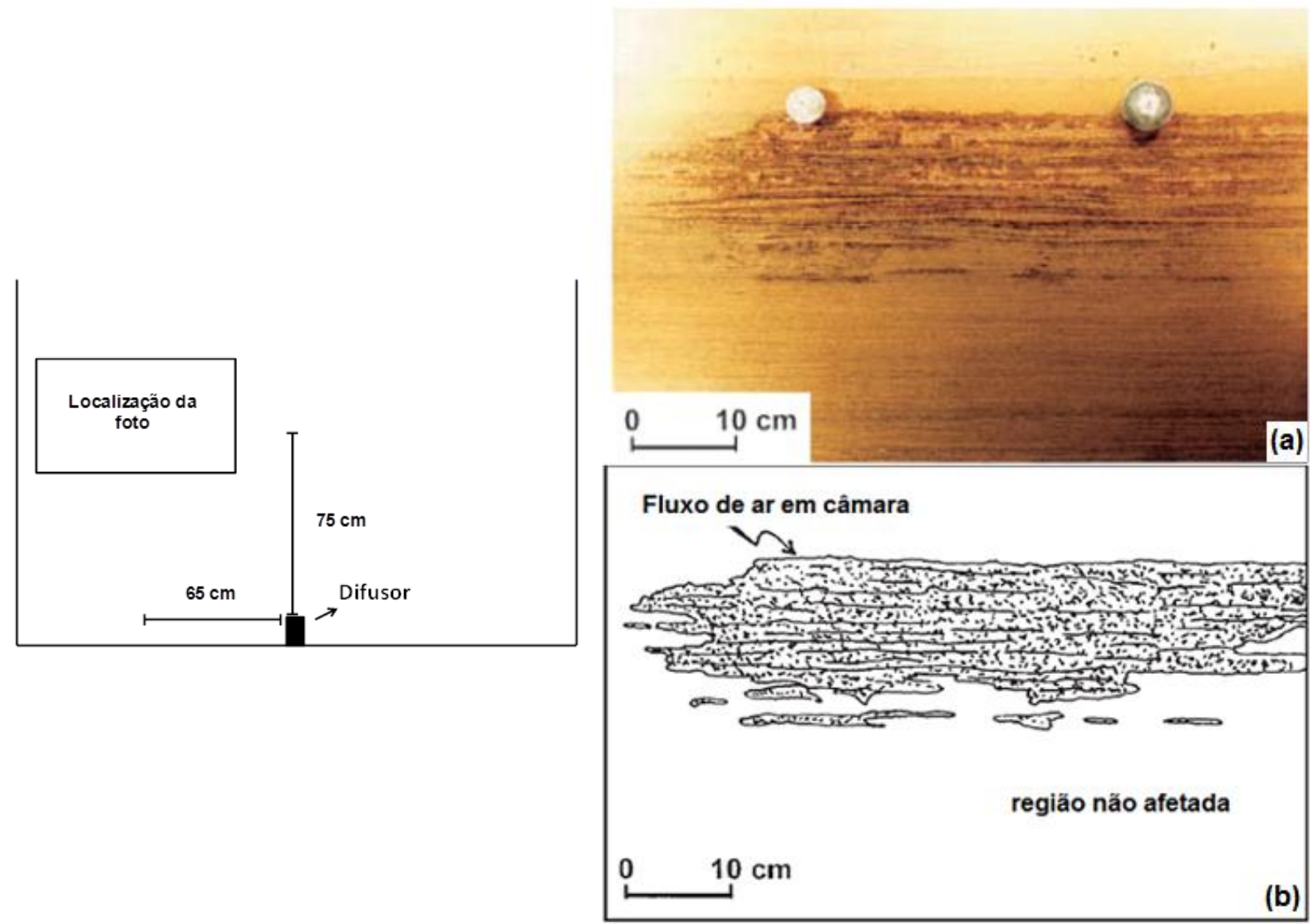

Figura 4.3 - Fluxo em câmara em areia após 113 horas de injeção de ar em (a) pode ser vista a foto do experimento e em (b) um desenho do fluxo de ar (adaptada de Peterson et al. (2001))

\subsection{Testes Piloto em Laboratório}

Os resultados dos estudos em laboratório são essenciais para um melhor entendimento do método de injeção de ar ou qualquer outro método de remediação. Nos estudos de laboratório do método de injeção de ar, são usados geralmente tanques bem finos para a visualização do fluido (fenômeno bidimensional), ou seja, duas dimensões extensas e uma estreita, pois em tanques largos (fenômeno tridimensional) $\mathrm{o}$ ar não pode ser visto a não ser que chegue à superfície ou nas 
paredes do tanque. As paredes do tanque, por se encontrarem muito próximas, sem dúvida podem afetar o tamanho e a forma do raio de influência, mas esse tipo de estudo é necessário para a visualização dos canais de ar. Com este tipo de estudo é possível se ter uma avaliação qualitativa do fluxo.

Elder e Benson (1999) notaram que os canais de ar tinham diâmetros muito menores do que a largura do tanque, o que permitiu que o ar fluísse livremente pelo solo sem ser afetado pelas paredes do tanque, ou seja, a formação dos canais de ar não foi influenciada pelo fato do modelo utilizado ser bidimensional.

Vários autores como, por exemplo, Baker e Benson (2007), Brooks; Wise e Annable (1999), Elder e Benson (1999) e (Jl, et al. 1993) usaram bolinhas de vidro ao invés de solo em seus estudos, pois a transparência auxilia na visualização do fluxo. Segundo Elder e Benson (1999) e Ji et al. (1993) ensaios com solo natural são difíceis de serem realizados, pois o solo é muito opaco, o que impede a visualização dos canais de ar.

Outros autores como Chao; Ong e Huang (2008), Peterson et al. (2001), Peterson; Lepczyk e Lake (1999) e Reddy e Adams (2001) utilizaram tanques com areia para a visualização dos canais de ar, Chao et al. (2008) usou um equipamento de raios- $\mathrm{X} e$ Peterson et al. $(1999,2001)$ usaram limalha de ferro de modo a permitir a visualização do fluxo por meio da mudança de cor da limalha.

A técnica de visualização por coloração consiste na mudança de cor da limalha de ferro de preto para marrom alaranjado através da oxidação do ferro, para isso tem que se usar água desoxigenada para saturar o solo. Durante o ensaio o oxigênio é fornecido para a limalha de ferro exclusivamente através da injeção de ar, é por isso que nos locais onde os caminhos de ar são formados no solo é que a cor da limalha de ferro é alterada. Peterson; Lepczyk e Lake (1999) usaram em seus ensaios a relação de 1 (ferro):7(solo) em volume para os ensaios de coloração através da mudança de cor do ferro.

Para conduzir os ensaios bidimensionais com limalha de ferro o solo foi colocado no tanque simultaneamente com a água desoxigenada, para formar uma coluna de solo 
saturado. Antes dos ensaios, ou seja, da injeção de ar; a limalha de ferro estava em contato apenas com o solo e a água sem oxigênio. Durante o ensaio, o oxigênio é fornecido para o ferro através da injeção de ar, mas inicialmente isso ocorre apenas nos lugares onde os caminhos de ar são formados. Para que a água ficasse sem oxigênio ela foi fervida durante 5 minutos antes de ser usada nos experimentos. A limalha de ferro utilizada possuía a mesma granulometria do solo em estudo. Segundo PETERSON; LEPCZYK e LAKE (1999) este método provou ser eficiente na observação da localização e geometria da zona de influência. O tempo de injeção necessário para que se possa ocorrer oxidação do ferro é aproximadamente 12 horas.

O uso de limalha de ferro descrito acima pode não ser um método de visualização muito adequado, pois a presença de ferro dissolvido $\left(\mathrm{Fe}^{+2}\right)$ pode reduzir a permeabilidade da zona saturada durante a injeção de ar, pois quando o ferro dissolvido entra em contato com o oxigênio ele oxida se transformando em ferro insolúvel $\left(\mathrm{Fe}^{+3}\right)$ que pode precipitar dentro da zona saturada obstruindo alguns poros, reduzindo assim a região de fluxo de ar fazendo com que a permeabilidade diminua. Em campo o mesmo problema pode ocorrer se houver $\mathrm{Fe}^{+2}$; e a oxidação ocorre geralmente perto do poço de injeção que às vezes por causa disso precisa ser trocado e instalado em outro local. A Tabela 4.1 apresenta alguns valores da concentração de ferro dissolvido que podem ser prejudiciais ao método.

Tabela 4.1 - Concentrações de ferro dissolvido que podem atrapalhar a injeção de ar (adaptado de EPA (1994))

\begin{tabular}{cc}
\hline Concentração de ferro dissolvido $(\mathrm{mg} / \mathrm{L})$ & Eficiência da injeção de ar \\
\hline $\mathrm{Fe}^{+2}<10$ & Eficiente \\
$10 \leq \mathrm{Fe}^{+2} \leq 20$ & Poços de injeção necessitam de testes e \\
$\mathrm{Fe}^{+2}>20$ & podem precisar ser repostos \\
\end{tabular}

Plummer; Nelson e Zumwalt (1997) realizaram estudos em um tanque com bolinhas de vidro e com areia separadamente, os dois materiais tinham as mesmas distribuições granulométricas, e o fluxo era bastante diferente pelos dois meios, 
mostrando assim que as bolinhas de vidro não são um material adequado para simular o fluxo de ar através de solo natural.

Nos ensaios realizados por $\mathrm{Ji}$ et al. (1993) os canais contínuos de ar crescem conforme a vazão é aumentada, mas o tamanho dos canais continua praticamente o mesmo, apenas surgem mais canais, isso pode ser visto nas Figura 4.4-(a) e Figura 4.4-(b). Aqui também pode ser observado o que foi discutido anteriormente sobre a forma da zona de influência sendo de um $V$ para baixas pressões (Figura 4.4-(a)) e de U para altas pressões (Figura 4.4-(b)).

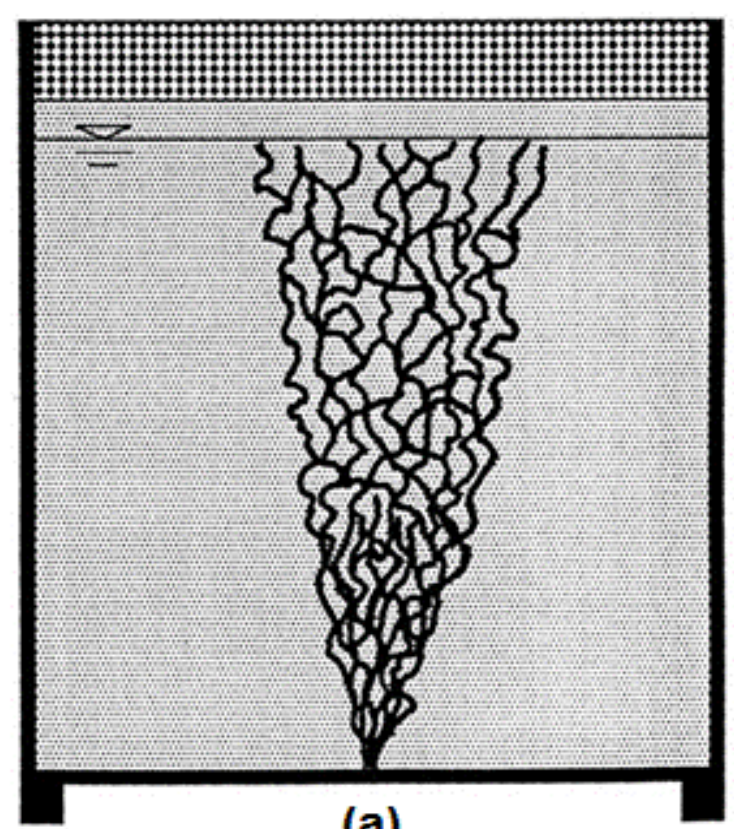

(a)

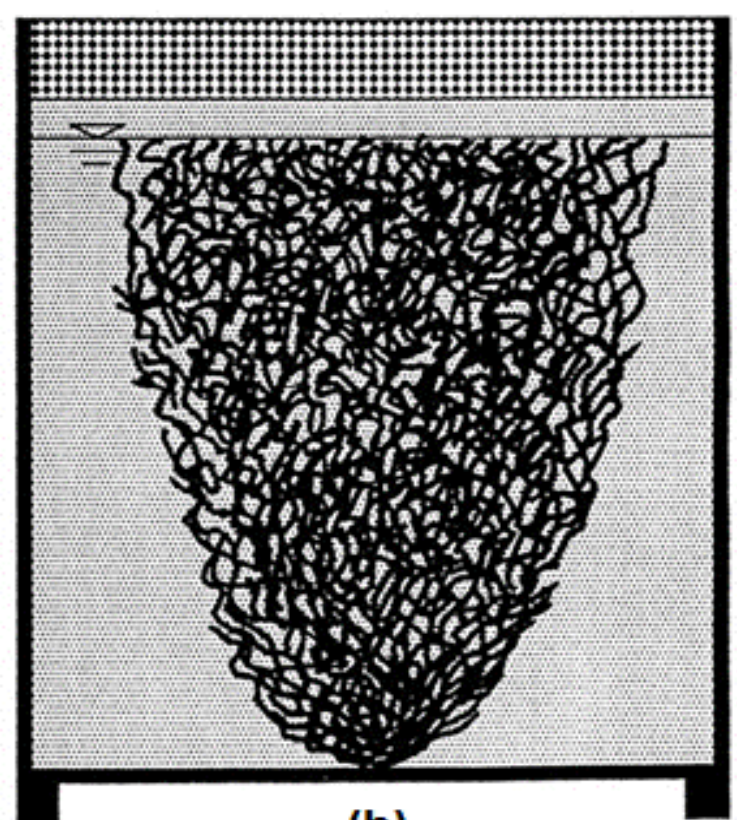

(b)

Figura 4.4 - Desenhos dos canais de ar com vazão moderada em (a) e alta em (b) para partículas de $0,75 \mathrm{~mm}$, ensaio realizado em bolinhas de vidro (Ji et al. (1993)))

Já os ensaios realizados por Chao; Ong e Huang (2008) mostraram que com o aumento da vazão novos canais de ar são formados dentro da zona de influência e que os canais de ar ficam mais largos, para areias finas. Nas areias grossas não foi notada muita diferença no tamanho das bolhas.

\subsection{Condições dos solos}

As características geológicas do subsolo são muito importantes para o método de injeção de ar, pois são elas que regem a utilização do método. As condições do solo 
afetam o tamanho da zona de influência, a densidade de canais de ar e governam a probabilidade de sucesso da remediação. Esse método funciona melhor em solos de granulometria média a mal graduada (que possuem grandes vazios); com alta permeabilidade e homogêneos, o que permite um contato eficiente entre 0 ar introduzido e os contaminantes presentes.

A utilização do método em solos finos (siltes ou argilas) requer uma alta pressão de injeção, pois há uma tendência de bolhas de ar ficarem presas nos poros nesse tipo de solo. Também ocorre uma maior migração lateral em solos finos.

Variações de permeabilidade no solo, mesmo que pequenas, podem influenciar o movimento do ar e criar caminhos preferenciais. Simulações feitas por Lundegard e Andersen (1996) mostraram que a permeabilidade vertical e a anisotropia do solo são variáveis muito importantes, a relação entre a permeabilidade vertical e a horizontal afeta o fluxo dos caminhos de ar do ponto de injeção até o lençol freático. $O$ ar injetado se espalha lateralmente quando alcança a zona não saturada, pois a permeabilidade horizontal tipicamente excede a permeabilidade vertical. A entrada do fluxo de ar no solo é função da variação na permeabilidade e estrutura do solo, estratificação e pressão de injeção.

Em solos heterogêneos e estratificados o caminho e movimento do ar para a zona não saturada é complexo, dependendo das variações no tamanho dos grãos, da pressão de entrada de ar da permeabilidade intrínseca do solo entre outros fatores. Segundo Lundegard e Labrecque (1995) o aumento da anisotropia do aquífero pode causar um aumento no tamanho da zona de influência.

\subsubsection{Heterogeneidade e Anisotropia}

$\mathrm{Na}$ natureza a heterogeneidade é mais comum do que a homogeneidade devido ao processo natural de formação do solo que resulta em deposições não uniformes dos sedimentos que irão formar o solo.

A heterogeneidade tem um grande impacto na forma do raio de influência e na saturação de ar. O método de injeção de ar é mais eficiente quando aplicado em 
solos homogêneos e granulares, que dificilmente ocorrem naturalmente na natureza, por isso que as visualizações do fluxo de ar em tanques, que simulam solos homogêneos, podem levar a resultados diferentes dos encontrados em campo.

Materiais mais heterogêneos ou anisotrópicos aumentam o espalhamento lateral do raio de influência, o que pode fazer com que a zona de influência deixe de ser simétrica. Esse espalhamento pode ser causado por mudanças na densidade ou mudanças repentinas no tamanho das partículas do material. Quanto mais heterogêneo ou anisotrópico for o solo, maior é a probabilidade de insucesso na remoção dos contaminantes.

A presença de lentes de baixa permeabilidade, como siltes ou argilas, também interferem na aplicação do método, pois podem impedir a passagem vertical do ar, possibilitando ainda aprisionamento de bolhas de ar nos vazios próximos as lentes. Como pode ser visto na Figura 4.5-(a) o fluxo de ar é interrompido ao chegar às lentes e se move lateralmente, até passar pelo lado da lente continuando a subir, como ilustrado na Figura 4.5-(b). Esta figura também mostra que a região logo acima das lentes fica isolada dos canais de ar. As lentes só são penetradas pelo ar quando se tem uma injeção de ar muito alta, como na Figura 4.5-(c).

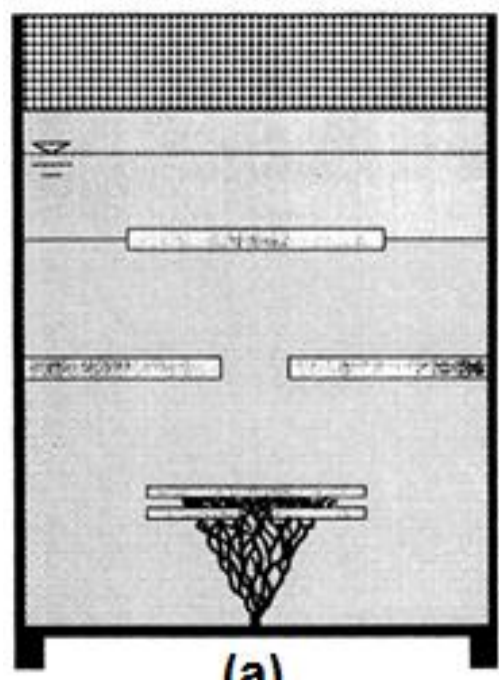

(a)

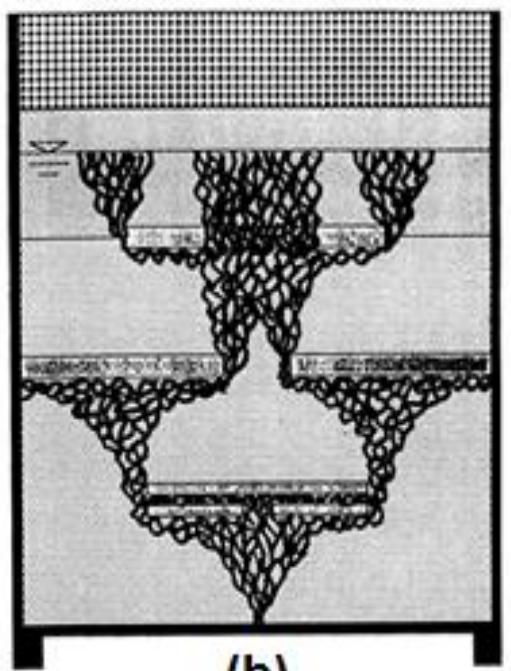

(b)

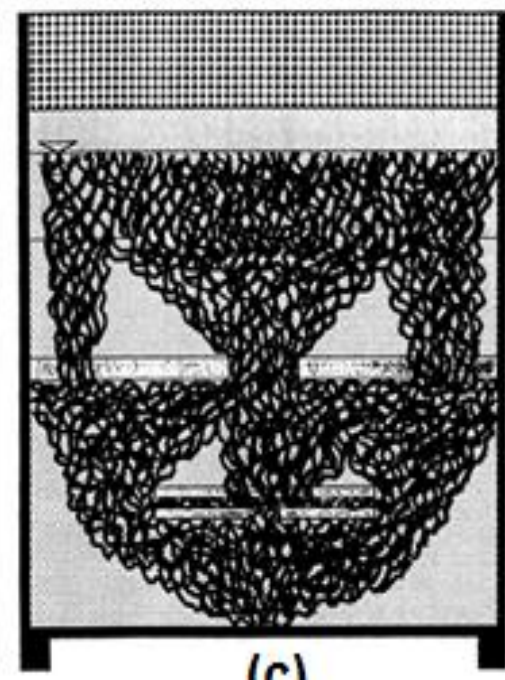

(c)

Figura 4.5 - Desenhos esquemáticos dos canais de ar em um modelo com bolinhas de vidro que simulam lentes de baixa permeabilidade (Jl et al., 1993) 
Segundo Johnson et al. (1993) o movimento lateral do ar observado na Figura 4.5(b) continua até a pressão exceder a pressão de entrada de ar da lente de baixa permeabilidade, ou até atingir um caminho vertical como um poço de monitoramento ou uma fratura.

Lentes de alta permeabilidade também representam um problema, pois fazem com que $o$ ar se mova lateralmente pela lente podendo causar um aumento da pluma de contaminação, ou seja, ocorre um aumento da área contaminada. Em solos altamente estratificados, o ar pode se movimentar para longe dos poços de injeção antes de atingir a zona não saturada, podendo não atingir as áreas contaminadas. Por isso que para solos homogêneos a aplicação do método de injeção de ar é mais satisfatória e tem maior probabilidade de sucesso.

\subsubsection{Tamanho das partículas}

Solos mal graduados que possuem baixa pressão de entrada de ar (e.g. solos arenosos) tem altas saturações de ar. É por isso que em solos grossos o tratamento é mais rápido. Como o raio de influência é menor em tais solos, mais poços de injeção são requeridos. Baker (1996) apud Baker e Benson (1996) ensaiando com bolinhas de vidro mostrou que para todas as pressões, grandes saturações de ar são obtidas em "grãos" maiores.

Como a pressão de ar aumenta, o ar entrará nos poros com a menor pressão capilar. Conforme já mencionado anteriormente a pressão de injeção depende da pressão capilar, ver equação (3.4). O segundo termo desta equação é a equação de Laplace.

Pode-se notar que menores pressões capilares irão ocorrer em solos com poros maiores, ou seja, os canais de ar irão preferir se formar em poros grandes, conforme ilustra a Figura 4.6. 


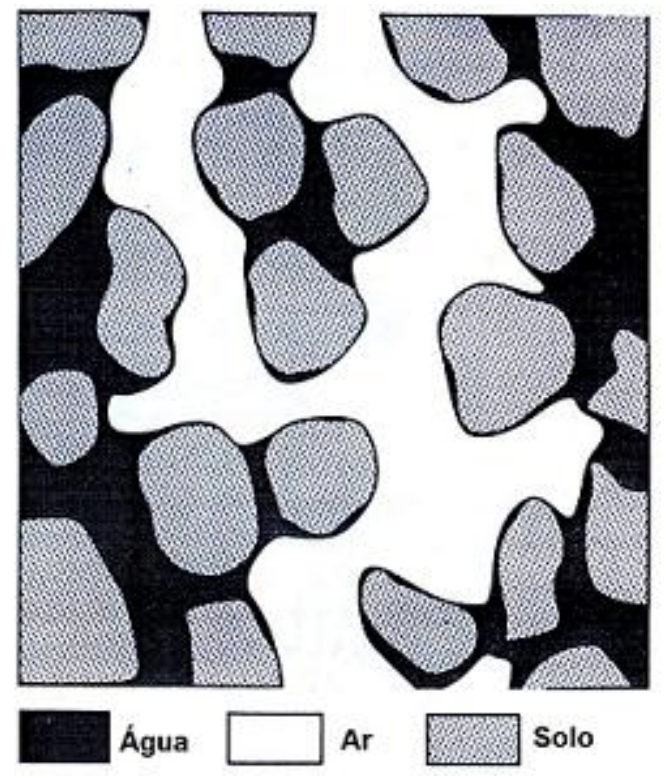

Figura 4.6 - Esquema de canais de ar mostrando a interface entre ar e água (adaptado de (AHLFELD; DAHMANI; Jl, 1994))

Elder e Benson (1999) em seus estudos de laboratório com um modelo bidimensional usando bolinhas de vidro concluíram que em areias grossas os canais de ar formados são mais estreitos e mais tortuosos, tem uma alta densidade de canais de ar próximo ao ponto de injeção e se movem quase que verticalmente; já em areias finas os canais de ar têm grandes diâmetros, são mais espaçados (baixa densidade de canais) e se movem quase que horizontalmente no solo.

Segundo Peterson; Lepczyk e Lake (1999) solos com diâmetros entre 2 a $3 \mathrm{~mm}$ tiveram um melhor desempenho em estudos realizados em um tanque transparente, pois a zona de influência formada foi maior.

Estudos realizados em laboratório nos tanques têm mostrado que a geometria e a distribuição do fluxo de ar (zona de influência) dependem principalmente do tamanho dos grãos do solo em estudo.

\subsection{Geometria do fluxo de ar}

Chao; Ong e Huang (2008) mostraram que o fluxo se dá através de bolhas para areias grossas $\left(D_{50}=1,7 \mathrm{~mm}\right)$ e por meio de canais de ar de diferentes tamanhos 
para areias finas $\left(D_{50}=0,4\right)$. Entretanto a forma da zona de influência é a mesma para os dois tipos de solo, ou seja, a forma de um $\mathrm{V}$ (cone) para baixas vazões. Não foram feitos ensaios para altas vazões.

Lundegard e Andersen (1996) em seus estudos de modelagem encontraram que a forma da zona de influência era em "U" com a base perto do ponto de injeção.

Brooks; Wise e Annable (1999) também realizaram estudos em tanques com bolinhas de vidro e seus resultados mostraram que o fluxo por meio de canais de ar ocorre para grãos com diâmetros médios iguais ou menores do que 1 a $2 \mathrm{~mm}$; e fluxo em bolhas ocorre em solos com grandes poros. Eles também descrevem que encontraram fluxo por canais, por bolhas, fluxo segmentado lento (slugs) e fluxos misturados. O fluxo por canais é usado para descrever os caminhos quando áreas dentro do solo dessaturam de repente e permanecem não saturados durante a aplicação de pressão. Já o fluxo por bolhas e o segmentado lento (slug) são usados para descrever os caminhos caracterizados pelo movimento de bolhas. Fluxo segmentado lento (slug) é definido como um regime de fluxo não homogêneo caracterizado por porções alternadas de gás e líquido. Esse tipo de fluxo é parecido com o fluxo por bolhas só que as bolhas se movem mais rápido e são maiores. $\mathrm{Na}$ Figura 4.7 pode ser visto em (a) fluxo por bolhas e em (b) fluxo segmentado lento (slug). 
(a)
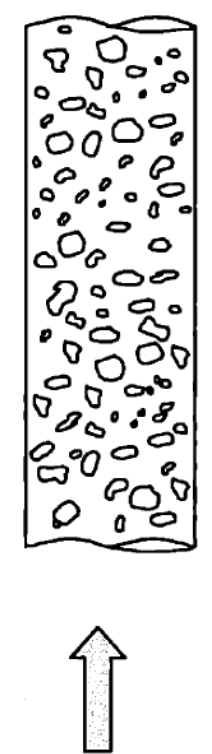

Fluxo por bolhas (b)
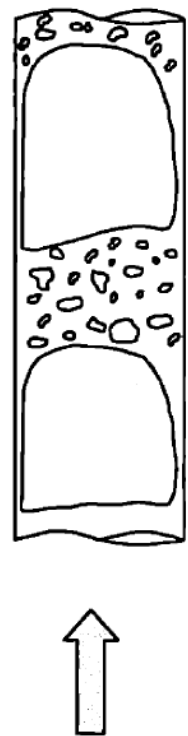

Fluxo slug

Figura 4.7 - Fluxo por bolhas em (a) e fluxo segmentado lento (slug) em (b) (modificado de Marulanda (2001) depois de Taitel, 1980)

Peterson; Lepczyk e Lake (1999) encontram resultados semelhantes aos de Ji et al. (1993); seus resultados mostraram que, para partículas com tamanhos menores do que 1,3 $\mathrm{mm}$ de diâmetro (tamanho médio dos grãos), o fluxo ocorre por canais discretos, e para partículas maiores do que $1,84 \mathrm{~mm}$ de diâmetro o fluxo é difuso (descrito anteriormente como fluxo por bolhas), formando uma área de influência simétrica no entorno do ponto de injeção. Os resultados obtidos nesse estudo podem ser vistos na Figura 4.8. Peterson; Lepczyk e Lake (1999) preferem chamar de fluxo difuso em vez de fluxo por bolhas, porque o termo bolhas implica em certas características físicas como, por exemplo, o formato arredondado associado a elas. 

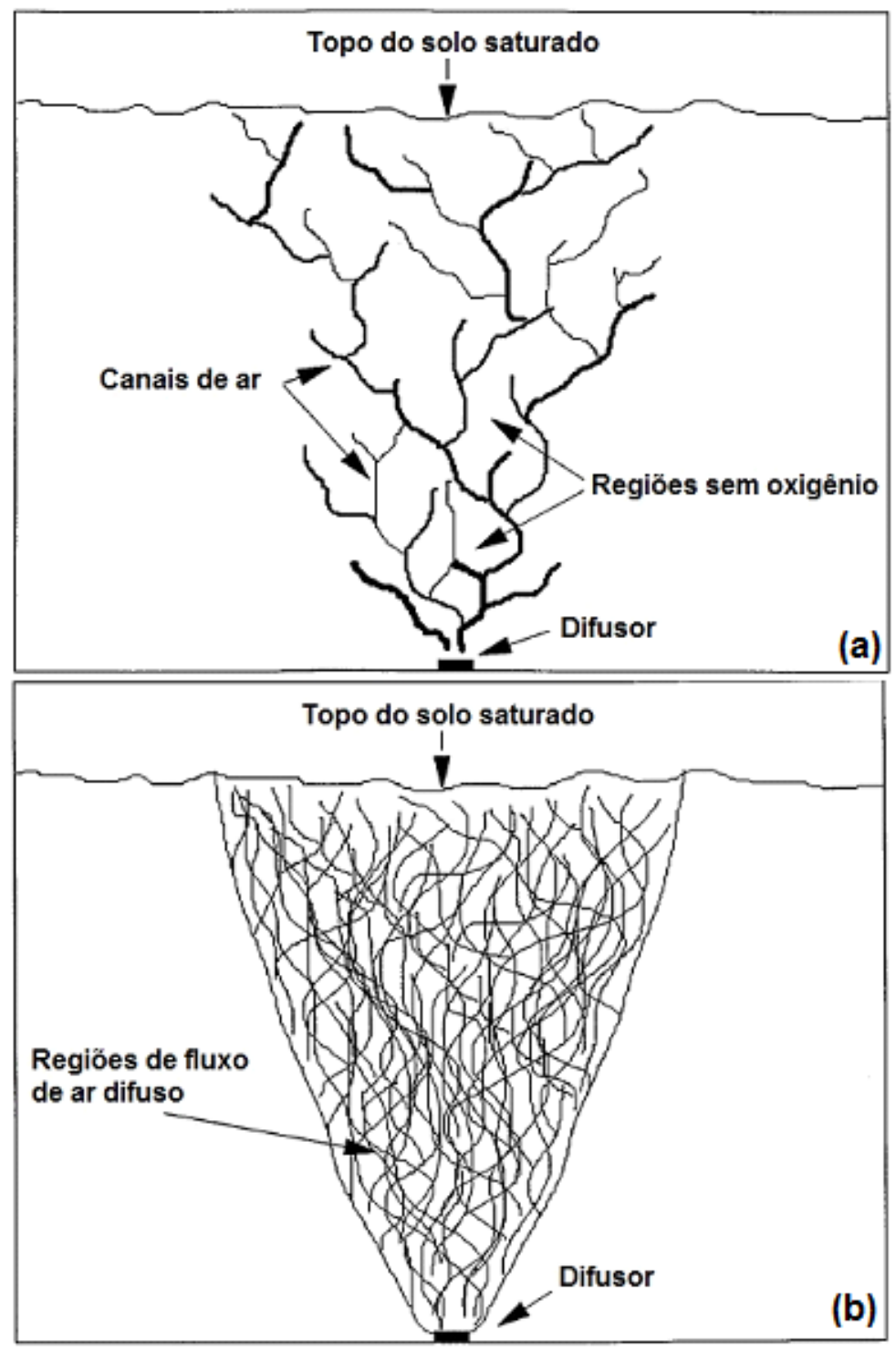

Figura 4.8 - Geometria do fluxo de ar em (a) partículas com diâmetro médio menor que 1,3 mm, fluxo por canais discretos em (b) partículas com diâmetro médio maior que $1,84 \mathrm{~mm}$, fluxo difuso (adaptado de Peterson; Lepczyk e Lake (1999))

Reddy e Adams (2001) usaram solos com vários valores de $D_{50}$ e contaminado com benzeno. O principal objetivo da pesquisa deles foi ver como a heterogeneidade do solo afeta o fluxo de ar e a remediação. Eles fizeram estudos em um tanque bidimensional com cascalho fino $\left(D_{50}=4,5 \mathrm{~mm}\right)$, areia grossa $\left(D_{50}=0,52 \mathrm{~mm}\right) \mathrm{e}$ areia fina $\left(D_{50}=0,12 \mathrm{~mm}\right)$, e como em outros estudos semelhantes eles encontraram o fluxo de bolhas para o cascalho e canais de ar para as areias. A Figura 4.9 mostra o fluxo por canais para areia grossa uniforme (a) e areia bem graduada (b). A geometria do fluxo de ar encontrada para a areia grossa foi parabólica saindo do ponto de injeção (Figura 4.9-(a)). Já o caso da areia bem graduada o formato do 
fluxo de ar é o mesmo da areia grossa só que a zona de influência é bem maior tendo uma expansão lateral como pode ser visto na Figura 4.9 (b). A permeabilidade da areia bem graduada $\left(K_{w}=1,3 \times 10^{-2} \mathrm{~cm} / \mathrm{s}\right)$ é um pouco menor do que a da areia grossa uniforme $\left(K_{w}=4,64 \times 10^{-2} \mathrm{~cm} / \mathrm{s}\right)$, e a porosidade da areia bem graduada $(n=0,35$ e e $=0,54)$ também é mais baixa do que a da areia grossa $(n=0,45$ e e $=0,82)$; acredita-se que o baixo valor da porosidade levou ao aumento da tortuosidade na areia bem graduada e foi isso que causou a migração lateral do ar aumentando a zona de influência. Grandes valores de tortuosidade levam a grandes migrações laterais do ar, gerando assim uma zona de influência maior.
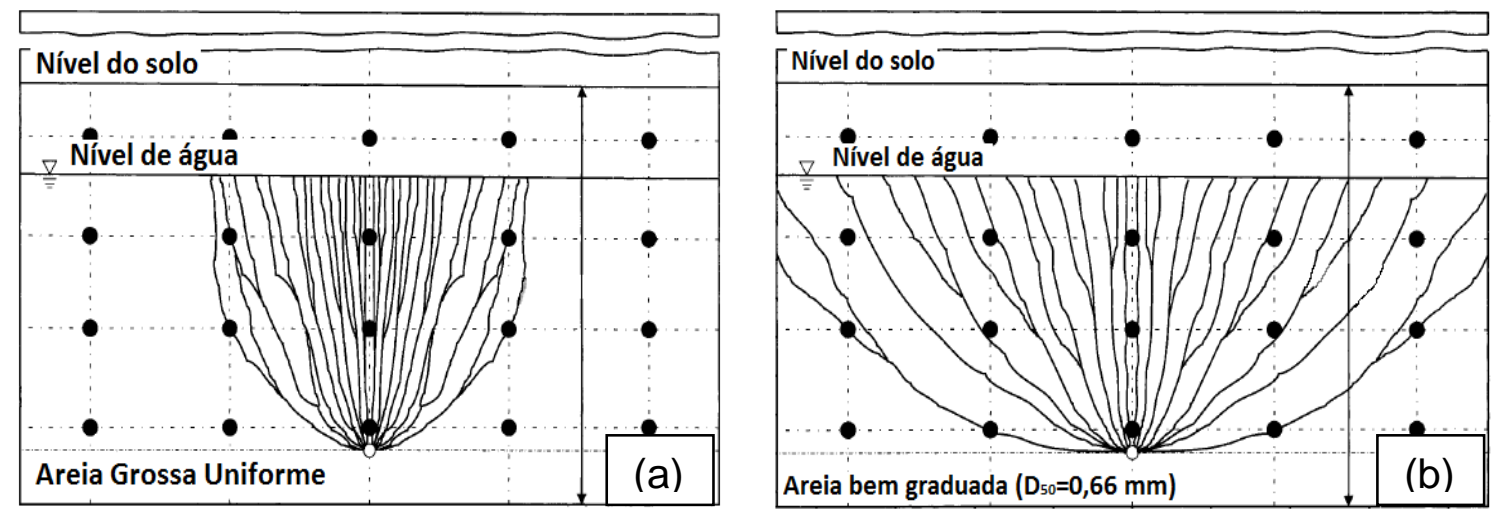

Figura 4.9 - Geometria dos canais de fluxo de ar em (a) areia grossa e (b) areia bem graduada (adaptado de Reddy e Adams (2001))

Uma menor permeabilidade pode levar a um espraiamento da zona de saturação de ar aumentando o efeito da volatilização. A zona de influência é maior na areia bem graduada do que na areia grossa uniforme, mas ambas tem o mesmo volume de fluxo de ar, por essa razão a densidade de canais de ar é menor na areia bem graduada.

Com o objetivo de estudar o efeito da heterogeneidade do solo no fluxo de ar Reddy e Adamn (2001) realizaram um ensaio em um tanque com areia grossa $\left(D_{50}=0,52\right.$ $\mathrm{mm}$ ) no fundo e no topo, e areia bem graduada $\left(D_{50}=0,66 \mathrm{~mm}\right)$ entre as duas camadas de areia grossa, como mostra a Figura 4.10. A forma da zona de influência continua sendo parabólica enquanto os canais de ar percorrem a areia grossa uniforme e quando atingem a areia bem graduada há uma expansão lateral da zona de influência, similar ao que foi visto na Figura 4.9 (a) e (b). Segundo Reddy e 
Adams (2001) perto da interface entre os dois solos, forças capilares e forças gravitacionais têm a mesma magnitude, criando uma zona estreita de interação areia grossa/areia bem graduada na qual o ar injetado migra lateralmente.

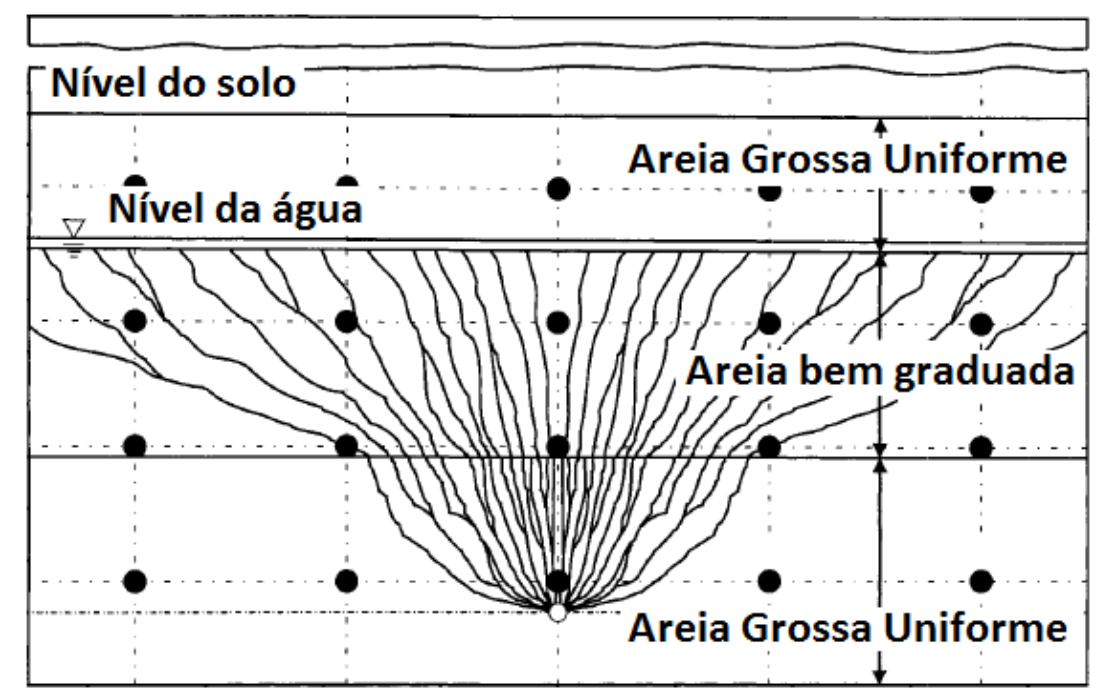

Figura 4.10 - Fluxo de ar em areia bem graduada entre areia grossa uniforme (adaptado de Reddy e Adams (2001))

Reddy e Adams (2001) também fizeram ensaios com cascalho fino $\left(D_{50}=4,5 \mathrm{~mm}\right)$ no fundo e areia grossa uniforme $\left(D_{50}=0,52\right)$ no topo como pode ser observado na Figura 4.11. O fluxo de ar no cascalho fino é em forma de bolhas e não de canais. Quando a injeção de ar começa, uma estreita faixa de fluxo de ar sai do ponto de injeção e sobe sem muita expansão lateral, enquanto o ar migra pelo cascalho fino. Quando o ar atinge a camada de areia grossa ele é desviado e migra lateralmente ao longo da interface dos dois solos, pois a resistência ao movimento é menor na direção horizontal do que na vertical. Isso acontece porque a permeabilidade do cascalho fino $\left(K_{w}=1,6 \mathrm{~cm} / \mathrm{s}\right)$ é muito maior do que a da areia grossa uniforme $\left(K_{w}=4,64 \times 10^{-2} \mathrm{~cm} / \mathrm{s}\right)$. A Figura 4.11 não mostra fluxo na camada de areia grossa, mas os autores afirmam que um fluxo muito pequeno foi percebido na camada de areia grossa. 


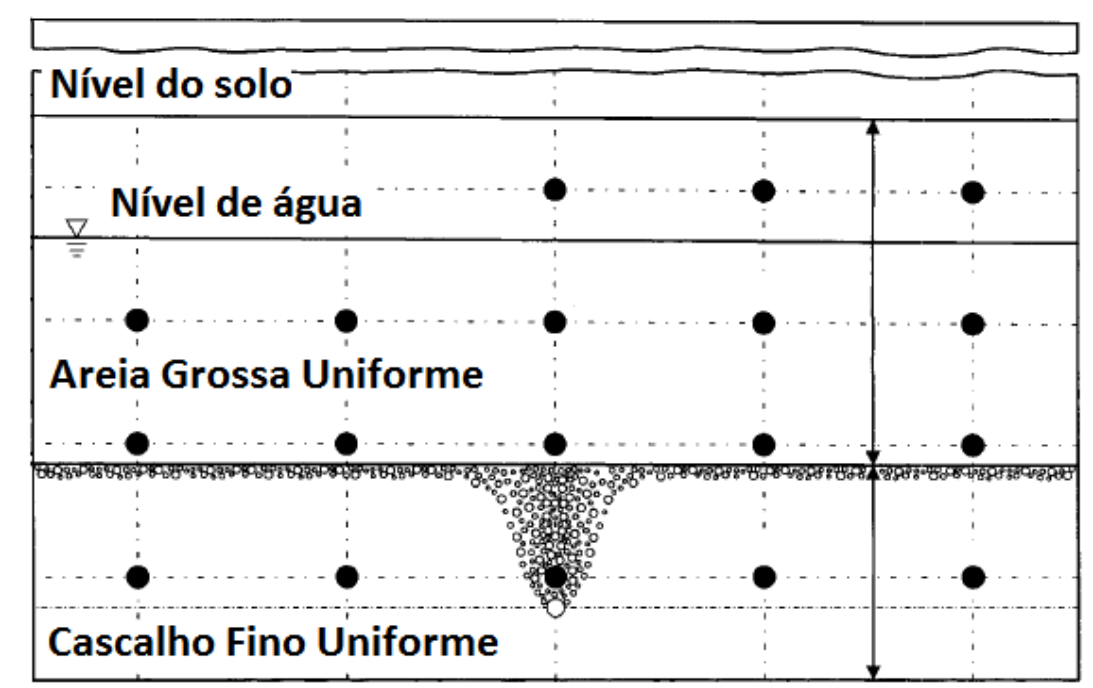

Figura 4.11 - Fluxo de ar em cascalho fino embaixo de areia grossa uniforme (Adaptado de Reddy e Adams (2001))

Peterson, DeBoer e Lake (2000) realizaram estudos em laboratório com solos contaminados com tolueno. Os autores notaram que o tempo de limpeza completa do solo é aproximadamente oito vezes maior em areias do que em cascalhos. Essa diferença de tempo é atribuída à geometria do fluxo de ar que pode ser através de bolhas (cascalho) ou canais (solos arenosos). O fluxo através de bolhas permite um maior contato entre $o$ ar e os contaminantes.

$\mathrm{O}$ ar injetado tem dificuldade de penetrar na areia grossa devido à grande diferença de permeabilidade entre as duas camadas; a permeabilidade horizontal do cascalho fino permite a migração lateral ao invés do fluxo continuar verticalmente.

O fluxo em forma de bolha, encontrado em cascalhos, causa uma remoção mais eficiente do contaminante do que o fluxo por canais encontrado em areias finas. No fluxo por bolhas a remoção é mais eficiente só que exige um número maior de poços de injeção para que a remediação seja satisfatória.

Com o intuito de estudar o efeito de solos estratificados Reddy e Adams (2001) fizeram um ensaio com uma camada de solo de alta permeabilidade (cascalho fino $D_{50}=4,5 \mathrm{~mm}$ ) entre duas camadas de solos de baixa permeabilidade (areia grossa $D_{50}=0,52 \mathrm{~mm}$ ); como pode ser visto na Figura 4.12. A zona de influência formada é parabólica e os canais de ar ficam apenas perto do ponto de injeção sem muita 
expansão lateral. Quando a migração vertical atinge a camada de cascalho fino o fluxo de ar não se dá mais através de canais e sim por bolhas, similar ao que foi observado em ensaios apenas com cascalho fino.

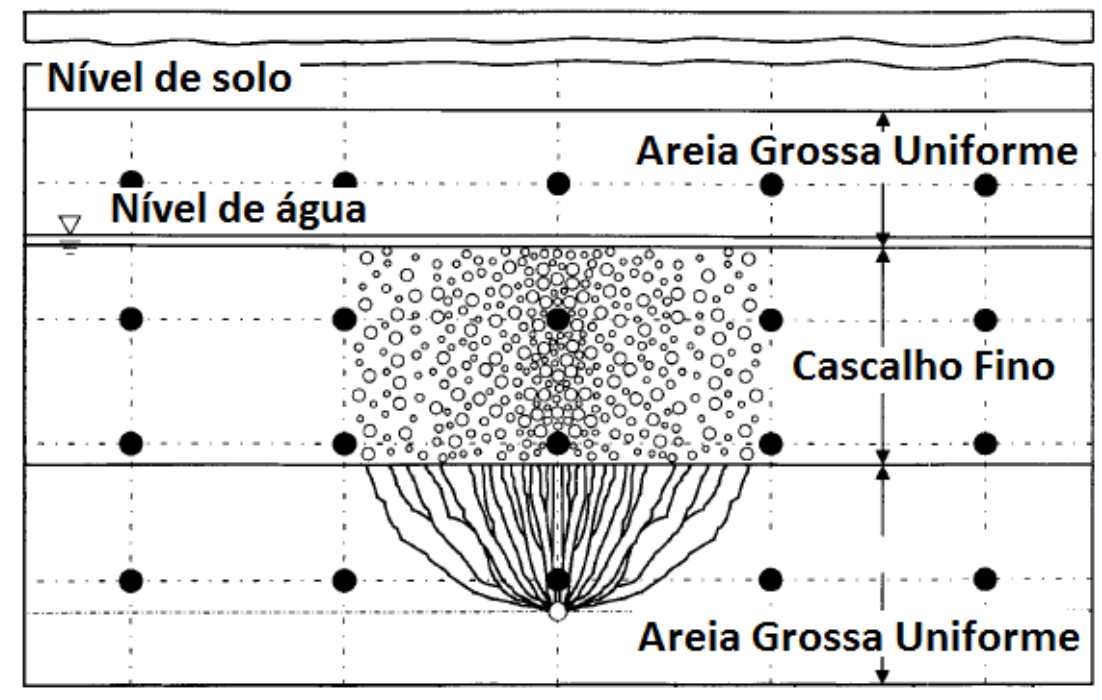

Figura 4.12 - Fluxo de ar em cascalho fino entre duas camadas de areia grossa (adaptado de Reddy e Adams (2001))

O tamanho e a forma dos poros influenciam no tipo de fluxo como foi apresentado anteriormente, e isso pode ser um dos motivos pelos quais Chao; Ong e Huang (2008) e Ji et al. (1993) encontraram resultados diferentes já que foram usados areia e bolinhas de vidro respectivamente.

Vários autores confirmam que provavelmente haja diferenças na geometria do fluxo de ar em solos naturais e bolinhas de vidro devido à irregularidade dos grãos de solo e o arranjo dos mesmos no tanque, isso pode causar efeitos significantes na pressão de entrada de ar e nos caminhos de migração do ar. Estas observações sugerem que mesmo em areias a forma de deposição deve influenciar no padrão de fluxo do ar.

Plummer; Nelson e Zumwalt (1997) encontraram vazões 2,5 a 3 vezes maiores em ensaios com bolinhas de vidro do que nos com areia. $O$ formato esférico das bolinhas de vidro resulta em menos friç̧ão partícula-partícula, produzindo uma menor resistência da passagem do ar injetado e desenvolvendo assim caminhos preferenciais. 
Peterson; Lepczyk e Lake (1999) realizaram estudos em um tanque com as seguintes dimensões $90 \mathrm{~cm}$ de altura, $90 \mathrm{~cm}$ de largura e 2,5 cm de profundidade e notaram que a máxima área afetada pelo fluxo de ar em canais discretos foi de aproximadamente 19\% em 95 horas de injeção, e nesse tipo de fluxo pode-se notar que uma pequena variação no tamanho médio dos grãos tem pouco impacto na área de influência. O fluxo difuso (ou por bolhas) afeta uma área bem maior do que o fluxo por canais discretos como já visto anteriormente na Figura 4.8. A máxima área do tanque afetada foi de aproximadamente $35 \%$ em 142 horas para partículas de diâmetro médio de 2,61 mm.

Estudos realizados por Peterson; Lepczyk e Lake (1999) indicaram que não há relação direta entre o tamanho médio dos grãos e a máxima porcentagem da área afetada quando o fluxo é difuso.

A distribuição granulométrica, grãos de areia angulares, o arranjo das partículas e a compactação afetam o tamanho do poro que afeta o tipo de fluxo. Solos bem graduados se comportam como solos de partículas finas; em termos de padrão de fluxo; pois os grãos pequenos ocupam os vazios entre os grãos grandes diminuindo assim os poros. O tamanho dos poros que geralmente pode ser associado ao tamanho do grão, rege o primeiro passo para se determinar os caminhos do fluxo.

O ensaio realizado por $\mathrm{Ji}$ et al. (1993) com uma mistura de dois tamanhos de bolinhas de vidro, (38\% de $0,75 \mathrm{~mm}$ e $62 \%$ de $0,3 \mathrm{~mm}$ ) a uma baixa vazão $(0,6$ $\mathrm{L} / \mathrm{min}$ ) é apresentado na Figura 4.13 , indicando que a pluma formada não foi parabólica e alguns canais de ar se moveram diagonalmente. 


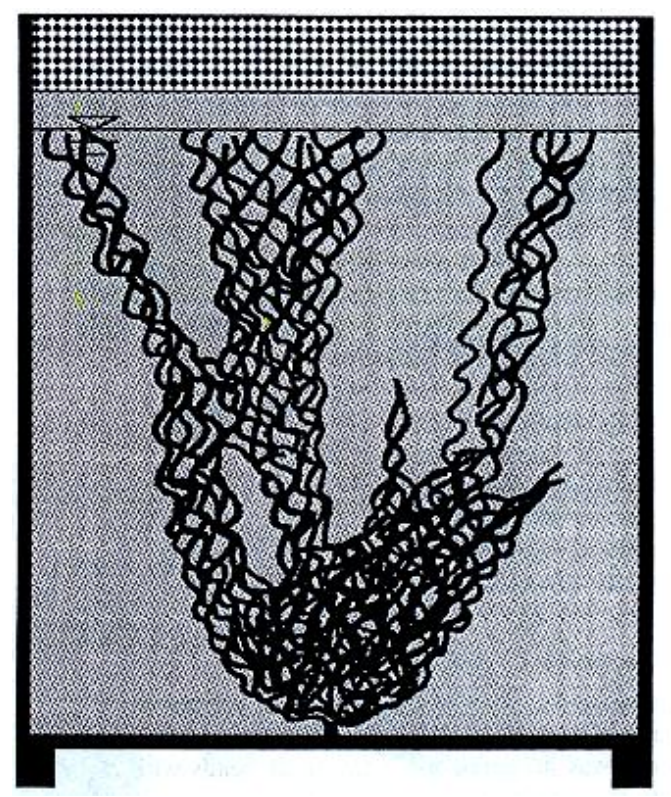

Figura 4.13 - Caminhos de ar sinuosos (Ji et al. (1993))

Alguns resultados de ensaios de laboratório em tanques bidimensionais podem ser vistos na Tabela 4.2, onde são apontados dados relativos ao tamanho do grão, material utilizado, vazão e pressão de injeção, bem como a geometria e característica do fluxo obtido. A Areia Osasco e a Areia do IPT apresentadas na tabela foram o material usado neste trabalho. 
Capítulo 4 - Padrão do Fluxo de Ar em Modelos Físicos

Tabela 4.2 - Resultados de ensaios de laboratório (modificado de Peterson et al. (2001))

\begin{tabular}{|c|c|c|c|c|c|c|}
\hline Referência & $\begin{array}{l}\text { Tamanho dos } \\
\text { grãos (mm) }\end{array}$ & Material & $\begin{array}{l}\text { Vazão } \\
\text { (L/min) }\end{array}$ & $\begin{array}{l}\text { Pressão } \\
(\mathrm{kPa})\end{array}$ & Geometria & Características \\
\hline Elder e Benson (1999) & $\begin{array}{l}2^{b} \\
0,6^{b} \\
0,2^{b}\end{array}$ & $\begin{array}{l}\text { Bolinhas de vidro } \\
\text { Bolinhas de vidro } \\
\text { Bolinhas de vidro }\end{array}$ & $\begin{array}{l}0,35-11,1 \\
4,4 \\
12,0-17,1\end{array}$ & $\begin{array}{l}4,1-11,0 \\
4,8 \\
10,3-17,2\end{array}$ & $\begin{array}{l}\text { Canais do poro tortuosos, slugs descontínuos } \\
\text { e contínuos } \\
\text { Canais do poro retos, slugs descontínuos e } \\
\text { contínuos }\end{array}$ & $\begin{array}{l}\text { Fluxo por canais } \\
\text { Fluxo por canais } \\
\text { Canais muito espaçados }\end{array}$ \\
\hline Brooks; Wise e & 3 & Bolinhas de vidro & $0,023-2,1$ & $6,6-12,9$ & \multirow{11}{*}{ Fluxo difuso } & Fluxo Em Bolhas \\
\hline \multirow[t]{10}{*}{ Annable (1999) } & 2 & Bolinhas de vidro & $0,020-0,90$ & $6,2-7,2$ & & Slugs \\
\hline & 2 & Bolinhas de vidro & $0,175-0,45$ & $7,8-8,6$ & & Mistura de bolhas ou slugs e canais \\
\hline & 2 & Bolinhas de vidro & $1,15-1,625$ & $10,2-12,1$ & & Fluxo por canais \\
\hline & 1,5 & Bolinhas de vidro & 0,020 & 6,8 & & Slugs \\
\hline & 1,5 & Bolinhas de vidro & 0,080 & 7,2 & & Mistura de bolhas ou slugs e canais \\
\hline & 1,5 & Bolinhas de vidro & $0,30-2,05$ & $8,4-12,1$ & & Fluxo por canais \\
\hline & 1,0 & Bolinhas de vidro & 0,020 & 6,4 & & Slugs \\
\hline & 1,0 & Bolinhas de vidro & $0,070-1,825$ & $7,2-12,7$ & & Fluxo por canais \\
\hline & $0,71-0,80$ & Bolinhas de vidro & $0,02-1,93$ & $6,6-13$ & & Fluxo por canais \\
\hline & $0,42-0,50$ & Bolinhas de vidro & & & & Fluxo por canais \\
\hline \multirow[t]{4}{*}{ Ji et al. (1993) } & & & & & \multicolumn{2}{|l|}{ Cone parabólico e perto do poço de injeção } \\
\hline & 4 & Bolinhas de vidro & $0,6-10$ & $1,6-22,4$ & simétrico & Fluxo Em Bolhas \\
\hline & 2 & Bolinhas de vidro & 3 & 4 & Pluma parabólica e densa & Fluxo Em Bolhas e fluxo por canais \\
\hline & 0,75 & Bolinhas de vidro & $0,6-10$ & $4,7-27,1$ & Alguns canais estreitos & Fluxo por canais \\
\hline Peterson, DeBoer e & $0,841-1,00$ & Solo & $1,0-1,3$ & $8,3-8,9$ & \multirow{2}{*}{ Caminhos de ar sinuosos (ver Figura 4.13) } & Canais Discretos \\
\hline Lake. (2000) & $1,00-1,19$ & Solo & $1,0-1,3$ & $8,3-8,9$ & & \\
\hline Areia Osasco* & $0,48^{\mathrm{b}}$ & Solo & $60-72$ & 13 & Caminhos de ar sinuosos & Fluxo por canais \\
\hline Areia do IPT* & $0,43^{b}$ & Solo & & 16 & Parábola simétrica & Fluxo por canais \\
\hline
\end{tabular}

* Ver capítulos 5 e 6. 
Capítulo 4 - Padrão do Fluxo de Ar em Modelos Físicos

\section{Continuação da Tabela 4.2}

\begin{tabular}{|c|c|c|c|c|c|c|}
\hline Referência & $\begin{array}{l}\text { Tamanho dos } \\
\text { grãos (mm) }\end{array}$ & Material & $\begin{array}{l}\text { Vazão } \\
\text { (L/min) }\end{array}$ & $\begin{array}{l}\text { Pressão } \\
(\mathrm{kPa})\end{array}$ & Geometria & Características \\
\hline \multirow{3}{*}{ Reddy e Adams (2001) } & $4,5^{\mathrm{b}}$ & Solo & 2,5 & 4,5 & \multirow{3}{*}{$\begin{array}{l}\text { Pequena parábola } \\
\text { Parábola saindo do ponto de } \\
\text { injeção } \\
\text { Grande parábola }\end{array}$} & Bolhas \\
\hline & $0,52^{b}$ & Solo & 2,5 & 4,5 & & Canais do poro \\
\hline & $0,66^{b}$ & Solo & 2,5 & 4,5 & & Canais do poro \\
\hline \multicolumn{7}{|l|}{ Peterson; Lepczyk e Lake } \\
\hline \multirow[t]{5}{*}{ (1999) } & $1,1^{\mathrm{a}}$ & Solo & $0,2-1,1$ & $4,8-8,9$ & \multirow{2}{*}{ Caminhos de ar sinuosos } & \multirow{2}{*}{ Canais Discretos } \\
\hline & $1,3^{\mathrm{a}}$ & Solo & $0,2-1,1$ & $4,8-8,9$ & & \\
\hline & $1,84^{\mathrm{a}}$ & Solo & $0,2-1,1$ & $4,8-8,9$ & \multirow{3}{*}{$\begin{array}{l}\text { Cone simétrico perto do ponto de } \\
\text { injeção }\end{array}$} & \multirow{3}{*}{ Fluxo de bolhas difuso } \\
\hline & $2,61^{\mathrm{a}}$ & Solo & $0,2-1,1$ & $4,8-8,9$ & & \\
\hline & $4,38^{\mathrm{a}}$ & Solo & $0,2-1,1$ & $4,8-8,9$ & & \\
\hline Peterson et al. (2001) & $0,18-0,212$ & Solo & $0,33-2,3$ & $7,3-10,4$ & Fluxo em Câmara & Fluxo Difuso \\
\hline Chao; Ong e Huang & $0,42-2,38$ & Solo & $1-2$ & - & Cone simétrico & Fluxo em bolhas \\
\hline (2008) & $0,106-1,0$ & Solo & $1-2$ & - & $\begin{array}{l}\text { Diferentes tamanhos de canais, } \\
\text { pluma cilíndrica }\end{array}$ & Fluxo por canais \\
\hline Wehrle (1999) apud & $3^{c}$ & Solo & - & - & Área limitada em torno do ponto & Fluxo discreto, bolhas de ar não contínuas \\
\hline Peterson et al. (2001) & $0,8^{\mathrm{c}}$ & Solo & - & - & de injeção & \\
\hline Adams e Reddy (1997) & $2,5^{\mathrm{c}}$ & Solo & 2,23 & 6,9 & Fluxo uniforme & Fluxo em bolhas \\
\hline apud Peterson et al. & $0,43^{\mathrm{c}}$ & Solo & 2,23 & 6,9 & Rede de canais vasta & Fluxo por canais \\
\hline \multirow[t]{3}{*}{ (2001) } & $0,20^{\mathrm{c}}$ & Solo & 2,23 & 6,9 & & Fluxo por canais \\
\hline & $0,18^{\mathrm{C}}$ & Solo & 2,23 & 6,9 & & Fluxo por canais \\
\hline & $0,08^{\mathrm{c}}$ & Solo & 2,23 & 6,9 & Apenas 1 ou 2 canais & Fluxo por canais \\
\hline
\end{tabular}




\subsection{Injeção de ar}

A injeção de ar realizada em laboratório nos tanques pode ser feita de duas maneiras, por poços de injeção, ou seja, tubos de PVC cravados no solo ou por um difusor localizado na base do tanque. Na Figura 4.14 podem ser vistos exemplos de injeção em poço (a) e com difusor (b).
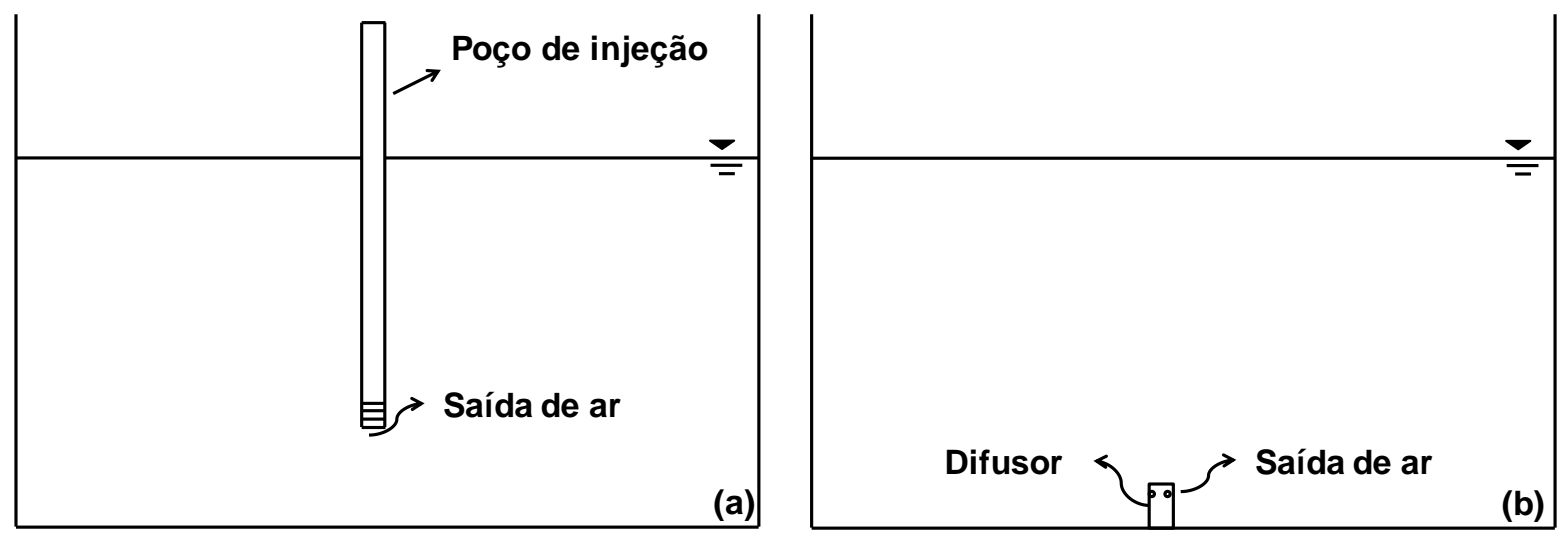

Figura 4.14 - Desenho esquemático do poço de injeção com pedra porosa na ponta para a distribuição do ar em (a) e tanque com injeção de ar através de difusor em (b)

Baker e Benson (2007) usaram para a injeção de ar no tanque bidimensional um poço de injeção que foi fabricado usando um tubo de PVC rígido com $13 \mathrm{~mm}$ de diâmetro. Na ponta do tubo foi colocada uma pedra porosa para que $o$ ar fosse mais bem distribuído na saída do tubo para o solo. A pedra porosa foi fabricada usando bolinhas de vidro e cola epoxy na proporção de (36:1 em massa). As dimensões do tanque eram 1,1 $\mathrm{m}$ de largura, $0,9 \mathrm{~m}$ de altura e $30 \mathrm{~mm}$ de espessura.

Elder e Benson (1999) em seus ensaios usaram um tubo de aço inoxidável para a injeção de ar, o diâmetro do tubo de injeção era de 6,4 mm sendo as dimensões do tanque de $40 \mathrm{~cm}$ de largura e altura e $38 \mathrm{~mm}$ de espessura.

O uso de difusor em ensaios de laboratório é mais comum devido à fácil instalação e operação se comparado com a cravação de poços em tanques bidimensionais.

Chao; Ong e Huang (2008) usaram um difusor para a injeção de ar, o difusor tem diâmetro de $1,5 \mathrm{~cm}$ e fica localizado no centro da base do tanque, tendo o tanque as dimensões de $50 \mathrm{~cm}$ de altura, $50 \mathrm{~cm}$ de largura e $3 \mathrm{~cm}$ de espessura. Elder e 
Benson (1999), Ji et al. (1993), Peterson; Lepczyk e Lake (1999), Peterson et al. (2001) e Reddy e Adams (2001) também usaram difusores em seus estudos. Dentre estes autores o único que apresentou detalhes do difusor foi Peterson et al. (2001) que usaram um difusor com $2 \mathrm{~cm}$ de diâmetro e com altura de $7 \mathrm{~cm}$ localizado no fundo do tanque. Esse difusor possui seis furos de 1,5 $\mathrm{mm}$ de diâmetro distribuídos simetricamente pelo difusor e situados a $1,9 \mathrm{~cm}$ do topo.

$\mathrm{Na}$ Tabela 4.3 podem ser observadas algumas das características dos tanques bidimensionais utilizados por diferentes autores em seus estudos de laboratório e

Tabela 4.3 - Características dos tanques bidimensionais e o tipo de injeção utilizado.

\begin{tabular}{|c|c|c|c|c|}
\hline Referência & $\begin{array}{c}\text { Dimensões }^{\top} \\
(\mathrm{cm})\end{array}$ & $\begin{array}{l}\text { Tipo de } \\
\text { Injeção }\end{array}$ & $\begin{array}{c}\text { Dimensões de } \\
\text { injeção }\end{array}$ & Material \\
\hline $\begin{array}{l}\text { Baker e Benson } \\
(2007)\end{array}$ & $110 \times 90 \times 3$ & Poço vertical & $\begin{array}{l}\text { Tubo de PVC } 13 \\
\text { mm de diâmetro }\end{array}$ & Placas de vidros \\
\hline $\begin{array}{l}\text { Chao; Ong e Huang } \\
(2008)\end{array}$ & $50 \times 50 \times 3$ & Difusor & $\begin{array}{l}\text { Diâmetro de } 1,5 \\
\mathrm{~cm}\end{array}$ & $\begin{array}{l}\text { Plexiglas com } \\
\text { espessura de } 5 \mathrm{~mm}\end{array}$ \\
\hline Ji et al. (1993) & $73 \times 88 \times 2,54$ & Difusor & $\begin{array}{l}\text { Diâmetro de } 1,27 \\
\mathrm{~cm} \mathrm{e} 2,54 \mathrm{~cm} \text { de } \\
\text { altura }\end{array}$ & $\begin{array}{ll}\text { Plexiglas } & \text { com } \\
\text { espessura de } & 1,27 \\
\mathrm{~cm} & \end{array}$ \\
\hline $\begin{array}{l}\text { Elder e Benson } \\
(1999)\end{array}$ & $40 \times 44 \times 3,8$ & Poço vertical & $\begin{array}{l}\text { Tubo de aço } \\
\text { inoxidável com } \\
6,4 \quad \mathrm{~mm} \text { de } \\
\text { diâmetro }\end{array}$ & $\begin{array}{l}\text { Placas de Acrílico } \\
\text { com } 1,27 \mathrm{~cm} \text { de } \\
\text { espessura }\end{array}$ \\
\hline $\begin{array}{l}\text { Peterson et al. } \\
(2001)\end{array}$ & $\begin{array}{l}102 \times 102 \times 5 e \\
127 \times 252 \times 9\end{array}$ & Difusor & $\begin{array}{l}\text { Diâmetro de } 2 \mathrm{~cm} \\
\text { e } 7 \mathrm{~cm} \text { de altura }\end{array}$ & $\begin{array}{l}\text { Placas de Acrílico } \\
\text { com } 1,6 \mathrm{~cm} \text { de } \\
\text { espessura }\end{array}$ \\
\hline $\begin{array}{l}\text { Reddy e Adams } \\
(2001)\end{array}$ & $121 \times 72 \times 10$ & Difusor & - & Plexiglas \\
\hline $\begin{array}{l}\text { Peterson; Lepczyk } \\
\text { e Lake (1999) }\end{array}$ & $90 \times 90 \times 2,5$ & Difusor & $\begin{array}{l}\text { Diâmetro de } 2 \mathrm{~cm} \\
\text { e } 3 \mathrm{~cm} \text { de altura, } \\
\text { com } 6 \text { furos de } \\
1,5 \mathrm{~mm}\end{array}$ & $\begin{array}{l}\text { Placas de acrílico } \\
\text { com } 1,6 \mathrm{~cm} \text { de } \\
\text { espessura }\end{array}$ \\
\hline
\end{tabular}

\footnotetext{
1 (comprimento $\mathrm{x}$ altura $\mathrm{x}$ espessura)
} 


\section{Capítulo 5}

\section{Fundamentos Teóricos do Método}

\subsection{Fluxo de gases no solo - Advecção}

Os contaminantes em fase gasosa presentes no solo serão transportados para longe da pluma de contaminação líquida, através de basicamente dois mecanismos de transporte: advecção e difusão. São esses dois mecanismos que regem o movimento de gases nos poros do solo.

Como a movimentação de gases e vapores na região insaturada dos solos é mais rápida que a de líquidos, a nuvem de contaminação gasosa irá geralmente se adiantar em relação à pluma líquida, podendo conduzir contaminante em concentrações que excedam os limites legais.

$\mathrm{Na}$ advecção o soluto é carregado pela água em movimento, ou ar nesse caso, sem que haja variação da concentração da solução, o gás viaja de uma região de alto gradiente hidrostático para uma de baixo. Já a difusão ocorre devido à variação na concentração de contaminante, o fluxo vai da região de maior concentração para a de menor.

\subsubsection{Lei de Darcy para fluxo de gases}

Em 1856, Henry Darcy, estudando fluxo de água em meios porosos, verificou experimentalmente que a vazão $(Q)$ é diretamente proporcional à área $(A)$ da seção transversal e a diferença de altura d'água $(\Delta h)$ é inversamente proporcional ao comprimento da coluna (L), $\Delta \mathrm{h} / \mathrm{L}$ é o gradiente hidráulico, e $\mathrm{K}$ a condutividade. Como isto tem se a Lei de Darcy:

$$
\frac{Q}{A} \sim \frac{\Delta h}{L}
$$


Sendo que:

$$
h=z+\frac{P}{\gamma_{f}}
$$

z - cota;

$\mathrm{P}$ - pressão;

$Y_{f}-$ peso específico do fluido.

Para um fluxo horizontal tem-se que a cota (z) é constante por este motivo $h=\frac{P}{\gamma_{f}}$.

A permeabilidade intrínseca não depende do fluido percolante sendo função apenas da estrutura dos poros e granulometria do material. A relação entre a permeabilidade intrínseca $(k)$ e a condutividade $(K)$ é dada por:

$$
K=k \frac{\rho_{f} g}{\mu_{f}} \therefore K=k \frac{\gamma_{f}}{\mu_{f}}
$$

$\mu_{\mathrm{f}}-$ viscosidade dinâmica do fluido;

$\rho_{f}-$ densidade do fluido.

Substituindo a equação (5.3) em (5.1):

$$
Q=\frac{k \gamma_{f}}{\mu_{f}} \frac{\Delta h}{L} A
$$

A pressão total pode ser definida como sendo $P_{t}=\gamma_{f} h$.

$$
\Delta h=h_{1}-h_{2}
$$

Multiplicando ambos os lados da equação (5.5) pelo peso específico do fluido $\left(\mathrm{y}_{\mathrm{f}}\right)$ tem-se:

$$
\begin{gathered}
\gamma_{f} \Delta h=\gamma_{f} h_{1}-\gamma_{f} h_{2} \\
\gamma_{f} \Delta h=P_{t 1}-P_{t 2}=\Delta P_{t}
\end{gathered}
$$


Substituindo a equação (5.7) na (5.4):

$$
\begin{gathered}
Q=\frac{k}{\mu_{f}} \frac{\Delta P_{t}}{L} A \\
Q=\frac{k}{\mu_{f}} \frac{\left(P_{t 1}-P_{t 2}\right)}{L} A
\end{gathered}
$$

$\mathrm{Na}$ equação (5.9) pode-se notar que para um mesmo solo com a mesma variação de pressão o que irá influenciar a vazão é a viscosidade dinâmica do fluido utilizado. Quanto maior a viscosidade do fluido menor a vazão; é por este motivo que em um ensaio com água e outro com ar a vazão encontrada é maior para o ensaio com ar, pois sua viscosidade é da ordem de $10^{-5}$ Pa.s enquanto que a da água é da ordem de $10^{-3}$ Pa.s.

No caso de fluxo vertical é preciso considerar a parcela referente à cota $(z)$ da equação (5.2), portanto a equação (5.7) ficaria:

$$
\begin{aligned}
& \Delta h=z_{1}+\frac{P_{1}}{\gamma_{f}}-\left(z_{2}+\frac{P_{2}}{\gamma_{f}}\right) \\
& \Delta h=z_{1}-z_{2}+\left(\frac{P_{1}-P_{2}}{\gamma_{f}}\right)
\end{aligned}
$$

Considerando $z_{1}$ a cota de entrada e $z_{2}$ a cota de saída de um corpo de prova com altura $L$ tem-se que:

$$
L=z_{2}-z_{1}
$$

Substituindo a equação (5.11) e (5.12) na equação (5.4), se obtém:

$$
\begin{aligned}
& Q=\frac{k \gamma_{f}}{\mu_{f} L} A\left[\left(\frac{P_{1}-P_{2}}{\gamma_{f}}\right)-L\right] \\
& Q=\frac{k}{\mu_{f}} A\left[\left(\frac{P_{1}-P_{2}}{L}\right)-\gamma_{f}\right]
\end{aligned}
$$


Para fluxo em gases o último termo da equação (5.14) pode ser desprezado se comparado com a componente da pressão; com isso a equação para fluxo de gases vertical se torna igual à equação para fluxo de gases horizontal.

Em se tratando de um fluido compressível como o gás, considerando a Lei dos Gases Ideais $\left(P=\rho_{f} R T\right)$ e levando em conta que a massa que entra no corpo de prova deve ser a mesma que sai, ou seja, o fluxo de massa é constante, tem-se que $\mathrm{Pq}=$ constante. Onde $\mathrm{R}$ é a constante do gás, $\mathrm{T}$ é a temperatura em Kelvin, $\rho_{\mathrm{f}}$ é a densidade do fluido e q é a velocidade aparente do fluido.

$$
P V=n R T=\frac{m}{P_{m}} R T
$$

$\mathrm{P}_{\mathrm{m}}$ - peso molecular

$$
\begin{gathered}
\frac{P_{m}}{R T}=\text { Constante } \\
\rho=\frac{m}{V} \therefore V=\frac{m}{\rho} \\
P \frac{m}{\rho}=\frac{m}{P_{m}} R T \therefore \rho=\frac{P_{m}}{R T} P \\
\rho=C P
\end{gathered}
$$

Introduzindo a velocidade aparente do fluido (q) na equação (5.9) e considerando derivadas ao invés de diferenças finitas, se obtém que:

$$
q=-\frac{k}{\mu_{f}} \frac{d P}{d x}
$$

Multiplicando-se a equação (5.20) por P em ambos os lados tem-se:

$$
P q=\frac{k}{\mu_{f}} P \frac{d P}{d x}
$$


Capítulo 5 - Fundamentos Teóricos do Método

Sendo P função de $\mathrm{x}$ :

$$
\begin{aligned}
& \frac{d P^{2}}{d x}=2 P \frac{d P}{d x} \\
& P \frac{d P}{d x}=\frac{1}{2} \frac{d P^{2}}{d x}
\end{aligned}
$$

Substituindo a equação (5.23) em (5.21):

$$
P q=\frac{k}{\mu_{f}} \frac{1}{2} \frac{d P^{2}}{d x}
$$

Integrando a equação (5.24) de 0 a L (ver Figura 5.1) tem-se que:

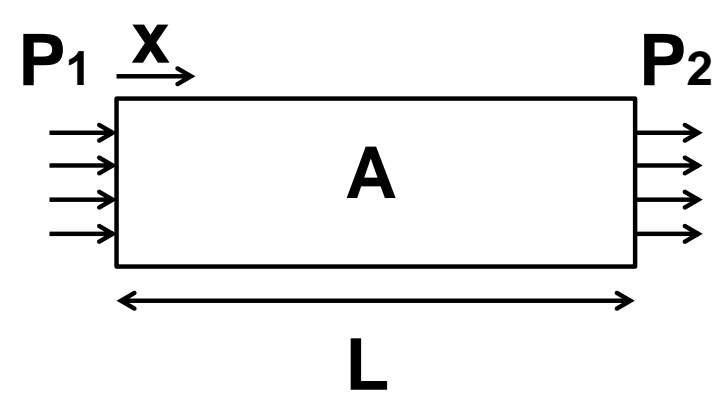

Figura 5.1 - Esquema de fluxo por uma seção de área A e comprimento L.

$$
P q L=\frac{k}{\mu_{f}} \frac{1}{2}\left(P_{1}^{2}-P_{2}^{2}\right)
$$

Supondo que $\mathrm{P}=\mathrm{P}_{2}$ que é a pressão de saída e substituindo a velocidade aparente do fluido pela vazão na saída $Q$, se obtém:

$$
P_{2} \frac{Q}{A} L=\frac{k}{\mu_{f}} \frac{1}{2}\left(P_{1}^{2}-P_{2}^{2}\right)
$$

Isolando k na equação (5.26), tem-se: 


$$
k=\frac{2 Q \mu_{f} L P_{2}}{A\left(P_{1}^{2}-P_{2}^{2}\right)}
$$

A equação (5.27) foi utilizada para o cálculo da Condutividade ao ar das areias utilizadas neste estudo, sendo que a pressão de saída foi considerada como sendo a pressão atmosférica.

\subsection{Pressão capilar}

A franja capilar formada acima do nível d'água é consequência da pressão capilar. Em solos finos a franja capilar é maior justamente devido à pressão capilar ser maior do que em solos grossos.

Ao introduzir-se um tubo capilar em uma superfície livre de um líquido, a interface líquido-gás se tornará côncava isso se o líquido tiver tendência de umedecer o tubo, nesse caso a pressão no líquido internamente ao tubo capilar ficará menor que na superfície livre externa ao tubo e como consequência o líquido subirá no tubo (ascensão capilar) até que o peso da coluna se iguale ao valor da diferença de pressão capilar $\left(p_{c}\right)$. Caso o líquido não molhe o tubo, ocorrerá uma depressão capilar de uma altura que seja suficiente para equilibrar a diferença de pressão. A altura de ascensão ou depressão capilar $h_{c}$ para um tubo capilar é:

$$
h_{c}=\frac{2 \sigma_{g f} \cos \omega}{\gamma_{f} r}
$$

$r$ - raio do tubo;

$\omega$ - ângulo de contato entre os fluidos;

$\mathrm{Y}_{f}-$ peso específico do fluido.

A diferença de pressão $p_{c}$ (pressão capilar) é:

$$
p_{c}=\frac{2 \sigma_{g f} \cos \omega}{r}
$$


Quando dois fluidos imiscíveis estão em contato no interior do poro, existe uma descontinuidade na pressão através da interface. Essa diferença de pressão é dada pela pressão capilar, ou seja, pressão capilar é a diferença de pressão entre dois fluidos; a tensão superficial existente na interface desses dois fluidos é que causa dessa diferença.

$$
p_{c=} p_{a}-p_{h}
$$

$p_{\mathrm{a}}$ - pressão do ar,

$p_{h}-$ pressão da água.

A pressão de entrada de ar é o valor da pressão capilar na qual o fluxo de ar começa. $\mathrm{O}$ ar migra pelos poros do solo quando a pressão de ar é maior do que a soma da pressão de água com a pressão capilar (ver equação 2.3). O valor da pressão de entrada de ar é obtido através da curva de retenção de água.

A pressão de entrada de ar depende do tamanho e da acomodação dos grãos e outras propriedades do solo. As areias finas possuem pressões capilares maiores que as areias grossas. O fluxo do ar pelos poros do solo prefere entrar nos poros onde a pressão capilar é menor, esse é um dos motivos que esse método de injeção de ar é mais eficiente para areias grossas. Na Tabela 5.1 podem ser vistos alguns valores aproximados de pressão de entrada de ar para diferentes tipos de solos.

Tabela 5.1 - Valores de Pressão de entrada de ar (valores obtidos de USACE (2008))

\begin{tabular}{lcc}
\hline \multicolumn{1}{c}{ Solo } & Diâmetro do poro mais largo $(\mu \mathrm{m})$ & $\Psi_{\mathrm{b}}(\mathrm{kPa})$ \\
\hline Areia grossa, macro poros & $>1000$ & $<0,3$ \\
Areia fina a média & 100 & 3,0 \\
Silte & 10 & 30 \\
Argila siltosa & $<1$ & $>300$ \\
\hline
\end{tabular}

Considerando uma bolha dentro de um poro do solo e assumindo que o tamanho da bolha é da mesma ordem que o poro, a bolha tenderá a subir devido à associação da força de empuxo, e a pressão capilar associada com o estreitamento do poro 
acima da bolha que opõe o movimento para cima. Se a força de empuxo for suficiente para vencer a pressão capilar do estreitamento do poro, então a bolha irá subir; mas se a força de empuxo não for suficiente para superar a pressão capilar, então a bolha ficará presa no poro. Uma pressão adicional terá que ser fornecida pela fase de ar a fim de fazer a bolha subir pelo estreitamento do poro. Esta pressão adicional pode ser fornecida por uma conexão de ar através da injeção (um canal de ar, por exemplo). Isto define o cenário de divisão entre o fluxo por bolhas e o fluxo por canais de ar. O fluxo por bolha ira ocorrer no solo quando a força de empuxo é grande o suficiente para ultrapassar a pressão capilar, e o fluxo por canais irá ocorrer quando a pressão capilar é tal que impede o avanço da bolha. Isso quer dizer que a mudança no tipo de fluxo ocorre quando a força capilar e a de empuxo invertem seus domínios.

\subsection{Transporte e transferência de massa}

O transporte de massa durante a injeção de ar requer conhecimento do tamanho, da forma e a área interfacial dos canais de ar. O diâmetro dos canais de ar é muito pequeno; aproximadamente do tamanho do poro entre um grão e outro; a área de contato de ar e água com os canais é extremamente pequena, resultando em uma transferência de massa lenta.

A eficiência do método de injeção de ar depende do volume do aqüífero que é alcançado pelos canais de ar e a soma de transferência de massa entre a fase gasosa e a fase aquosa. A transferência de massa na injeção de ar consiste primeiramente na difusão dos contaminantes aquosos e depois ocorre a volatilização dos contaminantes pelos canais.

Como a transferência de massa é limitada pela difusão, e a remediação da zona saturada é primeiramente devido à formação dos canais de ar, a maior parte dos benefícios da remediação ocorrem na franja capilar e na zona não saturada.

Quando apenas alguns canais de ar estão presentes no solo, menos água está em contato com o ar injetado e a transferência de massa entre a água e o ar pode ser limitada pela capacidade do contaminante de migrar para os canais de ar. A 
transferência de massa durante a injeção só ocorre próximo aos canais de ar. $\mathrm{Na}$ Figura 5.2 pode ser visto como os canais de ar afetam a eficiência do método e a transferência de massa. Para que a injeção de ar seja eficiente é necessária uma alta saturação de ar e de um grande número de canais pequenos como na Figura 5.2-(c) onde a transferência de massa é moderada. Já na Figura 5.2-(a) a saturação de ar é baixa os canais são pequenos e a transferência de massa é muito baixa, e na Figura 5.2-(b) a saturação de ar é alta, os canais são grandes e a transferência de massa também é muito baixa.
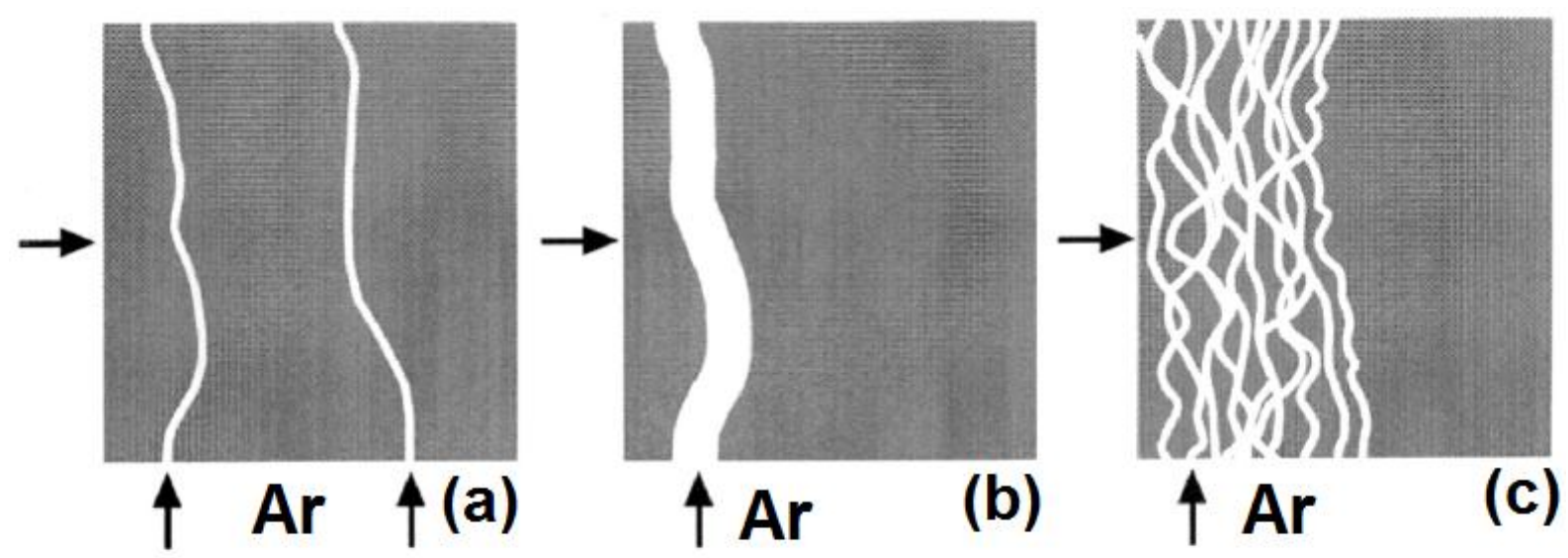

\section{$\rightarrow$ Indica a direção do fluxo da água subterrânea}

Figura 5.2 - Canais de ar com vários tamanhos e saturações de ar (adaptado de USACE (2008))

Vários autores consideram que a difusão é o que limita o processo, já Johnston et al. (1998) concluíram que a evaporação da água dentro dos canais de ar pode resultar em uma significante advecção dos contaminantes dissolvidos pelos canais de ar.

O fluxo de massa é definido como a variação de massa por unidade de área da seção transversal ao fluxo por unidade de tempo:

$$
J=\frac{\Delta m}{A \Delta t}
$$

Segundo Marley, Hazebrouck e Walsh (1992) teoricamente um grande número de bolhas pequenas irá induzir uma melhor transferência de massa dos VOCs da fase 
Capítulo 5 - Fundamentos Teóricos do Método

aquosa em comparação a um número pequeno de bolhas grandes ou fluxo por canais.

A distribuição dos canais, seguido pela limitação da transferência de massa dos Compostos Orgânicos Voláteis (VOC's), dominam a eficiência do método. As limitações dos mecanismos de transporte estão relacionadas com o tipo de contaminante, densidade dos canais de ar e da permeabilidade do solo. 


\section{Capítulo 6}

\section{Ensaios de Laboratório e Resultados}

Para a realização do presente trabalho foram utilizados três solos distintos, um deles uma areia natural denominada de Areia Osasco, outro uma areia comercial e homogênea denominada de Areia do IPT e por último um solo residual de gnaisse (silte) utilizado nas lentes de baixa permeabilidade. Os ensaios foram realizados no Laboratório de Mecânica dos Solos (LMS) da Escola Politécnica da Universidade de São Paulo.

\subsection{Ensaios Realizados}

Para as areias foram realizados ensaios de granulometria, densidade dos grãos, índice de vazios máximo e mínimo, curva de retenção e permeabilidade à água e ao ar.

Os ensaios com o solo utilizado nas lentes de baixa permeabilidade (solo residual) não foram executados para este trabalho, pois este solo já foi utilizado anteriormente por Oliveira, 2004. Também não foram feitos alguns dos ensaios com a Areia Osasco (índice de vazios máximo e mínimo e densidade seca dos grãos), pois essa mesma areia já foi utilizada anteriormente; a descrição e os resultados completos dos ensaios podem ser encontrados em Teixeira, 2008.

A curva de retenção da Areia Osasco foi realizada novamente devido a sua importância e também o ensaio de granulometria devido à exposição da areia a chuva, o que pode ter ocasionado a perda de finos.

\subsubsection{Curva de retenção de água ou curva característica}

A curva de retenção de água ou curva característica descreve, em termos gerais, a relação entre a sucção do solo e o teor de umidade volumétrica ou grau de 
saturação do solo. A capacidade de retenção do solo é influenciada por diversos fatores, tais como: a distribuição granulométrica e sua estrutura, ou seja, a distribuição dos poros e sua composição mineralógica. A curva de retenção é uma ferramenta muito importante, no estudo de fluxo em solos não saturados, para o entendimento da interação ar-água no solo e também é utilizada na determinação da dinâmica da entrada de ar no solo.

Para a obtenção da curva de retenção podem ser utilizados dois processos, o de umedecimento ou o de secagem; na Figura 6.1 pode ser visto um modelo dessas curvas para um solo de granulometria grossa (areia). Percebe-se que para uma mesma sucção $\left(\psi_{1}\right)$ tem-se dois valores distintos de teor de umidade volumétrica $(\theta)$, um correspondente a curva de retenção por umedecimento $\left(\theta_{1 \mathrm{w}}\right)$ e outro para a de secagem $\left(\theta_{1 \mathrm{~d}}\right)$, sendo que $\theta_{1 \mathrm{~d}}>\theta_{1 \mathrm{w}}$. Isto acontece porque geralmente mais água é retida no solo durante o processo de secagem do que é adsorvida, com a mesma sucção, durante o processo de umedecimento. Foram realizados apenas ensaios com a técnica de secagem dos corpos-de-prova para a obtenção da curva de retenção de água.

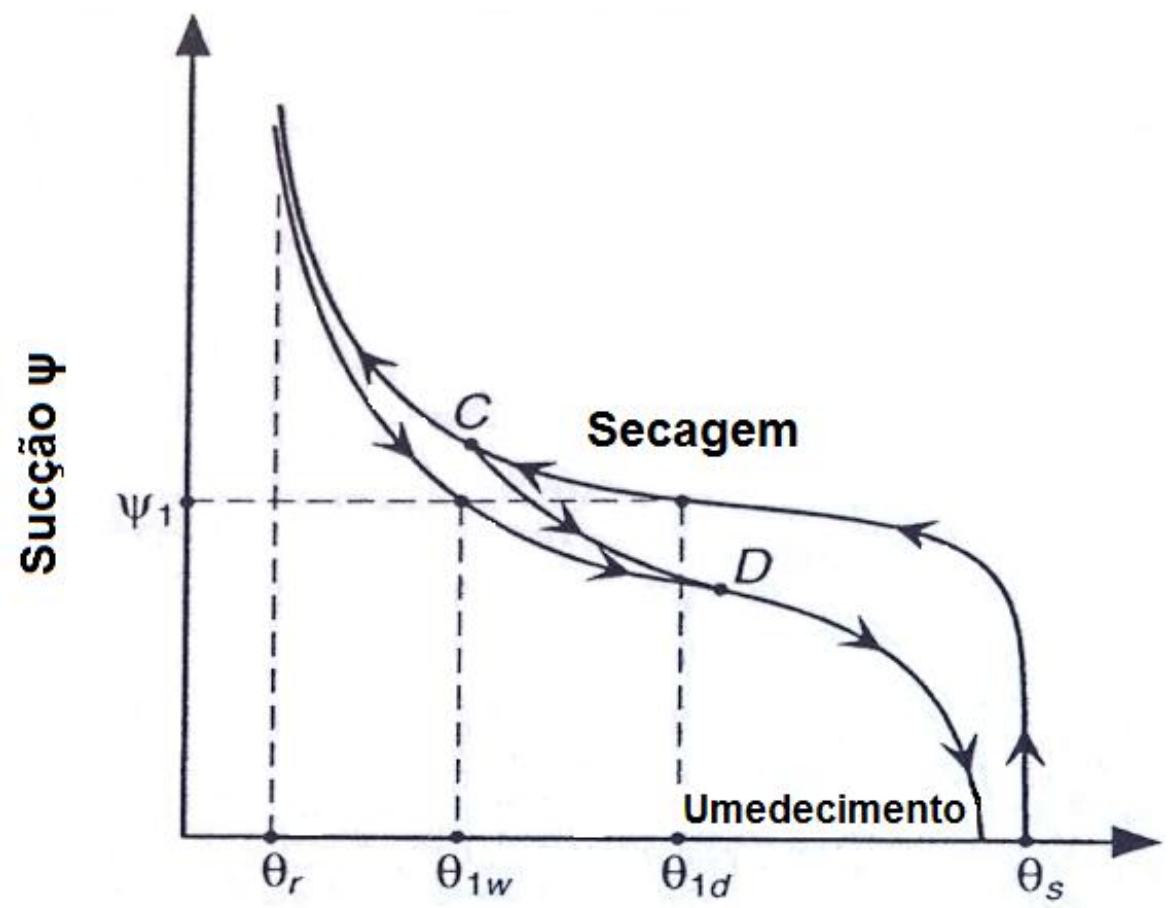

Teor de umidade volumétrica, $\theta$

Figura 6.1 - Desenho conceitual do efeito da histerese na curva de retenção (adaptada de LU e LIKOS, 2004). 
Na Figura 6.1 também pode ser visto que durante o processo de umedecimento, o teor de umidade volumétrica equivalente à saturação completa $\left(\theta_{\mathrm{s}}\right)$ não é atingida devido a bolhas de ar que ficam presas nos poros do solo; e que a histerese é menor perto do teor de umidade volumétrica residual $\left(\theta_{\mathrm{r}}\right)$.

\subsubsection{Procedimento do ensaio}

No presente estudo foi utilizada a placa de sucção, para a determinação da curva de retenção, que aplica a pressão negativa através da diferença de altura entre um reservatório de água e a pedra porosa onde são colocadas as amostras. A água fica com sucção correspondente à diferença de altura entre a amostra e o topo do reservatório. A placa de sucção atinge uma altura de $3 \mathrm{~m}$, por isso o ensaio foi realizado até a sucção de $30 \mathrm{kPa}$. Na Figura 6.2-(a) está representada a placa de sucção e o reservatório de água.

Para a realização do ensaio é preciso que a pedra porosa esteja saturada. Para a moldagem dos corpos de prova utilizou-se areia seca ao ar; que foi compactada dentro de cilindros de PVC com volume conhecido e com auxílio de um soquete de madeira, ver Figura 6.2-(b). A Compacidade Relativa das areia foi de 0,7 , sendo que o índice de vazios (e) da Areia Osasco foi de aproximadamente 0,65 e da Areia do IPT de 0,86. As amostras foram compactadas diretamente na placa de sucção. Após esta etapa os corpos de prova foram saturados por capilaridade, para garantir a saturação máxima, foi imposta uma sucção de $0 \mathrm{kPa}$ as amostras. Após o término da montagem do ensaio as amostras são protegidas por uma cobertura plástica para manter a saturação imposta pela sucção, sem que haja evaporação; observar Figura 6.2-(c).

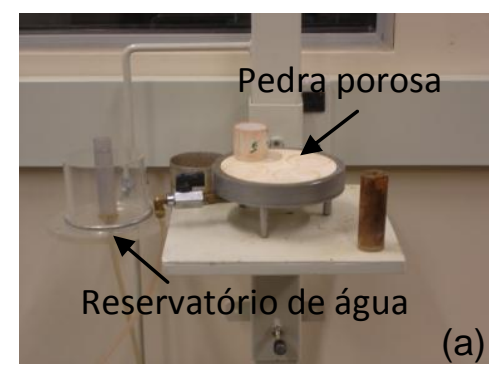

Figura 6.2 - Placa de sucção durante o processo de montagem do ensaio.
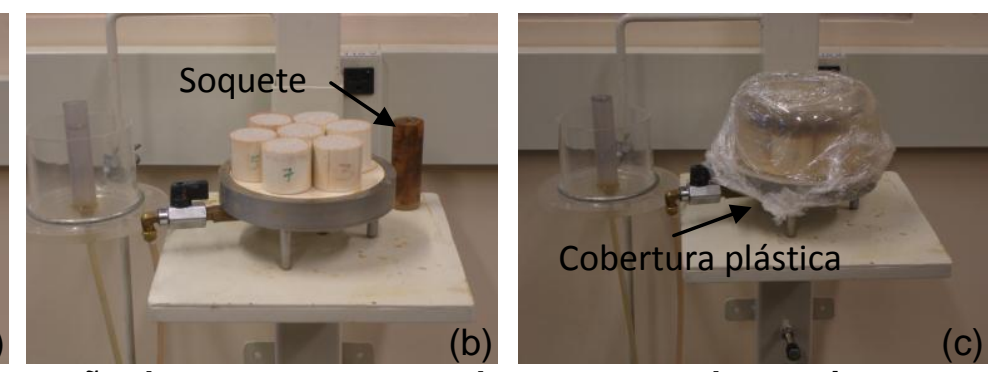


\subsubsection{Modelo proposto por Brooks e Corey (1964)}

Podem ser retirados da curva de retenção alguns dos parâmetros a serem utilizados para análise numérica de fluxo de gases. Esses parâmetros são a pressão de entrada de $\operatorname{ar}\left(\psi_{\mathrm{b}}\right)$, a saturação residual $\left(\mathrm{S}_{\mathrm{r}}\right)$ e a inclinação da reta que corresponde ao valor do índice de distribuição dos poros do solo $(\lambda)$. A pressão de entrada de ar representa a diferença de pressões entre água e ar necessário para causar a drenagem do maior poro do solo, ou seja, é quando a amostra começa a dessaturar descrevendo assim a sucção na qual o ar começa a entrar nos poros mais largos do solo. A saturação residual está associada ao estágio residual da dessaturação do solo, neste estágio para retirar a água que ainda resta no solo é necessária a aplicação de uma grande sucção. O parâmetro de distribuição dos poros $(\lambda)$ caracteriza a faixa de tamanho dos poros de um solo, sendo que altos valores de $\lambda$ correspondem a solos que possuem pouca variação no tamanho dos poros, ou seja, possuem uma distribuição de poros uniforme; e também possuem curvas de retenção onde a drenagem ocorre rapidamente com uma pequena alteração na sucção, como exemplo disto tem-se a areia.

O teor de umidade volumétrico adimensional pode ser definido como:

$$
\Theta=\frac{\theta-\theta_{r}}{\theta_{s}-\theta_{r}}
$$

$\Theta$ - teor de umidade volumétrico adimensional;

$\theta_{\mathrm{r}}-$ teor de umidade volumétrico residual;

$\theta_{s}-$ teor de umidade volumétrico equivalente a saturação completa.

Se o teor de umidade volumétrico residual $\left(\theta_{r}\right)$ for igual a zero então o teor de umidade volumétrico $(\theta)$ é igual à saturação de água $(S)$.

A saturação completa $\left(S_{c}\right)$ corresponde ao ponto onde todos os poros do solo estão preenchidos com água. $\mathrm{O}$ grau de saturação efetivo é também normalizado para a condição de completa saturação $\left(S_{c}=1\right)$, através da seguinte equação: 


$$
\mathrm{S}_{\mathrm{e}}=\frac{S-S_{r}}{1-S_{r}} \therefore \Theta=S_{e}
$$

Se a saturação residual $\left(S_{r}\right)$ for igual a zero então o grau de saturação efetiva $\left(S_{e}\right)$ é igual ao grau de saturação da água (S).

Brooks e Corey (1964) relacionam a saturação efetiva com a sucção através da seguinte fórmula:

$$
\theta=S_{e}=\left\{\begin{array}{cc}
1 & \text { se } \psi<\psi_{\mathrm{b}} \\
\frac{\left(\Psi_{\mathrm{b}}\right)^{\lambda}}{\psi} & \text { se } \psi \geq \psi_{\mathrm{b}}
\end{array}\right.
$$

Que pode ser apresentada da seguinte forma:

$$
\theta=\left\{\begin{array}{cc}
\theta_{s} & \text { se } \psi<\psi_{\mathrm{b}} \\
\theta_{r}+\left(\theta_{s}-\theta_{r}\right) \frac{\left(\psi_{\mathrm{b}}\right)^{\lambda}}{\psi} & \text { se } \psi \geq \psi_{\mathrm{b}}
\end{array}\right.
$$

$\theta$ - teor de umidade volumétrico;

$\mathrm{S}_{\mathrm{e}}$ - saturação efetiva;

$\psi$ - sucção;

$\psi_{\mathrm{b}}$ - pressão de entrada de ar;

$\lambda$ - índice de distribuição dos poros.

O modelo de Brooks e Corey (1964) é mais adequado para solos grossos (areias) onde a drenagem ocorre rapidamente em uma estreita faixa de sucção; pois o modelo tende a perder a eficiência se aplicado para altos valores de sucção aproximando-se da saturação residual.

\subsubsection{Modelo proposto por Van Genuchten (1980)}

Segundo Van Genuchten o teor de umidade volumétrico adimensional pode ser definido como: 


$$
\begin{gathered}
\Theta=S_{e}=\left[\frac{1}{1+(\alpha \psi)^{n}}\right]^{m} \\
\alpha=\frac{1}{\psi_{b}}
\end{gathered}
$$

Onde $\alpha, n$, e $m$ são os parâmetros de ajuste do modelo; sendo que $\alpha$ é o inverso da pressão de entrada de ar medido em $\mathrm{kPa}^{-1}$, $\mathrm{n}$ está relacionando com a distribuição dos poros e $m$ com a simetria global da curva de retenção. O parâmetro $m$ se relacionada com o parâmetro $n$ das seguintes formas:

$$
m=1-\frac{1}{n}
$$

ou

$$
m=1-\frac{1}{2 n}
$$

As equações (6.7) e (6.8) reduzem a flexibilidade do modelo de Van Genuchten, mas facilitam a sua aplicação. Baixos valores de a representam solos com altas pressões de entrada de ar.

Substituindo o teor de umidade volumétrico adimensional da equação (6.5) pela equação (6.1) tem-se que:

$$
\theta=\theta_{r}+\frac{\left(\theta_{s}-\theta_{r}\right)}{\left[1+(\alpha \psi)^{n}\right]^{m}}
$$

\subsubsection{Permeabilidade ao ar}

A permeabilidade ao ar do solo determina a taxa em que o ar pode ser injetado na zona saturada. E também é um fator significante na determinação da taxa de transferência de massa dos constituintes da fase dissolvida para a fase de vapor.

A permeabilidade ao ar foi calcula através da seguinte expressão, que leva em consideração a compressibilidade do fluido: 


$$
k=\frac{2 Q \mu_{a r} L P_{a t m}}{A\left(P^{2}-P_{a t m}^{2}\right)}
$$

$k=$ permeabilidade intrínseca $\left(\mathrm{m}^{2}\right)$,

$\mathrm{Q}=\operatorname{vazão}\left(\mathrm{m}^{3} / \mathrm{s}\right)$,

$\mu_{\mathrm{ar}}=$ viscosidade dinâmica do ar (Pa.s),

$\mathrm{L}=$ comprimento do corpo de prova $(\mathrm{m})$,

$A$ = área da seção transversal do corpo de prova $\left(\mathrm{m}^{2}\right)$,

$\mathrm{P}=$ pressão absoluta aplicada, pressão de entrada $(\mathrm{kPa})$,

$\mathrm{P}_{\mathrm{atm}}=$ pressão atmosférica, pressão de saída $(\mathrm{kPa})$.

Para se calcular a condutividade ao ar usou-se a seguinte equação:

$$
K_{a r}=k \frac{\rho_{a r} g}{\mu_{a r}}
$$

$K_{a r}=$ condutividade ao ar $(\mathrm{m} / \mathrm{s})$,

$\rho_{a r}=$ densidade do ar (o valor usado foi $1,196 \mathrm{~kg} / \mathrm{m}^{3}$ ),

$g=$ aceleração da gravidade $\left(\mathrm{m} / \mathrm{s}^{2}\right)$,

$\mu_{a r}=$ viscosidade dinâmica do ar (valor usado $\left.1,83 \times 10^{-5} \mathrm{~Pa} . \mathrm{s}\right)$,

A Figura 6.3 apresenta a relação teórica entre a condutividade à água e ao ar. Notase que a condutividade a água é maior do que condutividade ao ar. A permeabilidade intrínseca apresentada na Figura 6.4 pode ser comparada com as condutividades ao ar e à água para vários tipos de solo. Com isso é possível notar que os valores obtidos neste trabalho estão coerentes com a faixa de valores de condutividade para areias. 


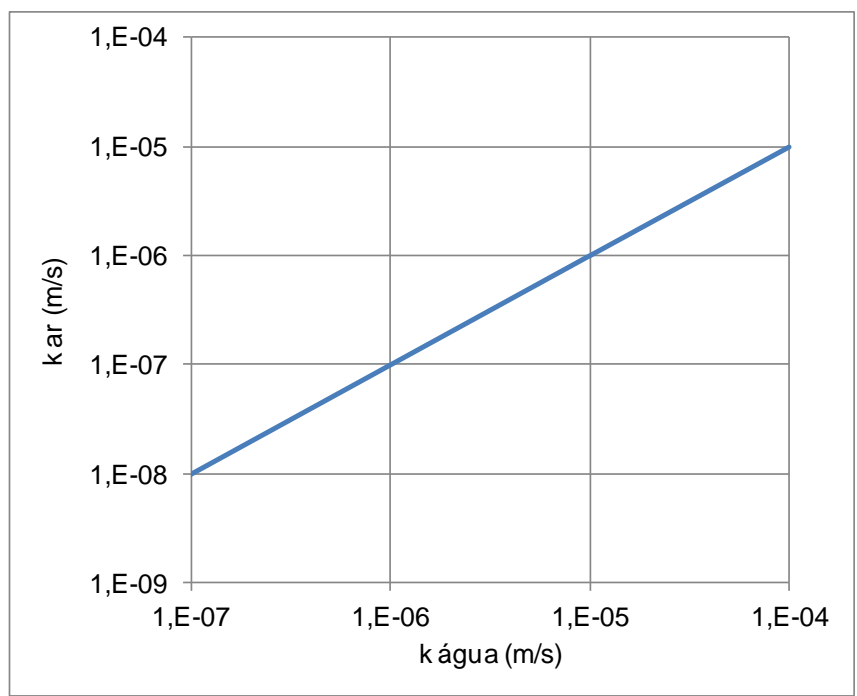

Figura 6.3 - Relação teórica entre a condutividade á água versus condutividade ao ar.

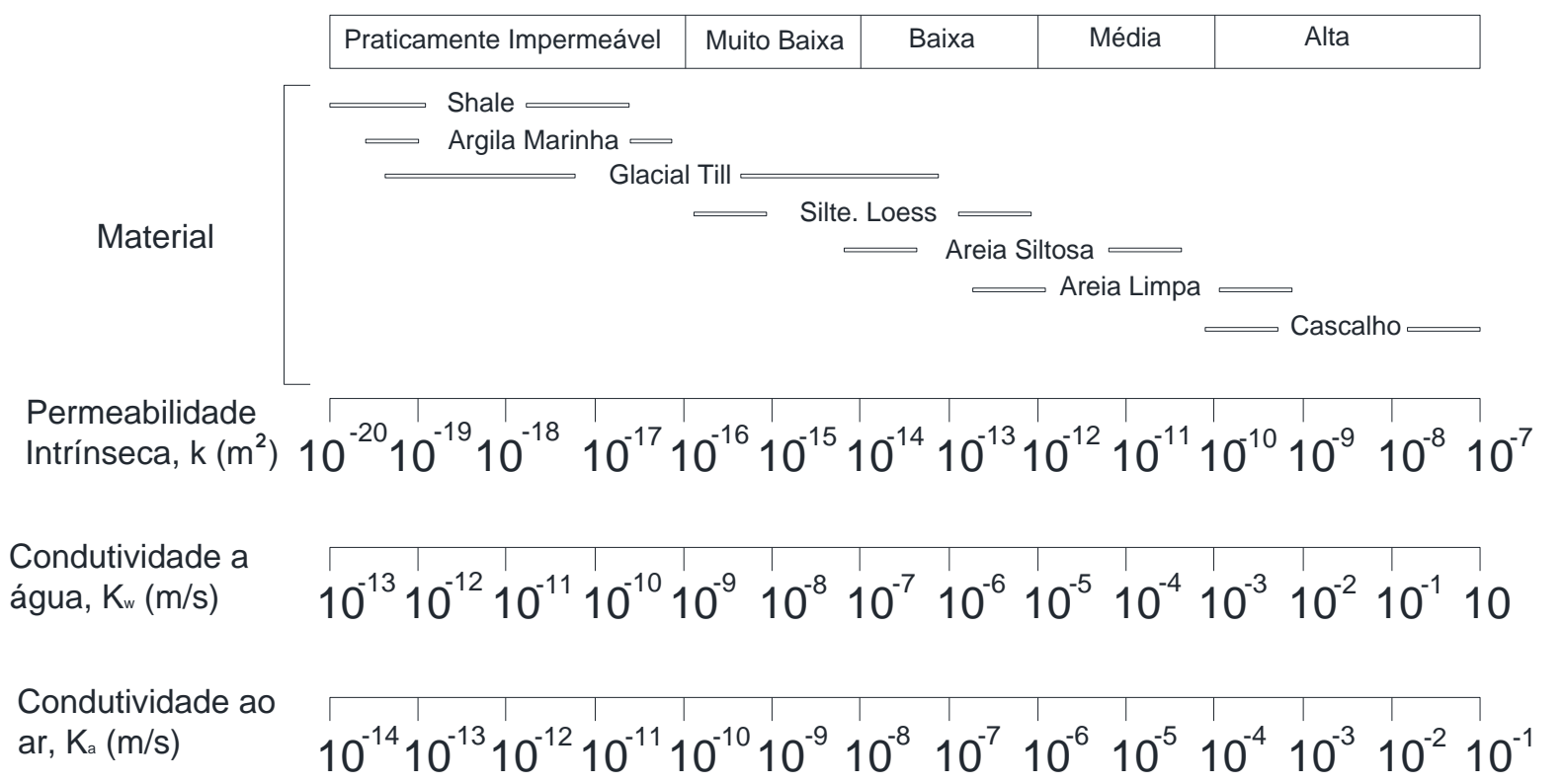

Figura 6.4 - Relação entre a permeabilidade intrínseca, a condutividade a água e ao ar. (modificado de EPA, 1996)

Por ser mais simples e rápido, tem-se preferido fazer ensaios com ar ao invés de água para se determinar a permeabilidade intrínseca $(k)$ do solo. Com esse valor de $k$ pode-se calcular a condutividade hidráulica $\left(\mathrm{K}_{\mathrm{w}}\right)$ do solo através da equação (6.11) apenas trocando a densidade e a viscosidade do ar pela da água. Salienta-se que para solos que contraem este procedimento não é adequado.

Alguns autores, como por exemplo, Jalbert e Dane (2003) acreditam que valores de condutividade hidráulica $\left(\mathrm{K}_{\mathrm{w}}\right)$ não podem ser diretamente determinados por valores 
de permeabilidade ao ar por causa de fatores como o escorregamento do ar. Valores de permeabilidade determinados com ar em solos secos mesmo assim deveriam ser comparados com valores de permeabilidade determinados com água em solos saturados, assumindo que não haja interação água-sólido.

A permeabilidade ao ar é baseada na Lei de Darcy, essa lei assume que o regime de fluxo é laminar, porém isso não acontece em todos os poros do solo; quando o tamanho do poro é da mesma ordem de magnitude do caminho médio livre que o ar pode percorrer então há algum fluxo molecular que não segue a Lei de Darcy. É por causa disso que a permeabilidade varia com a pressão aplicada. Nos ensaios realizados no Laboratório de Mecânica dos Solos (LMS) nota-se que a permeabilidade ao ar varia com a pressão, quanto maior a pressão aplicada menor a permeabilidade ao ar.

O caminho médio livre é a média das distâncias percorridas por uma partícula (átomo ou molécula) entre impactos sucessivos nas paredes (grãos). Estes impactos modificam a direção do movimento.

Em baixas pressões o caminho médio livre aumenta causando um aumento na permeabilidade ao ar, já em pressões altas a permeabilidade ao ar diminuiu até que uma pressão média infinita seja atingida, onde o caminho médio livre é reduzido à zero, e então as moléculas do gás se comportam como líquido, nesse ponto a permeabilidade do gás e do líquido inerte devem ser a mesma.

Klinkenberg em 1941 percebeu que as discrepâncias encontradas em resultados de permeabilidade ao ar e água eram devido à natureza do líquido, e que pareciam invalidar a Lei de Darcy. McPhee e Arthur (1991) mencionaram que a determinação dos parâmetros de Klinkenberg (b e $k_{\text {int }}$ ) é extremamente sensível aos métodos e procedimentos utilizados nos ensaios.

Quando o caminho médio livre é muito menor do que o tamanho do poro, a velocidade de escorregamento pode ser desprezada. E quando o caminho médio livre é muito maior do que o diâmetro de capilaridade pode-se dizer que o fluxo é de 
Knudsen. Existem vários métodos para se calcular o fluxo não viscoso. $\mathrm{O}$ mais usado é a equação abaixo proposta por Klinkenberg.

$$
\begin{gathered}
k_{\text {gás }}=k_{\text {int }}\left[1+\frac{b}{P_{m}}\right] \\
P_{m}=\frac{P_{e}+P_{s}}{2}
\end{gathered}
$$

$k_{\text {gás }}-$ permeabilidade aparente ao ar,

$k_{\text {int }}$ - coeficiente de permeabilidade intrínseca ou também conhecido como coeficiente de Klinkenberg,

$P_{m}$ - pressão média absoluta entre as duas faces da amostra,

$P_{e}$ - pressão absoluta de entrada de ar,

$P_{s}$ - pressão absoluta de saída de ar (que no presente estudo é a pressão atmosférica),

$b$ - fator de Klinkenberg.

O fator de Klinkenberg (b) depende da estrutura do poro e das características do gás percolante. Quanto mais alta for à permeabilidade da amostra menor será o valor de b, ou seja, b aumenta com a diminuição dos tamanhos dos poros. Em condições isotermas, o caminho médio livre é inversamente proporcional a pressão. $O$ valor de b pode ser calculado pela seguinte equação:

$$
b=\frac{4 c \tau P_{m}}{r}
$$

$r$ - raio capilar ou raio do poro,

$\tau$ - caminho médio livre,

$c$ - fator de proporcionalidade.

O efeito Klinkenberg ou efeito de escorregamento do gás ocorre a baixas pressões quando o caminho médio livre das moléculas fica da mesma ordem de grandeza do diâmetro dos poros e o gás escoa por eles com velocidades superiores às descritas pela Lei de Darcy, isso pode causar um desvio do comportamento linear. É devido a esse efeito que ensaios de permeabilidade usando gases apresentam valores 
maiores do que os reais, o que não acontece para líquidos; também é por causa desse efeito que a velocidade do gás nas paredes do poro não pode ser assumida como zero, resultando em fluxos de maior magnitude do que o previsto pela Lei de Darcy. $O$ efeito de Klinkenberg é mais significativo em solos argilosos.

$O$ método para a determinação do coeficiente de permeabilidade intrínseca $\left(k_{\text {int }}\right)$ consiste em medir o $k$ em diferentes pressões e plotar um gráfico contra o inverso da pressão média aplicada. Klinkenberg mostrou que, plotando um gráfico como o descrito acima, se obtém uma reta e o $k_{\text {int }}$ é obtido pela extrapolação quando $1 / P_{m}=0$, ou seja, $P_{m} \rightarrow \infty$, e $b$ é a inclinação dessa reta.

Segundo estudos de Jones e Owens (1980) realizados em 100 amostras, o melhor ajuste para o valore de $b$ é:

$$
b=0,86 * k_{\text {int }}^{-0,33}
$$

Já estudos feitos por Jones (1972) também em 100 amostras, mostraram que o $b$ é:

$$
b=6,9 * k_{\text {int }}^{-0,36}
$$

Considerando $b$ em psi e $k_{\text {int }}$ em milidarcy.

Jannot et al. (2007) converteu a equação (6.16) para o SI (b em Pa e $k_{\text {int }}$ em m²) portanto temos que:

$$
b=1,89 * 10^{-1} * k_{\text {int }}^{-0,36}
$$

As análises apresentadas neste trabalho foram feitas considerando a equação (6.17).

\subsubsection{Descrição do equipamento}

O diâmetro máximo do corpo de prova para o ensaio no equipamento disponível é de $3,5 \mathrm{~cm}$. As pedras porosas utilizadas foram fabricadas no LMS com areia e resina 
epóxi. A pressão confinante e a pressão de injeção de ar aplicadas foram controladas através de dois manômetros; que podem ser vistos na parte superior da Figura 6.5; e que estão conectadas ao equipamento. A pressão de ar é aplicada na base do corpo de prova e a pressão de saída é a pressão atmosférica.

As leituras de vazão foram feitas com auxílio de um equipamento eletrônico (Film Flow Meter VP-4 da Horibastec) que mede vazões de 0,2 a $10 \mathrm{l} / \mathrm{min}$. A vazão é calculada pelo aparelho, que tendo um volume interno definido mede o tempo que uma bolha de sabão leva de um ponto a outro. Tal equipamento encontra-se no lado direito da Figura 6.5.

No estudo o gás que saía da amostra ia diretamente para a atmosfera, ou seja, a pressão média e a vazão foram controladas apenas pela taxa de injeção de ar.

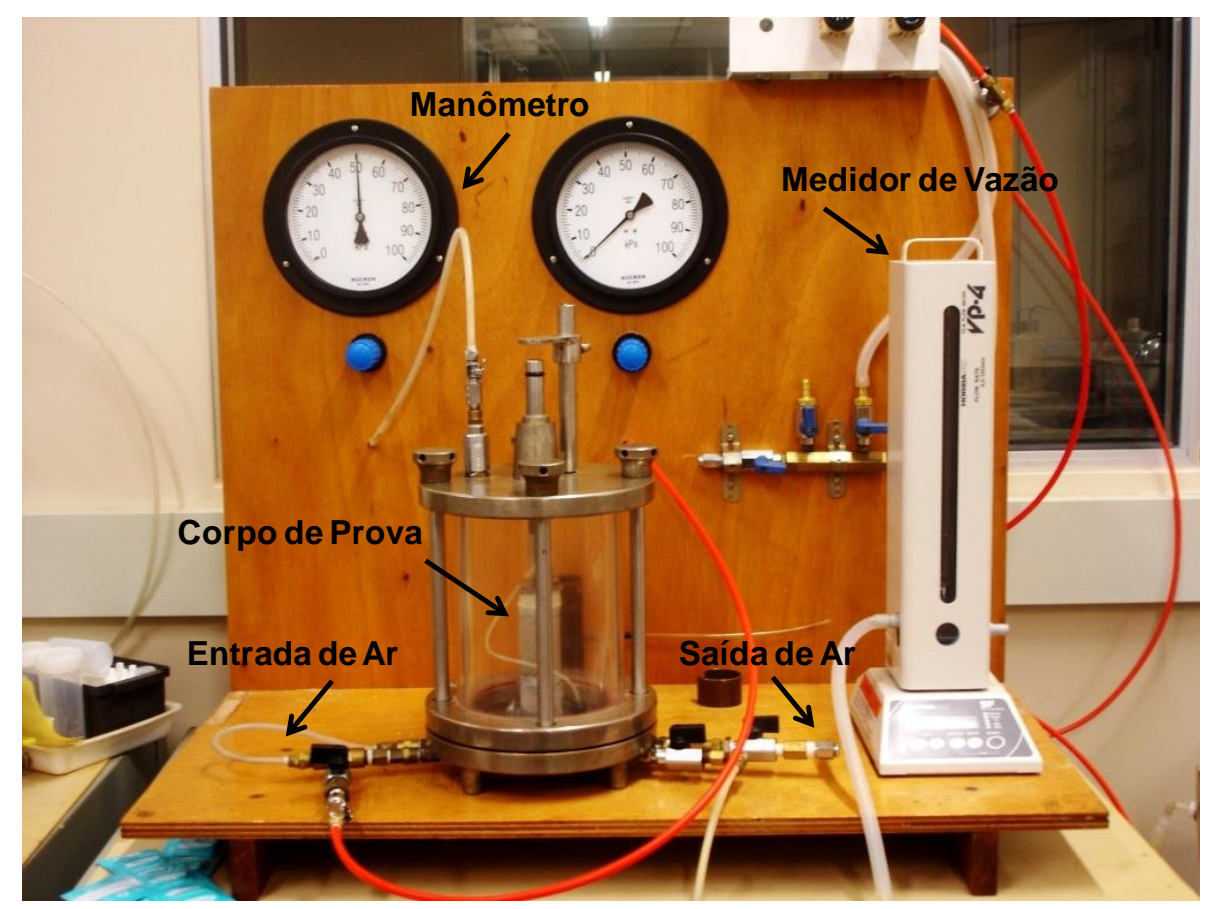

Figura 6.5 - Equipamento utilizado no ensaio de permeabilidade ao ar.

\subsubsection{Moldagem dos corpos de prova}

No ensaio o solo fica envolto lateralmente por uma membrana flexível de látex impermeável que é fixada através de anéis de vedação (“o-ring”), ver Figura 6.6-(b). A membrana serve para obrigar o ar a passar pela amostra durante o ensaio. Se houver algum furo nela é necessária a troca da mesma e um novo ensaio é 
realizado. Coloca-se uma pedra porosa na base e outra no topo da amostra para uniformizar a difusão e coleta do fluxo de ar, na Figura 6.6-(a) pode-se ver a pedra porosa na base e na Figura 6.6-(e) a de topo. Depois de colocada a pedra porosa da base e a membrana flexível de látex, já presa na base com um "o-ring" coloca-se um molde tri-partido, com diâmetro de $3,5 \mathrm{~cm}$ e altura de $5 \mathrm{~cm}$, ver Figura 6.6-(c). Depois disso o corpo de prova foi compactado em camadas de forma a atingir 0 índice de vazios desejado, conforme ilustra a Figura 6.6-(d). Terminada a compactação coloca-se a pedra porosa de topo e o cabeçote; que está conectado ao aparelho que mede as vazões; terminado isso se aplica vácuo para manter a amostra coesa e tira-se o molde tri-partido. Na Figura 6.6-(f) pode ser observada uma parte do molde já retirado do corpo de prova. Quando o molde é retirado completamente coloca-se uma célula triaxial e aplica-se uma confinante de $50 \mathrm{kPa}$, e o vácuo é desligado. Os ensaios foram realizados com a pressão confinante de 50 $\mathrm{kPa}$ e pressões de ar de 3, 4, 5, 7, 9, 10, 20, 30 e $40 \mathrm{kPa}$. 
Capítulo 6 - Ensaios de Laboratório e Resultados
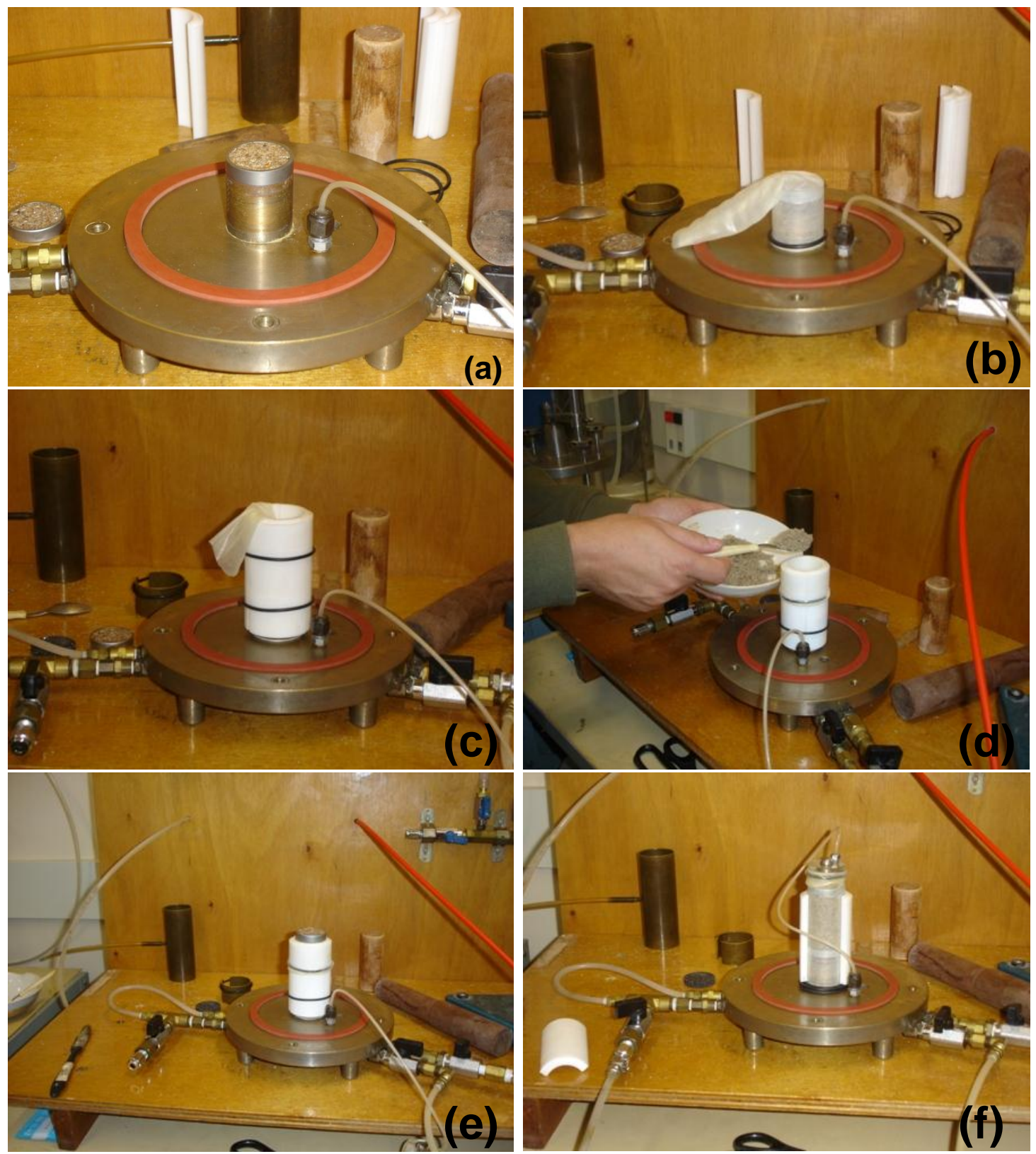

Figura 6.6 - Montagem do ensaio de permeabilidade ao ar

\subsection{Resultados dos ensaios com a Areia Osasco}

$\mathrm{Na}$ Tabela 6.1 podem ser vistos os valores que deram origem à curva granulométrica da Figura 6.7. 
Capítulo 6 - Ensaios de Laboratório e Resultados

Tabela 6.1 - Dados da curva granulométrica

\begin{tabular}{ccc}
\hline Porcentagem que passa & Diâmetro dos grãos (mm) & \# Peneira \\
\hline 100 & 4,80 & 4 \\
98,77 & 2,00 & 10 \\
90,88 & 1,20 & 16 \\
58,54 & 0,60 & 30 \\
32,75 & 0,42 & 40 \\
22,23 & 0,30 & 50 \\
3,53 & 0,15 & 100 \\
0,27 & 0,075 & 200
\end{tabular}

A Areia Osasco é composta de $12 \%$ de areia fina, $48 \%$ de areia média e $39 \%$ de areia grossa, portanto sendo classificada como areia média à grossa; com coeficiente de uniformidade $\left(C N U=D_{60} / D_{10}\right)$ de aproximadamente 3 e $D_{50}=0,48$.

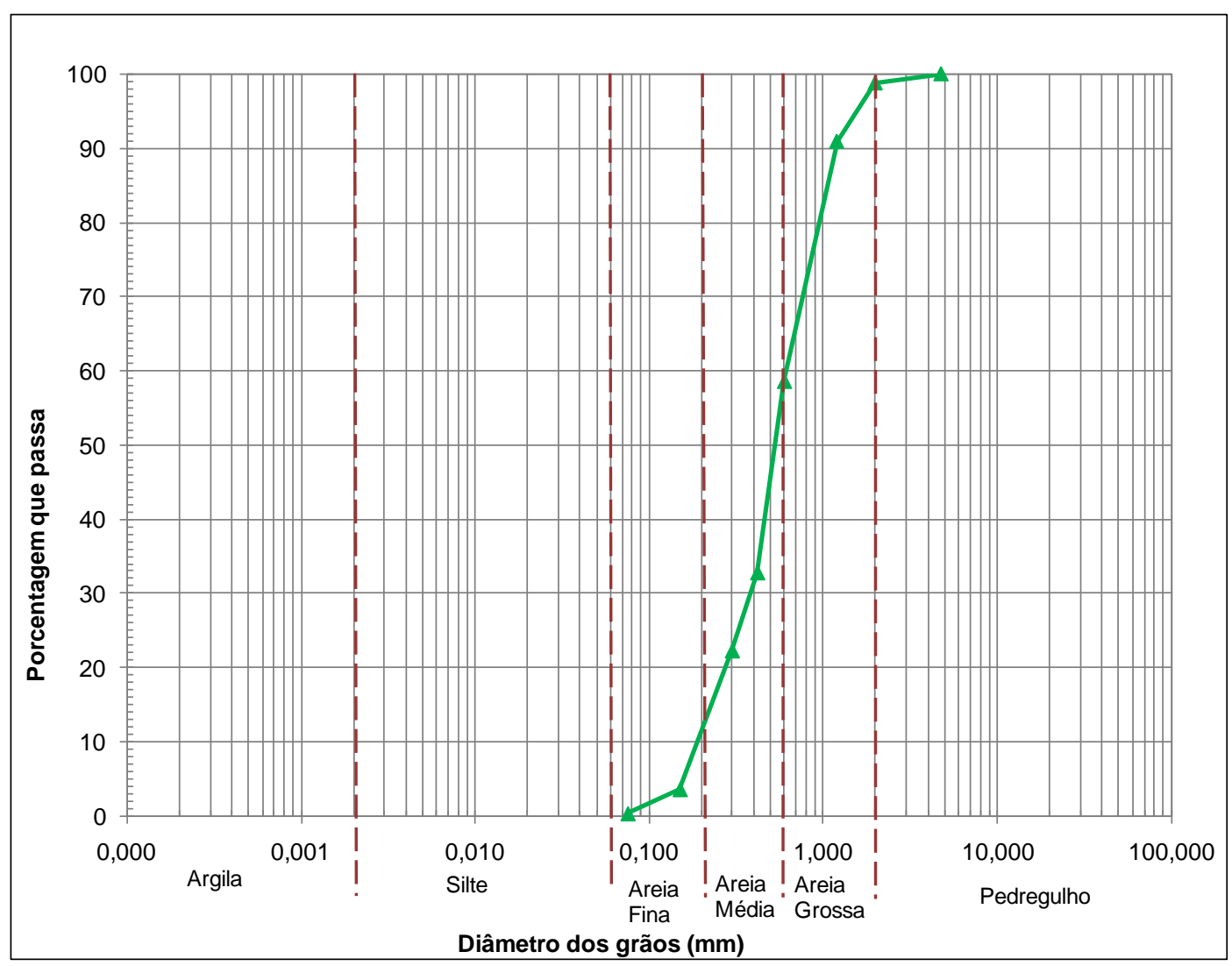

Figura 6.7 - Curva granulométrica da areia Osasco. 
A densidade dos grãos $\left(\gamma_{s}\right)$ foi determinada segundo a norma NBR 6508/1982 e o resultado obtido foi de $2,65 \mathrm{~g} / \mathrm{cm}^{3}$.

Para a obtenção do índice de vazios máximo foram utilizados dois métodos, que se encontram descritos na norma MB 3324/1990 o método "A" que é o método do funil e o método "B" que é o método do tubo de PVC. Para a determinação do índice de vazios mínimo também foram utilizados dois métodos, um deles é o método "B" da norma MB 3388/1991 que é o ensaio de mesa vibratória e o outro método é do soquete de madeira em solo saturado, empregado por Sousa Pinto. Os procedimentos e resultados completos podem ser vistos em Teixeira (2008). A Tabela 6.2 apresenta um resumo dos resultados dos ensaios de índice de vazios máximo e mínimo.

Tabela 6.2 - Resultado dos ensaios de índice de vazios máximo e mínimo (dados obtidos de Teixeira, 2008).

\begin{tabular}{lc}
\hline \multicolumn{2}{l}{ Índice de vazios máximo e mínimo } \\
\hline$e_{\text {máx }}$ funil & 0,826 \\
e $_{\text {máx }}$ tubo de PVC & 0,807 \\
$e_{\min }$ soquete saturado & 0,584 \\
$e_{\min }$ mesa vibratória & 0,567 \\
\hline
\end{tabular}

A Tabela 6.3 apresenta os dados obtidos do ensaio de retenção de água. Para cada sucção foram realizadas pesagens para a determinação do teor de umidade, grau de saturação e teor de umidade volumétrica. 


\begin{tabular}{|c|c|c|}
\hline \multicolumn{3}{|c|}{ correspondentes, dados da curva de retenção de água. } \\
\hline Sucção (kPa) & Saturação (\%) & $\begin{array}{c}\text { Saturação } \\
\text { volumétrica }(\theta)\end{array}$ \\
\hline 0,1 & 98,8 & 0,39 \\
\hline 0,2 & 95,7 & 0,38 \\
\hline 0,3 & 93,32 & 0,38 \\
\hline 0,5 & 88 & 0,35 \\
\hline 1 & 74,9 & 0,30 \\
\hline 2 & 64,6 & 0,25 \\
\hline 3 & 47 & 0,19 \\
\hline 5 & 11,7 & 0,05 \\
\hline 8 & 10,2 & 0,04 \\
\hline 10 & 9,5 & 0,04 \\
\hline 20 & 4,5 & 0,02 \\
\hline 30 & 3,8 & 0,01 \\
\hline
\end{tabular}

A Figura 6.8 apresenta a curva de retenção de água da Areia Osasco em termos de grau de saturação a água. É possível notar que para areias depois de atingida a sucção correspondente a da entrada de ar o solo dessatura rapidamente o que pode ser observado na Figura 6.8. Essa queda brusca na saturação ocorre devido à pequena variação entre os diâmetros dos poros comumente encontrada em areias. 
Capítulo 6 - Ensaios de Laboratório e Resultados

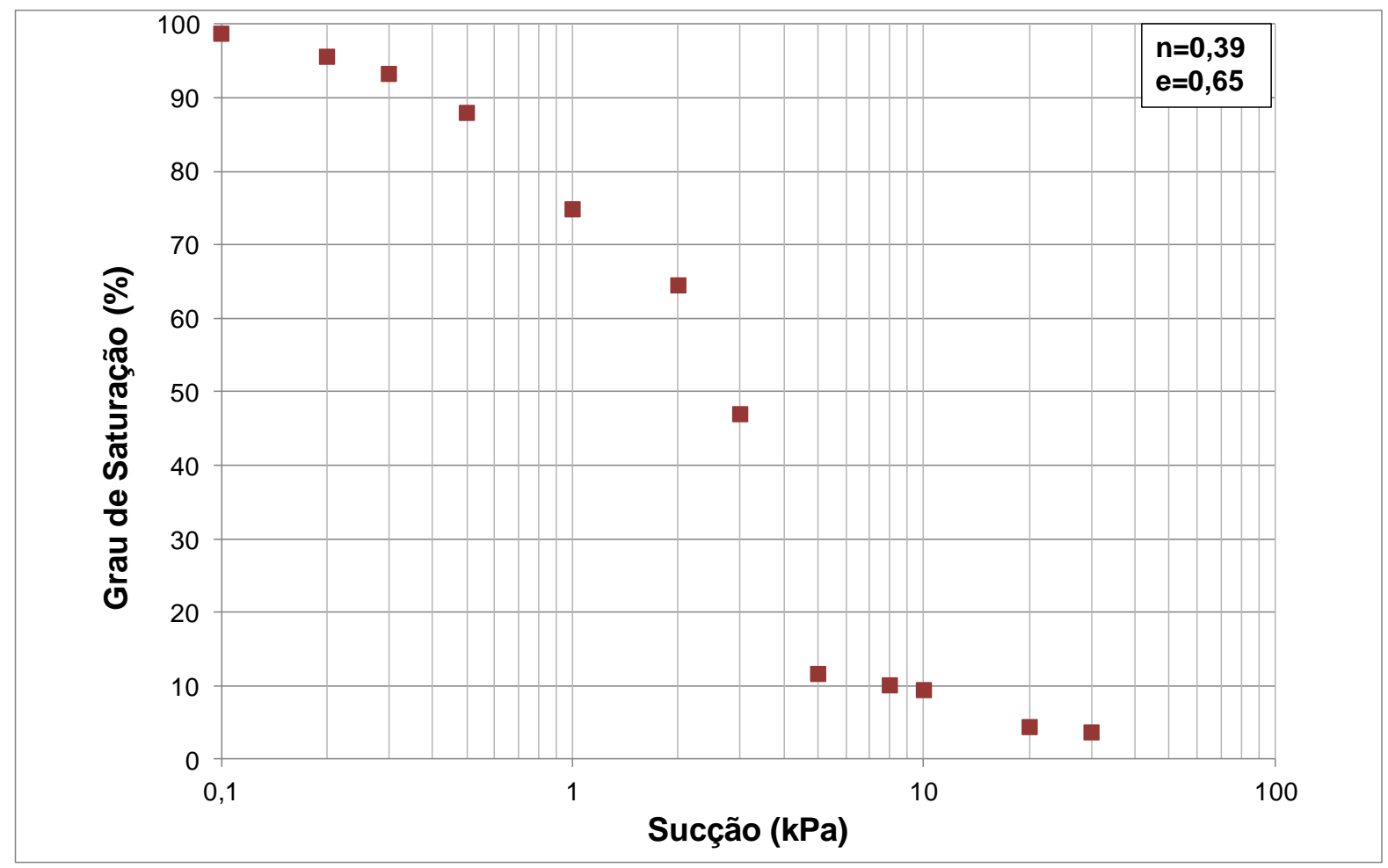

Figura 6.8 - Curva de retenção de água da Areia Osasco em termos de saturação.

Já a Figura 6.9 apresenta a curva de retenção de água da Areia Osasco em termos de teor de umidade volumétrica $(\theta)$.

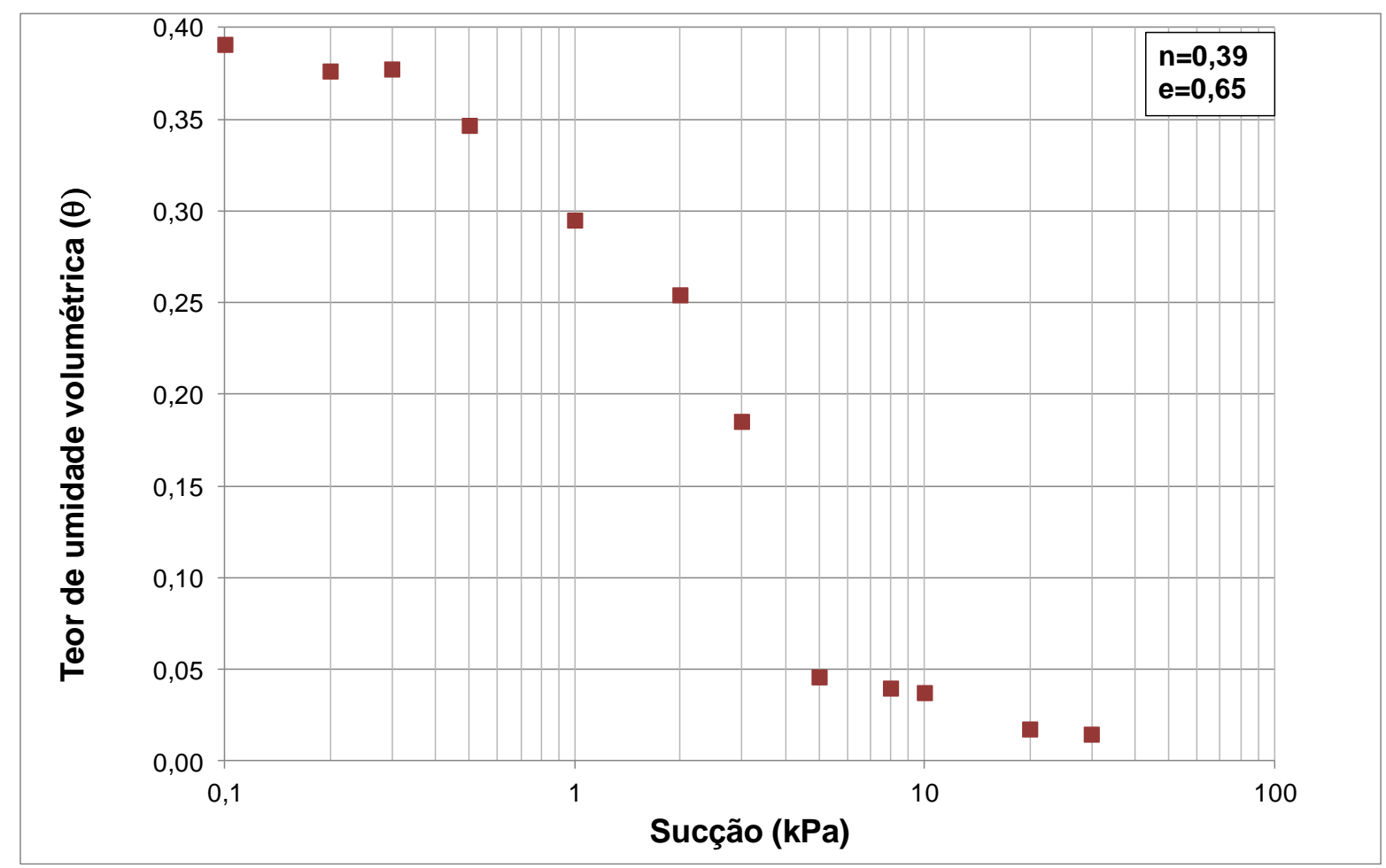

Figura 6.9 - Curva de retenção de água da Areia Osasco em termos de teor de umidade volumétrica. 
O gráfico do modelo de Brooks e Corey apresentado na Figura 6.10 foi construído através da equação (5.2). Os parâmetros do modelo proposto por Brooks e Crey (1964) encontrados para a Areia Osasco foram: a pressão de entrada de $\operatorname{ar}\left(\psi_{\mathrm{b}}\right)$ de 1 $\mathrm{kPa}$, o teor de umidade volumétrico residual $\left(\theta_{r}\right)$ é de $0,05 \%$, o índice de distribuição dos poros $(\lambda)$ é 1,3 e o teor de umidade volumétrica equivalente a saturação completa $(\theta s)$ é 0,357 . O baixo valor de $\psi_{b}$ encontrado para a Areia Osasco indica que o solo possui poros largos o que era de se esperar para uma areia.

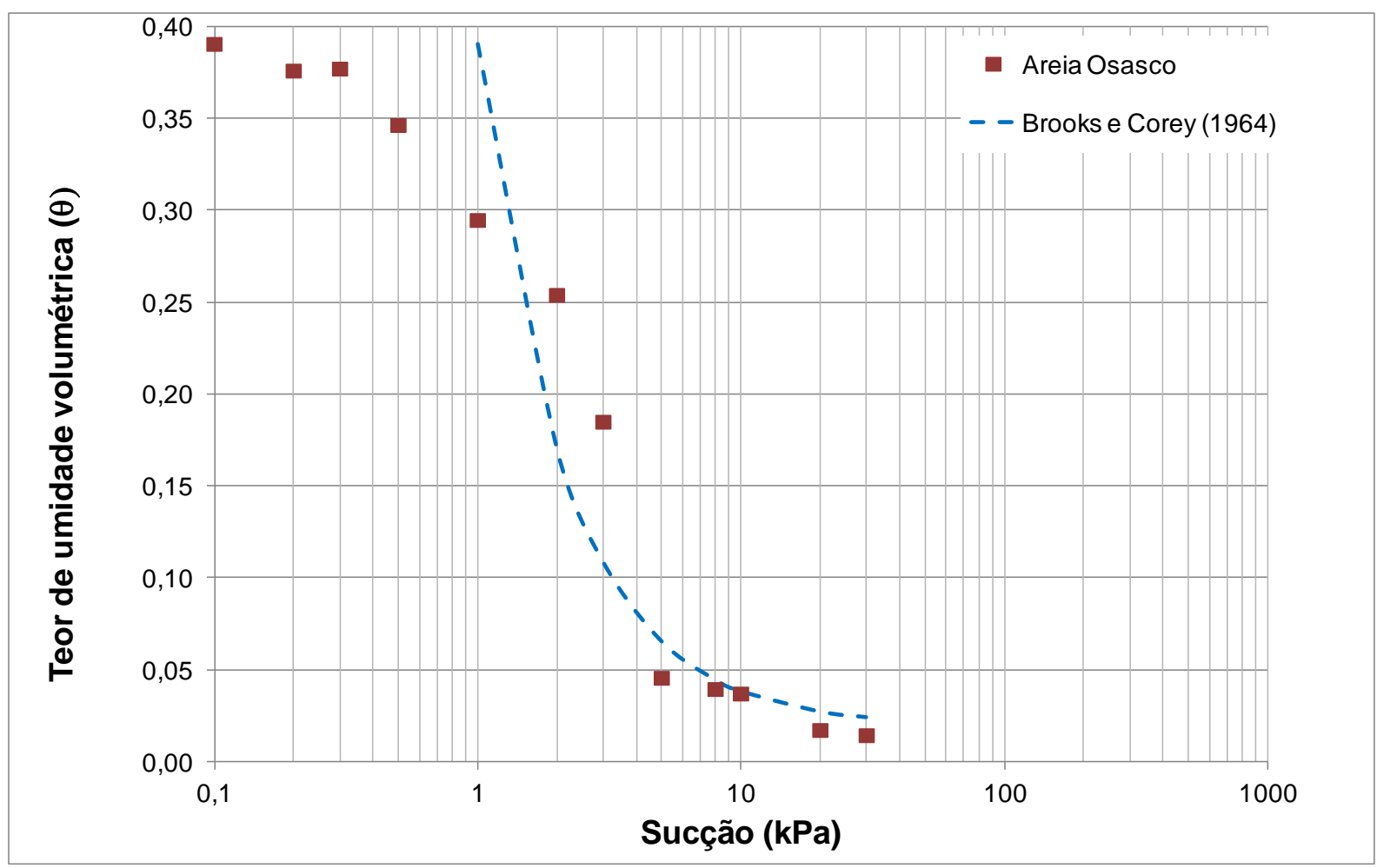

Figura 6.10 - Curva de retenção de água da Areia Osasco e o ajuste do modelo de Brooks e Corey.

Na Figura 6.11 pode ser comparada a curva de retenção, obtida através do ensaio com a placa de sucção, com a curva determinada pelo modelo do programa Splintex, desenvolvido por PREVEDELLO, 2002, que estima a curva de retenção de água do solo utilizando a granulometria do solo e a geometria dos poros. 


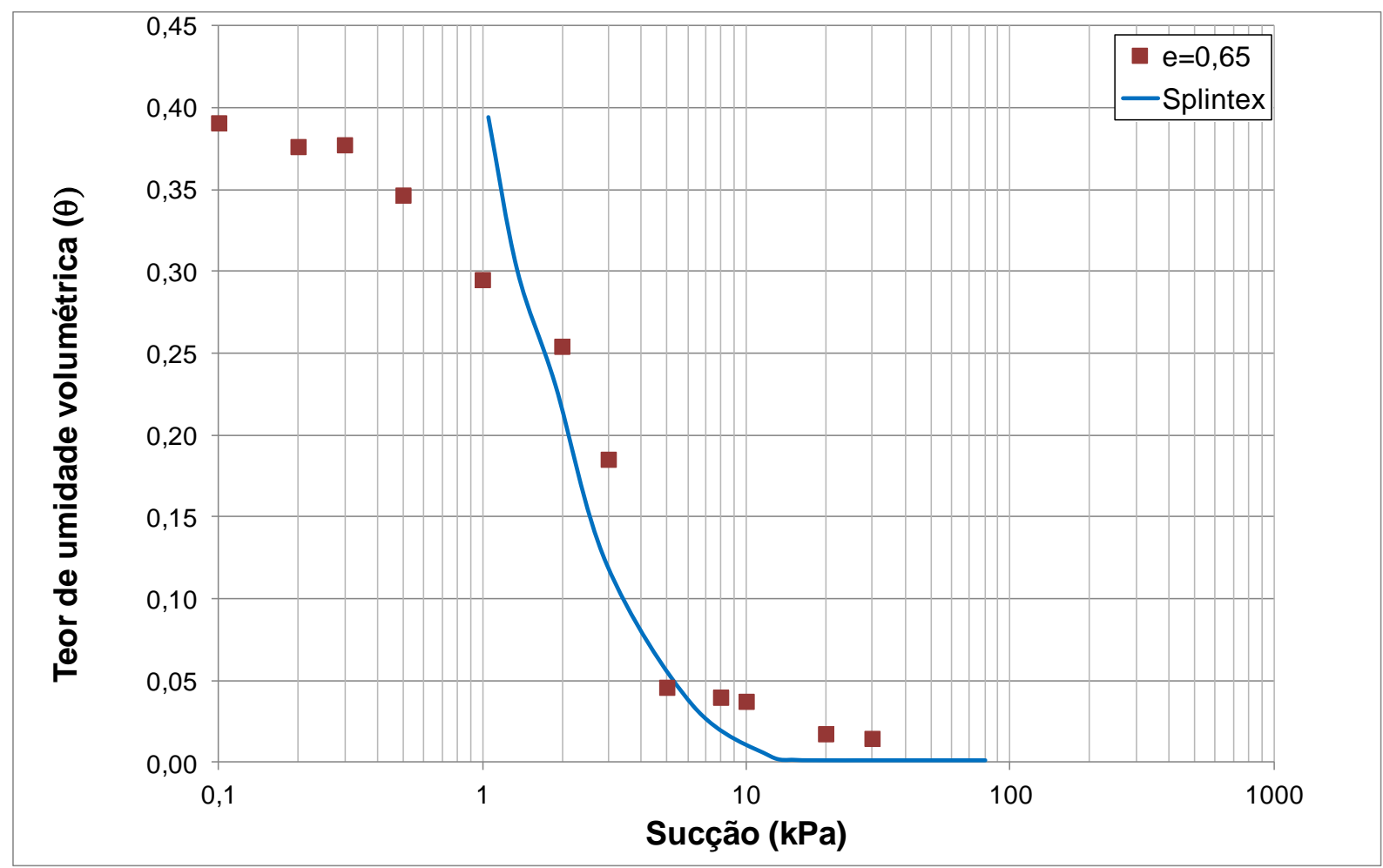

Figura 6.11 - Curva de retenção de água da Areia Osasco e o ajuste do modelo pelo Splintex.

Para os ensaios de permeabilidade ao ar os índices de vazios dos corpos de prova utilizados foram de aproximadamente 0,65. Foram feitos ensaios com várias saturações de água para analisar a variação da permeabilidade ao ar com o grau de saturação do solo. Os ensaios foram realizados com uma confinante de $50 \mathrm{kPa}$, e com pressões de entrada de 3, 4, 5, 7, 9, 10, 20, 30 e $40 \mathrm{kPa}$; variando as saturações de água das amostras, as saturações utilizadas foram 0, 20, 50, 60 e $70 \%$. Na saturação de $70 \%$ com pressões acima de $9 \mathrm{kPa}$ o ensaio não conseguiu ser realizado, pois no local de saída de ar da amostra para o aparelho que realiza a leitura notou-se que junto com o ar também saía água, e por esse motivo o ensaio foi interrompido. Isso também aconteceu para a saturação de 60 \% com pressões acima de $20 \mathrm{kPa}$.

A permeabilidade ao ar de um solo depende da quantidade e do formato dos poros contidos na amostra. A permeabilidade ao ar também varia com a saturação do corpo de prova, quanto mais saturado ele estiver menor é a permeabilidade ao ar, pois o ar tem maior dificuldade de passar já que os poros do solo estão preenchidos com água; isso pode ser visto na Figura 6.12. É possível perceber através da curva de retenção do solo que se for aplicada uma pressão maior do que $3 \mathrm{kPa}$ na Areia 
Osasco com uma saturação acima de $20 \%$ o ar ao passar pela amostra irá arrastar um pouco da água fazendo com que a saturação inicial caia. É por isso que não se conseguiu ir além do grau de saturação da ordem de $70 \%$. Ainda na Figura 6.12 são apontados os resultados da condutividade ao ar para diversos graus de saturação a diferentes pressões de injeção. Observa-se que para saturações maiores do que aproximadamente $70 \%$ a condutividade tende a cair rapidamente. $O$ efeito da pressão de ar pode ser observado na redução do valor de $\mathrm{K}_{\mathrm{a}}$ para o mesmo grau de saturação.

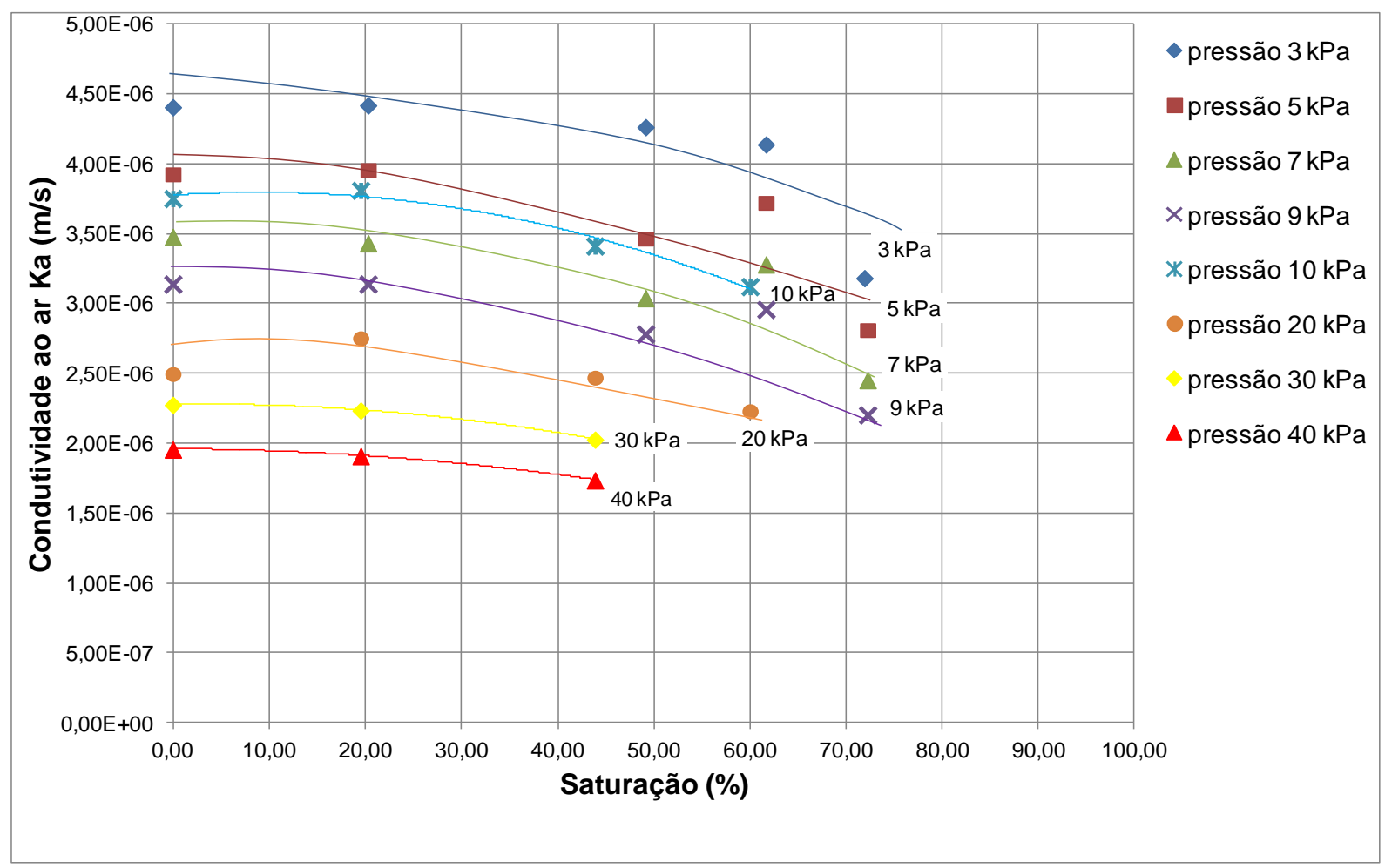

Figura 6.12 - Gráfico mostrando a variação da Condutividade ao ar com a saturação de água para a Areia Osasco.

Na Figura 6.13 é apresentada a relação entre a permeabilidade intrínseca e o inverso da pressão média para as saturações em que os ensaios foram realizados. Desse gráfico foram obtidos os valores aproximados do $k_{\text {int }}$ e b, $1,6 \times 10^{-12} \mathrm{~m}^{2}$ e 3,3 $\mathrm{kPa}$, respectivamente. Não foi possível diferir claramente o efeito do grau de saturação nesta análise, embora haja uma tendência de diminuição do $k_{\text {int }}$ com o aumento da saturação. 
Capítulo 6 - Ensaios de Laboratório e Resultados

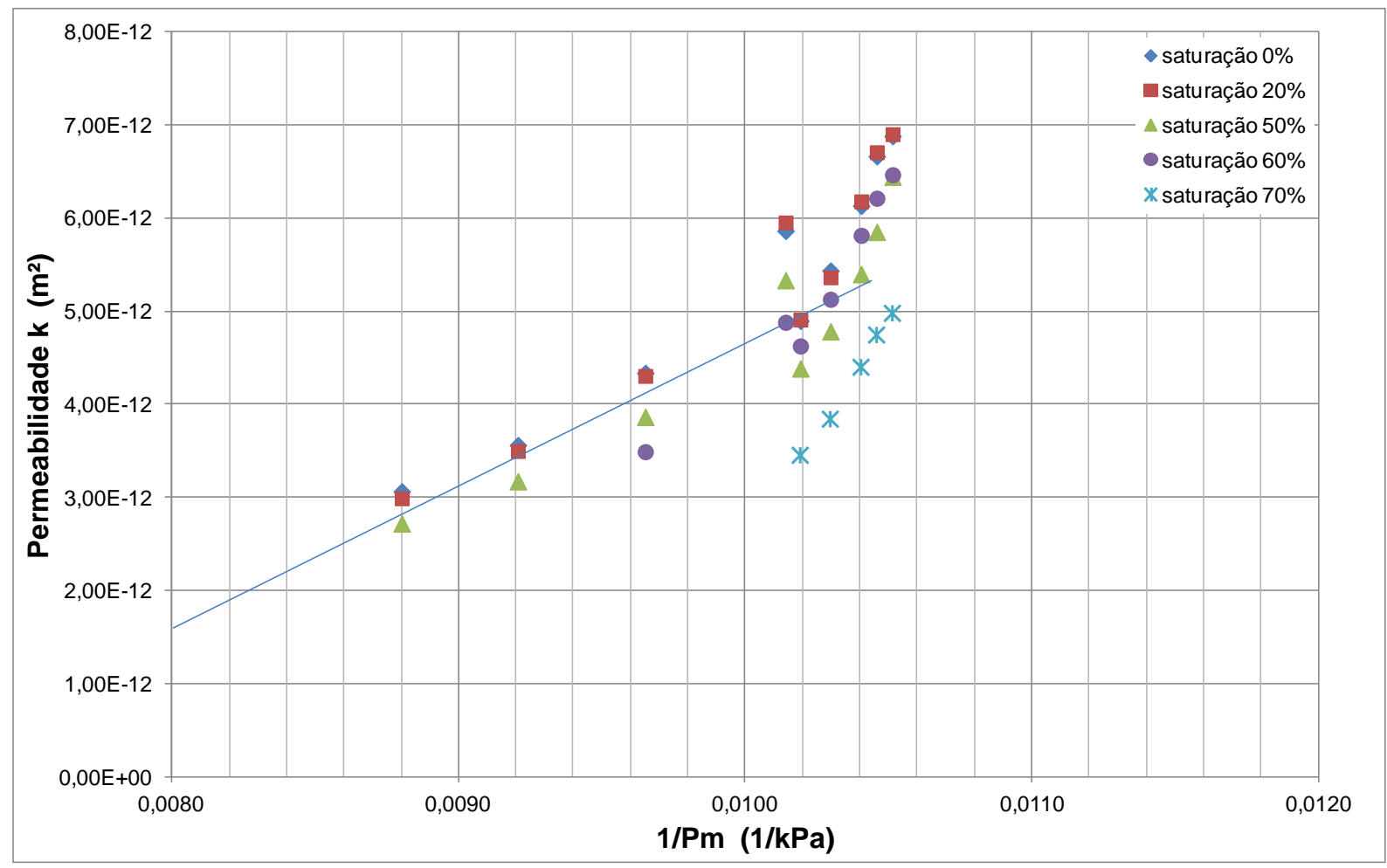

Figura 6.13 - Gráfico da permeabilidade intrínseca versus o inverso da pressão média, para a Areia Osasco.

Os ensaios de permeabilidade a água foram feitos segundo a norma NBR-13292, os ensaios foram realizados com o índice de vazios máximo, mínimo e com o índice de vazios equivalente a compacidade relativa de $70 \%$. A Tabela 6.4 mostra os resultados dos ensaios de permeabilidade à água, realizados para a Areia Osasco.

Tabela 6.4 - Condutividade à água encontrada para cada índice de vazios.

\begin{tabular}{cccc}
\hline \multicolumn{2}{c}{ Índice de vazios } & $\mathbf{K}(\mathbf{m} / \mathbf{s}) \mathbf{2 4}^{\circ}$ & $\mathbf{K}(\mathbf{m} / \mathbf{s}) \mathbf{2 0}^{\circ}$ \\
\hline e $_{\text {máximo }}$ & 0,81 & $7,9 \times 10^{-4}$ & $7,2 \times 10^{-4}$ \\
$\mathrm{e}$ & 0,65 & $5,0 \times 10^{-4}$ & $4,5 \times 10^{-4}$ \\
$e_{\text {mínimo }}$ & 0,58 & $2,7 \times 10^{-4}$ & $2,5 \times 10^{-4}$ \\
\hline
\end{tabular}

Na Figura 6.14 pode ser visto o gráfico de condutividade à água versus índice de vazios. 


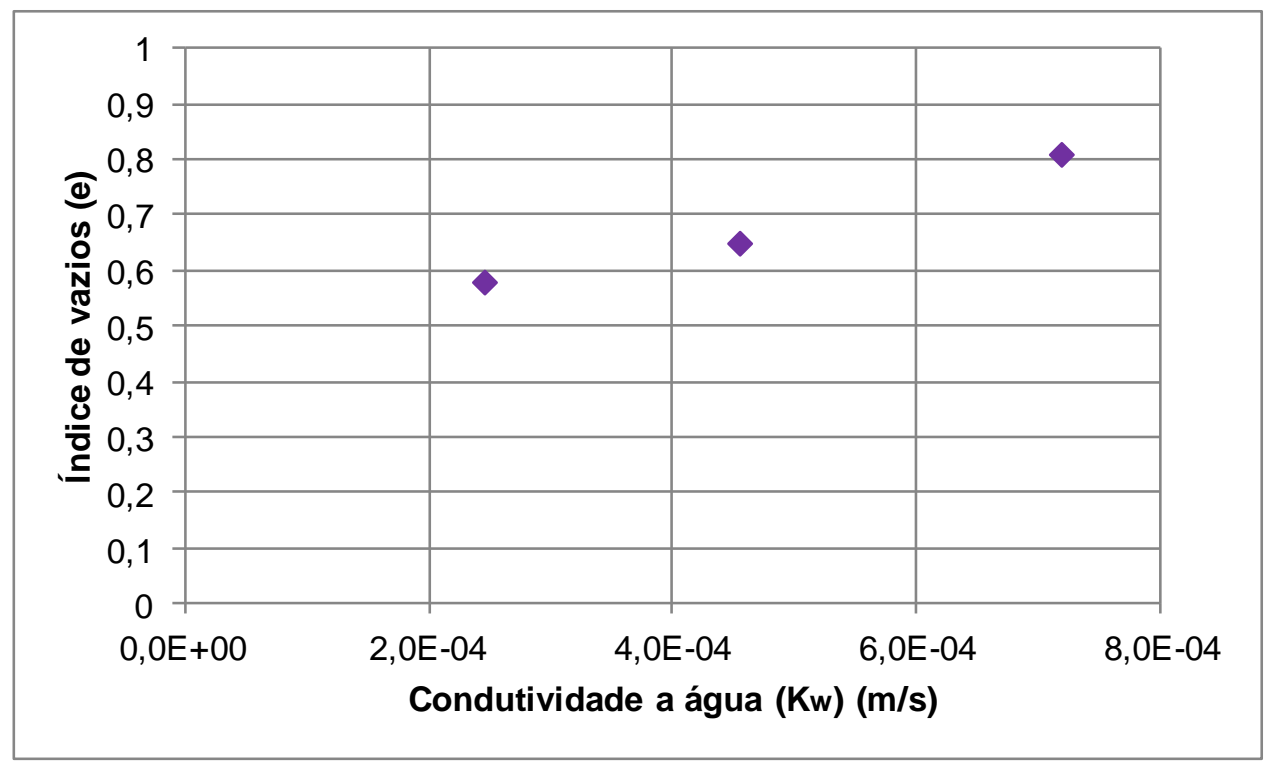

Figura 6.14 - Gráfico da Condutividade a água pelo índice de vazios, Areia Osasco.

\subsection{Resultados dos ensaios com a Areia do IPT}

A Areia do IPT é uma areia comercial e uniforme, na Tabela 6.5 pode ser observado que quase a totalidade dos seus grãos fica retida na peneira de $n^{\circ} 40$.

Tabela 6.5 - Dados da curva granulométrica da Areia do IPT

\begin{tabular}{ccc}
\hline Porcentagem que passa & $\begin{array}{c}\text { Diâmetro dos grãos } \\
(\mathbf{m m})\end{array}$ & \# Peneira \\
\hline 100 & 4,80 & 4 \\
100 & 2,00 & 10 \\
100 & 1,20 & 16 \\
99,93 & 0,60 & 30 \\
48,33 & 0,42 & 40 \\
1,68 & 0,30 & 50 \\
0,08 & 0,15 & 100 \\
0,03 & 0,075 & 200 \\
\hline
\end{tabular}

Essa areia é composta por $99 \%$ de areia média e 1\% de areia fina, portanto sendo classificada como areia média, com coeficiente de uniformidade de 1,3 $\left(C N U=D_{60} / D_{10}\right)$ e $D_{50}=0,43$. A curva granulométrica pode ser observada na Figura 6.15 . 


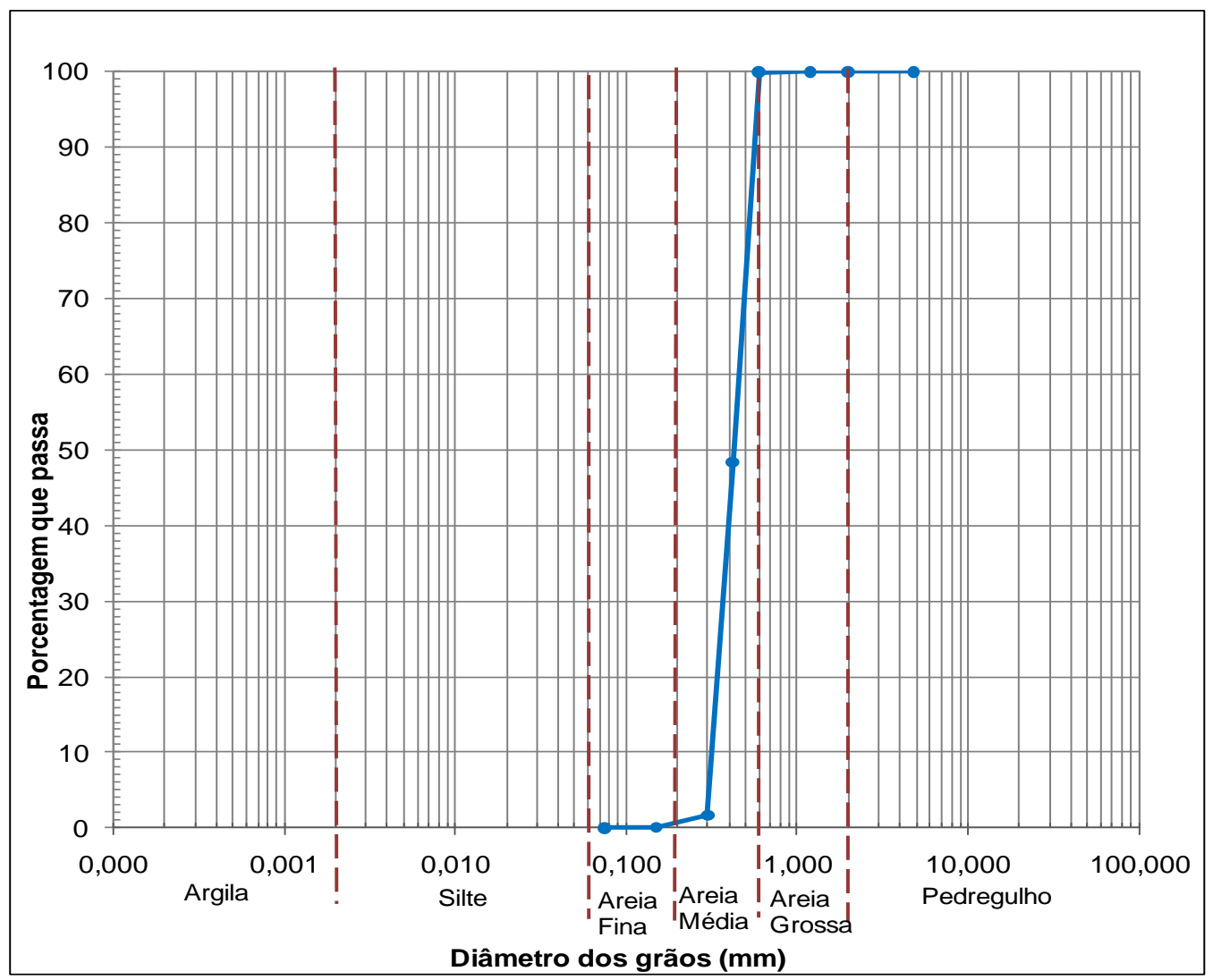

Figura 6.15 - Curva granulométrica da Areia do IPT

A densidade dos grãos $\left(Y_{s}\right)$ foi determinada segundo a norma NBR 6508/1982 e o resultado obtido foi de $2,63 \mathrm{~g} / \mathrm{cm}^{3}$.

Para a obtenção do índice de vazios máximo da Areia do IPT foi utilizado apenas o método "A" descrito na norma MB 3324/1990; e para a determinação do índice de vazios mínimo foi utilizado o método "B" da norma MB 3388/1991 que é o ensaio de mesa vibratória. A Tabela 6.2 apresenta um resumo dos resultados dos ensaios de índice de vazios máximo e mínimo.

Tabela 6.6 - Resultado dos ensaios de índice de vazios máximo e mínimo Areia do IPT.

\begin{tabular}{cc}
\hline Índice de vazios máximo e mínimo \\
\hline $\mathrm{e}_{\text {máx }}$ funil & 0,97 \\
$\mathrm{e}_{\min }$ mesa vibratória & 0,81 \\
\hline
\end{tabular}

Quanto mais uniforme a granulometria de um solo arenoso mais acentuada será a variação entre o teor de umidade volumétrico e a sucção, o que pode ser observado 
Capítulo 6 - Ensaios de Laboratório e Resultados

na Figura 6.16. As areias possuem pequena capacidade de retenção de água devido ao tamanho de seus poros, geralmente grandes, e da alta conectividade entre si.

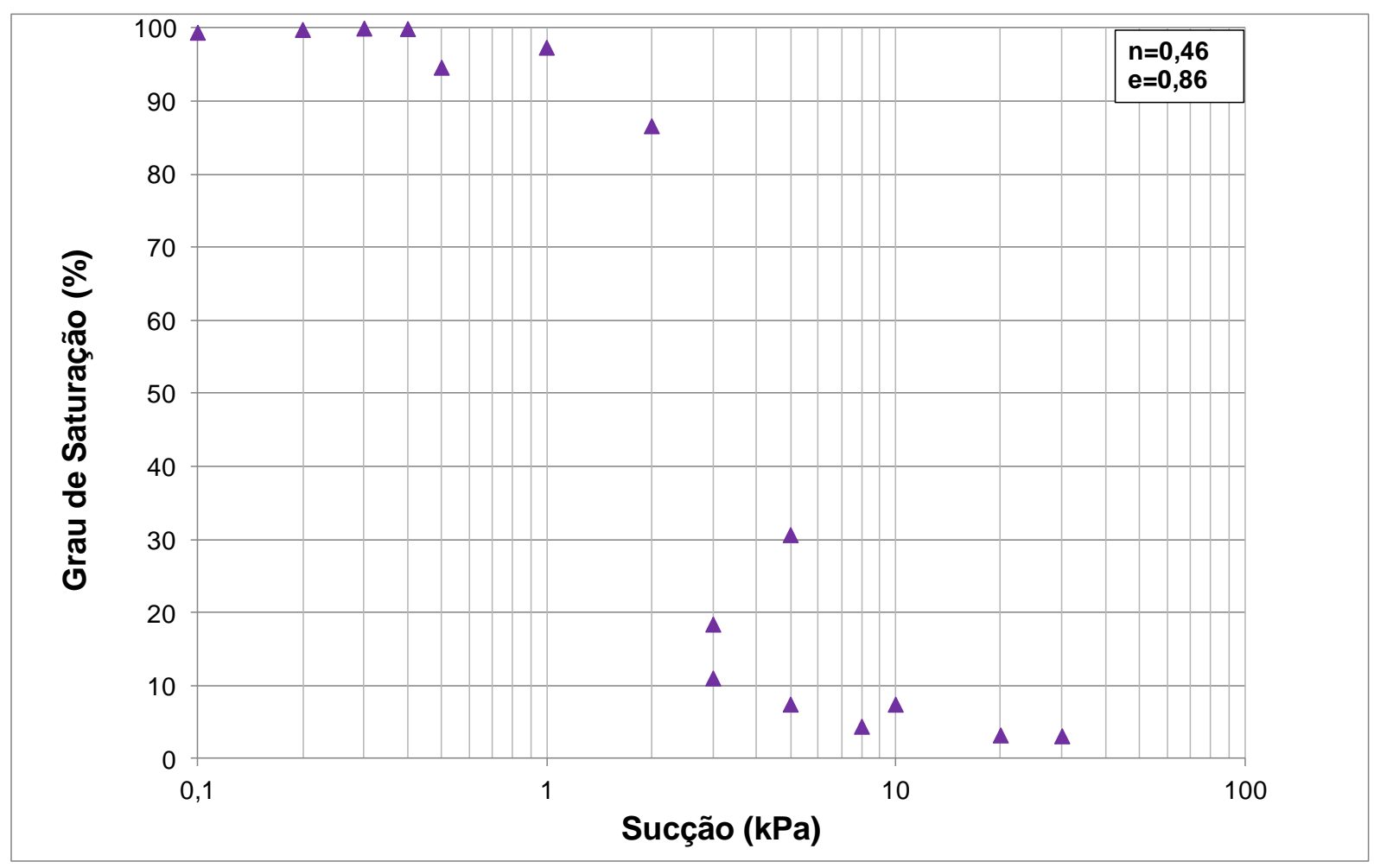

Figura 6.16 - Curva de retenção de água da Areia do IPT em termos de saturação.

A Figura 6.17 mostra a curva de retenção de água da Areia do IPT em termos de umidade volumétrica. 
Capítulo 6 - Ensaios de Laboratório e Resultados

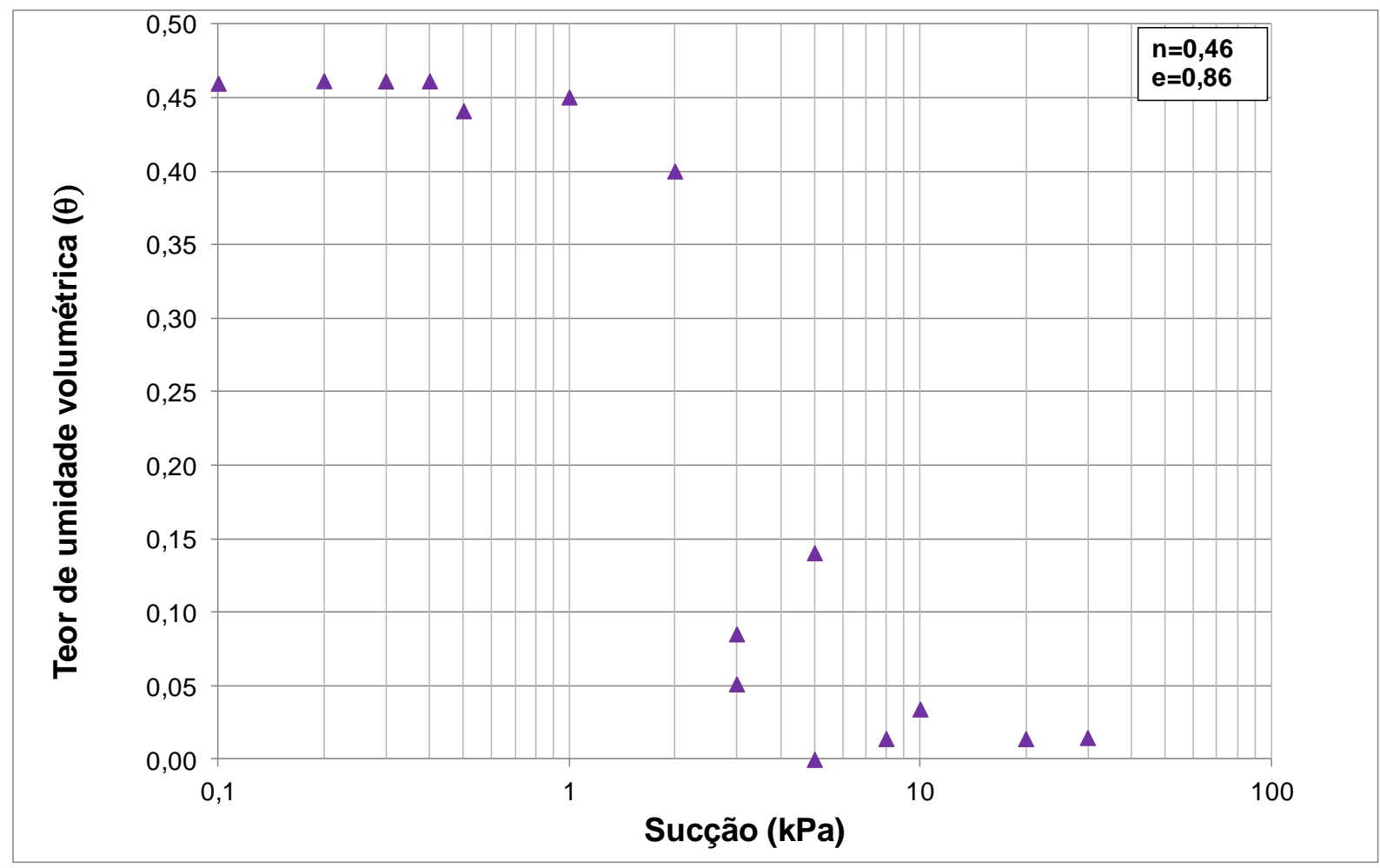

Figura 6.17 - Curva de retenção de água da Areia do IPT em termos de teor de umidade volumétrica.

Altos valores de umidade volumétrica correspondem a baixos valores de sucção, o mecanismo de retenção de água dominante neste caso é a capilaridade, governada principalmente pelas partículas de solo, estruturas dos poros e distribuição granulométrica. É por este motivo que a capilaridade é o mecanismo predominante na retenção de água em areias; que adsorve pouca água por hidratação, ao contrário das argilas que adsorvem bastante água.

Os parâmetros do modelo de Brooks e Corey (1964) para a Areia do IPT foram: a pressão de entrada de $\operatorname{ar}\left(\psi_{\mathrm{b}}\right)$ de $1,5 \mathrm{kPa}$, o teor de umidade volumétrico residual $\left(\theta_{r}\right)$ é de $0,01 \%$, o índice de distribuição dos poros $(\lambda)$ é 1,5 e o teor de umidade volumétrica equivalente a saturação completa $(\theta s)$ é 0,461 . O baixo valor de $\psi_{b}$ encontrado para a Areia do IPT indica que o solo possui poros largos o que era de se esperar para uma areia.

O gráfico do modelo de Brooks e Corey apresentado na Figura 6.18 foi construído através da equação (5.2). 
Capítulo 6 - Ensaios de Laboratório e Resultados

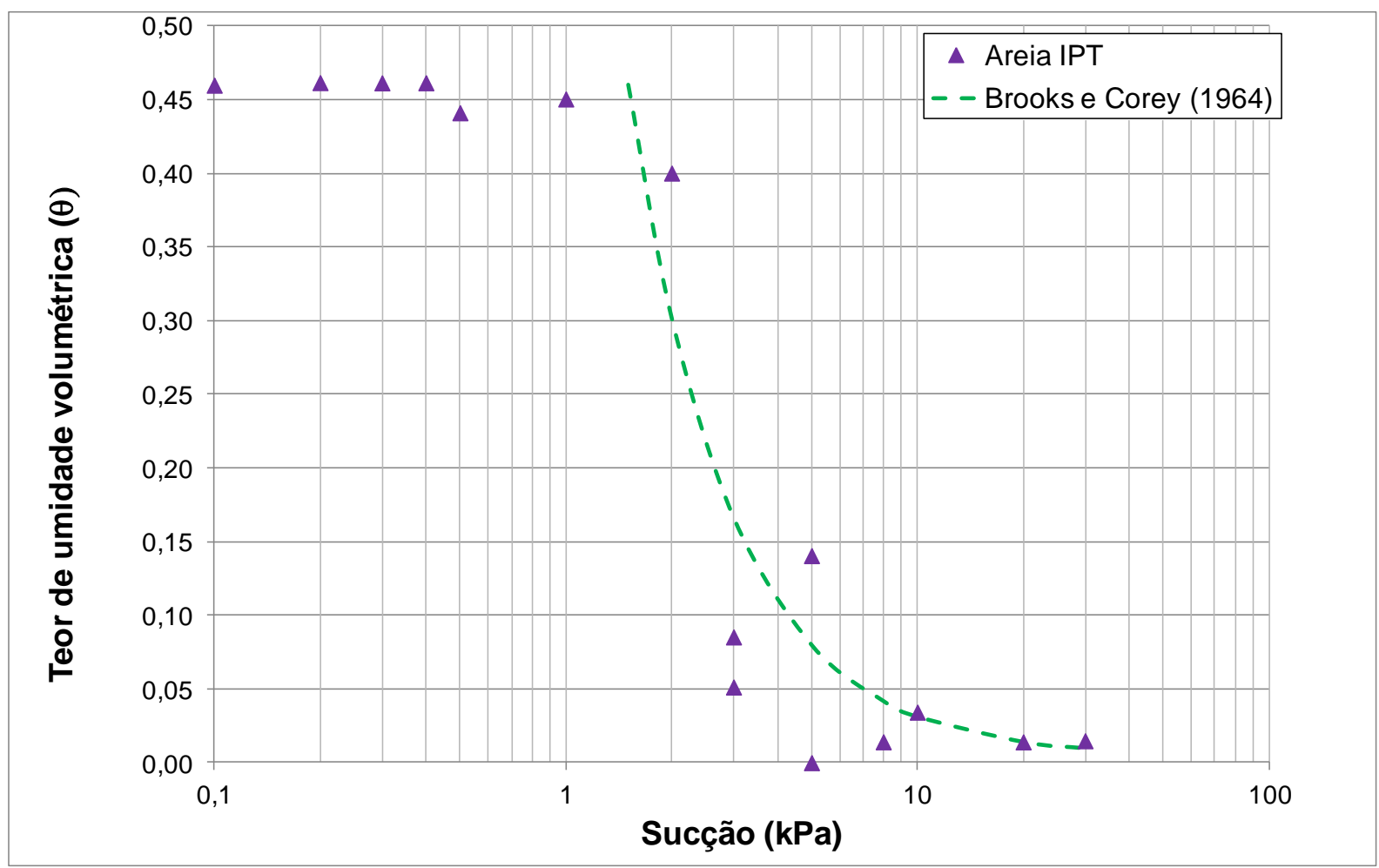

Figura 6.18 - Curva de retenção de água da Areia do IPT e o ajuste do modelo de Brooks e Corey.

Devido à uniformidade da Areia do IPT não foi possível aplicar o modelo utilizado pelo programa Splintex.

Para os ensaios de permeabilidade ao ar os índices de vazios dos corpos de prova utilizados foram de aproximadamente 0,86. Assim como para a Areia Osasco foram feitos ensaios com vários graus de saturação à água para analisar a variação da permeabilidade ao ar com o grau de saturação do solo. Os ensaios também foram realizados com uma confinante de $50 \mathrm{kPa}$, e com pressões de entrada de 3, 4, 5, 7, 9, 10, 20, 30 e $40 \mathrm{kPa}$; variando as saturações de água das amostras, as saturações utilizadas foram 0, 20 e 50\%. Na saturação de $50 \%$ com pressões acima de $10 \mathrm{kPa}$ o ensaio não conseguiu ser realizado, pois no local de saída de ar da amostra para o aparelho que realiza a leitura notou-se que junto com o ar também saía água, e por esse motivo o ensaio foi interrompido.

Na Figura 6.19 pode ser observada a variação da permeabilidade ao ar com a saturação da amostra. 
Capítulo 6 - Ensaios de Laboratório e Resultados

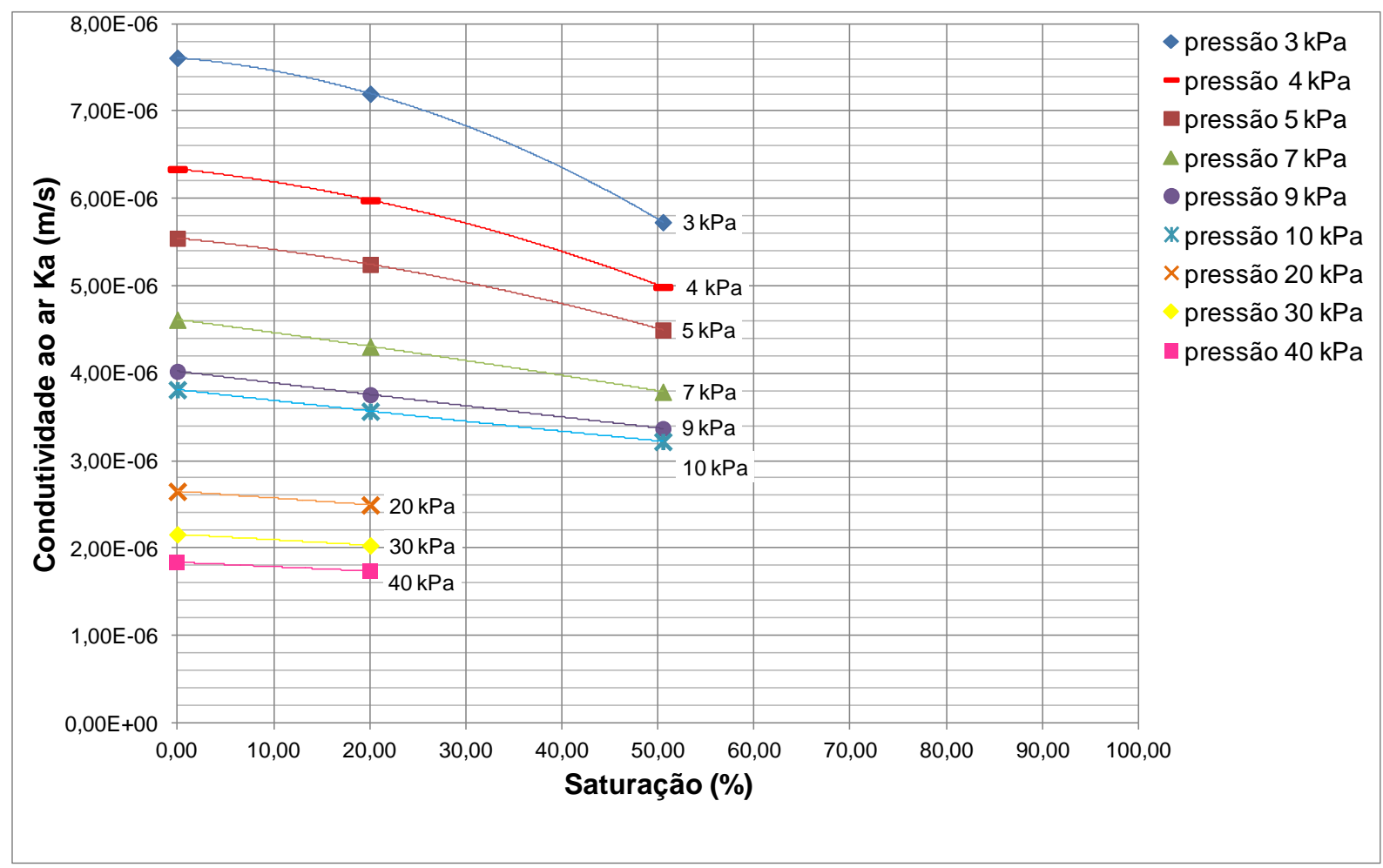

Figura 6.19 - Gráfico mostrando a variação da Condutividade ao ar com a saturação de água para a Areia do IPT.

Na Areia do IPT nota-se uma queda mais rápida na curva de condutividade ao ar em relação à saturação devido à menor capacidade de retenção do solo em comparação com a Areia Osasco.

A Figura 6.20 mostra a relação entre a permeabilidade intrínseca e o inverso da pressão média para as saturações em que os ensaios foram realizados; desse gráfico foram obtidos os valores aproximados do $k_{\text {int }}$ que foi de $2,4 \times 10^{-12} \mathrm{~m}^{2}$ e $b$ que foi de $2,88 \mathrm{kPa}$. 


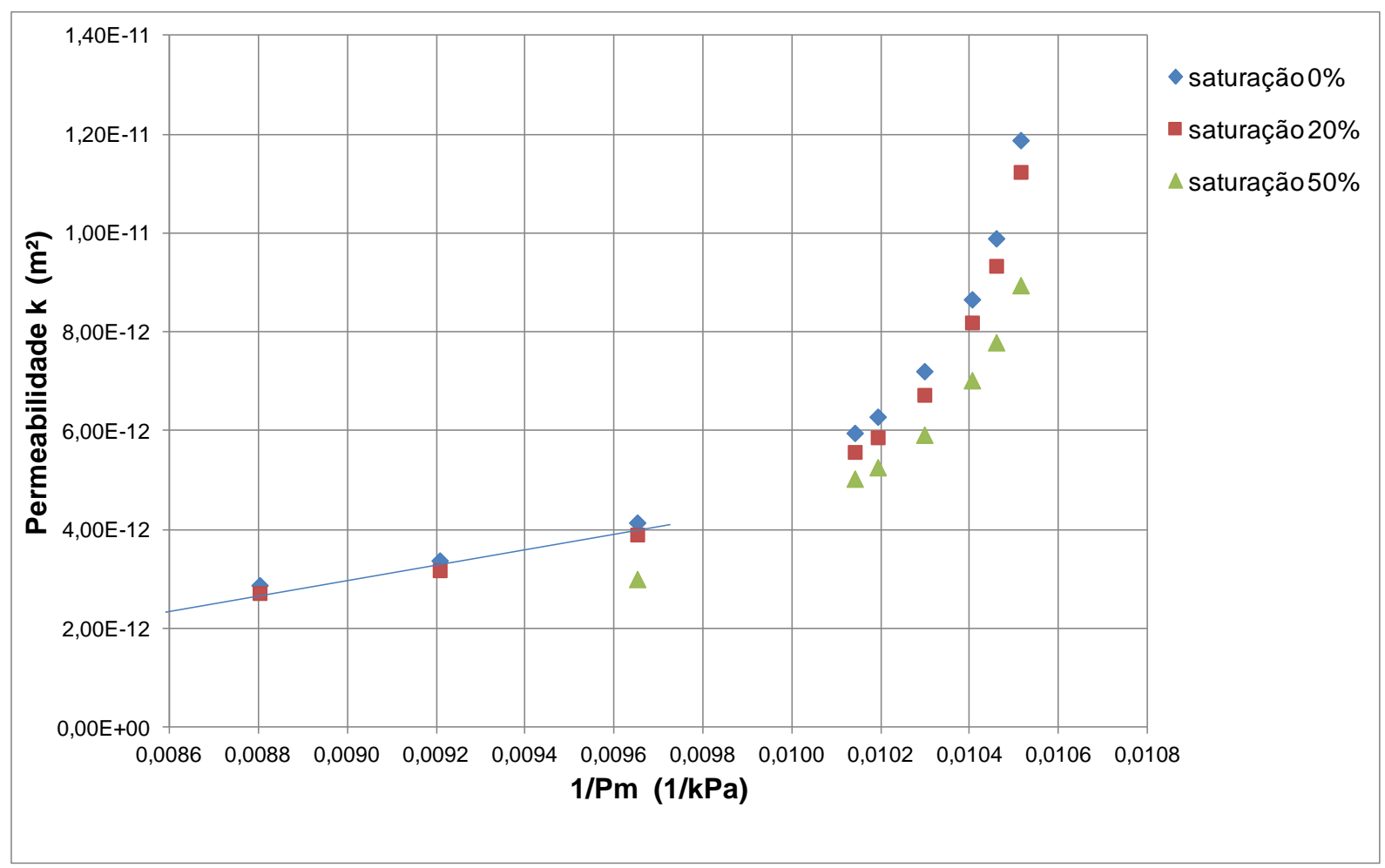

Figura 6.20 - Gráfico da permeabilidade intrínseca versus o inverso da pressão média, para a Areia do IPT.

Assim como para o Areia Osasco os ensaios de permeabilidade a água da Areia do IPT foram feitos segundo a norma NBR-13292, com o índice de vazios máximo, mínimo e com o índice de vazios equivalente a compacidade relativa de $70 \%$. A Tabela 6.7 mostra os resultados dos ensaios de condutividade a água realizados para a Areia do IPT.

Tabela 6.7 - Condutividade a água encontrada para cada índice de vazios.

\begin{tabular}{cccc}
\hline \multicolumn{2}{c}{ Índice de vazios } & $\mathbf{K}(\mathbf{m} / \mathbf{s}) \mathbf{2 4}^{\circ}$ & $\mathbf{K}(\mathbf{m} / \mathbf{s}) \mathbf{2 0}^{\circ}$ \\
\hline e $_{\text {máximo }}$ & 0,97 & $2,4 \times 10^{-3}$ & $2,2 \times 10^{-3}$ \\
$\mathrm{E}$ & 0,86 & $1,9 \times 10^{-3}$ & $1,7 \times 10^{-3}$ \\
$\mathrm{e}_{\text {mínimo }}$ & 0,81 & $1,7 \times 10^{-3}$ & $1,5 \times 10^{-3}$ \\
\hline
\end{tabular}

Na Figura 6.21 pode ser visto o gráfico de Condutividade à água versus índice de vazios. 


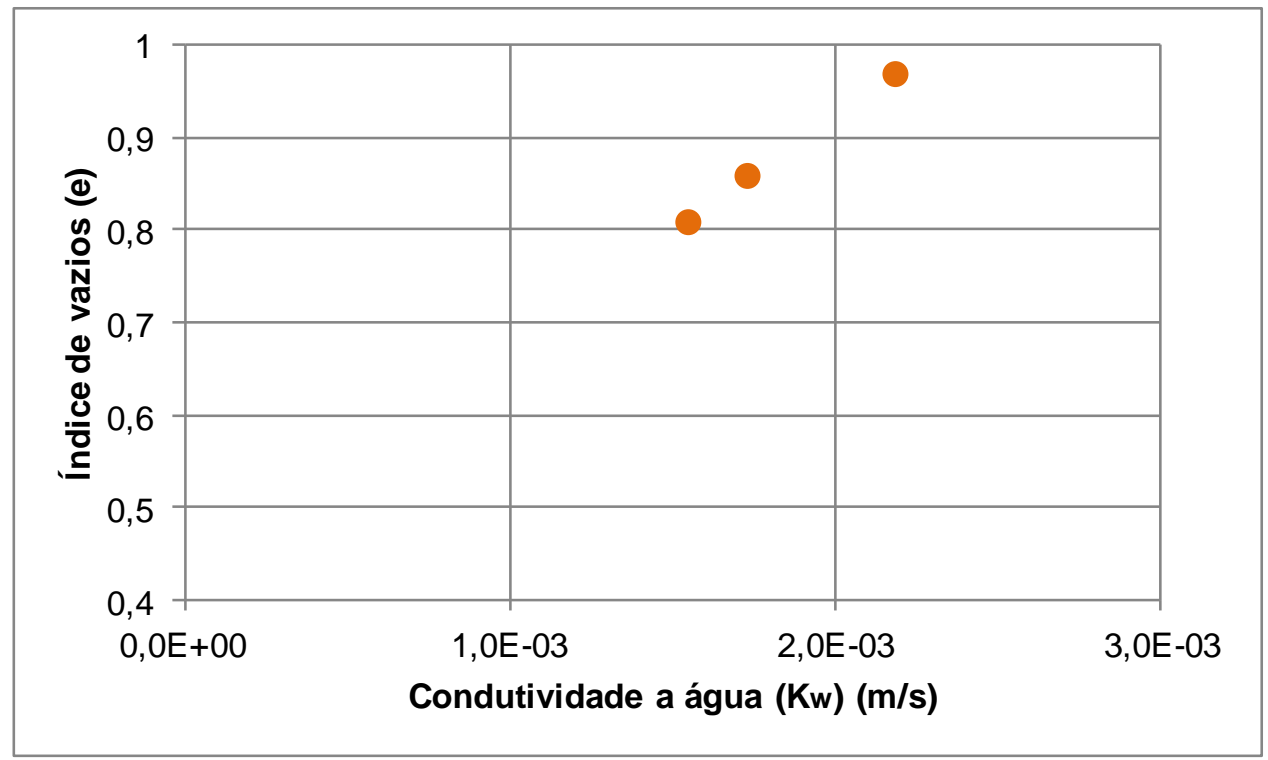

Figura 6.21 - Gráfico da Condutividade a água pelo índice de vazios, Areia do IPT.

\subsection{Resultados dos ensaios com as lentes de baixa permeabilidade}

Segundo Oliveira, 2004 o solo utilizado, nas lentes de baixa permeabilidade, é proveniente de um talude de solo residual de gnaisse, composto principalmente por areia siltosa micácea com núcleos de caulim derivados de feldspato e por pequenos veios de quartzo.

Os ensaios realizados para as lentes de baixa permeabilidade foram feitos com material passado na peneira \#40, assim como o solo usado nas lentes do modelo físico bidimensional.

A Figura 6.22 apresenta a curva granulométrica do solo que é composto por $46 \%$ de silte, $34 \%$ de areia e $20 \%$ de argila, sendo por isso classificado como um silte arenoargiloso. 
Capítulo 6 - Ensaios de Laboratório e Resultados

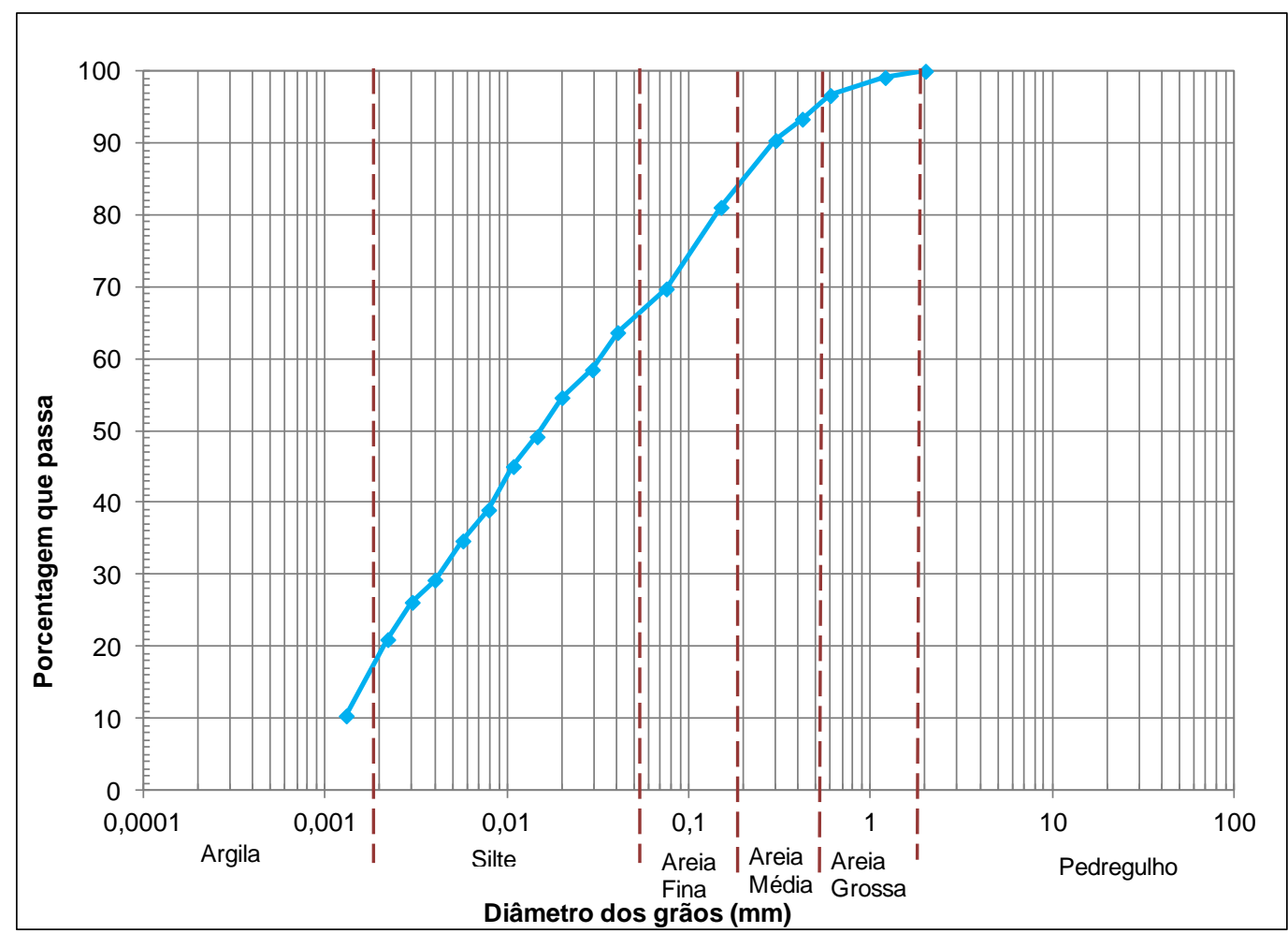

Figura 6.22 - Curva granulométrica do solo residual de gnaisse (dados obtidos de Oliveira, 2004).

De acordo com os resultados de caracterização realizados por Oliveira, 2004; o limite de liquidez é de $47 \%$, o limite de plasticidade é de $34 \%$ e a densidade dos grãos é de $2,71 \mathrm{~g} / \mathrm{cm}^{3}$.

O processo de moldagem dos corpos de prova do ensaio de curva de retenção pode ser encontrado em Oliveira (2004). A Figura 6.23 apresenta a curva de retenção de água das lentes de baixa permeabilidade em termos de saturação de água. 
Capítulo 6 - Ensaios de Laboratório e Resultados

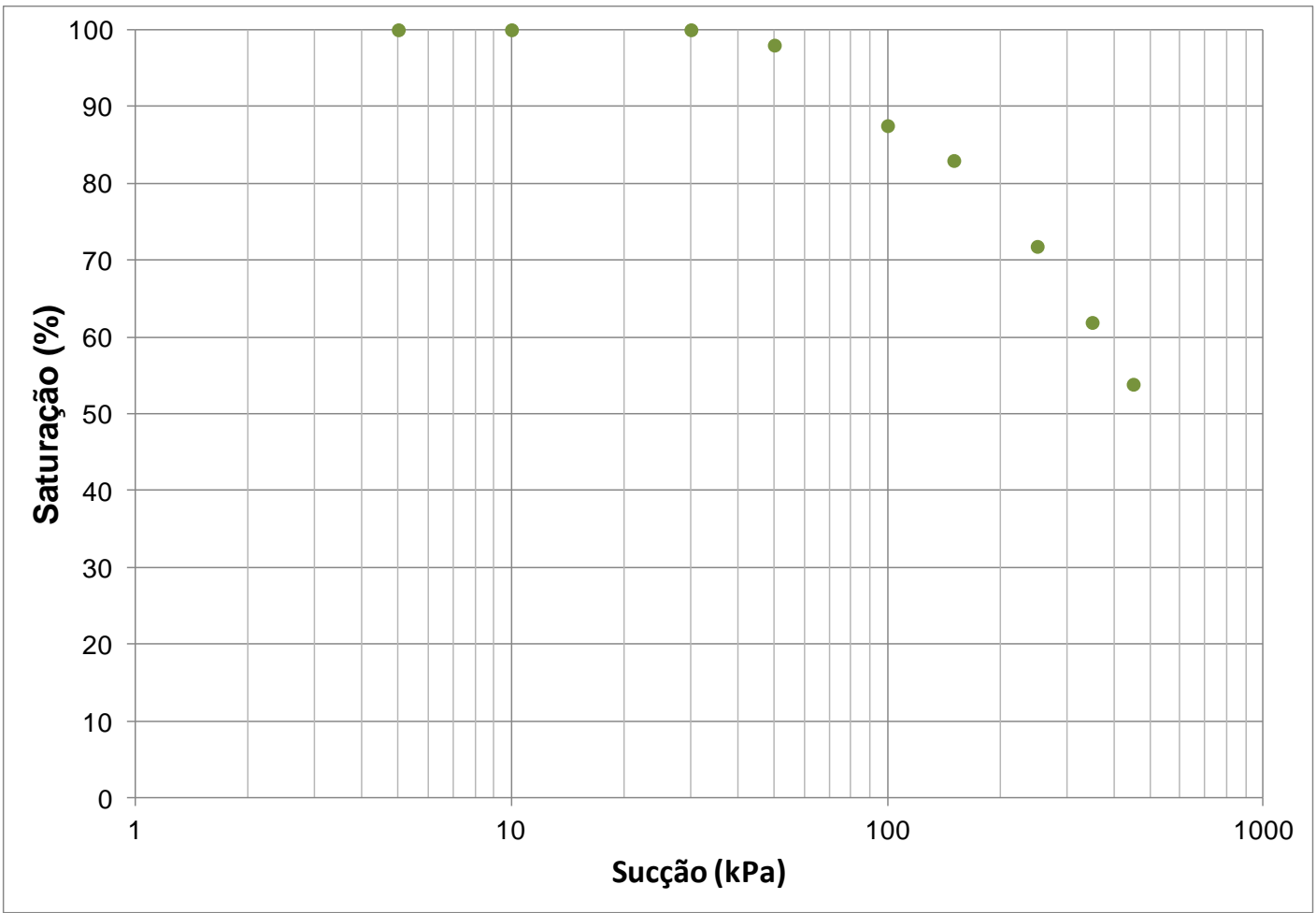

Figura 6.23 - Curva de retenção de água das lentes de baixa permeabilidade em termos de teor de umidade volumétrica (dados obtidos de Oliveira, 2004).

Já a Figura 6.24 mostra a curva de retenção de água em termos de teor de umidade volumétrica.

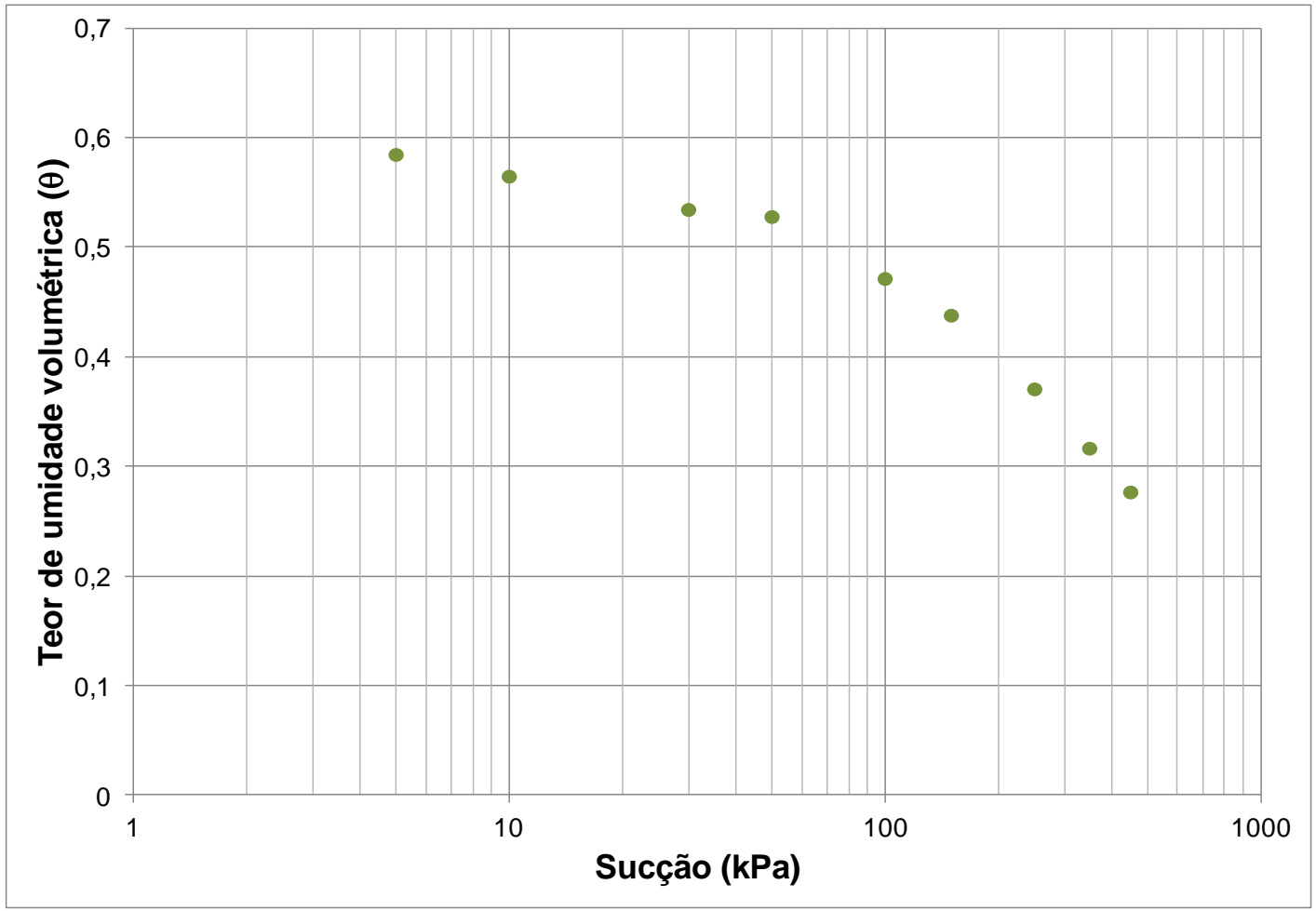

Figura 6.24 - Curva de retenção de água das lentes de baixa permeabilidade em termos de teor de umidade volumétrica (dados obtidos de Oliveira, 2004). 
Para os lentes de baixa permeabilidade os parâmetros encontrados através do modelo de Van Genuchten foram a pressão de entrada de ar $\left(\psi_{\mathrm{b}}\right)$ é de $50 \mathrm{kPa}$ $(\alpha=0,02)$, a distribuição dos poros ( $n)$ é 2,37 , a simetria global da curva $(m)$ é 0,11 e o teor de umidade volumétrica equivalente a saturação completa $(\theta s)$ é 0,58 . A Figura 6.25 apresenta a curva de retenção encontrada em laboratório e a curva ajustada pelo método de Van Genuchten (1980).

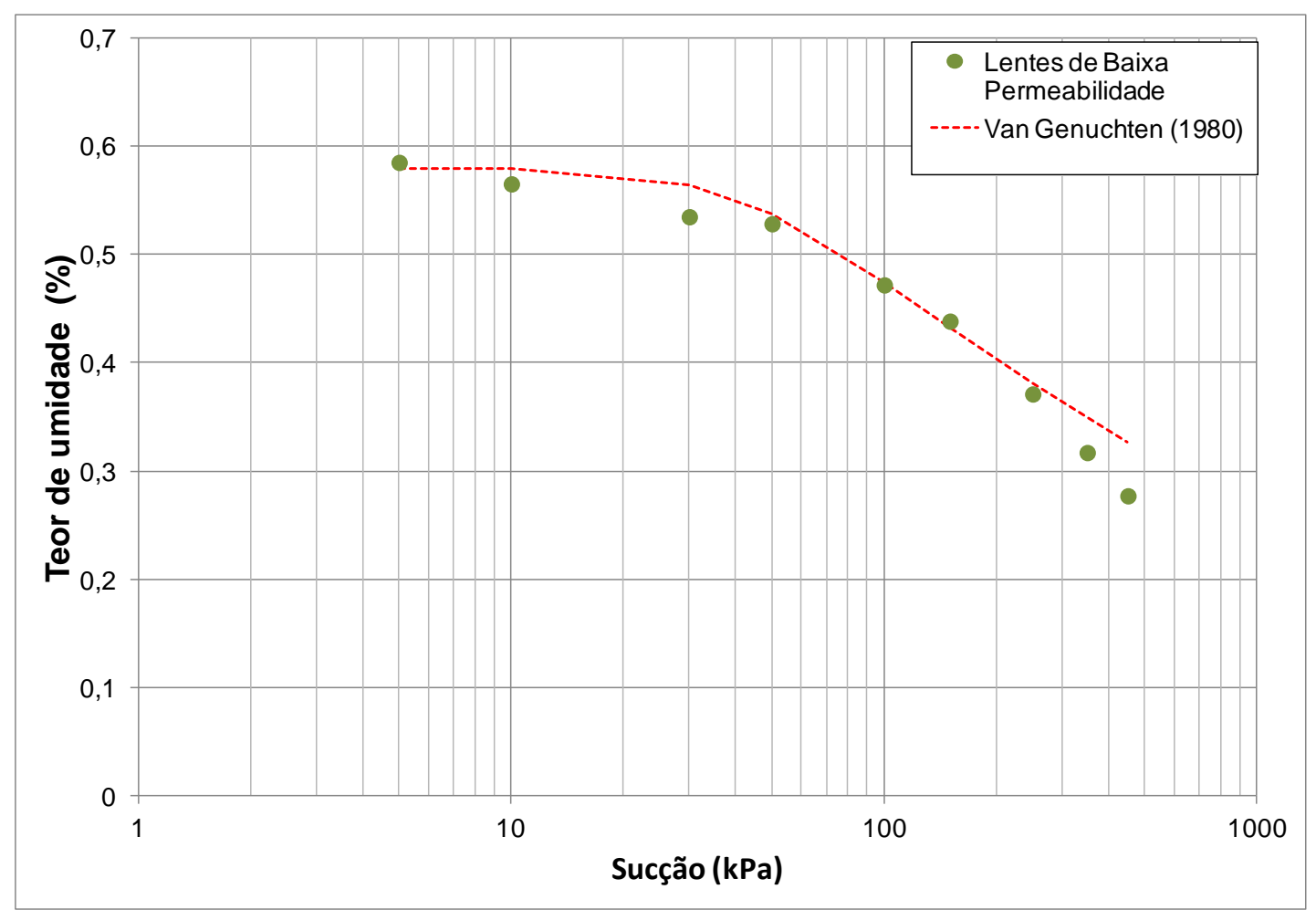

Figura 6.25 - Curva de retenção de água das lentes de baixa permeabilidade e o ajuste feito pelo modelo de Van Genuchten (1980). 


\section{Capítulo 7}

\section{Ensaios com o Modelo Físico Bidimensional em Laboratório}

Para a realização dos ensaios bidimensionais em laboratório foi utilizado um tanque fino e transparente feito de placas de acrílico, para uma melhor visualização dos caminhos de ar formados durante a injeção. Foram utilizadas duas areias de granulometrias diferentes, uma denominada de Areia Osasco e outra de Areia do IPT. Como já foi visto anteriormente a Areia Osasco é uma areia natural e a Areia do IPT de uma areia comercial uniforme. Também foram feito ensaios com a Areia do IPT associadas a lentes de baixa permeabilidade, essas lentes foram feitas com o solo residual apresentado anteriormente.

\subsection{Descrição do tanque}

As placas de acrílico utilizadas no tanque têm uma espessura de $2,5 \mathrm{~cm}$, e as dimensões internas do tanque são $90 \mathrm{~cm}$ de altura, $110 \mathrm{~cm}$ de comprimento e $3 \mathrm{~cm}$ de largura; assim como as do modelo bidimensional utilizado por Baker e Benson (2007). As paredes do tanque, além de terem sido coladas, foram fixadas usando parafusos de aço inox; foram instalados 6 parafusos em cada lateral e 8 na base com um espaçamento de $15 \mathrm{~cm}$ entre cada parafuso; o tanque e suas dimensões podem ser vistas na Figura 7.1. Foi construído um suporte para o manuseio e transporte do tanque, esse suporte possui quatros rodas para a movimentação do mesmo caso necessário, também foi instalado um sistema que permite a rotação do tanque para sua limpeza interna. Tanto as rodas como o sistema de rotação possuem travas para que o tanque permaneça fixo durante os ensaios; esse suporte também pode ser observado na Figura 7.1. 


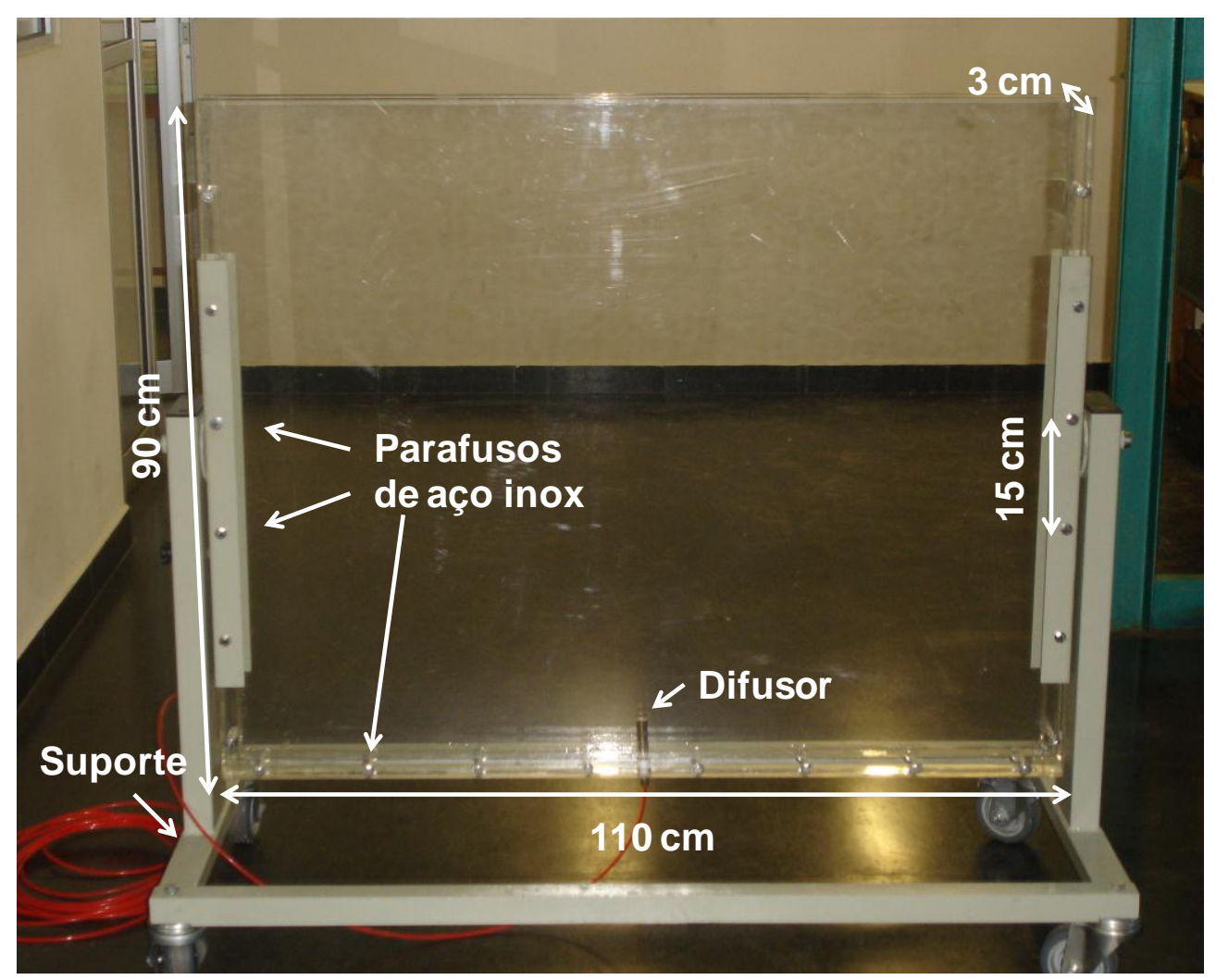

Figura 7.1 - Dimensões do modelo físico bidimensional utilizado nos ensaios de injeção de ar.

No centro da base do tanque foi feito um furo rosqueado para a instalação do difusor. As etapas da montagem do difusor podem ser vistas na Figura 7.2. Primeiro foi feito um furo com broca (a), seguido da execução da rosca (b) que foi feita com uma rosca macho, e por último foi feita a instalação do difusor. Na Figura 7.2-(c) pode ser visto o detalhe do furo rosqueado. Para evitar vazamentos pelo difusor o mesmo foi instalado junto com fita de teflon (fita veda rosca). 
Capítulo 7 - Ensaios com o Modelo Físico Bidimensional em Laboratório
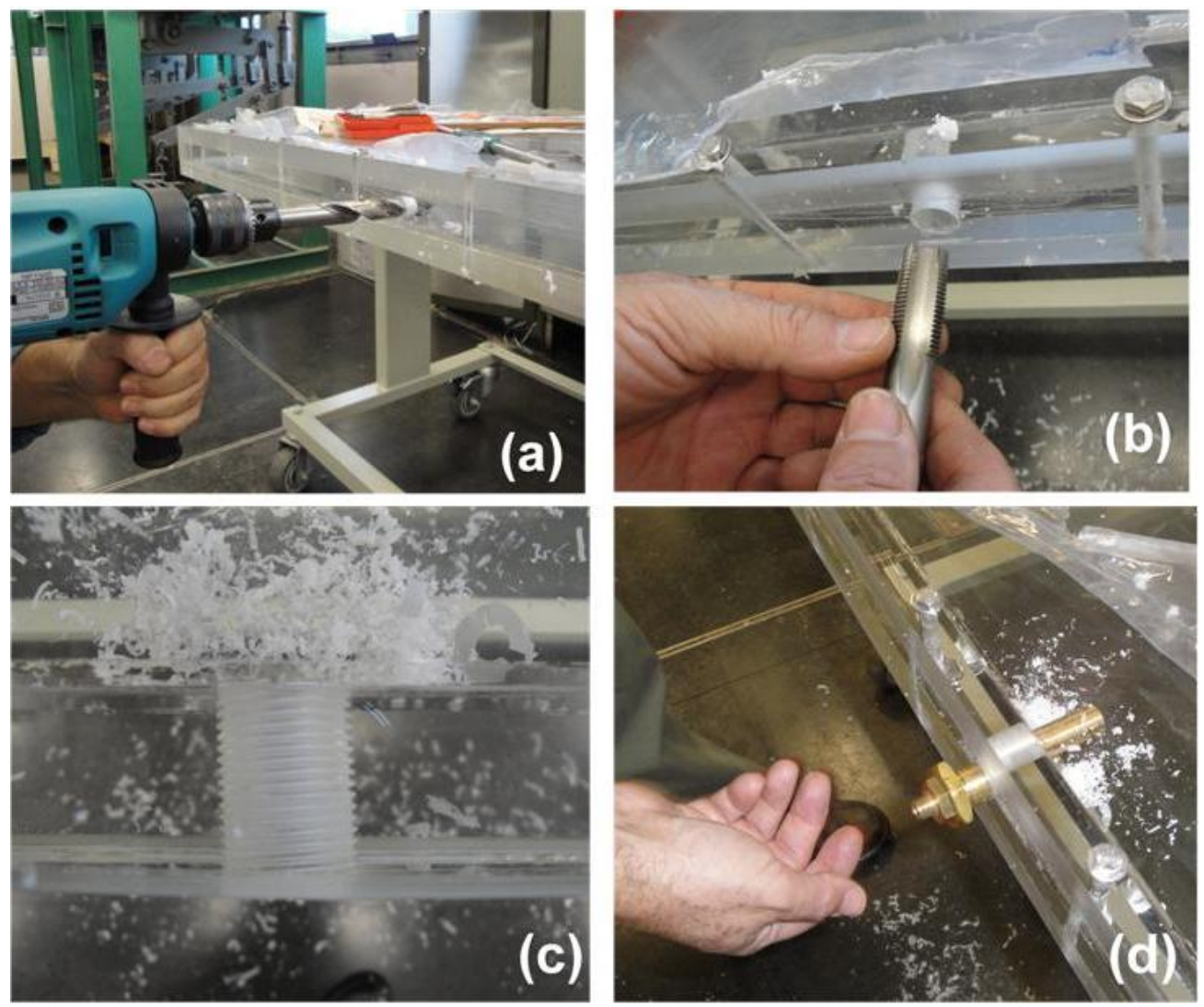

Figura 7.2 - Instalação do difusor

A injeção de ar foi feita através do difusor, que foi feito de latão e em três partes rosqueadas como pode ser observado na Figura 7.3. A vedação das roscas das partes do difusor também foi feita com fita de teflon (veda rosca).

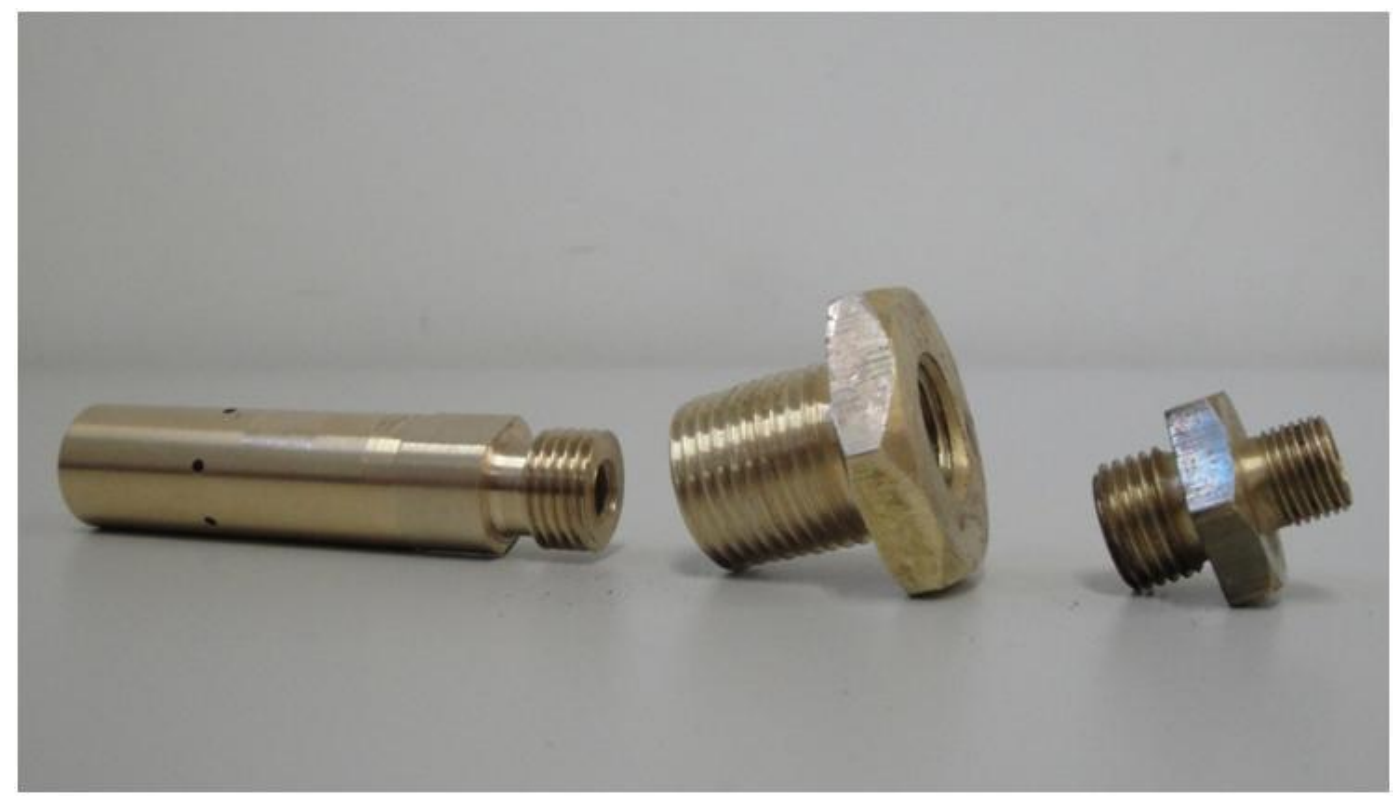

Figura 7.3 - Partes do difusor usado na injeção de ar 
O difusor possui $3 \mathrm{~cm}$ de altura e 1,5 cm de diâmetro, foram feitos 6 furos de saída de ar, distribuídos simetricamente pelo difusor, que estão localizados a $1 \mathrm{~cm}$ do topo, sendo que cada furo tem $1,5 \mathrm{~mm}$ de diâmetro. A Figura 7.4 apresenta o difusor montado e o detalhe dos furos de saída de ar.

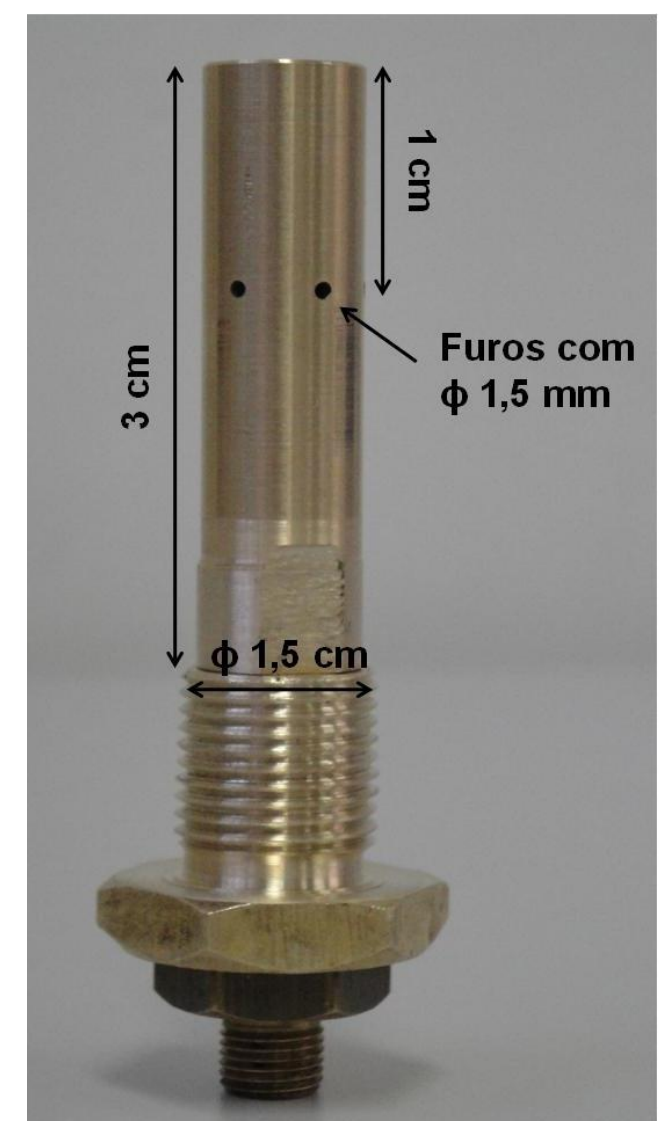

Figura 7.4 - Difusor montado, seus furos e suas dimensões.

Após a conclusão da instalação do difusor, o tanque foi preenchido com água para se certificar que não haveria vazamentos durante os ensaios, em seguida foi injetado ar para a verificação do difusor. Na Figura 7.5 pode ser visto o detalhe de como o difusor foi conectado ao compressor de ar. 


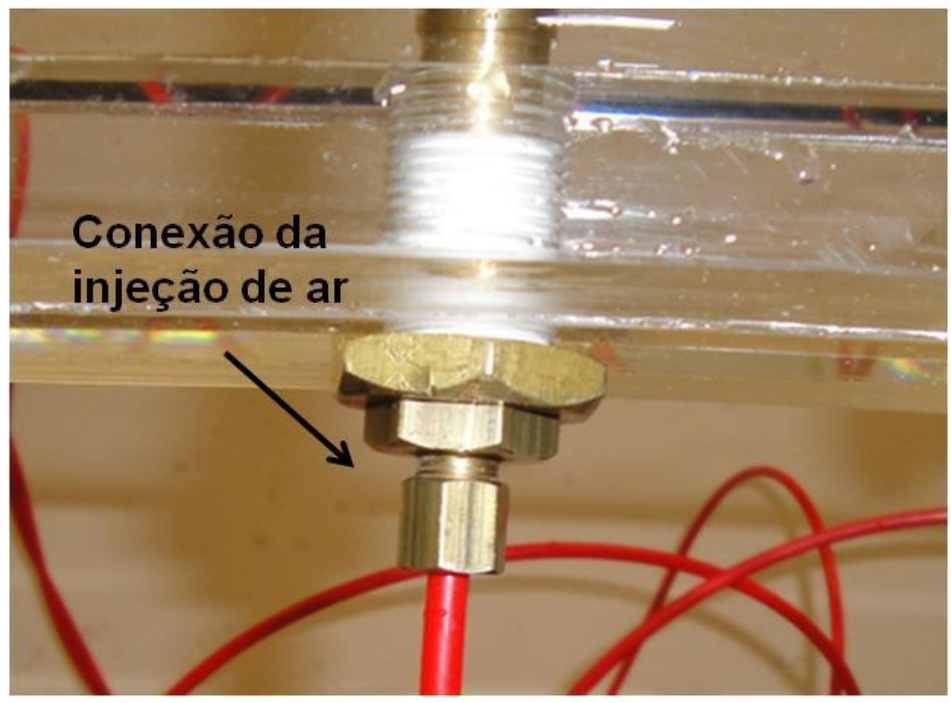

Figura 7.5 - Detalhe da conexão da injeção de ar com o difusor

\subsection{Limpeza do tanque}

A limpeza do tanque foi realizada quando houve troca de material, como por exemplo, quando os quatro primeiros ensaios com a Areia Osasco foram concluídos e seriam feitos ensaios com a Areia do IPT. Primeiramente foram colocadas bandejas em baixo do tanque para a coleta e reaproveitamento do material utilizado, depois o tanque foi rotacionado como pode ser notado na Figura 7.6-(a). Com a abertura do tanque para baixo foi injetado água pelo difusor e com o auxilio de um martelo de borracha foram efetuadas pequenas batidas nas laterais do tanque, ver Figura 7.6-(b) e (c). Com isso o solo foi aos poucos caindo do tanque como mostra a Figura 7.6-(d). 
Capítulo 7 - Ensaios com o Modelo Físico Bidimensional em Laboratório
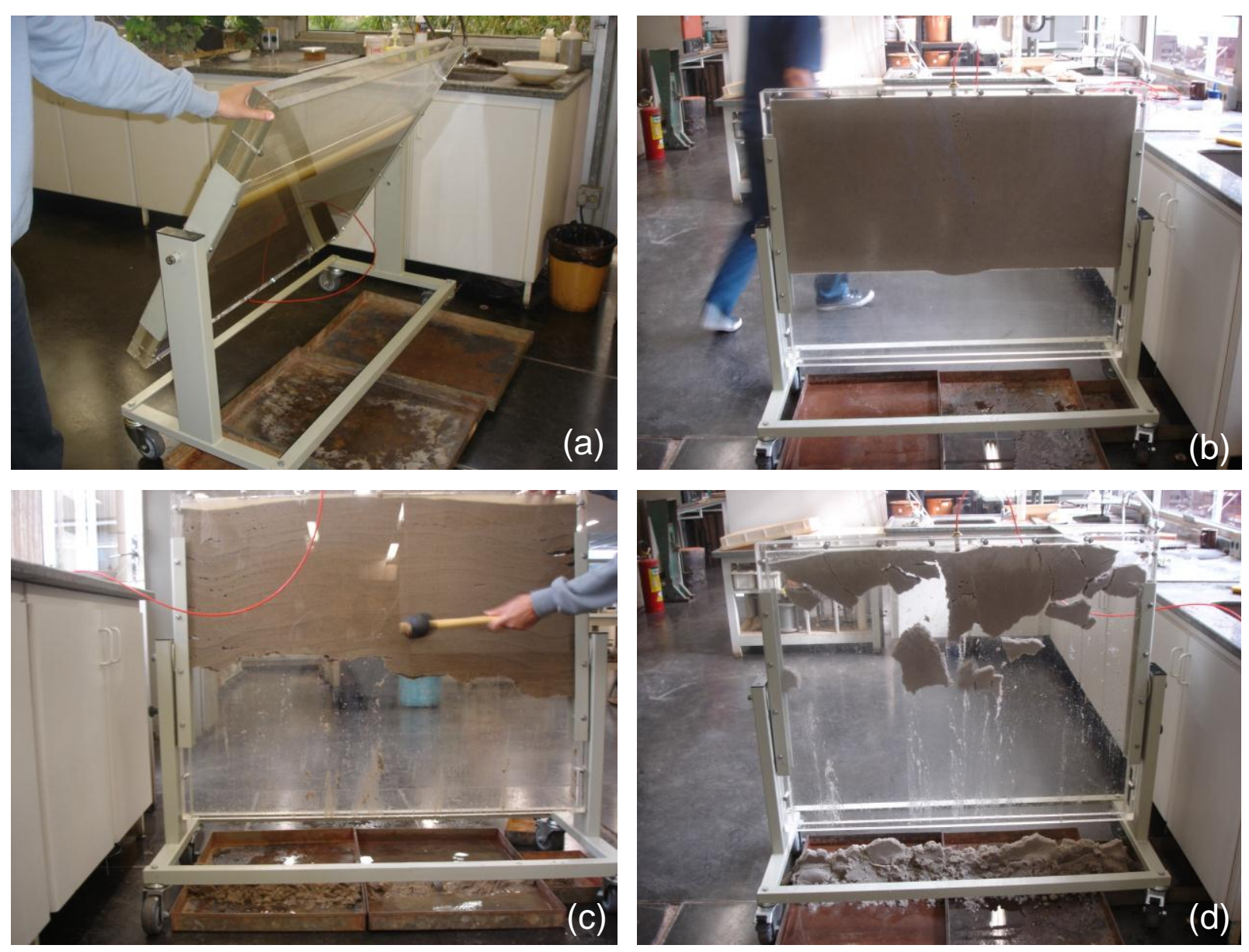

Figura 7.6 - Fotos da limpeza do tanque após a término dos ensaios.

\subsection{Ensaios com o modelo físico bidimensional (tanque)}

\subsubsection{Areia Osasco}

Foram realizados cinco ensaios com a Areia Osasco no modelo físico, cada um com um arranjo diferente de solo causando uma mudança no comportamento de fluxo como pode ser observado na Tabela 7.1. 
Capítulo 7 - Ensaios com o Modelo Físico Bidimensional em Laboratório

Tabela 7.1 - Descrição dos ensaios realizados com a Areia Osasco no modelo físico.

\begin{tabular}{|c|c|c|}
\hline Ensaio & Característica do Solo & Comportamento do Fluxo \\
\hline 1 & $\begin{array}{l}\text { Solo depositado no } \\
\text { tanque por sedimentação } \\
\text { (sem controle da vazão e } \\
\text { pressão de injeção) }\end{array}$ & $\begin{array}{l}\text { Devido à alta pressão de injeção de ar inicial } \\
\text { houve a ruptura do solo. Movimento lateral } \\
\text { acentuado, e bolhas de ar presas nas lentes } \\
\text { de menor permeabilidade. }\end{array}$ \\
\hline 2 & 1ㄹ Homogeneização & $\begin{array}{l}\text { Zona de influência não simétrica, movimento } \\
\text { preferencial pelo lado esquerdo do tanque. }\end{array}$ \\
\hline 3 & 2ª Homogeneização & $\begin{array}{l}\text { Zona de influência não simétrica, movimento } \\
\text { preferencial pelo lado esquerdo do tanque. }\end{array}$ \\
\hline 4 & 3ㅁ Homogeneização & $\begin{array}{l}\text { Zona de influência não simétrica, movimento } \\
\text { preferencial pelo lado direito do tanque. }\end{array}$ \\
\hline 5 & $\begin{array}{l}\text { Solo depositado no } \\
\text { tanque por sedimentação } \\
\text { (com controle da vazão e } \\
\text { pressão de injeção) }\end{array}$ & $\begin{array}{l}\text { Zona de influência simétrica, movimento lateral } \\
\text { acentuado. }\end{array}$ \\
\hline
\end{tabular}

Nos ensaios com o modelo físico bidimensional a areia foi colocada através de um funil feito com garrafa PET como se pode notar na Figura 7.7-(a), nessa mesma figura pode ser vista a sedimentação da areia. A água foi adicionada ao tanque antes da areia, para que fosse garantida a saturação completa do solo e criado um processo de sedimentação da mesma, sendo assim formaram-se várias camadas com parte fina da areia sobre a parte grossa; na Figura 7.7-(b) podem ser vistas essas camadas. 

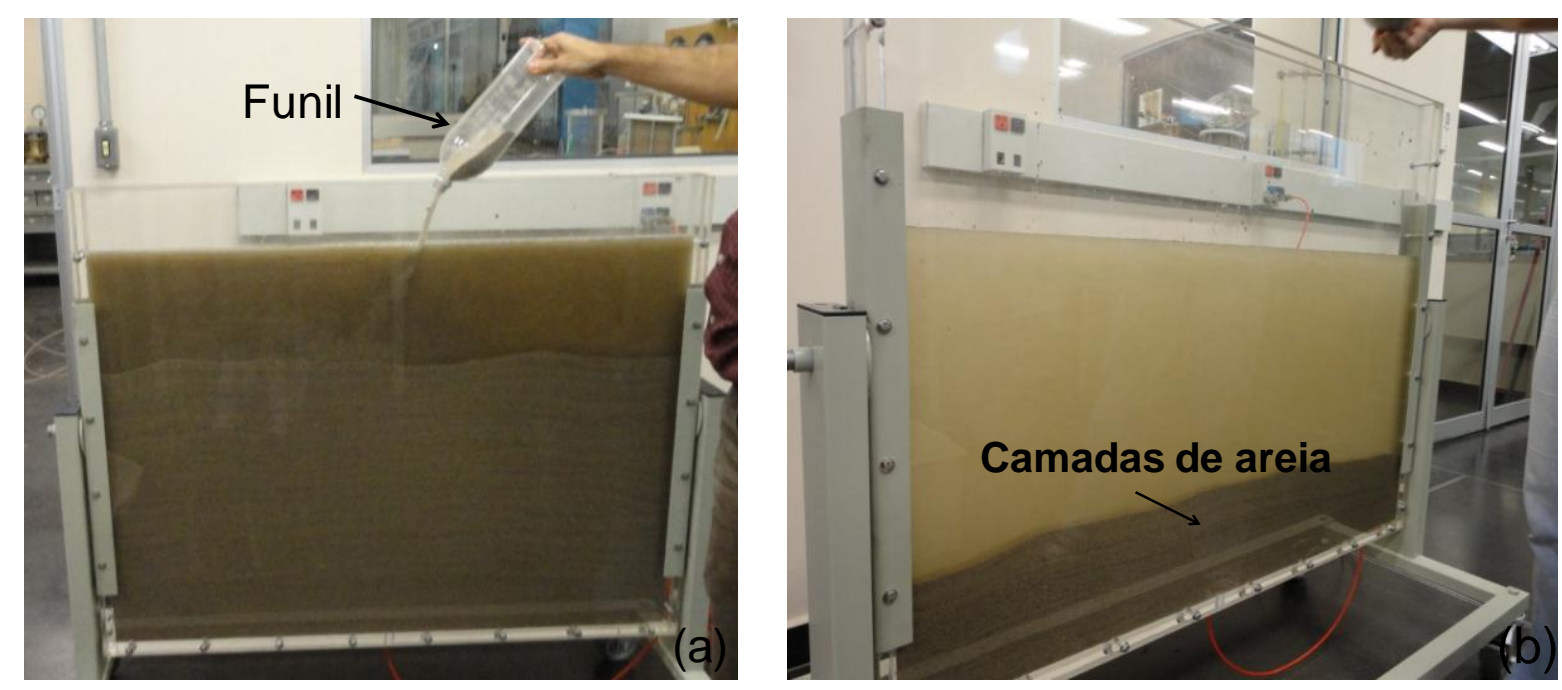

Figura 7.7 - Primeiro ensaio realizado com o tanque, em (a) a areia sendo colocada no tanque e em (b) as camadas da areia após a sedimentação.

Foram colocados $34,5 \mathrm{~kg}$ da Areia Osasco que atingiu uma altura aproximada de 65 $\mathrm{cm}$ no tanque. Como o volume interno do tanque é conhecido, o índice de vazios e a porosidade foram calculados obtendo-se os seguintes resultados 0,65 e 0,39 , respectivamente. $O$ nível d'água ficou $5 \mathrm{~cm}$ acima da superfície do solo.

Neste ensaio a pressão de injeção não foi medida e nem controlada, mas pode-se notar que as camadas de areia sedimentada interferiram no teste assim como foi descrito em ensaios realizados por Ji et al., (1993) e outros; pois quando o ar encontra uma camada menos permeável acima ele acaba migrando lateralmente pela camada mais permeável como na Figura 7.8.

Pode ser observado na Figura 7.8 e em detalhe na Figura 7.9 uma bolha de ar que ficou aprisionada no solo devido às camadas de areia mais fina impedirem a passagem do ar verticalmente. O movimento lateral pode ser percebido pelas bolhas de ar nos cantos superiores do modelo físico. 


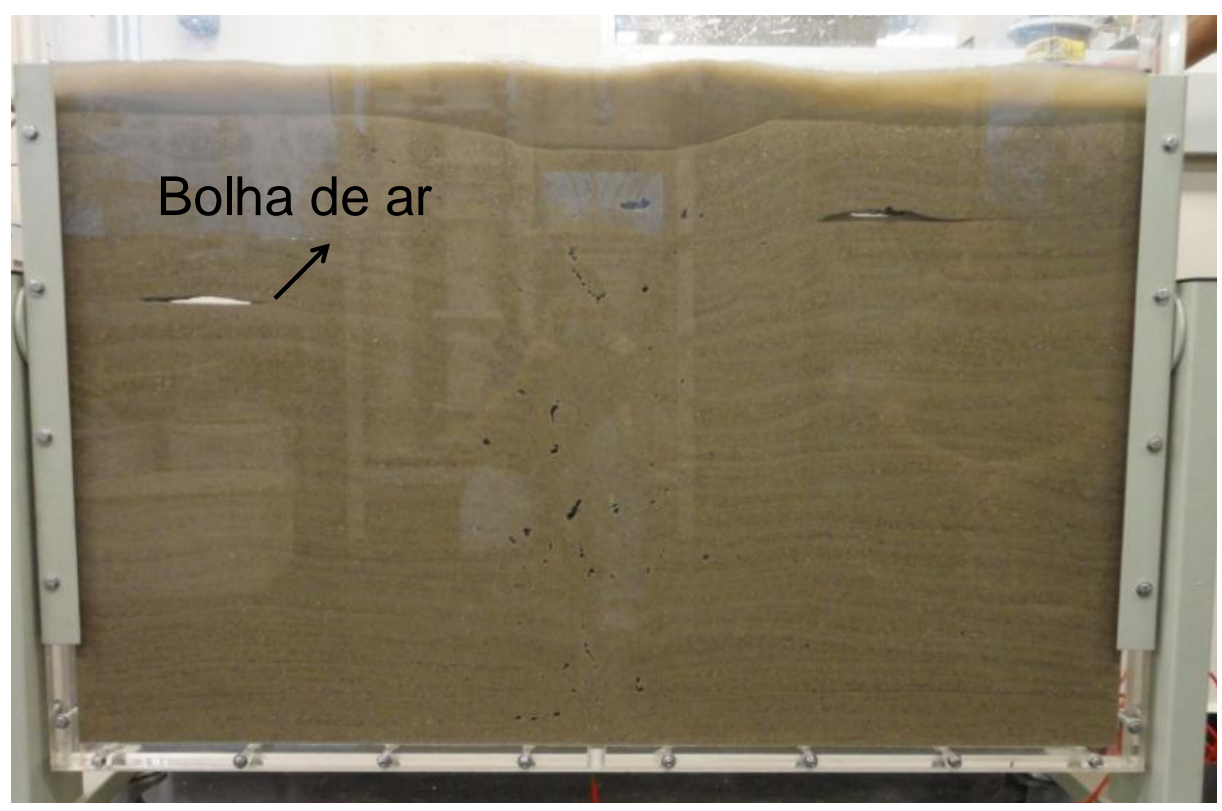

Figura 7.8 - Caminhos formados durante a injeção de ar no primeiro ensaio, Areia Osasco.

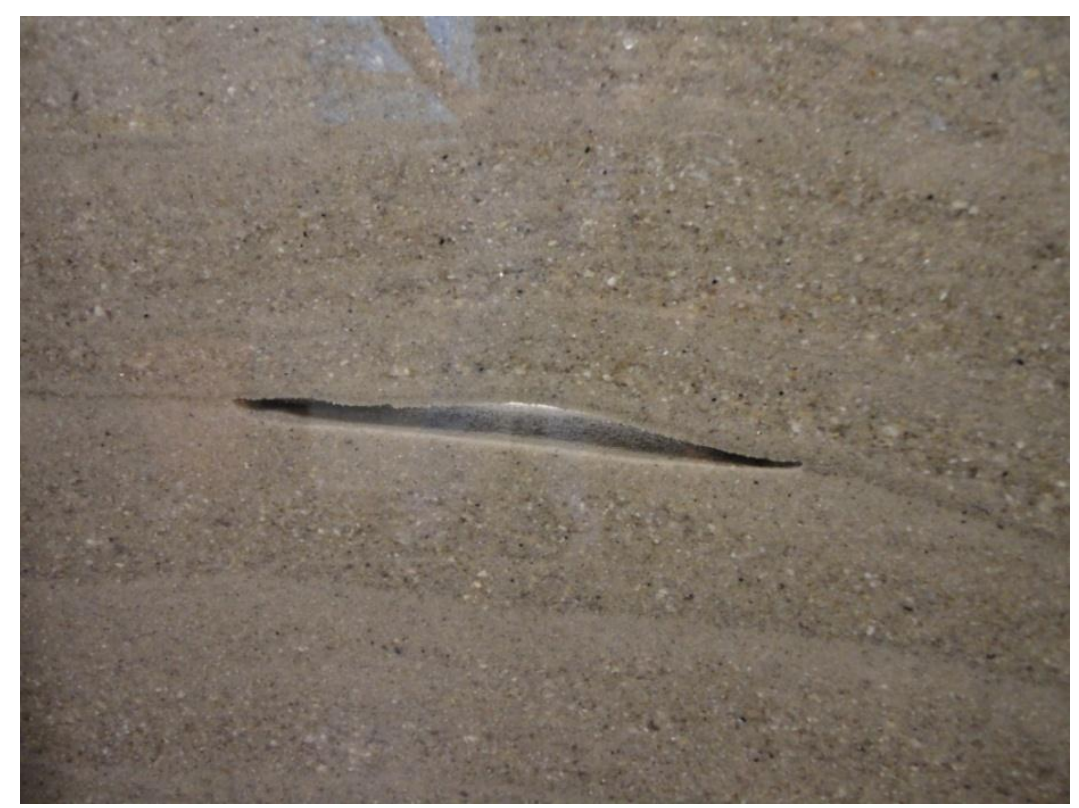

Figura 7.9 - Detalhe da bolha de ar aprisionada durante o ensaio.

\subsubsection{Homogeneização da Areia no Tanque}

A homogeneização da areia no tanque foi feita através de um tubo de PVC com uma pedra porosa na ponta, conforme pode ser observado na Figura 7.10-(a). A cravação do tubo foi feita através da injeção de água para facilitar a entrada do mesmo no solo. Isto foi realizado por toda a extensão do tanque fazendo com que a areia fosse 
homogeneizada; ver Figura 7.10-(b), (c), (d) e (e); o excesso de água foi retirado do tanque através de outro tubo mais fino o que pode ser observado na Figura 7.10-(f).
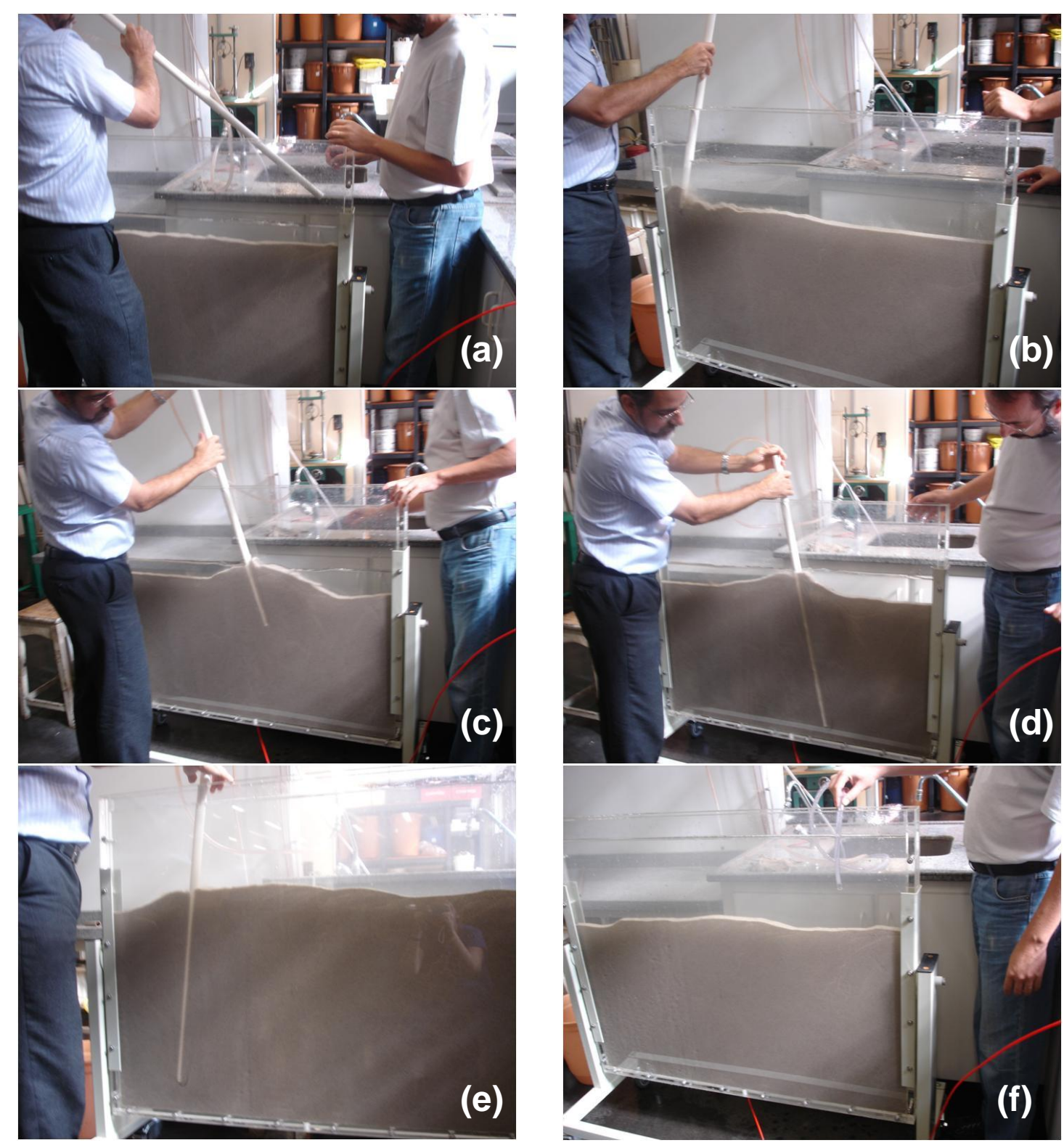

Figura 7.10 - Fotos da homogeneização da areia no tanque.

Depois de realizados os ensaios com a Areia Osasco no modelo físico a areia foi retirada e realizou-se novamente o ensaio de granulometria para verificar se houve perda de material durante o processo de homogeneização. Na Tabela 7.2 pode ser visto o resultado do ensaio e na Figura 7.11 tem-se a curva granulométrica correspondente. 
Capítulo 7 - Ensaios com o Modelo Físico Bidimensional em Laboratório

Tabela 7.2 - Dados da curva granulométrica da Areia Osasco depois dos ensaios com o tanque.

\begin{tabular}{cc}
\hline Porcentagem que passa & Diâmetro dos grãos $(\mathbf{m m})$ \\
\hline 100 & 4,80 \\
99,15 & 2,00 \\
92,28 & 1,20 \\
66,41 & 0,60 \\
42,84 & 0,42 \\
26,12 & 0,30 \\
4,66 & 0,15 \\
0,20 & 0,075 \\
\hline
\end{tabular}

A Figura 7.11 apresenta em um mesmo gráfico as curvas granulométricas da Areia Osasco antes e depois dos ensaios realizados com o tanque. A comparação entre as curvas mostrou que não houve diferença entre as granulometrias da areia significando que não ocorreu nenhuma perda de material durante o processo de homogeneização.

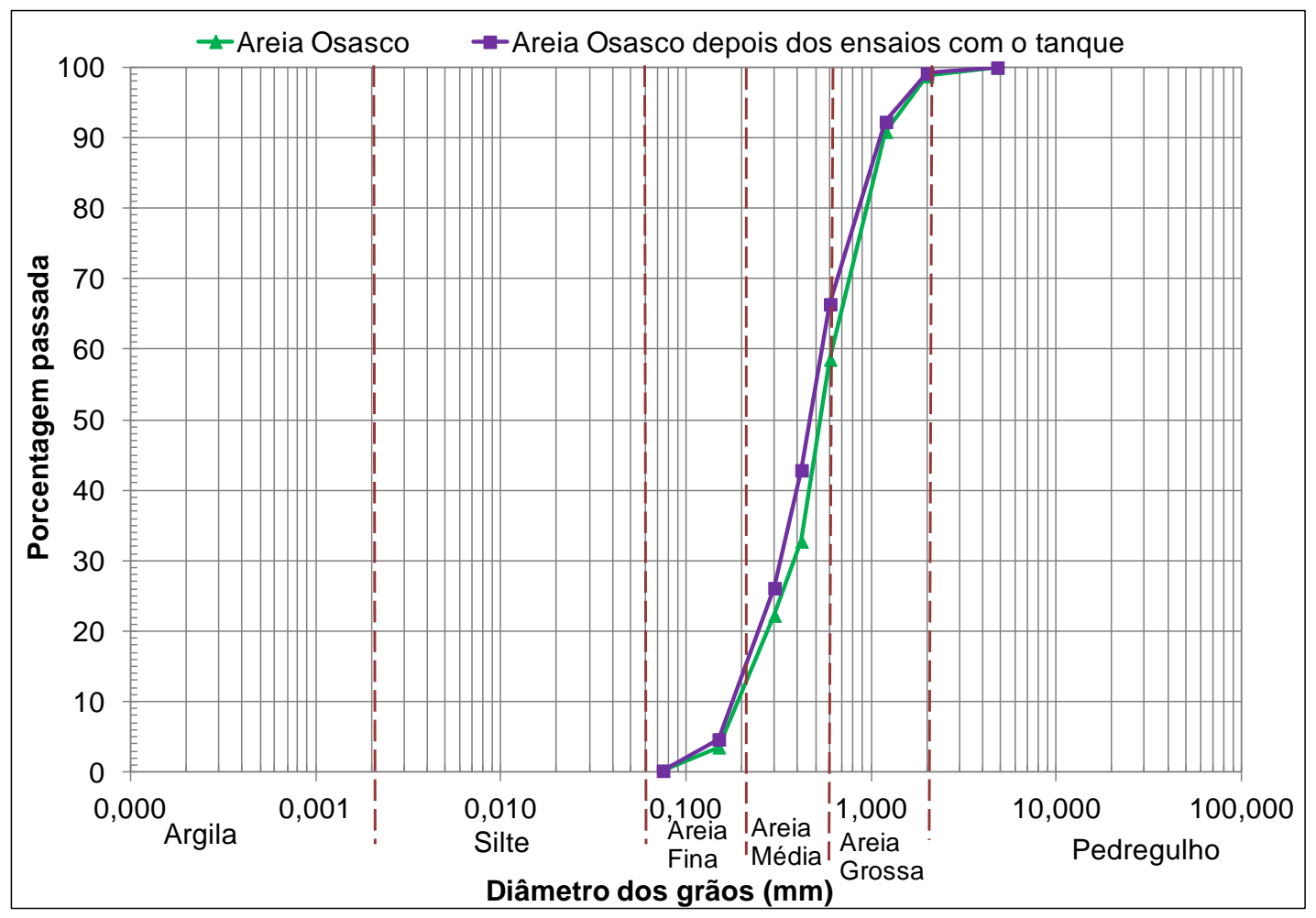

Figura 7.11 - Curvas granulométricas da Areia Osasco antes e depois dos ensaios com o tanque. 
Como não ocorreu perda de material durante a homogeneização com a Areia Osasco, o ensaio de granulometria depois dos ensaios não foi realizado para a Areia do IPT.

No segundo, terceiro e quarto ensaios a areia que já se encontrava no tanque foi revolvida para uma maior homogeneização da mesma.

\subsubsection{Ensaios com a Areia Osasco Depois da Homogeneização}

No segundo ensaio a injeção de ar e a vazão foram medidas, os resultados se encontram na Tabela 7.3. Com uma pressão de injeção de $13 \mathrm{kPa}$ notou-se que $\mathrm{o}$ ar começou a entrar no solo. O nível d'água se encontrava a $4,5 \mathrm{~cm}$ da superfície do solo.

Tabela 7.3 - Medidas de pressão de injeção de ar e vazão no segundo ensaio com a Areia Osasco.

\begin{tabular}{cc}
\hline Pressão de injeção (kPa) & Vazão (L/s) \\
\hline 13 & $<0,2$ \\
14,5 & 0,2 \\
16 & Pico de 0,3 e depois estabilizou em 0,2 \\
20 & 0,35 \\
22 & 0,4 \\
25 & 0,65 \\
28 & Variação de 1 a 1,4 \\
\hline
\end{tabular}

$\mathrm{Na}$ Figura 7.12 tem-se a foto do segundo ensaio, a área mais clara no meio do tanque representa os caminhos de ar formados durante a injeção com uma pressão de $13 \mathrm{kPa}$, com a injeção de ar o solo que estava saturado começa a dessaturar com a entrada do ar, formando assim os caminhos vistos na figura. 


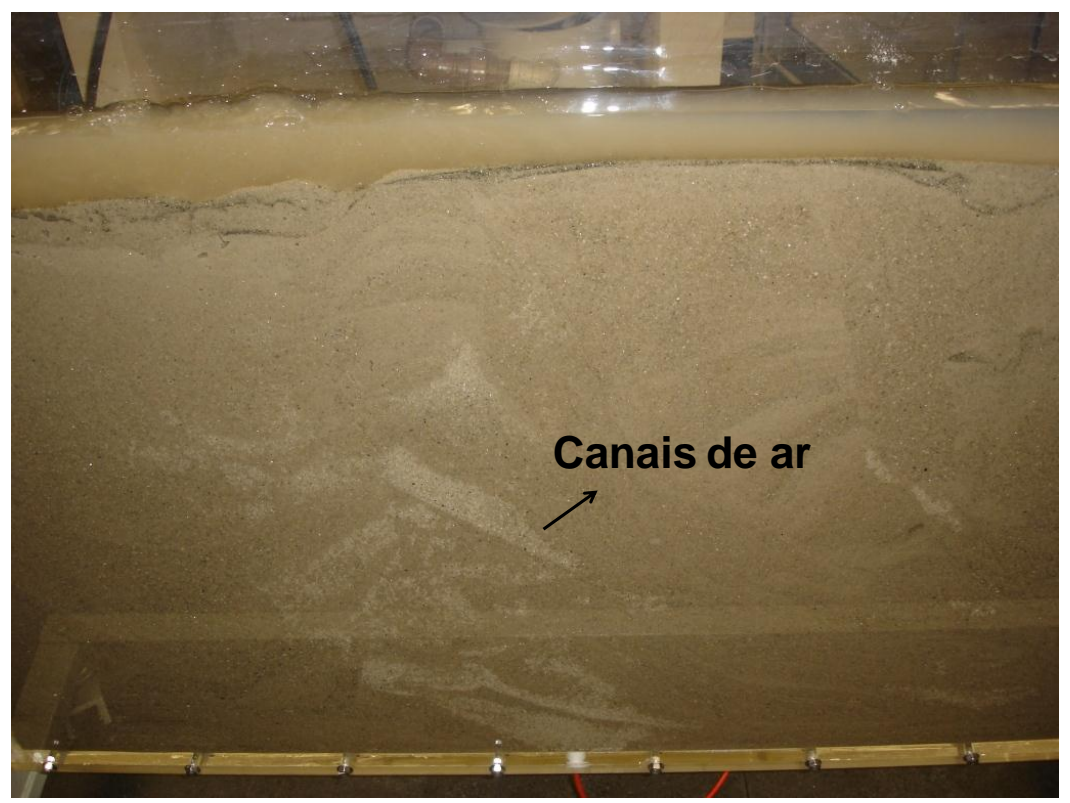

Figura 7.12 - Formação de canais de ar no segundo ensaio, Areia Osasco.

A Figura 7.13 apresenta um desenho esquemático da interpretação dos canais formados durante a injeção no segundo ensaio. Os desenhos dos canais de ar foram feitos no programa da Microsoft Office PowerPoint 2007. Como neste caso a deposição da areia não foi homogênea a zona de influência encontrada não foi simétrica. Pode-se notar que no lado direto do tanque houve apenas a formação de alguns canais de ar, isso aconteceu porque o ar encontrou alguma camada de solo mais impermeável nesse trecho do tanque, formando um caminho preferencial para o ar em outro trecho. Na Figura 7.13 também é possível notar que se formaram ramos mortos que são canais de ar que não atingiram a superfície, se tornando ineficaz durante uma descontaminação. 


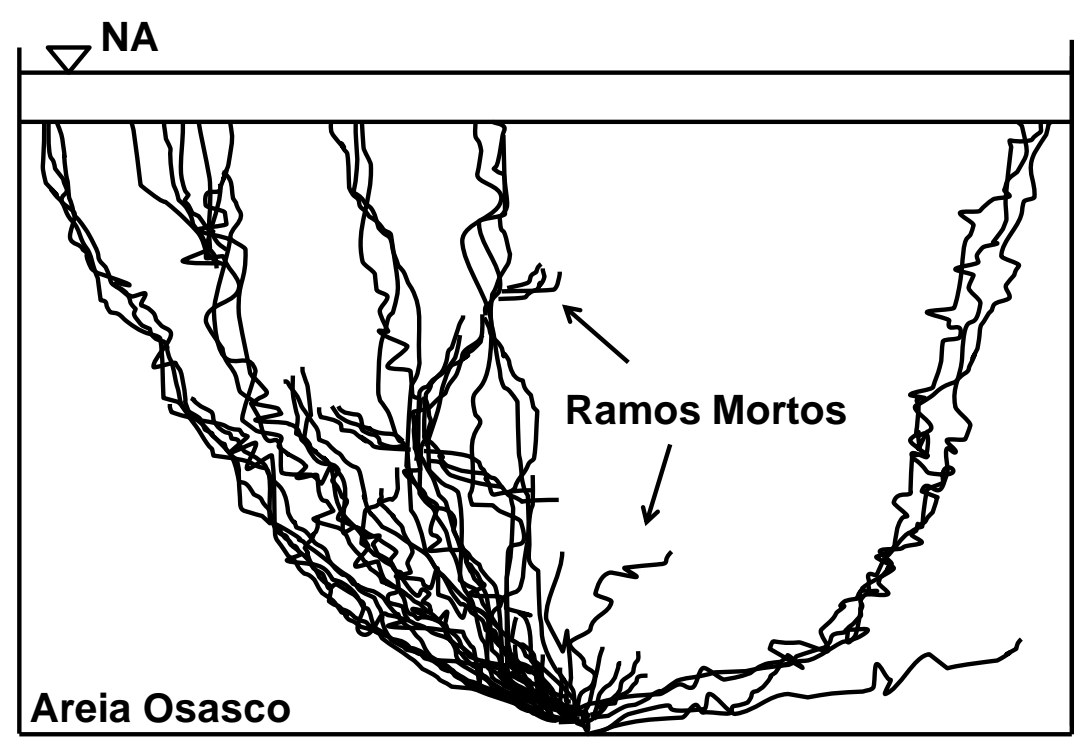

Figura 7.13 - Desenho esquemático mostrando o caminho seguido pelo ar durante a injeção, no segundo ensaio.

No terceiro ensaio fez-se novamente uma homogeneização no material que já se encontrava no tanque. O nível d'água durante o ensaio ficou $4,5 \mathrm{~cm}$ acima da superfície do solo. Neste ensaio as vazões medidas foram maiores do que no segundo. $\mathrm{O}$ ar começou a entrar no solo com a pressão de injeção de $13 \mathrm{kPa}$ assim como no segundo ensaio. Na Tabela 7.4 encontram-se os resultados das vazões durante a injeção de ar. O aumento da pressão de injeção foi feito imediatamente após não se notar a formação de canais de ar no modelo físico, mas percebe-se que para uma pressão de $7 \mathrm{kPa}$ já se tinha uma pequena vazão. Provavelmente se deixasse a injeção de ar com $7 \mathrm{kPa}$ por um tempo (até o equilíbrio do sistema) o ar tivesse superado a pressão de entrada de ar do solo.

Tabela 7.4 - Medidas de pressão de injeção de ar e vazão no terceiro ensaio com a Areia Osasco.

\begin{tabular}{cc}
\hline Pressão de injeção (kPa) & Vazão (L/s) \\
\hline 7 & 0,4 \\
10 & 0,55 \\
13 & Variação de 1,0 a 1,2 \\
15 & Variação de 1,4 a 1,5 \\
20 & 1,5 \\
25 & 1,7 \\
\hline
\end{tabular}


$\mathrm{Na}$ Figura 7.14 pode ser visto o sistema preparado para o terceiro ensaio com a Areia Osasco. Percebe-se que a areia formou algumas camadas de grãos mais finos em determinados lugares.

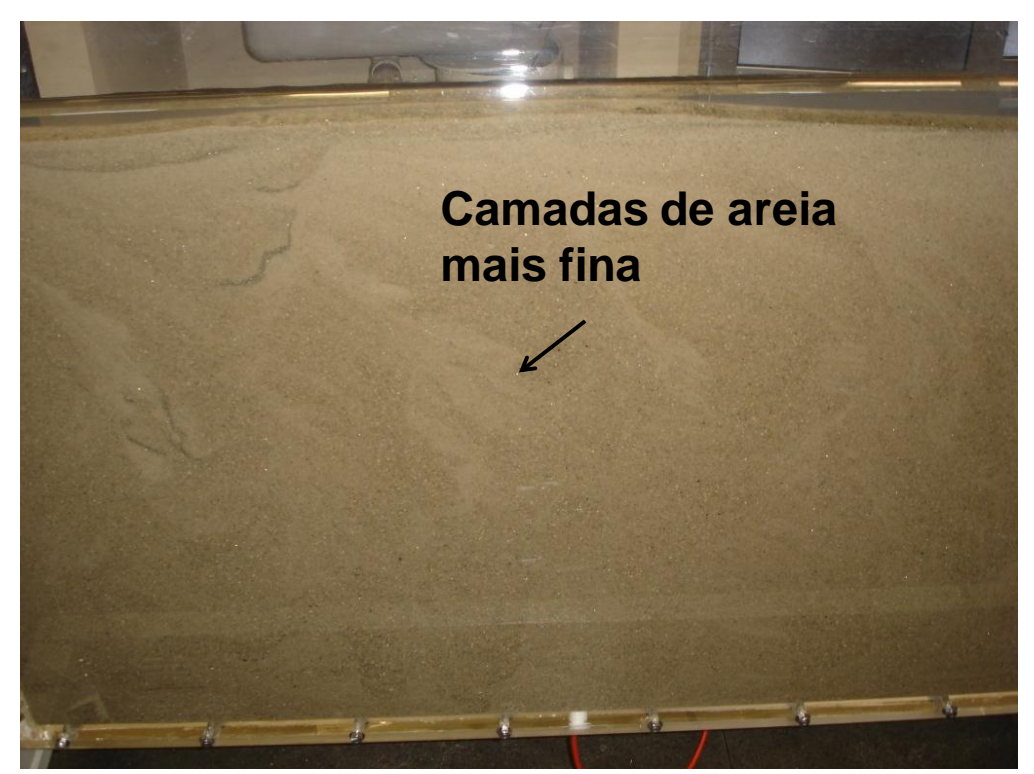

Figura 7.14 - Foto do arranjo do tanque antes do terceiro ensaio.

Na Figura 7.15 é apresentada a foto com os canais de ar formados durante o terceiro ensaio. Percebe-se a dessaturação de água no solo devido à injeção de ar. Pode-se notar que os caminhos de ar se formaram preferencialmente no lado esquerdo do tanque assim como na Figura 7.12.

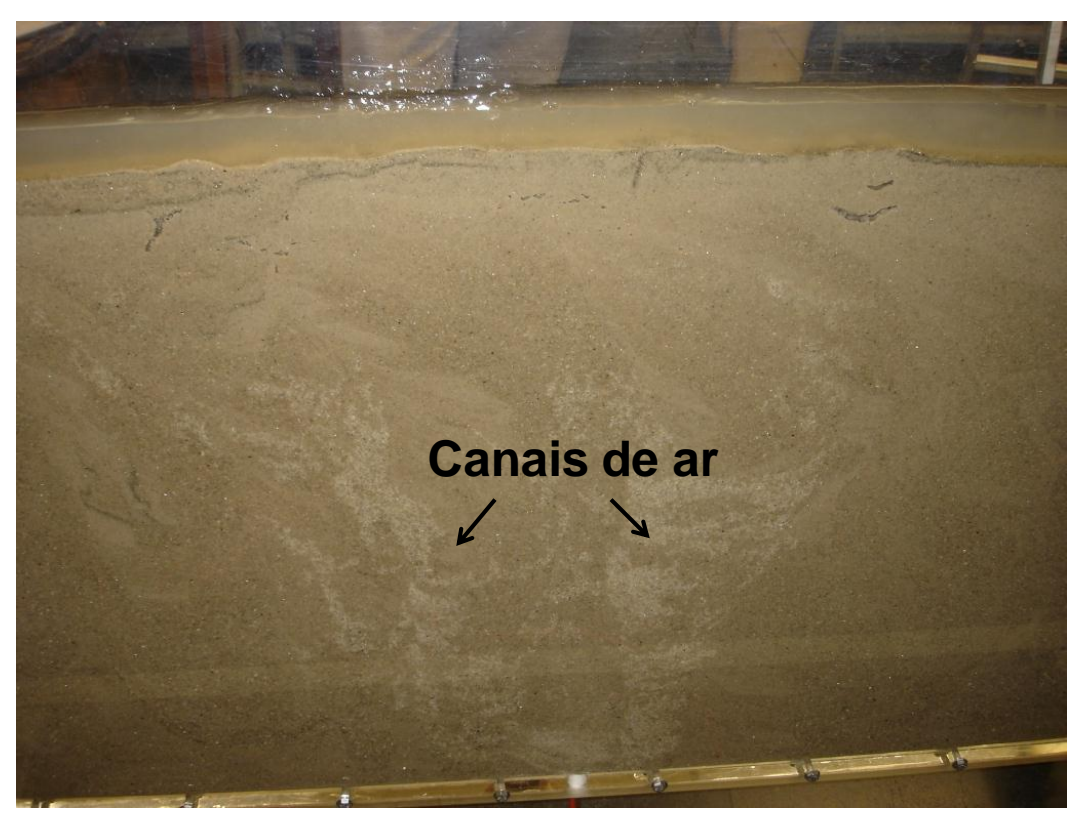

Figura 7.15 - Formação de canais de ar no terceiro ensaio, Areia Osasco. 
A Figura 7.16 apresenta o desenho esquemático da interpretação dos canais formados durante o terceiro ensaio com a Areia Osasco. A homogeneização feita antes do início deste ensaio foi mais eficiente do que a feita para o segundo ensaio, pois como pode ser observado na Figura 7.16 mais canais de ar foram formados.

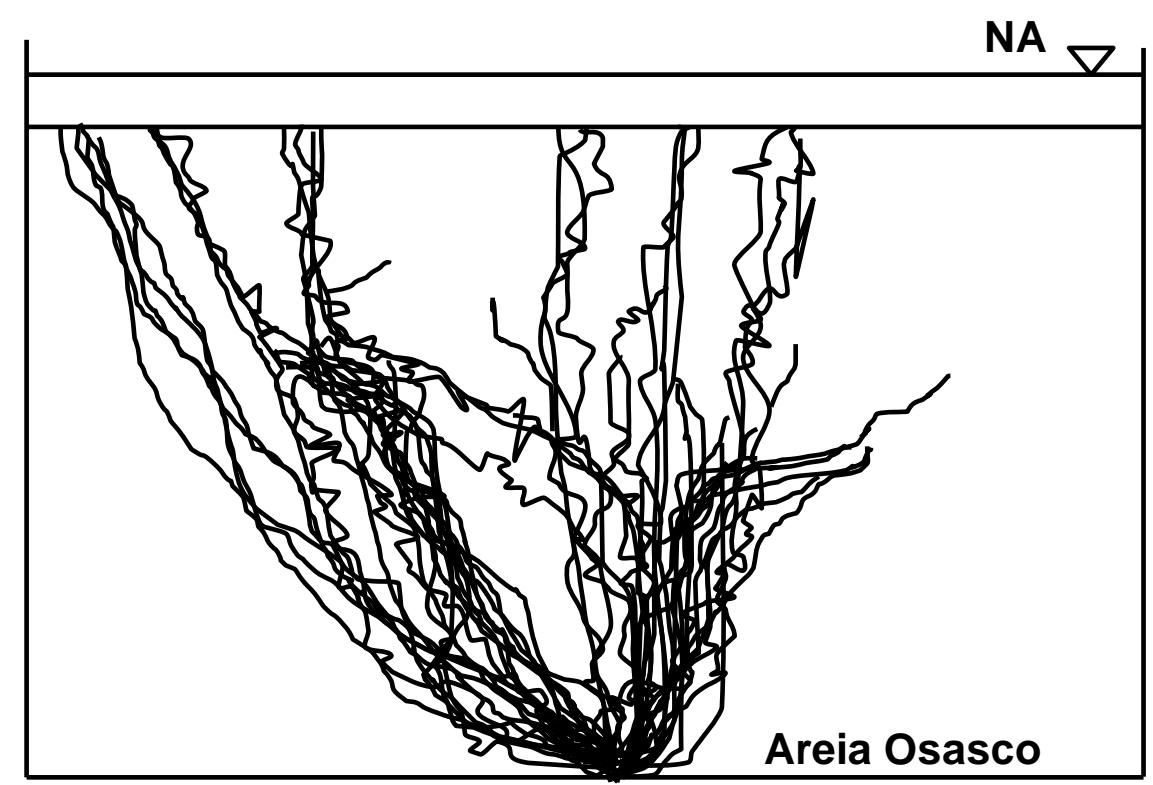

Figura 7.16 - Desenho esquemático mostrando os canais de ar formados no terceiro ensaio.

Para o quarto ensaio, assim como para o segundo e terceiro, tentou-se mais uma vez homogeneizar a areia. No entanto, como pode ser observado adiante não se obteve sucesso. Neste ensaio a vazão de $20 \mathrm{kPa}$ não pode ser medida pois extrapolou a leitura máxima do rotômetro. $\mathrm{O}$ ar começou a penetrar no solo com uma pressão de $13 \mathrm{kPa}$ assim como nos outros testes. A aproximadamente $5 \mathrm{~cm}$ acima da superfície do solo se encontrava o nível d'água. A Tabela 7.5 apresenta os resultados de vazão encontrados durante a injeção de ar no quarto ensaio. 
Tabela 7.5 - Medidas de pressão de injeção de ar e vazão no quarto ensaio com a AreiaOsasco.

\begin{tabular}{cc}
\hline Pressão de injeção (kPa) & Vazão (L/s) \\
\hline 7 & 0,25 \\
10 & 0,35 \\
12 & 0,45 \\
13 & Variação de 1,1 a 1,2 \\
15 & 1,4 \\
20 & - \\
\hline
\end{tabular}

$\mathrm{Na}$ Figura 7.17 podem ser vistos os canais de ar no quarto ensaio. Observa-se que 0 fluxo de ar formado tem um caminho preferencial, o ar percorreu mais o lado esquerdo do tanque do que o direito. Diferente do que aconteceu no primeiro teste em que o fluxo de ar encontrou caminho preferencial pelo lado direito do tanque. Com isso percebe-se que não houve êxito na homogeneização realizada antes da injeção de ar, tendo sido criada uma condição heterogênea.

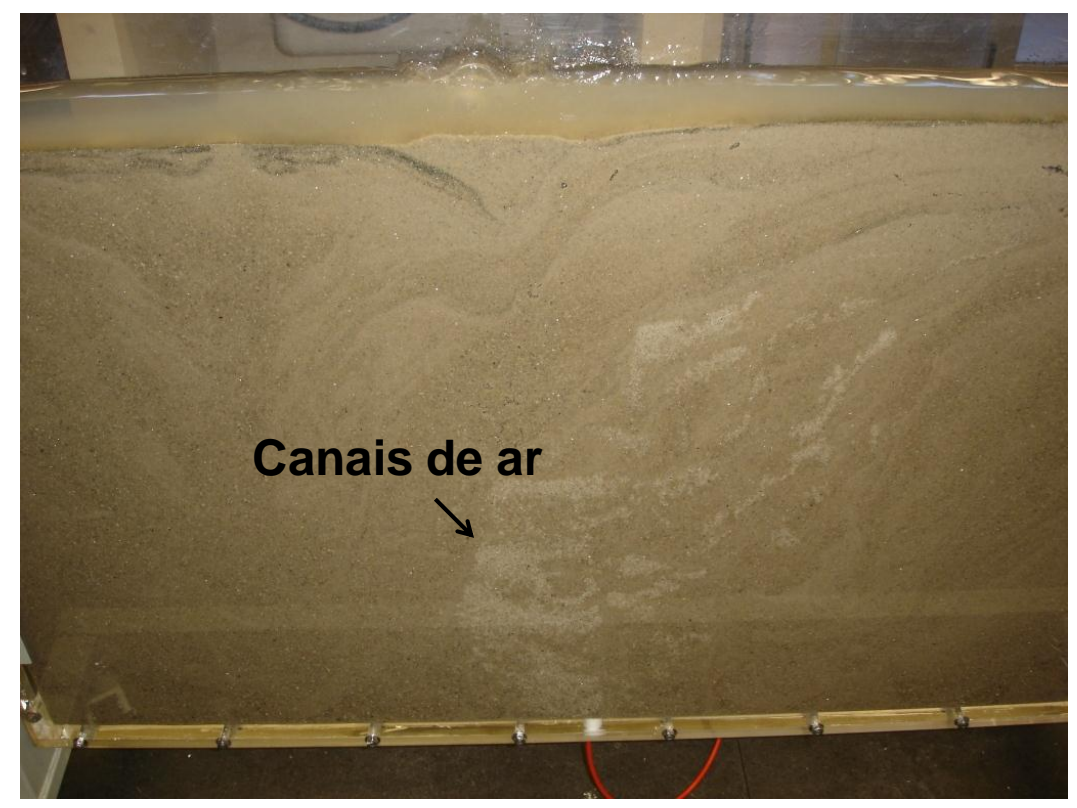

Figura 7.17 - Formação de canais de ar no quarto ensaio, Areia Osasco.

A Figura 7.18 apresenta o desenho esquemático da interpretação dos canais de ar formados durante a injeção. 


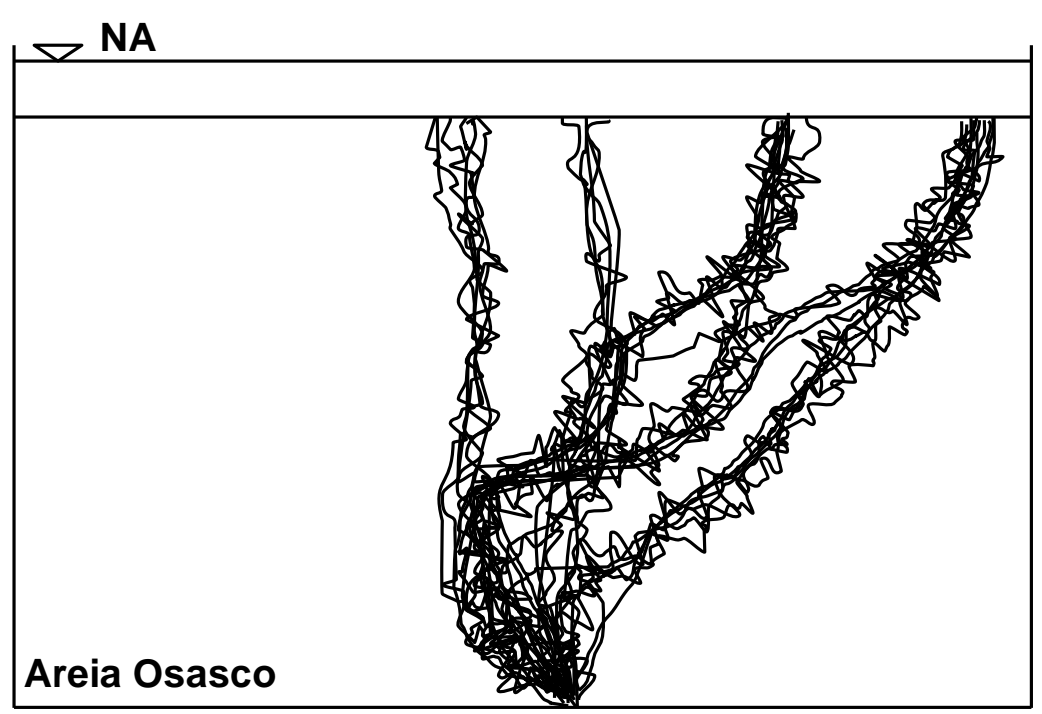

Figura 7.18 - Desenho esquemático mostrando os canais de ar formados durante o quarto ensaio.

Nos ensaios realizados até aqui a interpretação dos canais de ar foram feitas logo após o ar entrar no solo. Entretanto foi visto na literatura que após algum tempo o fluxo entra em equilíbrio e a zona de influência diminui. Ao fim do quarto ensaio a injeção de ar ficou ligada durante 1 hora e pode-se notar essa diminuição da zona de influência, como pode ser observado na Figura 7.19-(a) e (b). Em (a) tem-se a zona de influência logo após a aplicação da pressão de $20 \mathrm{kPa}$ e em (b) 1 hora depois da aplicação contínua da mesma pressão.
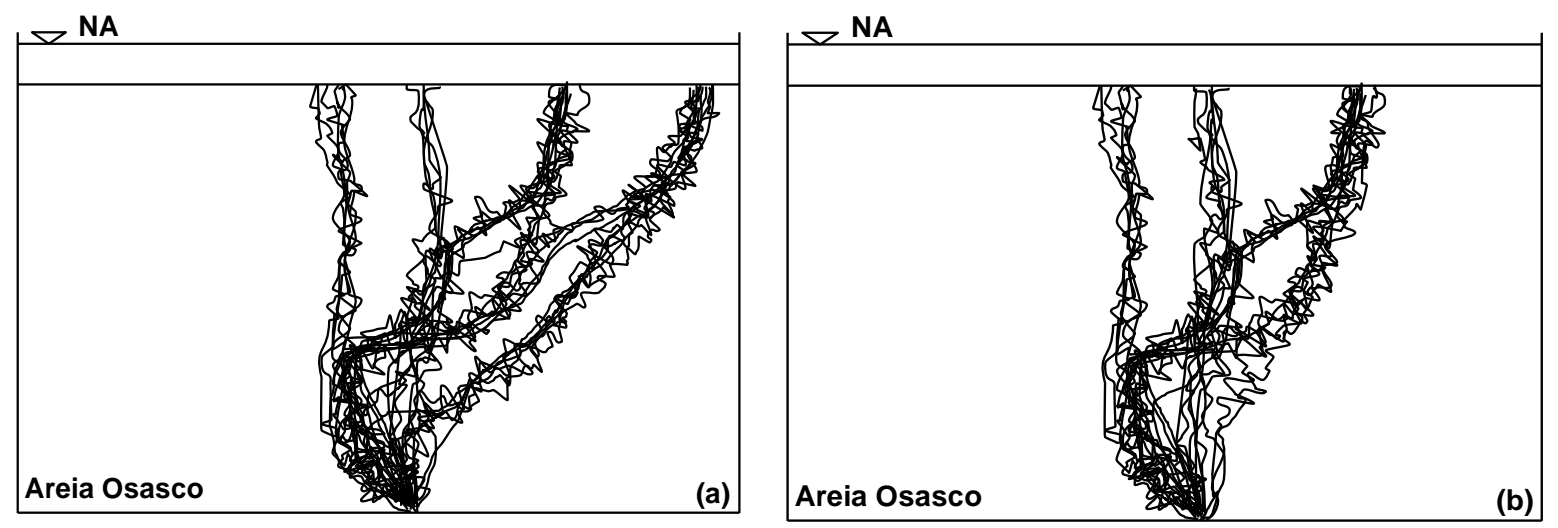

Figura 7.19 - Desenhos dos caminhos de ar durante o quarto ensaio. Em (a) logo após a aplicação e em (b) 1 hora após a aplicação contínua da mesma pressão.

O quinto ensaio com a Areia Osasco no tanque assim como o primeiro foi realizado com a areia em camadas, a única diferença entre os ensaios é que durante o primeiro a pressão de entrada de ar não foi controlada e nem medida. Para a 
realização deste ensaio a pressão de injeção foi acrescida gradualmente de 7,10 , 12,13 e $15 \mathrm{kPa}$; o ar começou a entrar no solo com uma pressão de $15 \mathrm{kPa}$ e a vazão medida para esta pressão foi de $0,9 \mathrm{~L} / \mathrm{s}$.

No quinto ensaio foram utilizados $31,8 \mathrm{Kg}$ de areia que atingiram uma altura de 60 $\mathrm{cm}$ no tanque, com isso a areia ficou com um índice de vazios de 0,65 e porosidade de 0,39 . O nível d'água se encontrava $2 \mathrm{~cm}$ acima da superfície do solo.

A entrada de ar medida neste ensaio foi mais alta do que as dos ensaios anteriores (segundo, terceiro e quarto) que foi de $13 \mathrm{kPa}$; isso era esperado já que as camadas formadas durante a montagem do ensaio criaram uma resistência na passagem do ar. Na Figura 7.20 pode ser observado o tanque antes do ensaio, nota-se a estratificação fruto da presença das camadas de material mais fino sobre o mais grosso devido à sedimentação da areia durante o processo de montagem.

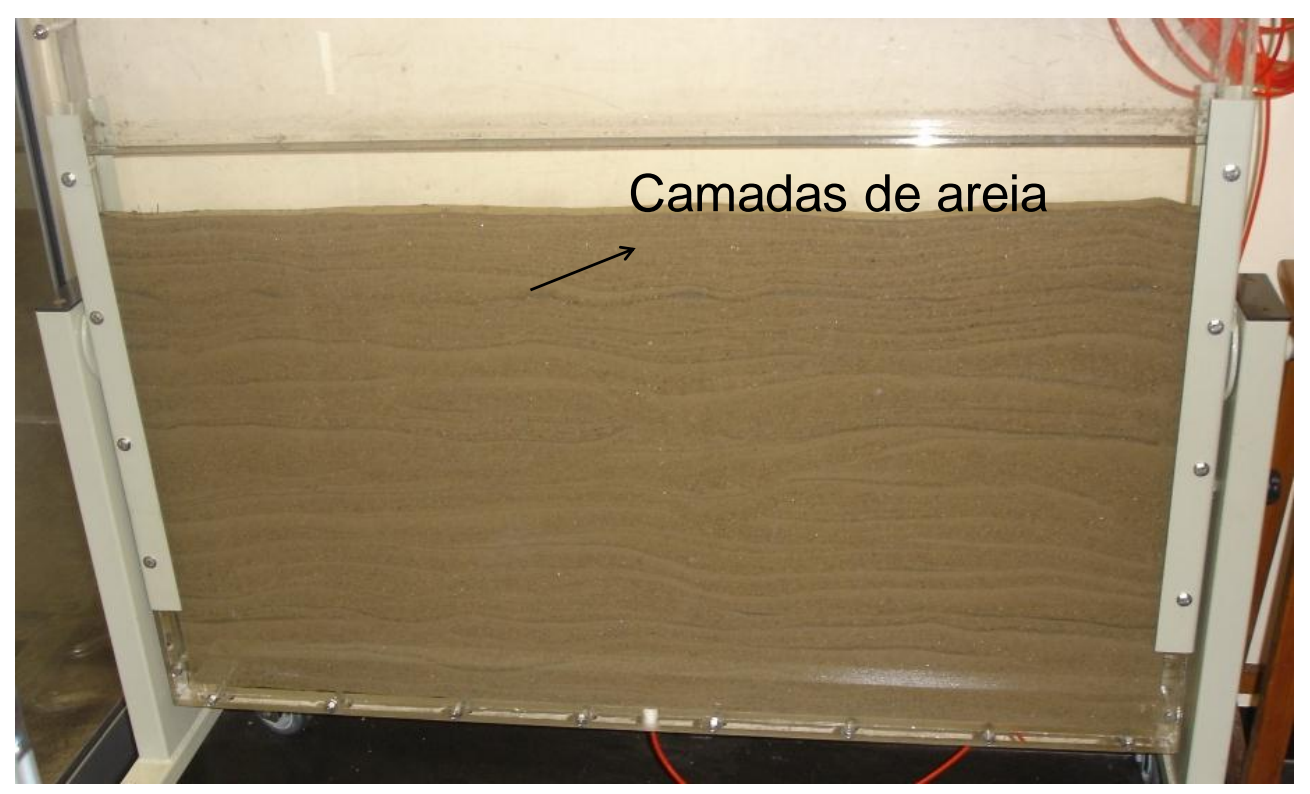

Figura 7.20 - Quinto ensaio da Areia Osasco antes da injeção de ar.

Durante o processo de sedimentação a areia mais grossa ficou embaixo da areia mais fina, ou seja, o material mais permeável ficou por baixo do material menos permeável. É por esse motivo que o ar ao ser injetado se moveu lateralmente, pois ao encontrar a pequena camada de areia mais fina 0 ar preferiu se mover lateralmente devido à menor permeabilidade horizontal; isto aconteceu durante toda a extensão do tanque por causa das várias camadas de areia formadas. A Figura 
7.21 mostra o tanque durante a injeção de ar. É possível notar os canais de ar devido à dessaturação do solo que está representa na foto pela parte mais clara.

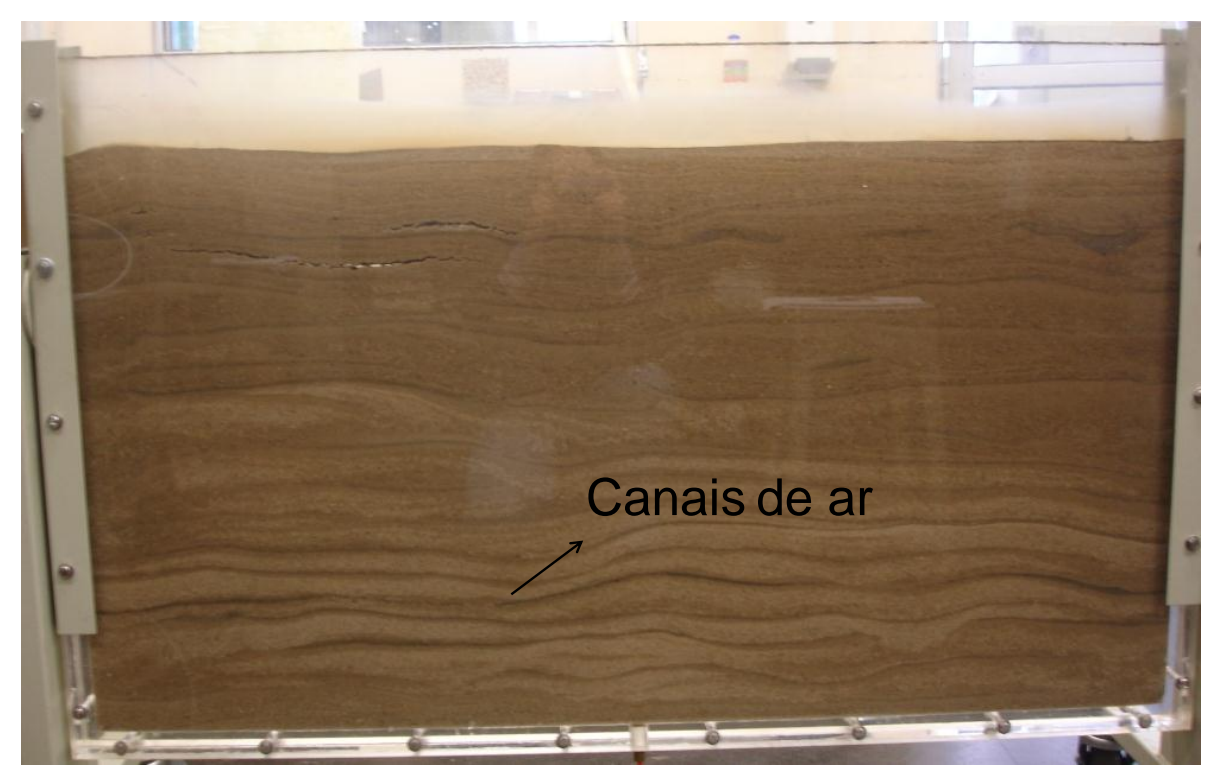

Figura 7.21 - Detalhe dos canais de ar formados durante a injeção de ar no quinto ensaio.

A Figura 7.22 apresenta o desenho esquemático da interpretação dos canais de ar formados durante a injeção no quinto ensaio com a Areia Osasco.

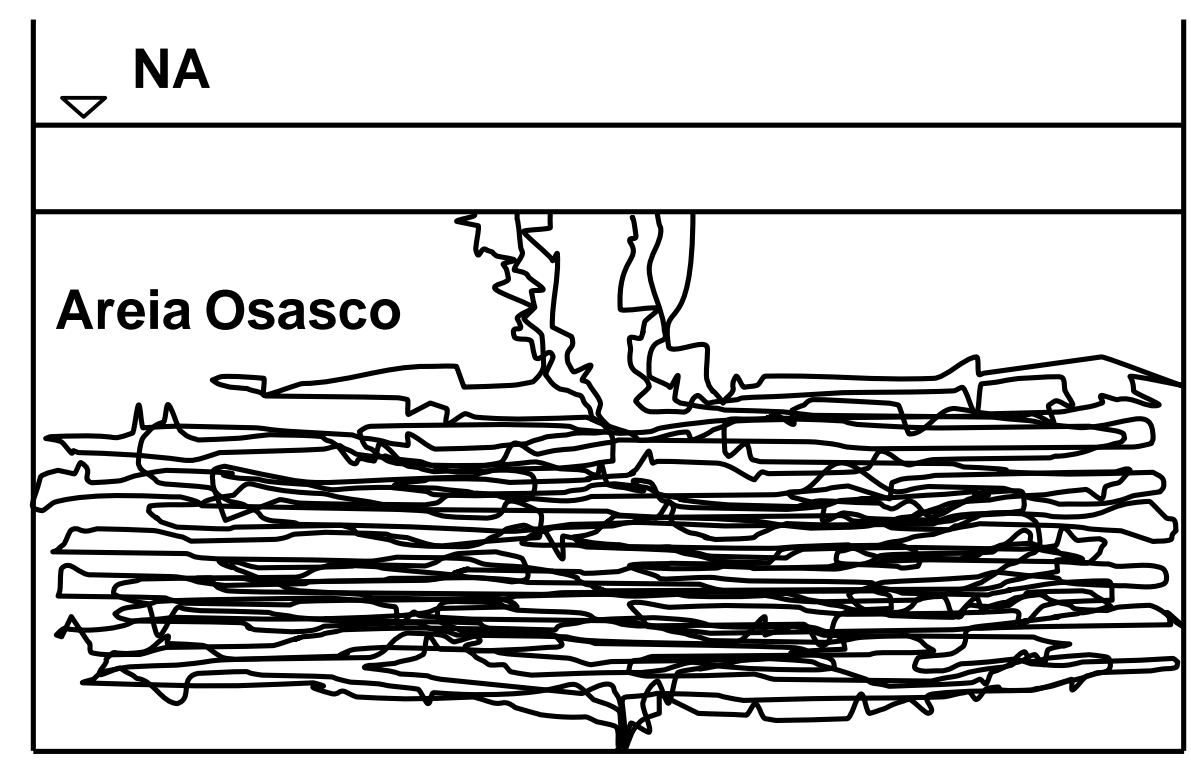

Figura 7.22 - Desenho esquemático mostrando os canais de ar, quinto ensaio da Areia Osasco.

A Figura 7.23-(a) apresenta as camadas de solo antes da injeção de ar já nas Figura 7.23-(b), (c) e (d) pode ser observada a evolução dos caminhos de ar formados; 
nota-se que as paredes laterais do tanque impediram a passagem do ar obrigando-o a se mover verticalmente. Também é possível perceber que o ar subiu até a superfície passando de camada em camada, sendo que a direção preferencial do movimento foi horizontal. As setas representadas na figura indicam o sentido do movimento do fluxo de ar.

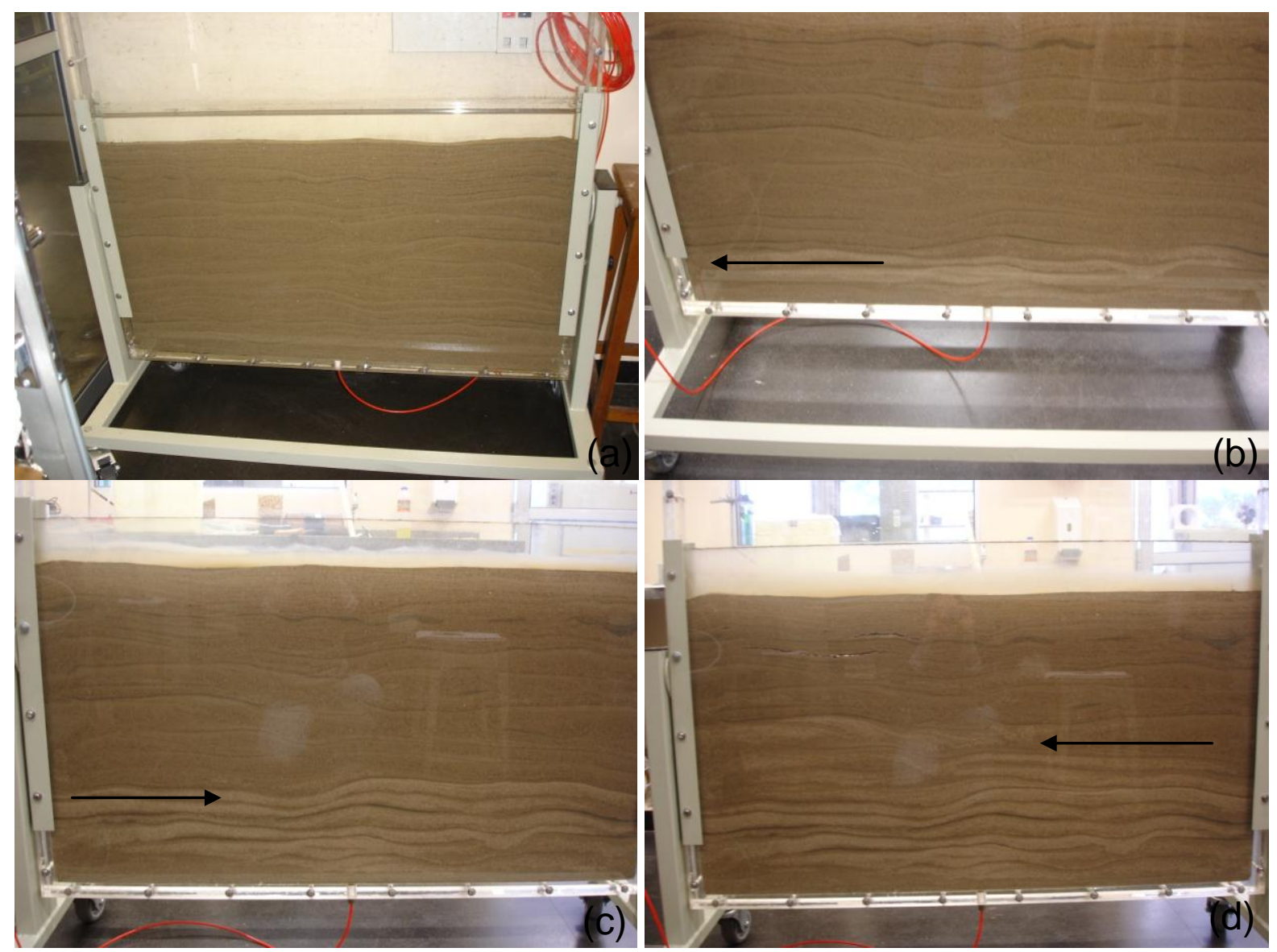

Figura 7.23 - Quinto ensaio com a Areia Osasco, processo de formação dos canais de ar.

Observa-se a presença de bolhas de ar presas no solo como a bolha formada neste quinto ensaio, ver Figura 7.24-(a). As camadas de areia ficaram mais estreitas perto da superfície do solo fazendo com que o ar não conseguisse se mover lateralmente devido à pequena espessura do material mais permeável; a pressão para que o ar conseguisse se mover verticalmente tinha que ser maior do que para o movimento lateral; isto causou a formação da bolha de ar que se desfez quando a pressão de injeção superou a entrada de ar do material mais fino, como mostra a Figura 7.24(b). Solos finos têm uma maior probabilidade de formação de bolsões de ar; o que pode diminuir a eficiência do método. 


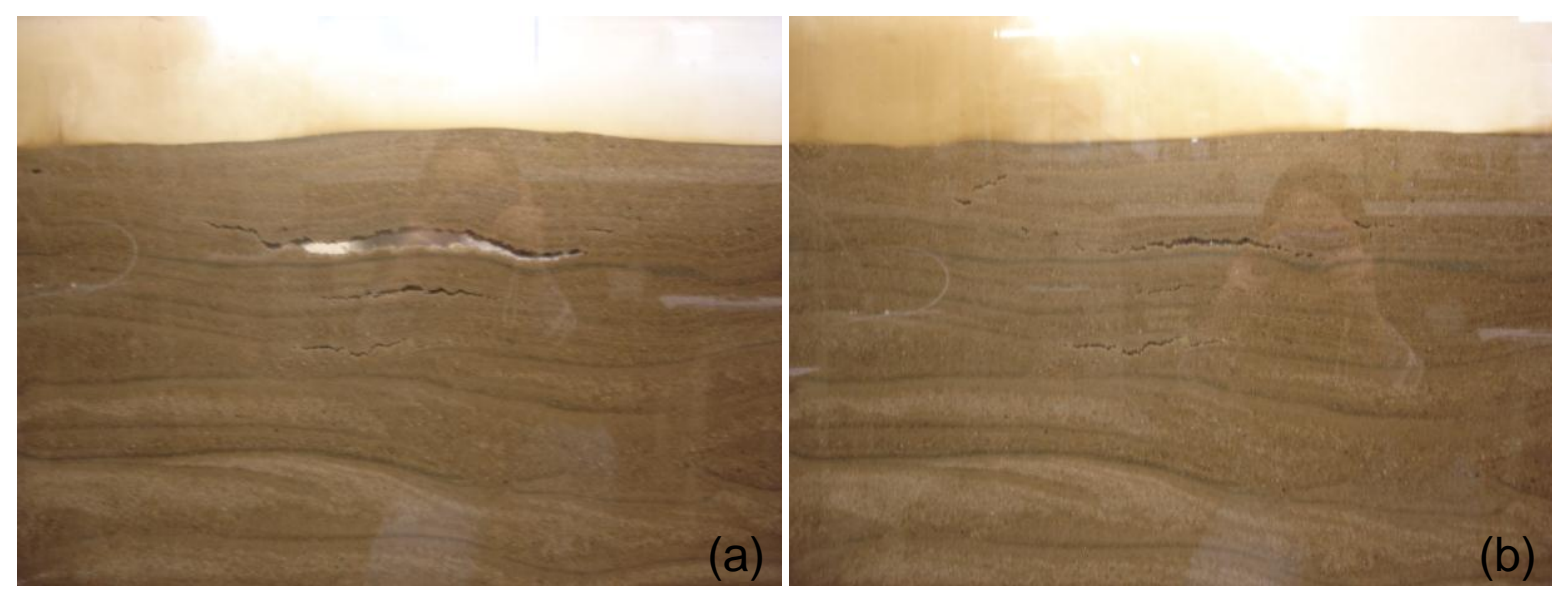

Figura 7.24 - Formação e desaparecimento de bolha de ar próximo a superfície durante o quinto ensaio, Areia Osasco.

\subsubsection{Areia do IPT}

A Areia do IPT, como explicado no Capítulo 6, é uma areia comercial uniforme com tamanho médio dos grãos de 0,3 mm (\# 50). Foram realizados os ensaios com o modelo físico (tanque) para este solo para mostrar a diferença de comportamento do fluxo de ar para solos uniformes e homogêneos (Areia do IPT) e heterogêneos (Areia Osasco).

Foram realizados três ensaios com a Areia do IPT no modelo físico, cada um com um arranjo diferente de solo causando uma mudança no comportamento de fluxo como pode ser observado na Tabela 7.6.

Tabela 7.6 - Descrição dos ensaios realizados com a Areia do IPT no modelo físico.

\begin{tabular}{|c|c|c|}
\hline Ensaio & Característica do Solo & Comportamento do Fluxo \\
\hline 1 & $\begin{array}{l}\text { Solo depositado no tanque por } \\
\text { sedimentação (com controle da } \\
\text { vazão e pressão de injeção) }\end{array}$ & $\begin{array}{l}\text { Movimento lateral acentuado, zona de } \\
\text { influência simétrica. }\end{array}$ \\
\hline 2 & 1a Homogeneização & $\begin{array}{l}\text { Zona de influência simétrica, fluxo } \\
\text { vertical saindo do ponto de injeção de ar. }\end{array}$ \\
\hline 3 & 2ª Homogeneização & $\begin{array}{l}\text { Zona de influência simétrica, fluxo } \\
\text { vertical saindo do ponto de injeção de ar. }\end{array}$ \\
\hline
\end{tabular}


Para a realização do ensaio a Areia do IPT foi introduzida no tanque da mesma maneira que a Areia Osasco, ou seja, primeiramente o tanque foi preenchido com água e em seguida a areia foi inserida no tanque através de um funil feito de garrafa PET, simulando a sedimentação natural do solo na natureza.

Foram colocados $27,9 \mathrm{~kg}$ de Areia do IPT que atingiu uma altura de $60 \mathrm{~cm}$ no tanque. Como o volume interno do tanque é conhecido o índice de vazios e a porosidade foram calculados obtendo os seguintes resultados 0,86 e 0,46 , respectivamente. O nível d'água se encontrava a $17 \mathrm{~cm}$ da superfície do solo.

O primeiro ensaio foi realizado com a areia em "camadas" para se obter uma comparação entre as duas areias utilizadas neste estudo. Na Figura 7.25 pode ser visto o arranjo das partículas de solo no tanque antes da injeção de ar e também podem ser vistas as camadas de areia fina formadas durante a sedimentação. Mesmo sendo um material uniforme certo teor de areia fina está presente.

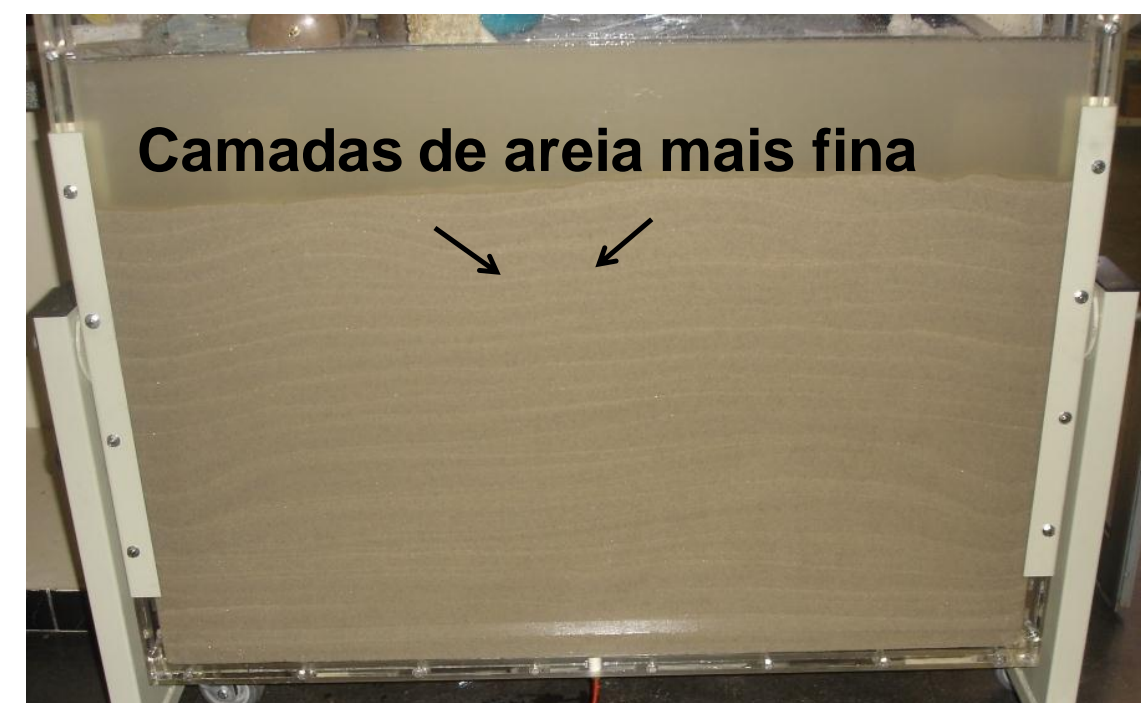

Figura 7.25 - Primeiro ensaio Areia do IPT, arranjo em camadas.

No primeiro ensaio com a Areia do IPT notou-se uma acentuada movimentação lateral do ar devido à formação das camadas de material mais fino sobre material mais grosso durante a colocação da areia no tanque. Na Figura 7.26 pode ser observada a saída de ar do solo através das bolhas de ar vistas na água acima do solo. 


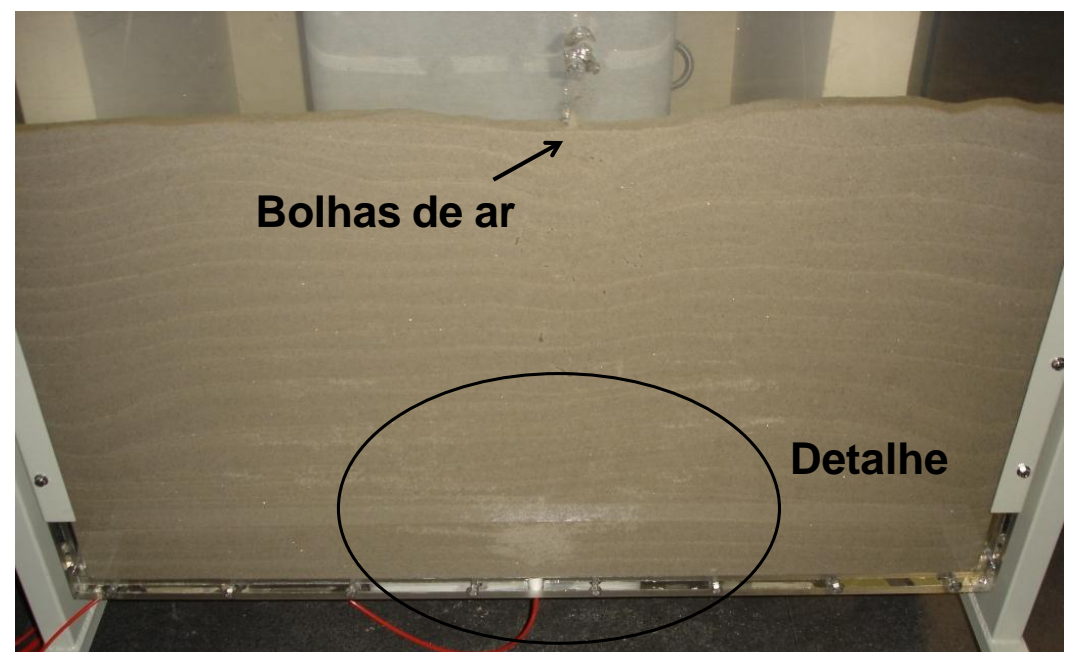

Figura 7.26 - Foto durante a injeção de ar no primeiro ensaio da Areia do IPT.

Na Figura 7.27 tem-se o detalhe dos canais de ar, que podem ser notados através da dessaturação da água no solo, e também é visto a preferência do ar em se movimentar lateralmente.

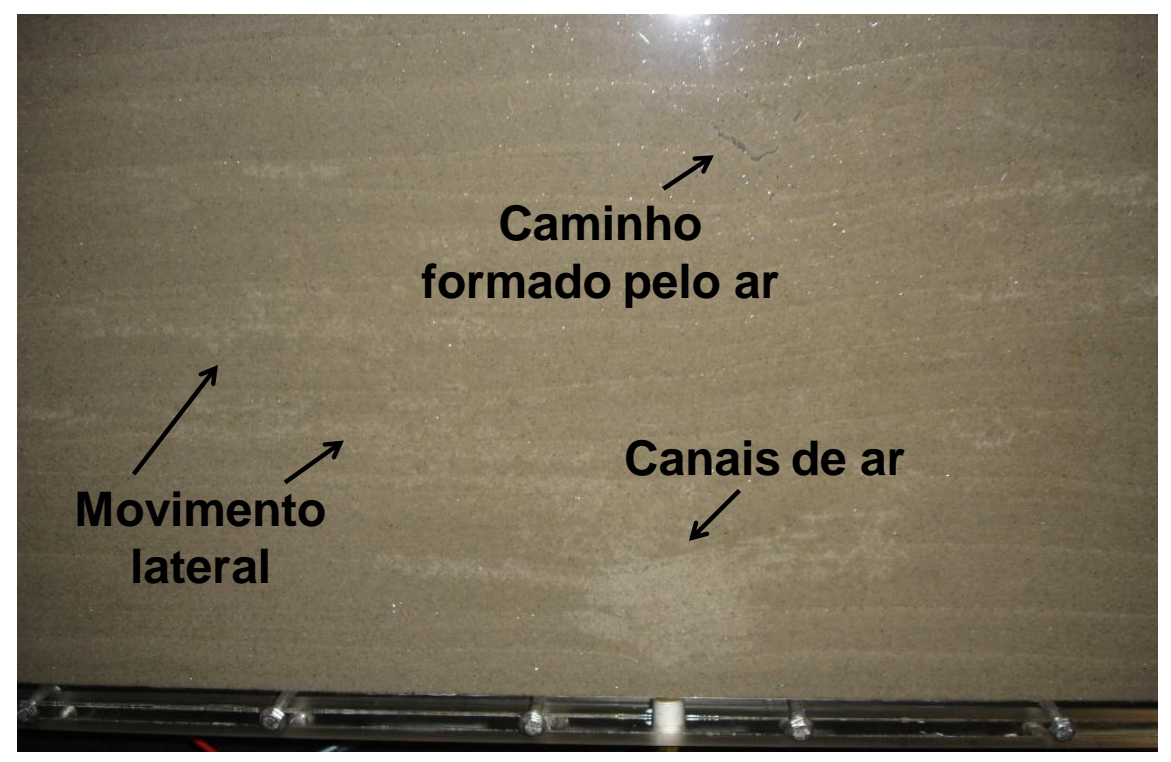

Figura 7.27 - Detalhe dos canais de ar formados durante a injeção, nota-se o movimento lateral.

A Figura 7.28 mostra o desenho esquemático da interpretação dos canais de ar formados durante a injeção. Nota-se que a zona de influência formada foi simétrica devido à maior homogeneidade da areia utilizada. Seu formato é de um U mesmo para baixas pressões de injeção. 


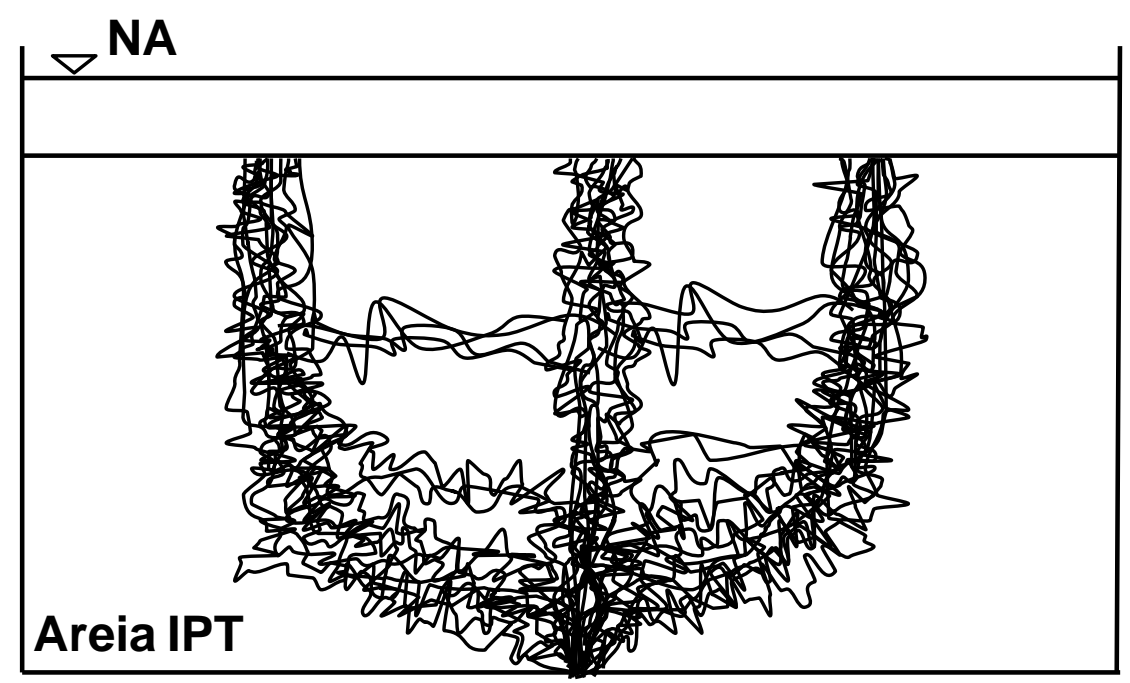

Figura 7.28 - Desenho esquemático mostrando os canais de ar durante o primeiro ensaio com a Areia do IPT.

Foram medidas as vazões para cada pressão de injeção aplicada, os valores podem ser encontrados na Tabela 7.7. Para a pressão de $20 \mathrm{kPa}$ a leitura não foi realizada pois ultrapassou o limite do rotômetro. $\mathrm{O}$ ar começou a penetrar no solo com uma pressão de $16 \mathrm{kPa}$.

Tabela 7.7 - Medidas de pressão de injeção de ar e vazão no primeiro ensaio com a Areia do IPT.

\begin{tabular}{cc}
\hline Pressão de injeção (kPa) & Vazão (L/s) \\
\hline 7 & 0,2 \\
10 & 0,35 \\
13 & 0,4 \\
15 & 0,45 \\
16 & 1,3 \\
20 & - \\
\hline
\end{tabular}

O segundo ensaio com a Areia do IPT foi realizado com a areia que já se encontrava no tanque; antes do início do ensaio a areia passou pelo processo de homogeneização descrito anteriormente. Neste ensaio o ar começou a entrar no solo com uma pressão de injeção de $16 \mathrm{kPa}$ assim como no primeiro ensaio; e o nível d'água se encontrava $5 \mathrm{~cm}$ acima da superfície do solo. A Tabela 7.8 mostra os resultados das vazões encontradas para cada pressão de injeção aplicada. 
Tabela 7.8 - Medidas de injeção de ar e vazão no segundo ensaio com a Areia do IPT.

\begin{tabular}{cc}
\hline Pressão de injeção $\mathbf{( k P a )}$ & Vazão $\mathbf{( L / s )}$ \\
\hline 7 & 0,25 \\
10 & 0,35 \\
13 & 0,4 \\
15 & 0,45 \\
16 & 1,15 \\
\hline
\end{tabular}

A zona de influência formada, durante a injeção de ar no segundo ensaio com a Areia do IPT, também foi simétrica com ápice no ponto de injeção. Por se tratar de uma areia média e uniforme era esperado que a zona de influência formada fosse estreita. Na Figura 7.29 tem-se a foto do tanque durante a injeção de ar, nota-se que a zona de influência é estreita se formando apenas no ponto de injeção.

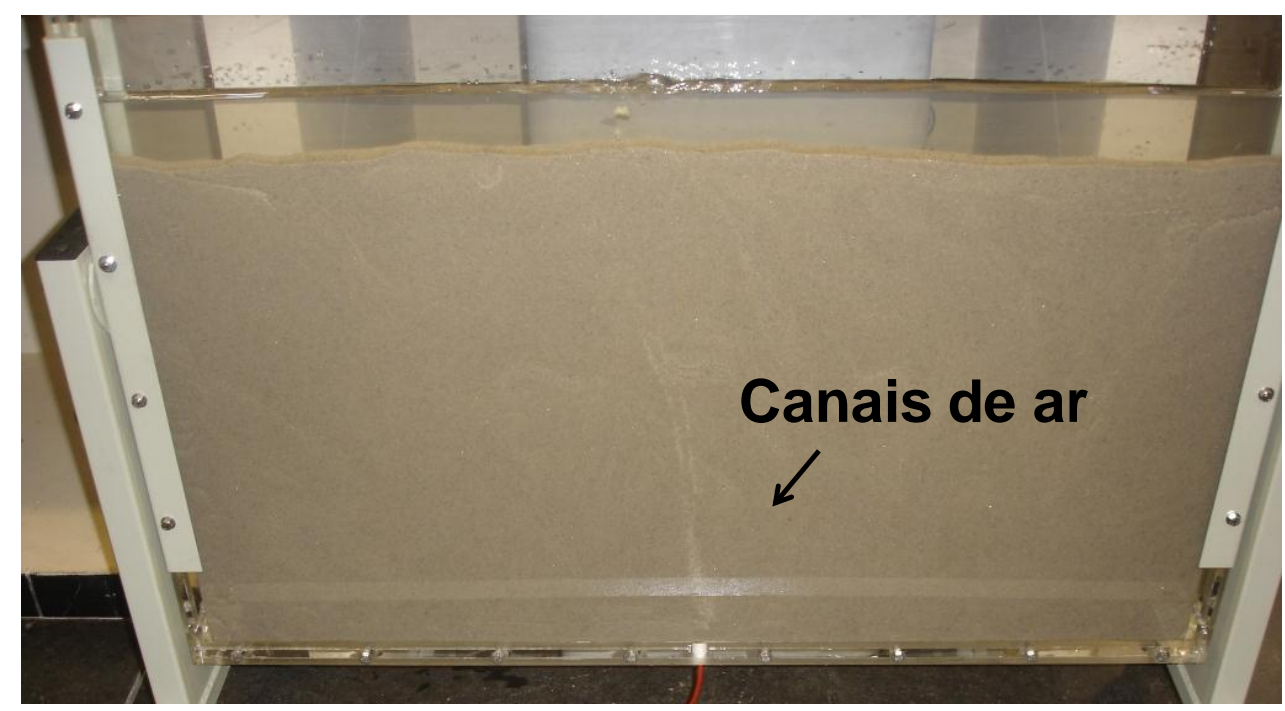

Figura 7.29 - Segundo ensaio com a Areia do IPT.

Após o término do segundo ensaio a Areia do IPT foi novamente homogeneizada e em seguida foi realizado o terceiro ensaio. O nível d'água se encontrava $9 \mathrm{~cm}$ acima da superfície do solo no terceiro ensaio e o ar começo a penetrar no solo com a pressão de injeção de $16 \mathrm{kPa}$. A Tabela 7.9 apresenta os resultados de vazão e pressão de injeção de ar. 
Capítulo 7 - Ensaios com o Modelo Físico Bidimensional em Laboratório

Tabela 7.9 - Medidas de pressão de injeção e vazão no terceiro ensaio com a Areia do IPT.

\begin{tabular}{cc}
\hline Pressão de injeção (kPa) & Vazão (L/s) \\
\hline 7 & 0,2 \\
10 & 0,3 \\
13 & 0,4 \\
15 & 0,5 \\
16 & 1,16 \\
\hline
\end{tabular}

A Figura 7.30 mostra o terceiro ensaio com a Areia do IPT, percebe-se a saída de ar do solo pelas bolhas formadas no nível d'água. A zona de influência formada foi muito semelhante a do segundo ensaio, devido à homogeneidade do solo utilizado.

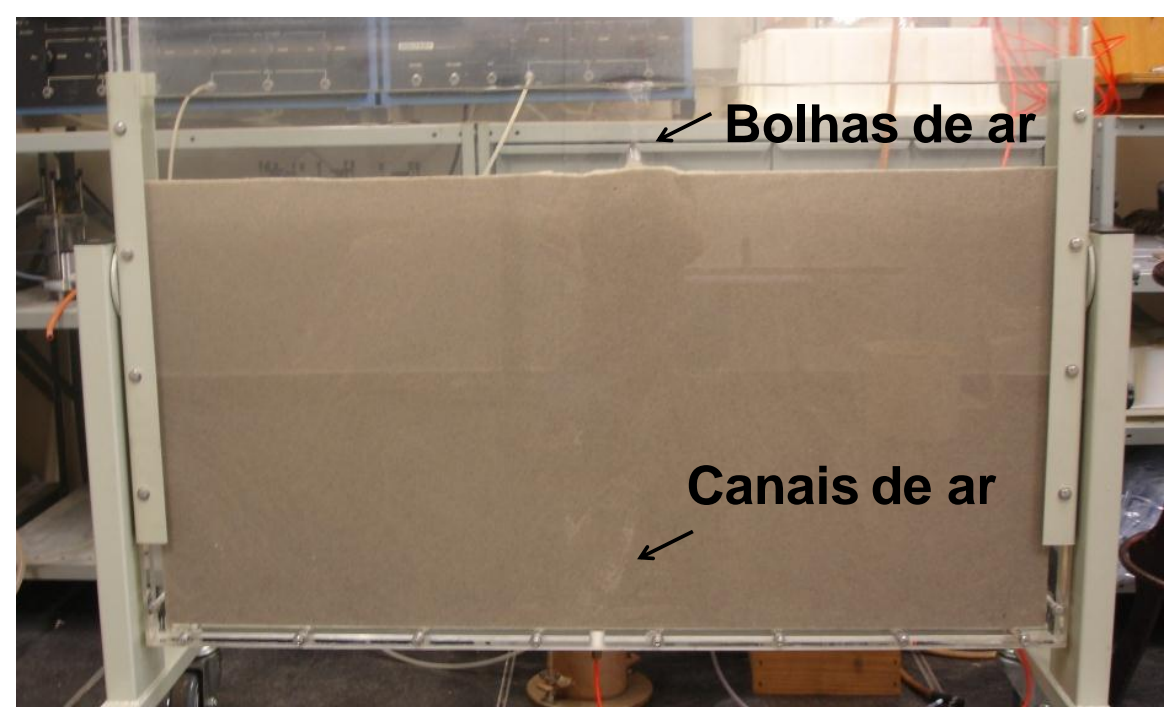

Figura 7.30 - Terceiro ensaio com a Areia do IPT.

A zona de influência formada foi estreita devido ao solo ser mal graduado, mas a densidade de canais na região atingida pelo ar é alta. Em solos com esse tipo de comportamento é necessária a instalação de mais poços de injeção de ar. A Figura 7.31 mostra o desenho esquemático dos canais de ar formados durante o segundo e o terceiro ensaio. 


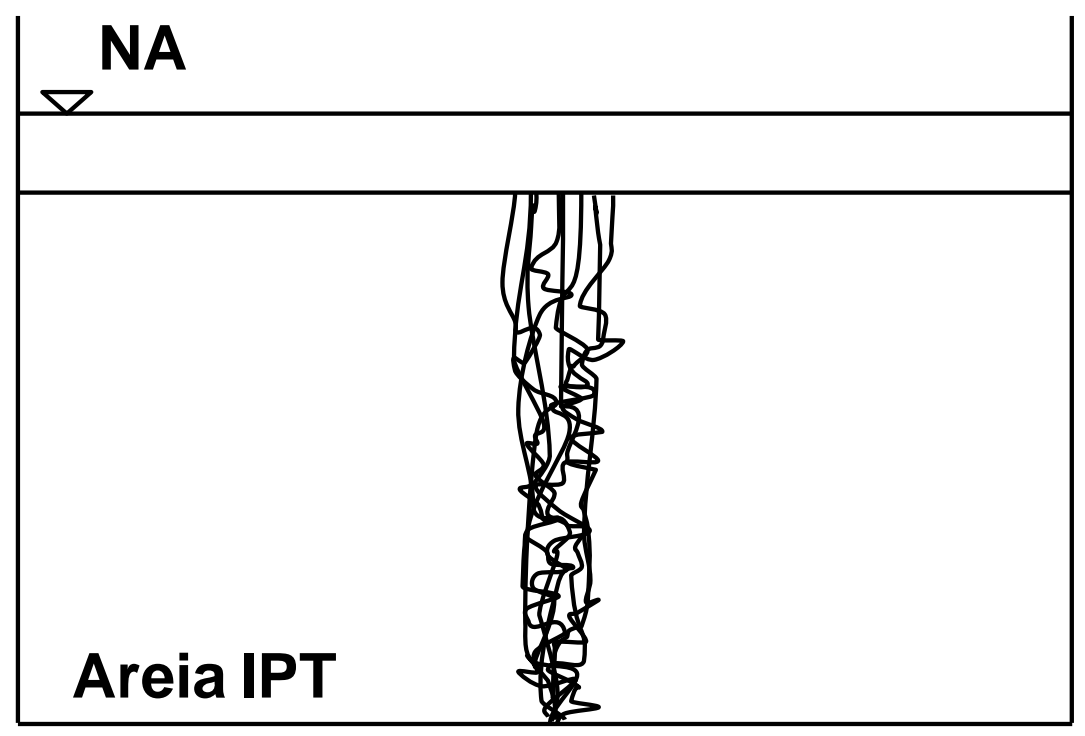

Figura 7.31 - Desenho esquemático do segundo e do terceiro ensaio com a Areia do IPT.

\subsubsection{Areia do IPT com lentes de baixa permeabilidade}

Para os ensaios com as lentes de baixa permeabilidade foi utilizada a Areia do IPT por se tratar de uma areia mais uniforme do que a Areia Osasco; evitando assim que os caminhos formados pelo ar encontrem camadas menos permeáveis na própria areia como foi visto no quinto ensaio com a Areia Osasco. As lentes de baixa permeabilidade foram feitas com um solo residual de gnaisse, silte arenoso, passado na peneira de $n^{\circ} 40$.

Foram realizados três ensaios com as lentes de baixa permeabilidade no modelo físico. A diferença entre o primeiro e o terceiro ensaio é o processo de montagem, sendo um com solo parcialmente saturado (primeiro) e outro com solo saturado (terceiro). E o segundo a diferença é a alta pressão de injeção. 
Tabela 7.10 - Descrição dos ensaios realizados com as lentes de baixa permeabilidade no modelo físico.

\begin{tabular}{|c|c|c|}
\hline Ensaio & Montagem & Comportamento do Fluxo \\
\hline 1 & $\begin{array}{l}\text { Solo parcialmente saturado e } \\
\text { saturação final por capilaridade. } \\
\text { Lentes de baixa permeabilidade com } \\
4 \mathrm{~cm} \text { de espessura. }\end{array}$ & $\begin{array}{l}\text { Região logo acima das lentes } \\
\text { não foi atingida pelo ar. }\end{array}$ \\
\hline 2 & $\begin{array}{l}\text { Mesma configuração do ensaio } 1 \mathrm{com} \\
\text { aumento gradativo da pressão de } \\
\text { injeção até } 50 \mathrm{kPa} \text {. }\end{array}$ & $\begin{array}{l}\text { Aumento do número de canais de } \\
\text { ar, mas a região logo acima das } \\
\text { lentes não foi atingida pelo ar. }\end{array}$ \\
\hline 3 & $\begin{array}{l}\text { Solo totalmente saturado e espessura } \\
\text { das lentes de baixa permeabilidade de } \\
2 \mathrm{~cm} \text {. }\end{array}$ & $\begin{array}{l}\text { A primeira lente de baixa } \\
\text { permeabilidade não ficou contínua } \\
\text { criando um caminho preferencial de } \\
\text { ar. }\end{array}$ \\
\hline 4 & $\begin{array}{l}\text { Mesma configuração do ensaio } 3 \text { com } \\
\text { aumento gradativo da pressão de } \\
\text { injeção até } 20 \mathrm{kPa}\end{array}$ & $\begin{array}{l}\text { Aumento do número de canais de } \\
\text { ar, mas a região logo acima das } \\
\text { lentes não foi atingida pelo ar. }\end{array}$ \\
\hline
\end{tabular}

A montagem do primeiro ensaio foi feita em cinco etapas. Primeiramente foi colocada uma pequena quantidade de água no tanque apenas para garantir a saturação da camada inicial de solo. A Areia do IPT foi depositada no tanque com um funil até uma altura de $20 \mathrm{~cm}$ como pode ser observada na Figura 7.32-(a); o nível d'água ficou abaixo da superfície da areia, ver Figura 7.32-(b), apenas para a execução da etapa seguinte. 
Capítulo 7 - Ensaios com o Modelo Físico Bidimensional em Laboratório
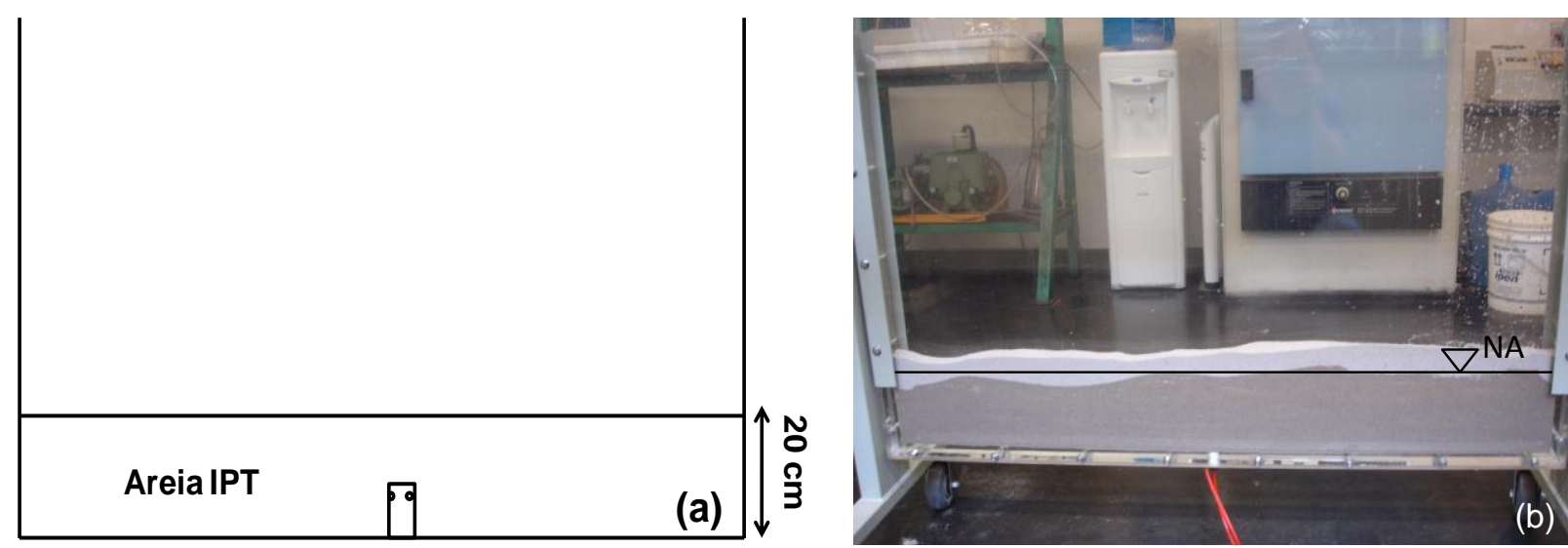

Figura 7.32 - Primeira etapa de montagem do ensaio com lentes de baixa permeabilidade. Em (a) desenho esquemático e em (b) foto da primeira camada de Areia do IPT.

Depois foram instaladas duas barras verticais feitas de PVC sobre a camada de areia, Figura 7.33-(b). Essas barras de PVC impediram que o solo residual, usado para compor as camadas de baixa permeabilidade, se espalhasse por toda a extensão do tanque, como mostra a Figura 7.33-(c). Com isso a primeira camada de baixa permeabilidade ficou com $50 \mathrm{~cm}$ de comprimento e $4 \mathrm{~cm}$ de altura; essa camada foi feita no centro do tanque. O solo residual foi inserido no tanque com auxilio do mesmo funil utilizado na etapa anterior e depois foi compactado. 
Capítulo 7 - Ensaios com o Modelo Físico Bidimensional em Laboratório
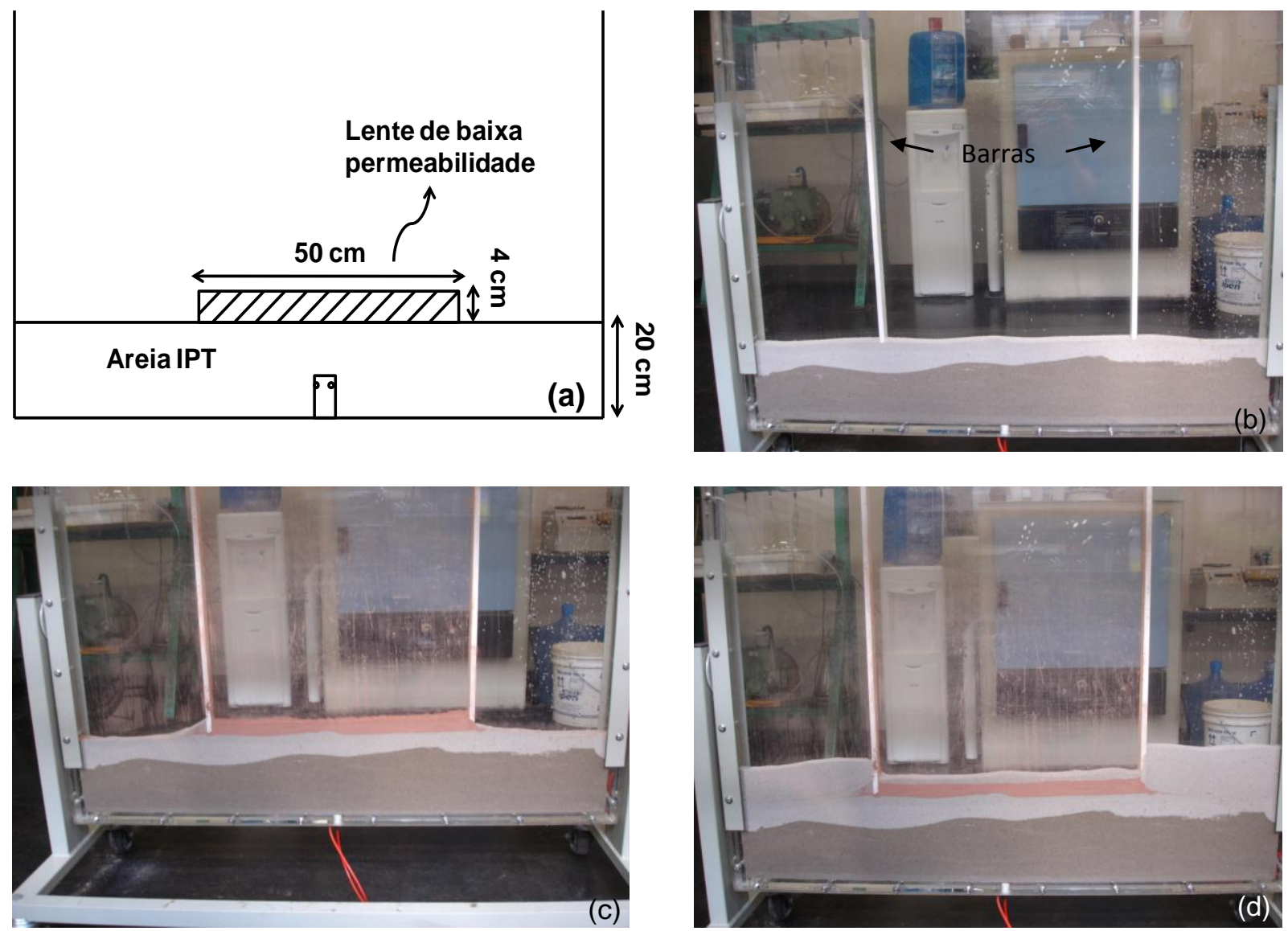

Figura 7.33 - Segunda etapa de montagem do primeiro ensaio com lentes de baixa permeabilidade. Em (a) desenho esquemático mostrando a primeira lente, em (b) colocação das barras de PVC, em (c) colocação do solo residual e em (d) colocação da areia nas laterais.

Após o término da primeira camada de solo residual as suas laterais foram preenchidas com areia, ver Figura 7.33-(d); as barreiras foram retiradas e foi colocado mais areia até uma altura de $13 \mathrm{~cm}$ a partir da base da camada de baixa permeabilidade. Na Figura 7.34 pode ser observada a primeira lente pronta entre as camadas de Areia do IPT. 

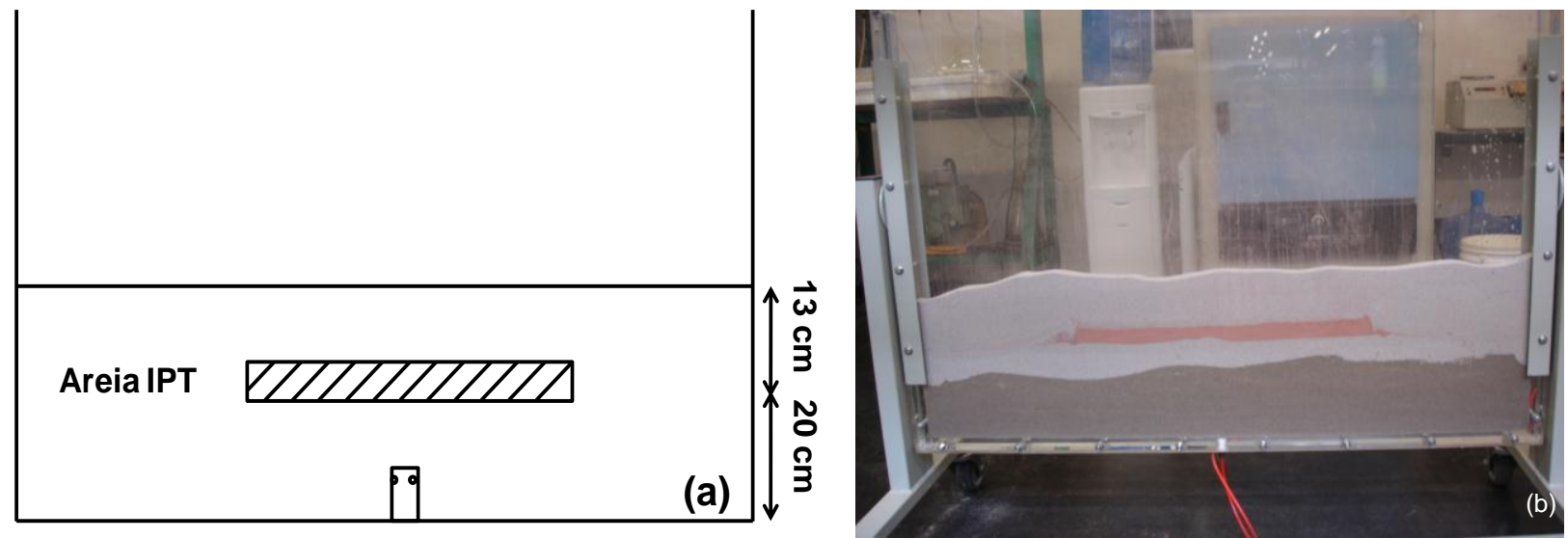

Figura 7.34 - Terceira etapa de montagem do primeiro ensaio com lentes de baixa permeabilidade. Em (a) desenho esquemático e em (b) foto da primeira lente entre as camadas de Areia do IPT.

Encerrada a execução da primeira lente foi dado início à saturação por capilaridade; no solo que já se encontrava no tanque. A quarta etapa de montagem se iniciou com a colocação das barras de madeira e deposição do material mais fino nos cantos do tanque, como pode ser notado na Figura 7.35-(b). Primeiro foram compactadas as lentes e depois foi colocado a areia entre as camadas de baixa permeabilidade e depois foram tiradas as barras. Essas camadas de solo residual ficaram com $45 \mathrm{~cm}$ de comprimento cada e $4 \mathrm{~cm}$ de altura.
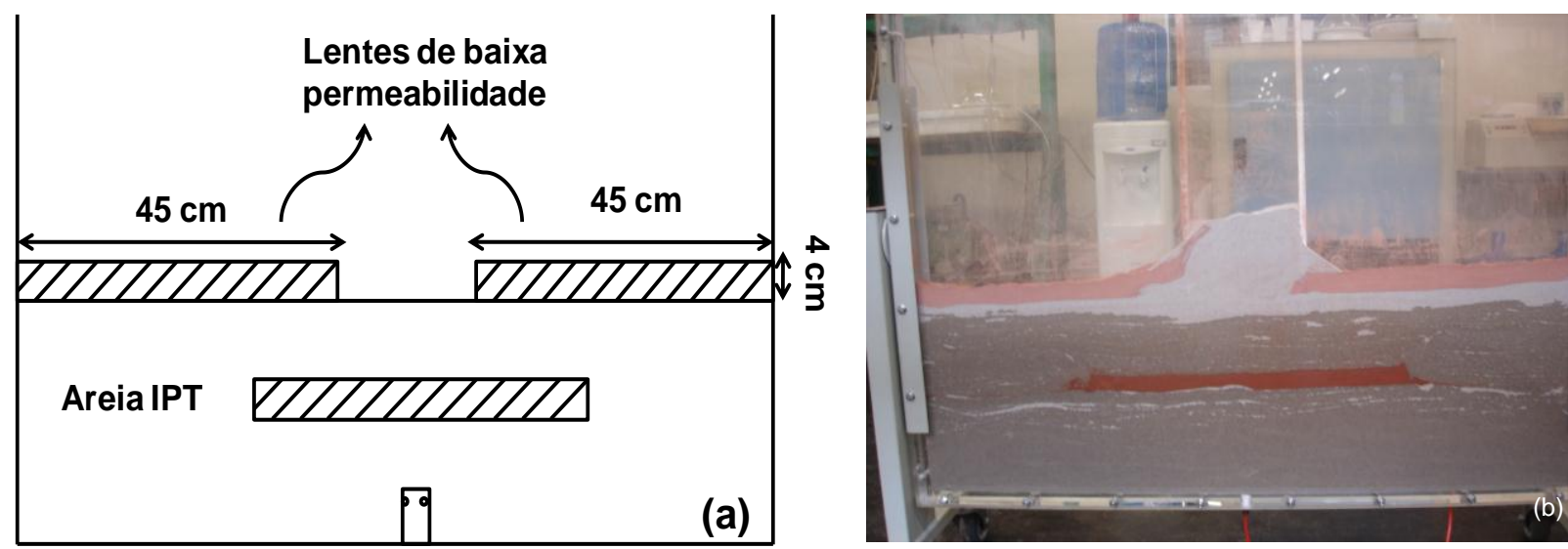

Figura 7.35 - Quarta etapa de montagem do ensaio com lentes de baixa permeabilidade. Em (a) desenho esquemático mostrando as três lentes e em (b) montagem da segunda barreira de lentes.

Terminada a compactação das lentes deu-se início a quinta e última etapa de montagem. O tanque foi completado com Areia do IPT até uma altura total de $57 \mathrm{~cm}$ como observado na Figura 7.36-(a). O índice de vazios da Areia do IPT neste ensaio 
foi de aproximadamente 0,86 assim como os ensaios realizados apenas com a Areia do IPT. No total foram colocados $26,5 \mathrm{~kg}$ de areia no tanque para a execução deste ensaio. Na Figura 7.36-(b) nota-se que o solo ainda não saturou completamente por capilaridade, a parte de solo mais clara logo acima da segunda barreira de lentes indica que a areia ainda não está saturada.
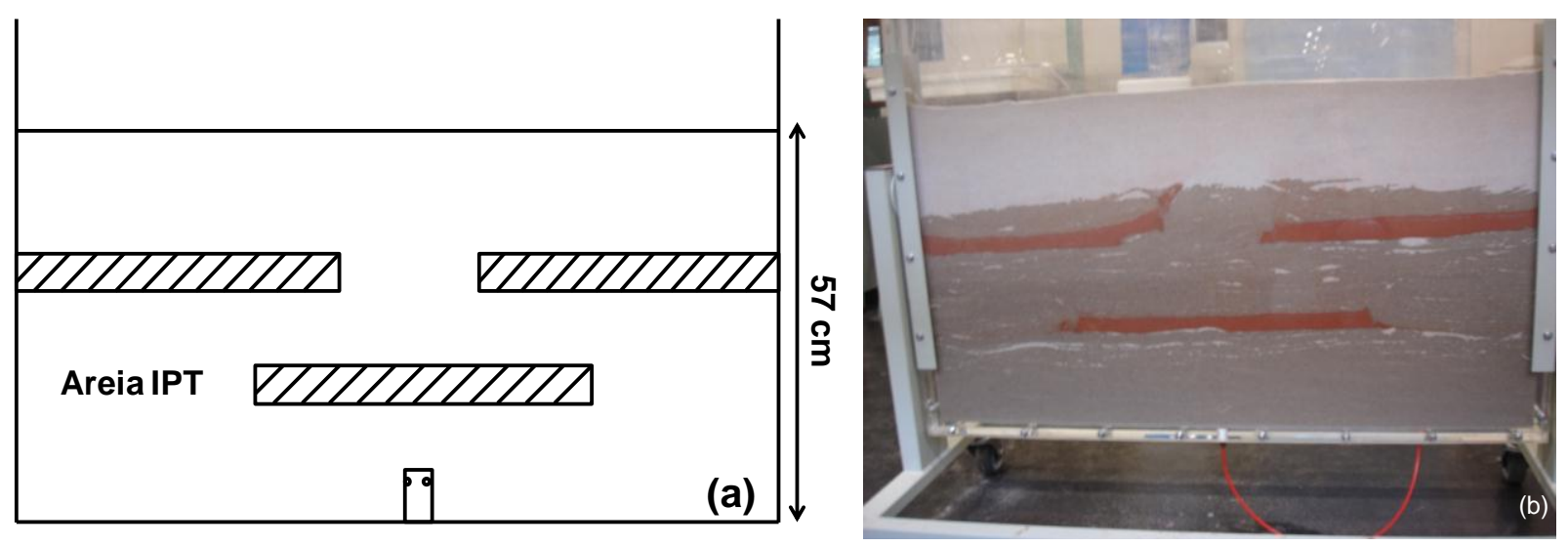

Figura 7.36 - Quinta etapa de montagem do ensaio com lentes de baixa permeabilidade. Em (a) desenho esquemático e em (b) montagem completa aguardando a saturação por capilaridade.

Depois do término da montagem do tanque o mesmo foi deixado uma semana com o objetivo de atingir a saturação da Areia do IPT e das lentes de baixa permeabilidade. A saturação não foi completa tendo permanecido regiões com bolhas de ar presas como pode ser notado na Figura 7.37.

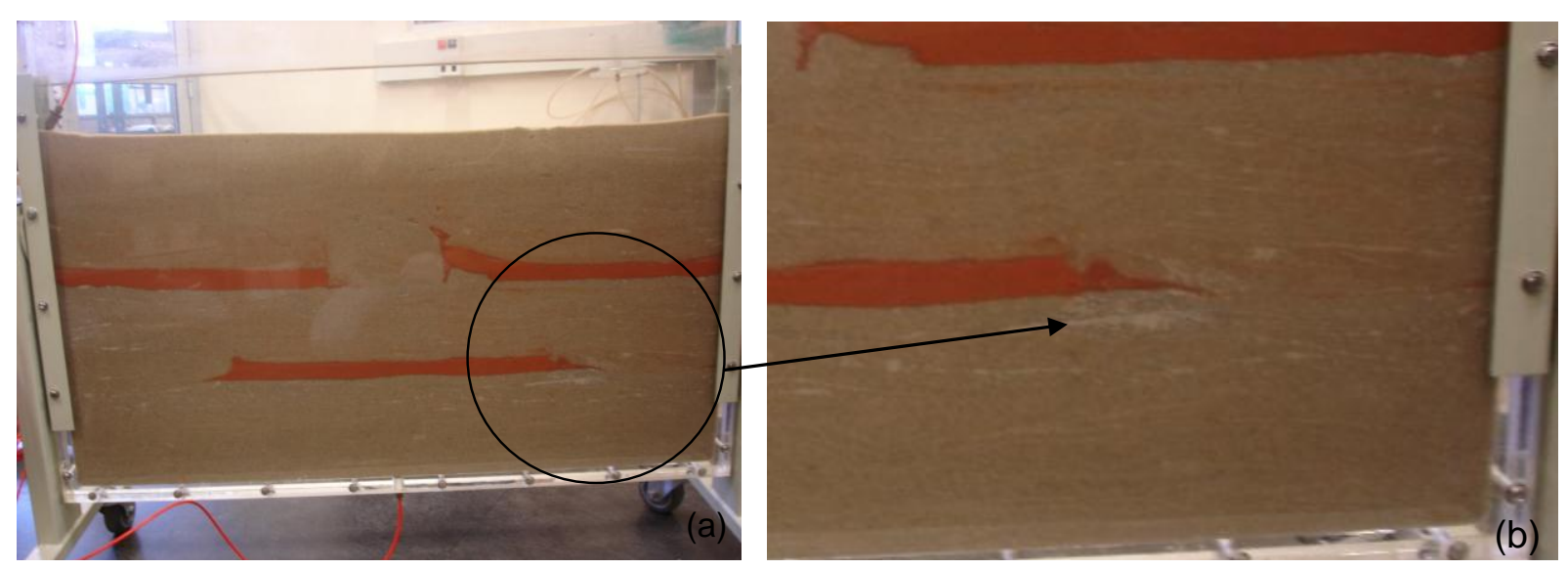

Figura 7.37 - Primeiro ensaio com as lentes de baixa permeabilidade. Em (a) arranjo após saturação antes da injeção de ar e em (b) detalhe da saturação incompleta.

As vazões medidas durante o primeiro ensaio com as lentes se encontram na Tabela 7.11. 
Tabela 7.11 - Medidas de injeção de ar e a vazão, primeiro ensaio com as lentes de baixa permeabilidade.

\begin{tabular}{cc}
\hline Pressão de injeção (kPa) & Vazão (L/s) \\
\hline 15 & 1,0 \\
17 & 2,0 \\
\hline
\end{tabular}

O primeiro ensaio foi realizado com o nível d'água $9 \mathrm{~cm}$ acima da superfície do solo. A entrada de ar ocorreu com uma pressão de $15 \mathrm{kPa}$. A injeção de ar foi feita no centro do tanque; o ar subiu até encontrar a primeira lente de solo residual, devido à baixa permeabilidade do material o ar se moveu lateralmente pelos dois lados do obstáculo. Após ultrapassar a primeira lente o ar continuou subindo até encontrar a segunda barreira, e se mover lateralmente até encontrar um caminho mais permeável e continuar subindo até a superfície, como pode ser percebido na Figura 7.38. A região mais clara percebida na Figura 7.38 corresponde a dessaturação do solo devido à passagem do ar.

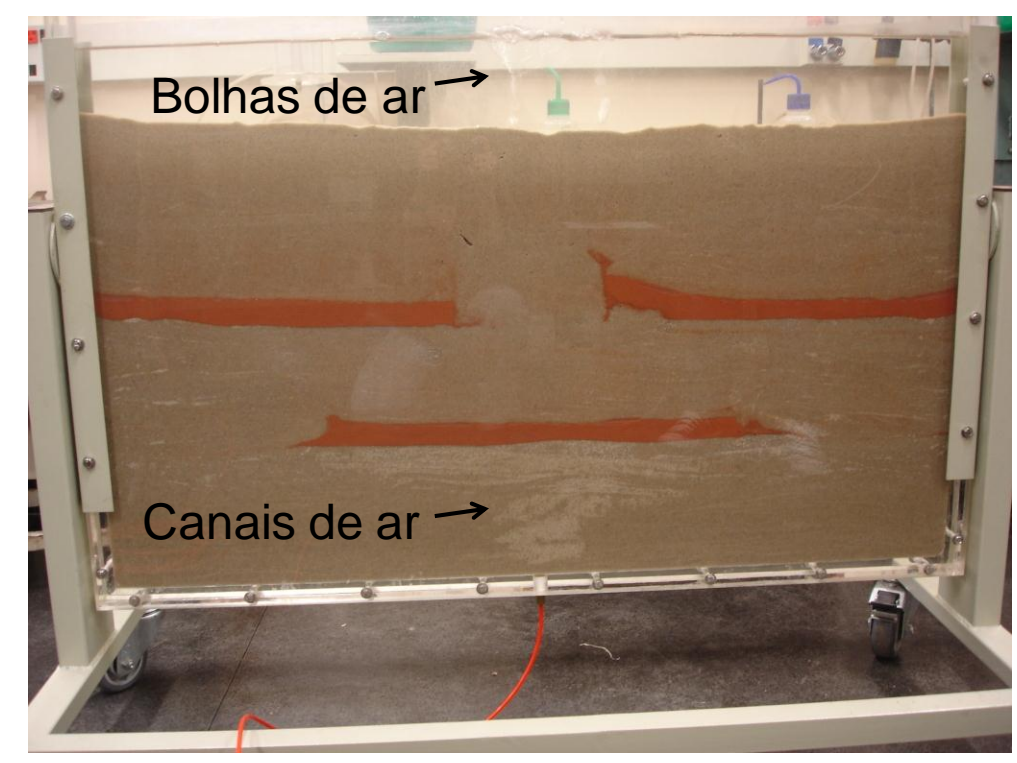

Figura 7.38 - Primeiro ensaio com as lentes de baixa permeabilidade, durante a injeção de ar.

A Figura 7.39 apresenta o desenho esquemático dos caminhos de ar formados durante a injeção de ar; nota-se também que a região logo acima das lentes não é atingida pelo ar, sendo este um dos motivos da ineficiência da aplicação do método de injeção de ar em solos que contenham lentes de baixa permeabilidade. 


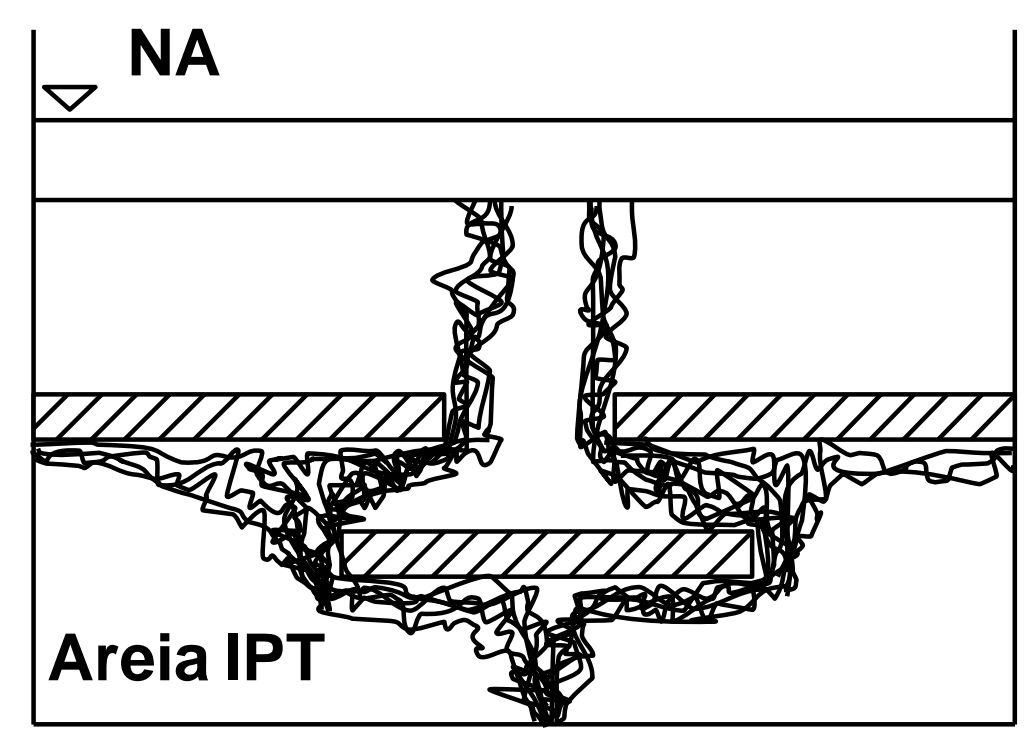

Figura 7.39 - Desenho esquemático mostrando o caminho percorrido pelo ar.

O segundo ensaio foi realizado logo após o término do primeiro sem que a injeção de ar fosse cessada, esse ensaio teve o aumento gradativo da pressão de injeção de $15 \mathrm{kPa}$ até $50 \mathrm{kPa}$, a Figura 7.40 mostra a foto durante a aplicação de uma pressão de $50 \mathrm{kPa}$. Nota-se pelo detalhe da figura que partículas de solos finos podem ser carregadas para cima junto com o ar pelos canais durante a injeção.

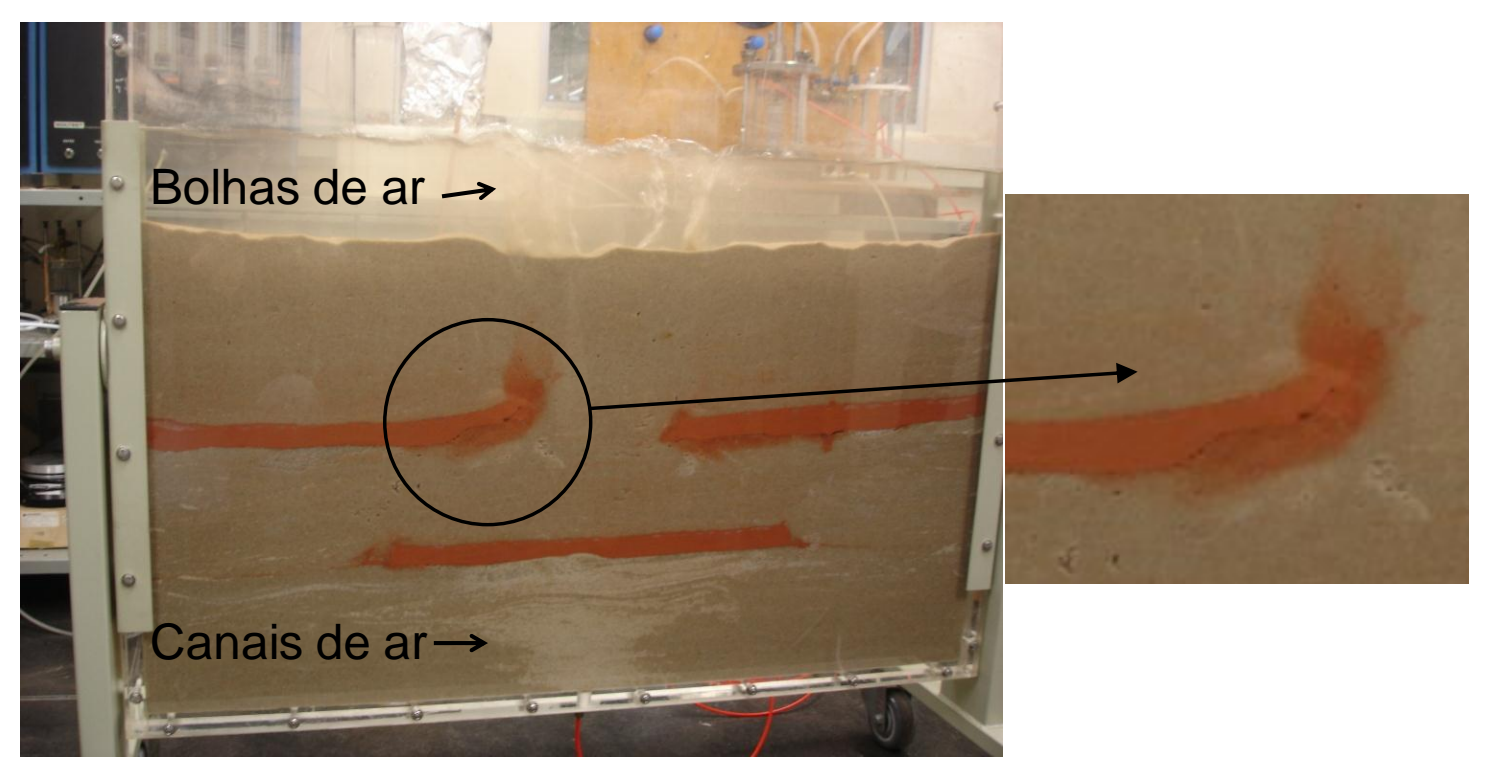

Figura 7.40 - Segundo ensaio com as lentes de baixa permeabilidade pressão de injeção de ar de $50 \mathrm{kPa}$.

Com o aumento da pressão de injeção mais canais de ar foram formados sendo que os canais existentes continuaram com o mesmo tamanho, houve apenas um 
aumento na zona de influência; a interpretação dos canais de ar formados pode ser observada na Figura 7.41. Os canais de ar não ultrapassaram as lentes de baixa permeabilidade porque a pressão de entrada de ar do solo residual não foi atingida e nem foram encontradas fraturas nas lentes. Neste ensaio as vazões não foram medidas.

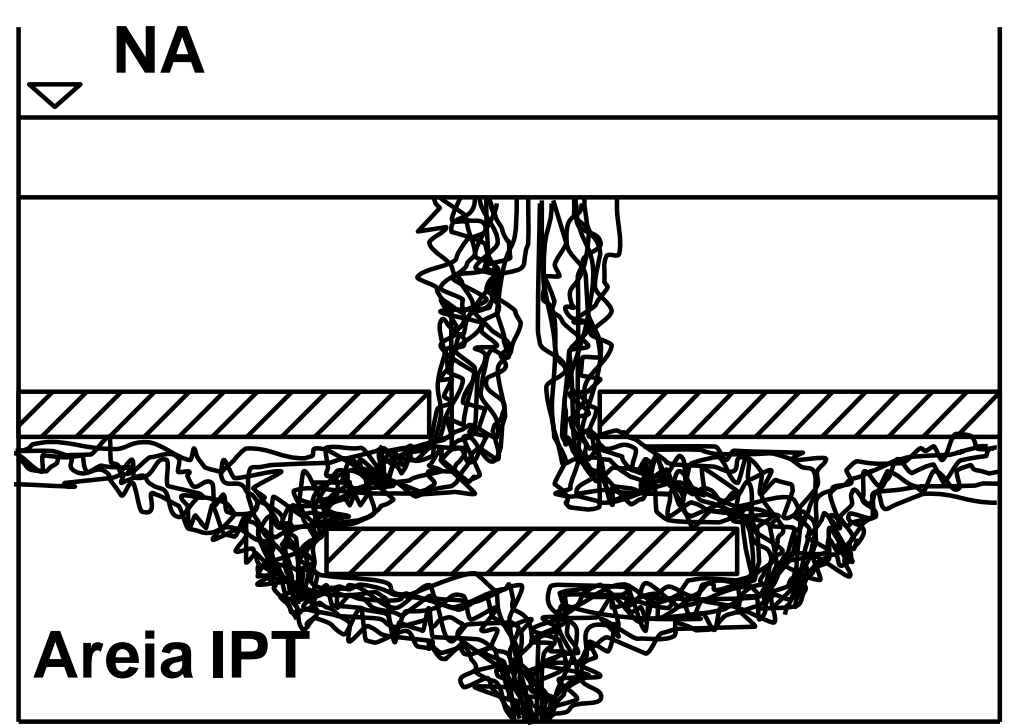

Figura 7.41 - Desenho esquemático mostrando os canais de ar formados durante o segundo ensaio com as lentes de baixa permeabilidade.

O terceiro ensaio com lentes de baixa permeabilidade foi realizado com o mesmo arranjo do primeiro, a diferença entre eles é a espessura das lentes que nesse ensaio é de $2 \mathrm{~cm}$ e o processo de montagem que foi realizado com solo saturado. Primeiramente foi colocado no tanque a Areia do IPT até uma altura de $20 \mathrm{~cm}$ e com o nível d'água acima da superfície foi feita a primeira lente de baixa permeabilidade com as dimensões de $50 \mathrm{~cm}$ de comprimento e $2 \mathrm{~cm}$ de espessuras como mostra a Figura 7.42-(a). Na Figura 7.42-(b) pode ser observado que o nível d'água ficou acima da superfície durante a montagem da primeira lente. 
Capítulo 7 - Ensaios com o Modelo Físico Bidimensional em Laboratório
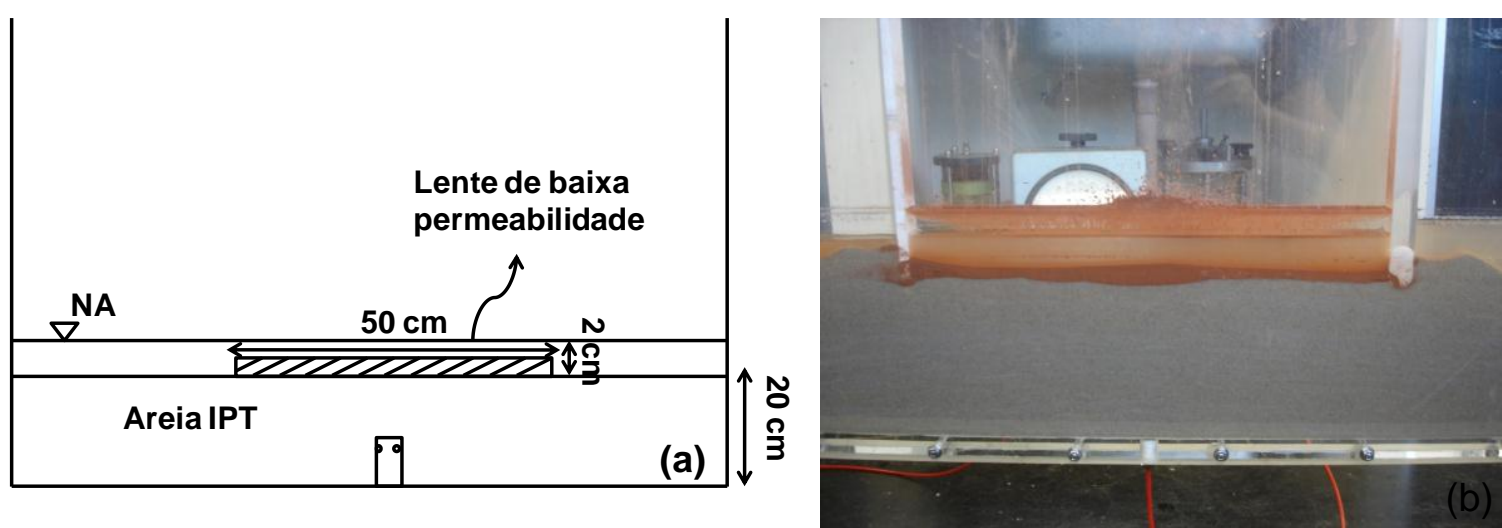

Figura 7.42 - Primeira e segunda etapas da segunda montagem do tanque com lentes de baixa permeabilidade. Em (a) desenho esquemático e em (b) montagem da primeira lente.

Antes de dar início a terceira etapa da montagem esperou-se o silte, material da lente de baixa permeabilidade, sedimentar. Depois foram inseridos mais $13 \mathrm{~cm}$ da Areia do IPT como está representado na Figura 7.43-(a). Na Figura 7.43-(b) pode ser visto o início da colocação da Areia do IPT no tanque; a Figura 7.43-(c) mostra o tanque logo após a retirada das barras que auxiliaram a execução da lente de baixa permeabilidade e em (d) tem-se o fim da terceira etapa.
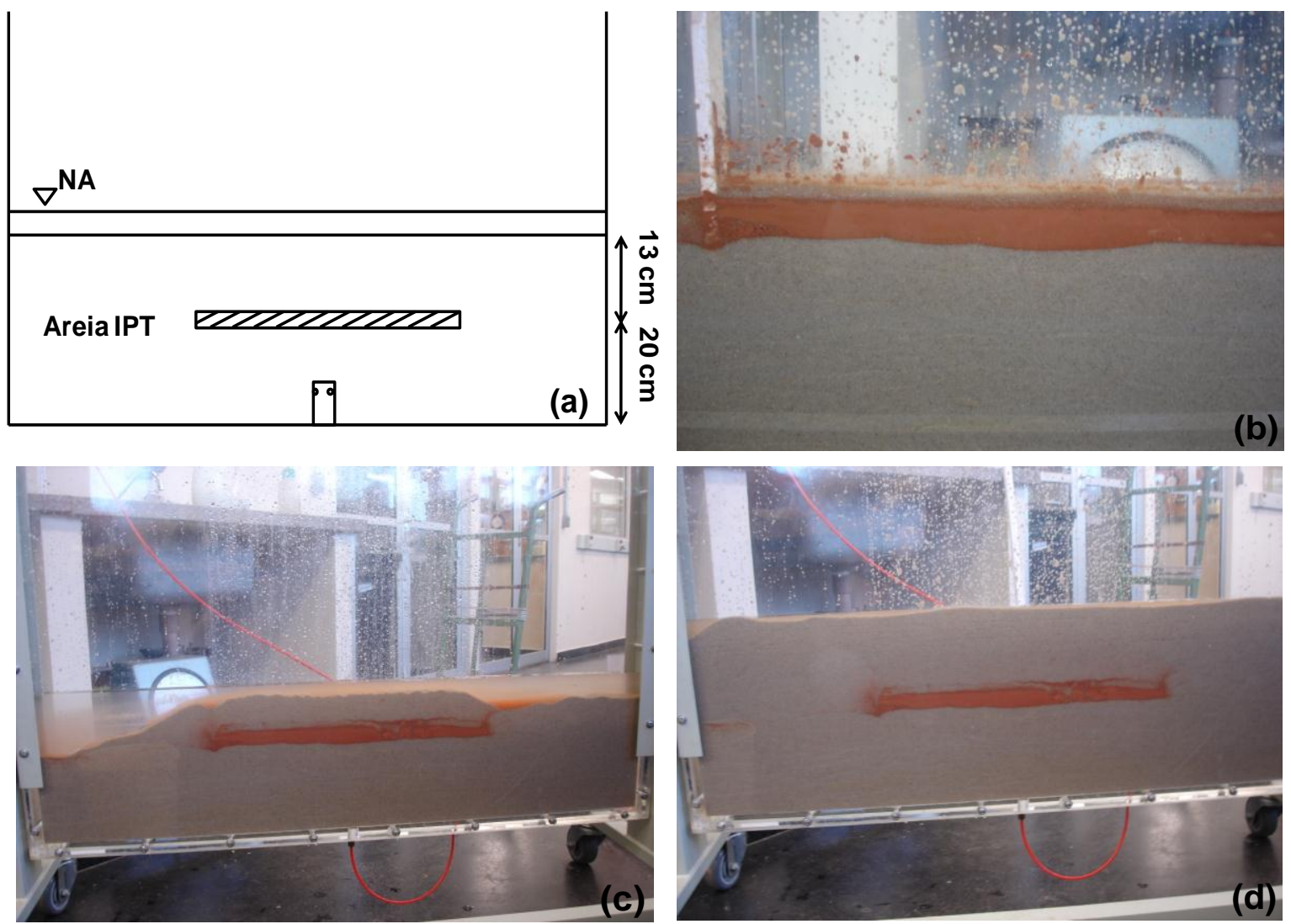

Figura 7.43 - Terceira etapa de montagem. Em (a) desenho esquemático, em (b) colocação do silte, (c) colocação da areia sobre a primeira lente e (d) colocação dos $13 \mathrm{~cm}$ de areia. 
$\mathrm{Na}$ quarta etapa foram feitas mais duas lentes de baixa permeabilidade de $45 \mathrm{~cm}$ de comprimento e $2 \mathrm{~cm}$ de espessura com pode ser observado na Figura 7.44-(a) e na Figura 7.44-(b). Assim como no final da execução da primeira lente esperou-se o silte sedimentar antes de se iniciar a quinta etapa, a Figura 7.44-(c) mostra o tanque antes da sedimentação das lentes. Durante a quinta etapa foi inserido no tanque 21 $\mathrm{cm}$ de areia sobre as lentes, a Figura 7.44-(d) mostra a execução desta última etapa.
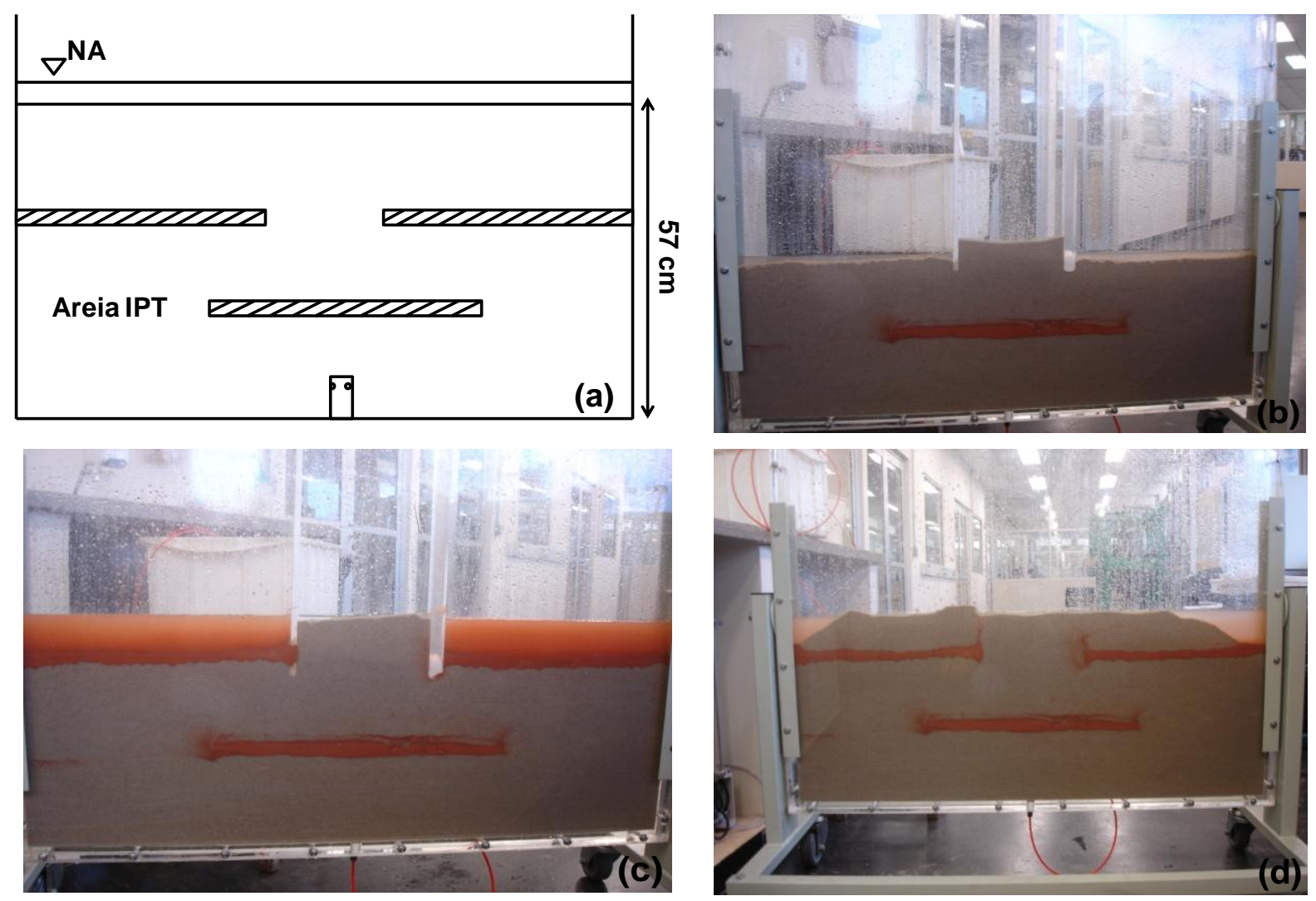

Figura 7.44 - Quarta e quinta etapas de montagem do tanque com lentes. Em (a) desenho esquemático, em (b) colocação da areia no centro entre as lentes, (c) colocação do silte para a formação das lentes e (d) colocação da areia sobre as lentes.

Foram usados $26,05 \mathrm{Kg}$ de Areia do IPT na montagem do terceiro ensaio com as lentes de baixa permeabilidade. Após o término da preparação do tanque esperouse uma semana até a realização dos ensaios, para que o solo fino adensasse. $O$ nível d'água encontrava-se $5 \mathrm{~cm}$ acima da superfície do solo durante os ensaios. $\mathrm{Na}$ Figura 7.45 pode ser observado o tanque antes do início do ensaio. Devido à montagem ter sido feita inteiramente com o solo saturado percebe-se que não houve partes do solo que ficaram dessaturadas como ocorreu no primeiro ensaio. 


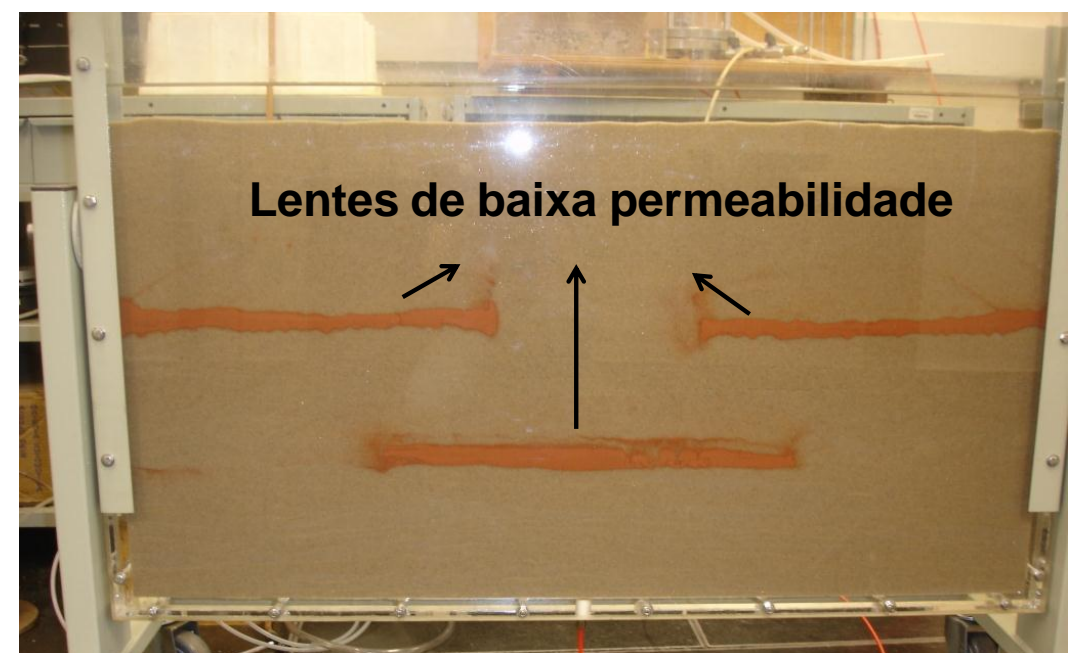

Figura 7.45 - Tanque antes do terceiro ensaio com as lentes de baixa permeabilidade.

A pressão de injeção foi aumentada gradativamente até $13 \mathrm{kPa}$ a partir da qual o ar começou a entrar no solo. A vazão medida para esta pressão foi de 1,6 L/s. Assim como no primeiro ensaio com as lentes neste terceiro ensaio o ar também subiu verticalmente até encontrar a primeira lente e depois se moveu lateralmente devido a alta permeabilidade horizontal. Após passar por esta lente o ar continuou a subir verticalmente até encontrar a segunda barreira; onde o ar se moveu lateralmente no contato entre as lentes e a areia até encontrar um caminho vertical mais permeável e subir até a superfície como mostra a Figura 7.46.

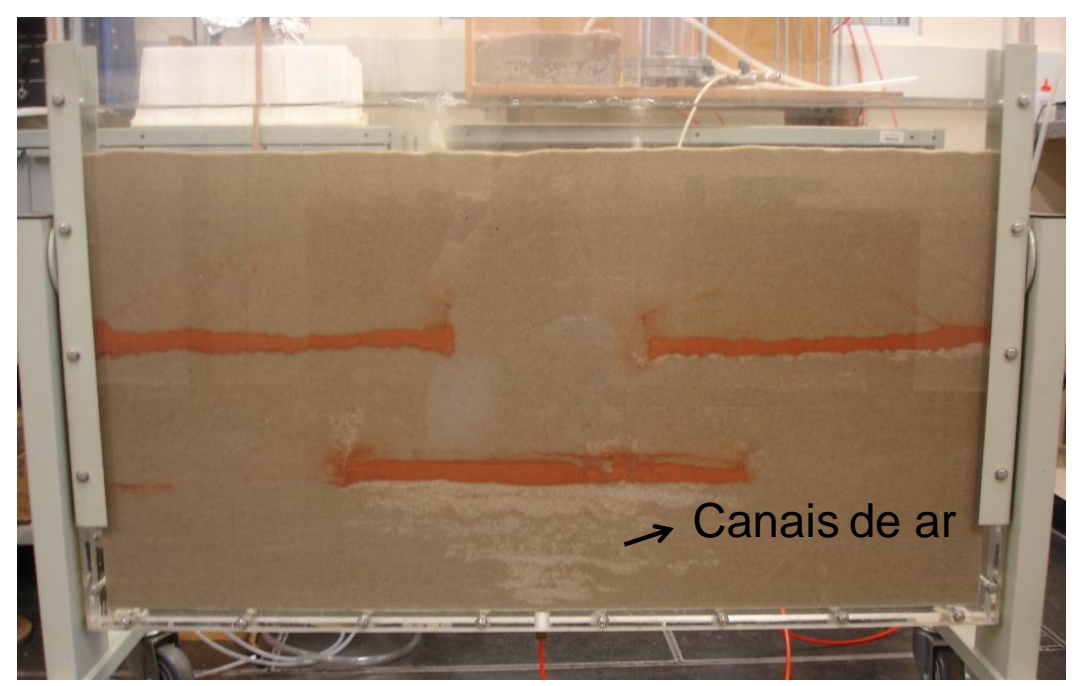

Figura 7.46 - Terceiro ensaio de injeção de ar com lentes de baixa permeabilidade, nota-se os canais de ar formados. 
A primeira lente de baixa permeabilidade não ficou contínua como pode ser observado na Figura 7.47-(a), durante sua execução algumas imperfeições não conseguiram ser corrigidas, essa descontinuidade criou um caminho preferencial para o ar como mostra a Figura 7.47-(b).
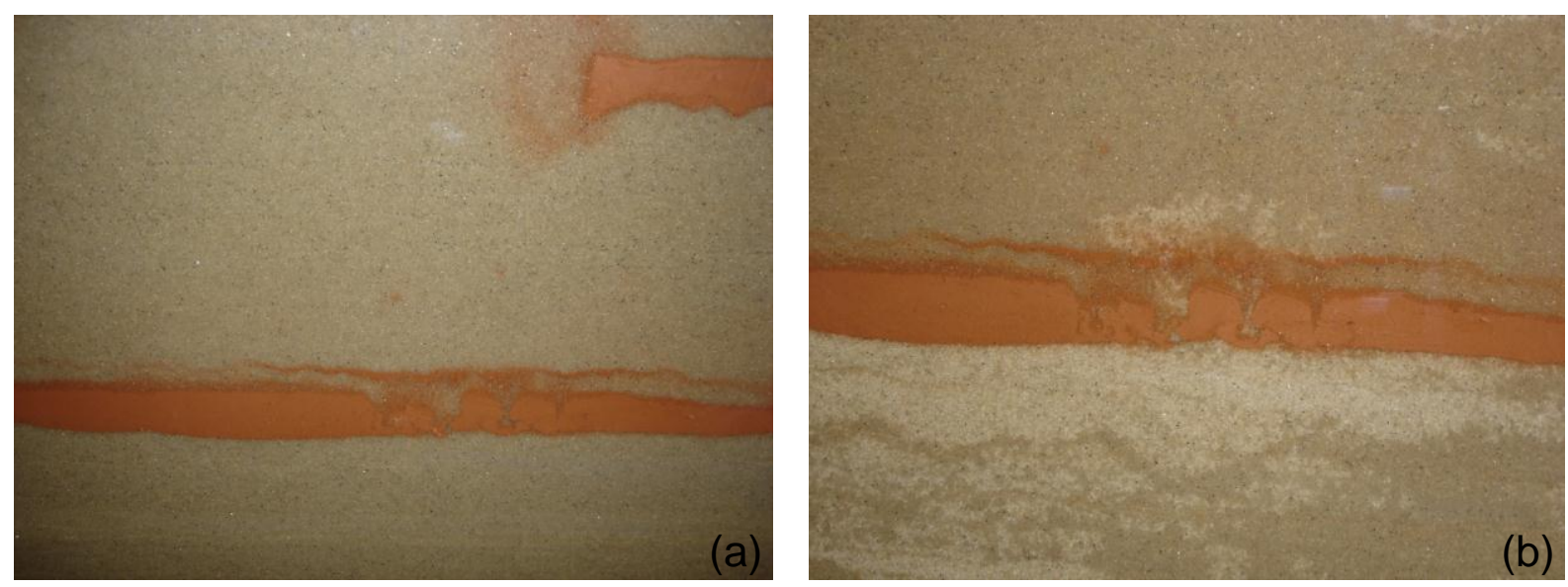

Figura 7.47 - (a) detalhe da não uniformidade da primeira lente de baixa permeabilidade antes da injeção de ar e em (b) após injeção.

A Figura 7.48 apresenta o desenho esquemático da interpretação dos caminhos de ar formados durante a injeção. Devido a não uniformidade da primeira lente parte do ar passou por ela e outra parte contornou a lente. Também é possível notar que a região logo acima da segunda barreira de lentes não foi alcançada pelo ar. E é por esse motivo que a presença de lentes de baixa permeabilidade causa uma ineficiência do método de injeção de ar em campo, pois essa região não seria remediada. 


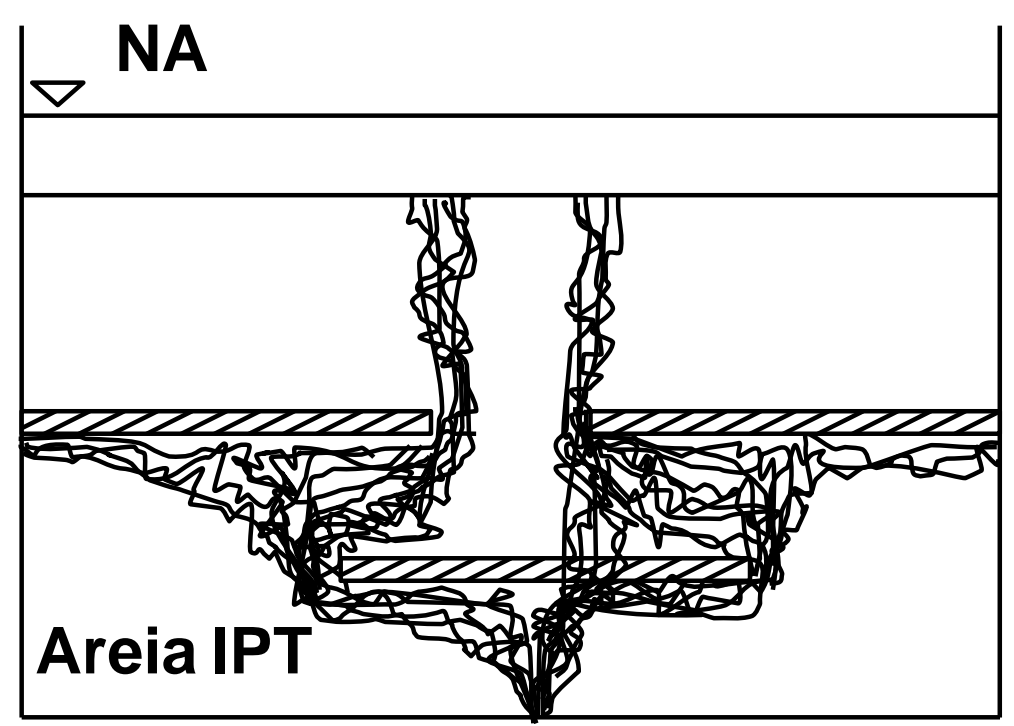

Figura 7.48 - Desenho esquemático mostrando os caminhos percorridos pelo ar.

Por causa da baixa permeabilidade e da alta entrada de ar das lentes o ar prefere se mover lateralmente pelo contato lente/areia do que subir verticalmente passando pelo silte. A Figura 7.49 mostra o detalhe do ar passando pelo contato entre os solos; em (a) o ar fez com que a lente subisse se descolando da areia e em (b) pode ser visto o ar através da dessaturação de uma pequena região logo abaixo da lente.
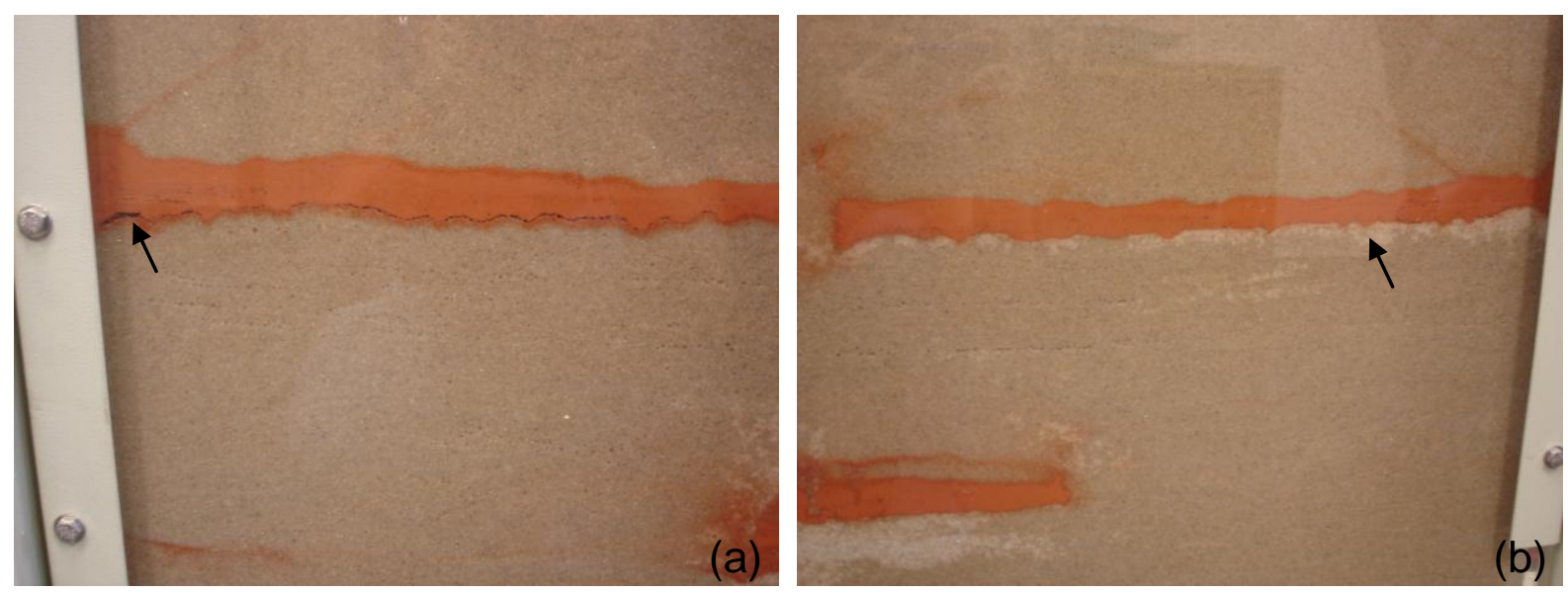

Figura 7.49 - Detalhe da passagem de ar no contato entre o silte e a areia em (a) lado esquerdo e em (b) lado direito do tanque.

Após o término do terceiro ensaio um quarto ensaio foi realizado com o mesmo arranjo apenas aumentando gradativamente a pressão de injeção até 20 kPa (vazão de 3,0 L/s) e assim como no segundo ensaio houve um aumento da zona de influência principalmente perto do ponto de injeção de ar. Na Figura 7.50 podem ser 
observados os canais de ar durante a injeção de $20 \mathrm{kPa}$ e o aumento da zona de influência.

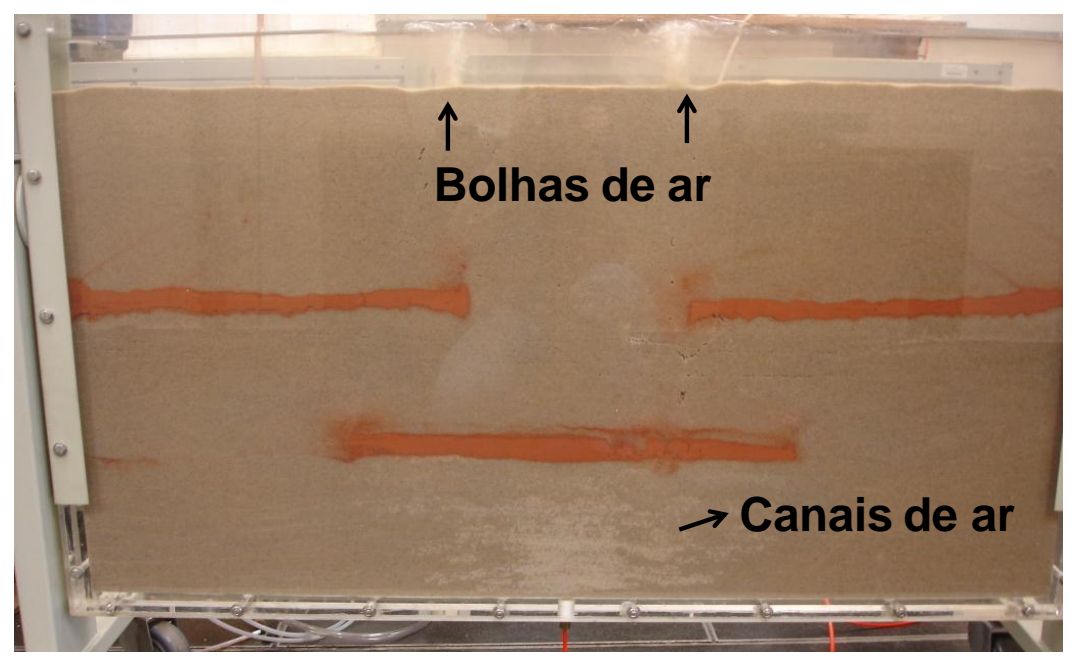

Figura 7.50 - Foto do ensaio com $20 \mathrm{kPa}$.

Na Figura 7.51 pode ser visto o detalhe da passagem de ar pela descontinuidade da primeira lente de silte. Cabe salientar que uma pequena abertura na lente de baixa permeabilidade já é suficiente para a passagem de uma parte do ar.

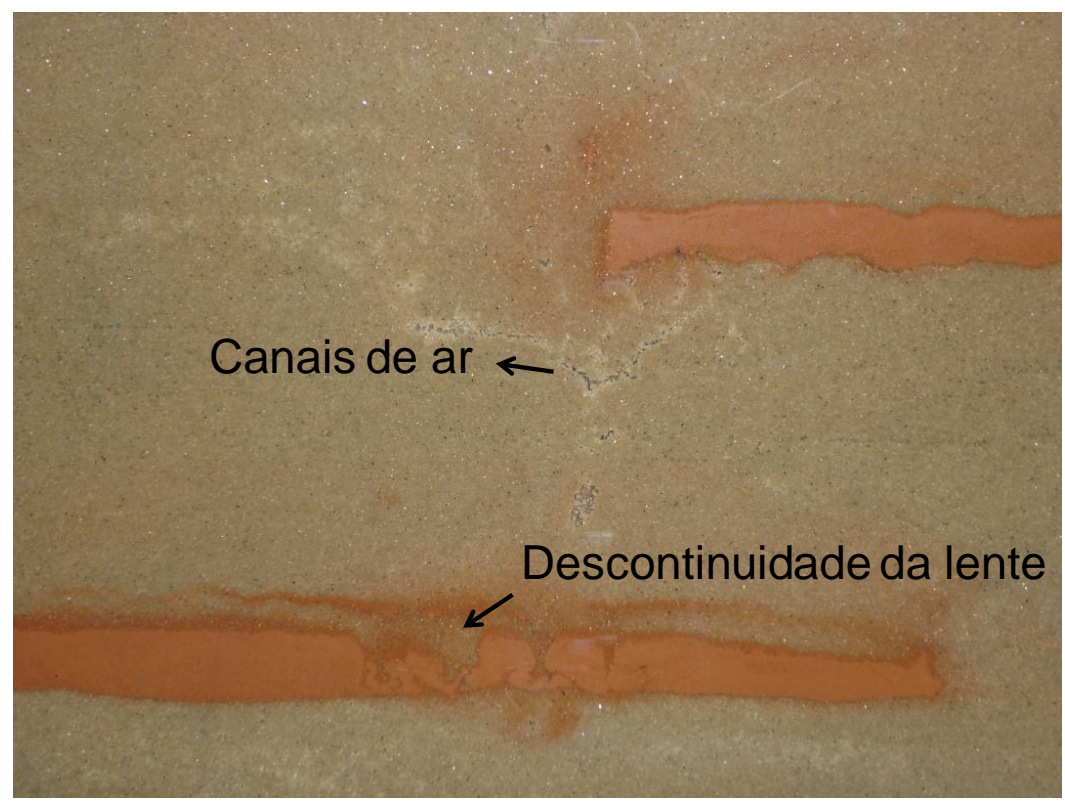

Figura 7.51 - Detalhe dos canais de ar passando pela primeira lente de baixa permeabilidade. 


\section{Capítulo 8}

\section{Conclusões e Recomendações}

Com base na literatura notou-se que o método de descontaminação de solos e águas subterrâneas através da injeção de ar é mais indicado para solos grossos (areias e cascalhos). A região de solo atingida pelo fluxo de ar é denominada de zona de influência. É nela que ocorre a volatilização dos contaminantes e por conta disso a descontaminação do solo está diretamente ligada ao tamanho e formato da zona de influência. A permeabilidade, estrutura do solo, granulometria e homogeneidade são as principais condicionantes da descontaminação através desse método.

\section{Influência do tipo de solo}

O único tipo de fluxo de ar encontrado nos ensaios foi o de canais de ar discreto (ou simplesmente canais de ar). O formato da zona de influência encontrado para a Areia Osasco foi parabólico com ápice no ponto de injeção, já para a Areia do IPT que é um material de granulometria uniforme a zona de influência foi bem menor, o fluxo foi quase vertical saindo do ponto de injeção. A Areia do IPT é mais permeável

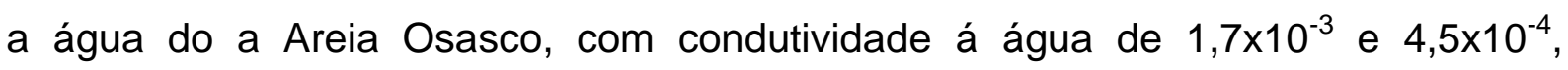
respectivamente. A porosidade da Areia Osasco $(n=0,39)$ é menor do que a da Areia do IPT $(n=0,46)$ isso pode explicar a expansão lateral da primeira areia; quanto menor a porosidade maior a tortuosidade do solo e quanto maior a tortuosidade maior a expansão lateral. Devido à estreita área afetada pelo ar nos ensaios com a Areia do IPT para o tratamento desse solo em campo seria necessária a instalação de vários poços de injeção de ar para se atingir a remoção desejada dos contaminantes. 


\section{$\underline{\text { Heterogeneidade }}$}

Pode-se notar através de ensaios com o modelo bidimensional que a heterogeneidade influenciou o formato da zona de influência. Os ensaios com a Areia Osasco mostraram uma zona de influência não simétrica devido à heterogeneidade do solo. Já os ensaios com a Areia do IPT apresentaram uma zona de influência simétrica em relação ao ponto de injeção por causa da uniformidade do solo.

A sedimentação das areia durante a montagem dos ensaios formou camadas de material mais fino sobre material mais grosso o que causou um aprisionamento de bolhas de ar nas camadas de material mais fino, as bolhas de ar só romperam quando a entrada de ar dessas camadas finas foi superada; mostrando assim que a injeção de ar em solos finos pode causar algumas situações indesejáveis.

\section{Lentes de Baixa Permeabilidade}

As lentes de baixa permeabilidade direcionam o fluxo de ar, pois devido à alta pressão de entrada de ar do material das lentes o ar prefere se mover lateralmente pela areia contornando a lente. No segundo ensaio com as lentes ocorreu uma descontinuidade da primeira lente durante a montagem do tanque isso mostrou que um pequeno caminho de alta permeabilidade já faz com que o ar passe pela lente.

Pode-se notar que durante os ensaios no modelo bidimensional com as lentes de baixa permeabilidade a região logo acima delas não foi atingida pelo ar, se tornando assim um dos motivos da ineficiência da aplicação da técnica de injeção de ar em locais com presenças de camadas de baixa permeabilidade, mesmo que as camadas tenham pequenas espessuras.

\section{Modelo Físico Bidimensional}

Foi realizado apenas um ensaio para a verificação do comportamento do fluxo (expansão, colapso e equilíbrio) que mostrou que a zona de influência cresce atinge 
Capítulo 8 - Conclusões e Recomendações

seu ápice e depois de um período de aproximadamente 1 hora, para a Areia Osasco, a zona de influência diminui de tamanho e atinge um equilíbrio.

Notou-se que o aumento da pressão de injeção de ar criou novos canais de ar sem aumentar o tamanho dos canais existentes. Com isso há um aumento da zona de influência e da densidade de canais de ar no solo, melhorando o desempenho do método.

Também foi percebido que em alguns ensaios houve a formação de ramos mortos que são canais de ar que não atingem a zona não saturada se tornando, portanto ineficazes na descontaminação do solo.

\section{Ensaios de Laboratório}

Os ensaios de laboratório permitiram a determinação da variação da condutividade ao ar em função do grau de saturação para diversas pressões de injeção de ar. O aumento da pressão de injeção induz a saída de água da amostra o que impede o aumento desta pressão para elevados valores de grau de saturação.

Foi possível determinar o valor da permeabilidade intrínseca para as duas areias testadas; sendo que os valores obtidos foram da ordem de $10^{-12}$ tanto para a Areia Osasco como para a Areia do IPT.

Observou-se uma pequena tendência de variação da permeabilidade com o grau de saturação. No caso da Areia do IPT esta tendência desaparece para pressões elevadas. Quanto mais saturado o corpo de prova estiver menor é a permeabilidade ao ar, pois o ar tem maior dificuldade de passar já que os poros do solo estão preenchidos com água.

\subsection{Recomendações para estudos posteriores}

Deveriam ser feitos estudos no modelo físico bidimensional com as mesmas areias utilizadas neste trabalho contaminadas com Compostos Orgânicos Voláteis (VOC's) para a comparação da zona de influência, verificando se há mudança no formato e 
tamanho da região afetada pelo ar e na densidade dos canais devido à presença do contaminante. Também devem ser feitos monitoramentos no tanque durante a injeção de ar para verificar a eficiência de remoção dos contaminantes.

Seria interessante realizar estudos com solos no tanque com zona não saturada para verificar o efeito da biodegradação durante a injeção de ar e o comportamento dos canais de ar formados.

O efeito de expansão e colapso da zona de influência foi pouco abordado neste trabalho, poderiam ser feitos ensaios que representassem melhor esse fenômeno. Assim como estudos da injeção de ar por pulso no modelo físico. Os ensaios realizados foram de curta duração deveriam ser feitos novos ensaios com duração de até 24 horas para observar a mudança na zona de influência formada.

No presente estudo foram realizados apenas ensaios com materiais de $D_{50}$ de aproximadamente $0,5 \mathrm{~mm}$ sendo que a geometria do fluxo encontrada foi por canais de ar, seria interessante verificar a geometria do fluxo de ar para solos com $D_{50}$ maiores do que $2 \mathrm{~mm}$ que segundo alguns autores o fluxo encontrado é por bolhas.

Seria interessante fazer um estudo no modelo bidimensional com uma camada de Areia do IPT (uns $30 \mathrm{~cm}$ ) e acima dela uma camada de Areia Osasco (também uns $30 \mathrm{~cm}$ ) para verificar se ocorre o espalhamento da zona de influência quando o ar alcança a segunda Areia.

No presente trabalho foram medidas as vazões de entrada de ar. Deveria ser medida também a vazão de saída de ar no tanque. 


\section{Capítulo 9}

\section{Referências Bibliográficas}

ADAMS, J. A.; REDDY, K. R., The effect size distribution on air sparging efficiency. In: Alleman, B. C., Lesson A. (eds) In situ and on-site bioremediation, vol 1. Battelle Press, Columbus, Ohio, p. 165-172, 1997.

ABBAS, A.; CARCASSES, M.; OLLIVIER J. P. Gas permeability of concrete in relation to its degree of saturation. Materials and Structures, vol 32, p. 3-8, 1999.

AHLFELD, D. P.; DAHMANI, A.;JI W. A Conceptual Model of Field Behavior of Air Sparging and Its Implications for Application. Groundwater Monitoring and Remediation, Fall, p. 132-139, 1994.

AIVALIOTI, M. V.; GIDARAKOS, E. L. In-well air sparging efficiency in remediating the aquifer of a petroleum refinery site. Environmental Engineering Science, p. 71-82, 2008.

ASSOCIAÇÃO BRASILEIRA DE NORMAS TÉCNICAS. NBR 6502: Rochas e solos: terminologia. Rio de Janeiro, 1995. 18p.

NBR 6508: Grãos de solos que passam na peneira de $4,8 \mathrm{~mm}-$ Determinação da massa específica. Rio de Janeiro, 1984. 8p.

NBR 7181: Solo - Análise granulométrica. Rio de Janeiro, 1984. 13 p. (Versão Corrigida: 1988).

NBR 12004: Solo - Determinação do índice de vazios máximo de solos não coesivos - Método de ensaio. Rio de Janeiro, 1990. 6 p.

NBR 12051: Solo - Determinação do índice de vazios mínimo de solos não coesivos - Método de ensaio. Rio de Janeiro, 1991. 15 p.

NBR 13292: Solo - Derteminação do coeficiente de permeabilidade de solos granulares à carga constante - Método de ensaio. Rio de Janeiro, 1995. $8 p$.

BAKER, D. Physical modeling of in situ air sparging. MS Thesis, University of Wisconsin-Madison, 1996.

BAKER, D. M.; BENSON C. H. Effect of system variables and particle size on physical characteristics of air sparging plumes. Geotechnical Geological Engenering, p. 543-558, 2007. 
remediation (Proceedings of the specialty conference held in conjunction with the ASCE National Convention) November 12-24,. Washington, D.C,: ASCE, p. 292-310, 1996.

BOUAZZA, ABDELMALEK, e THAVEESAK VANGPAISAL. An apparatus to measure gas permeability of geosynthetic clay liners. Geotextiles and Geomembranes, p. 85-101, 2003.

BROOKS, R. H.; COREY A. T. Hidraulic properties of porous media. Hydrological Paper. Vol 3, Coloraso State University, 1964.

BROOKS, M. C.; WISE, W. R .; ANNABLE, M. D. Fundamental changes in "in situ" air sparging flow patterns. Ground Water Monitoring Remediation, p. 105$113,1999$.

CETESB- GTZ (1999). Manual de Gerenciamento de Áreas Contaminadas Projeto CETESB - GTZ - Cooperação Técnica Brasil - Alemanha

CHAO, K.; ONG, S. K.; HUANG, M. Mass transfer of VOCs in laboratory-scale air sparging tank. Journal of Hazardous Materials, p. 1098-1107, 2008.

CLAYTON, W. S. A Field and Laboratory Investigation of Air Fingering During Air Sparging. Ground Water Monitoring Review, Summer, p. 134-145, 1998.

ELDER, C. R.; BENSON, C. H. Air Channel Formation, Size, Spacing, and Tortuosity During Air Sparging. Ground Water Monitoring Review, Summer, p. 171-181, 1999.

EPA 542-B-97-010, WASTECH. Innovative site remediation technology - Volume 7 - Vacuum Extration and Air Sparging. Monografia, American Academy of Environmental Engineers under a cooperative agreement with the U.S. Environmental Protection Agency, Maio, 1994.

EPA 510-R-96-001. How to effectively recover free produtc at leaking underground storage tank sites - A guide for state regulators. Washington, September, 1996.

FINOTTI, A. R.; CAICEDO, N. O. L.; RODRIGUEZ, M. T. R. Contaminações subterrâneas com combustíveis derivados de petróleo: toxidade e a legislação brasileira. Revista Brasileira de Recursos Hídricos, p. 29-46, 2001.

GUDEMANN, H. e HILLER, D. In situ remediation of VOC contaminated soil and ground water by vapor extraction and ground water aeration. Proccedings of the Third Annual Hazetech International Conference, Cleveland, 1988.

IGNATIUS, S. G.. Fluxo unidimensional de gás através de um solo compactado - Determinação laboratorial dos parâmetros. 1999, 337 PGS. Tese (Doutorado) Instituto de Pesquisas Tecnológicas, Universidade de São Paulo, São Paulo, 1999. 
INNOCRNTIINI, M. D. M., PANDOLFELLI, V. C. Permeability of porous ceramics considering the Klinkenberg and inertial effects. Journal of the American Society, p. 941-944, 2001.

JALBERT, M.; DANE, J. H. A handheld device for intrusive and nonintrusive field measurements of air permeability. Vadose Zone Journal, p. 611-617, 2003.

JANNOT, Y.; LASSEUX, D.; VIZÉ, G.; HAMON, G. A detailed analysis of permeability and Klinkenberg coeficient estimation from unsteady-state pulsedecay or draw-down experiments. International Symposium of the Society of Core Analysts. Calgary, Canada, p. 1-12, 2007.

JI, W.; DAHMANI, A.; AHLFELD, D. P.; LIN, J. D.; HILL, E. Laboratory study of air sparging: air flow visualization. Ground Water Monitoring and Remediation, $\mathrm{p}$. 115-126, 1993.

JOHNSON, P. C. Assessment of the contributions of volatilization and biodegradation to in situ air sparging performance. Environmental Science \& Technology, p. 276-281, 1998.

JOHNSON, R. L.; JOHNSON, P. C.; McWHORTER, D. B.; HINCHEE, R. E.; GOODMAN, I. An Overview of In Situ Air Sparging. Groundwater Monitoring Review, p. 127-135, 1993.

JOHNSTON, C. D.; RAYNER, J. L.; PATTERSON, B. M.; DAVIS, G. B. Volatilisation and biodegradegration during air sparging of dissolved BTEXcontaminated groundwater. Journal of Contaminant Hydroloy, p. 377-404, 1998.

JONES, F. O.; OWENS, W. W. A laboratory study of low-permeability gas sands. Journal of Petroleum technology, p. 1631-1640, 1980.

JONES, S. C. A rapid accurate unsteady-state Klinkenberg permeameter. Society of Petroleum Engineers Journal, p. 383-397, 1972.

LEESON, A.; et al. Air sparging design paradigm. Columbus, Ohio 43201: Battelle, 2002.

LI, S.; DONG, M.; LI, Z. Measurement and revised interpretation of gas behavior in tight reservoir cores. Journal of Petroleum Science and Engineering, p. 81-88, 2009.

LIBARDI, P. L. Dinâmica da água no solo. São Paulo: Edusp - Editora da Universidade de São Paulo, 2005.

LU, N., LIKOS, W. J., Unsaturated soil mechanics. John Wiley \& Sons, Inc, 2004.

LUNDEGARD, P. D.; LABRECQUE, D. Air sparging in a sandy aquifer (Florence, Oregon, U.S.A.): Actual and apparent radius of influence. Contaminan Hydrology, p. 1-27, 1995. 
LUNDEGARD, P. D.; ANDERSEN, G. Multiphase Numerical Simulation of Air Sparging Performance. Ground Water 34, p. 451-460, may-june 1996.

LUNDY, D. A.; GOGEL, A. J. Capabilities and limitations of Wells for detecting and monitoring liquid phase hydrocarbons. Second National Symposium on Aquifer Restoration, Ground Water Monitoring and Geophysical Methods, National Water Well Association, Las Vegas, p. 23-25, 1988.

MARINHO, F. A. M.; MORETTI, G. V. Implicações da técnica de aspersão de ar na estabilidade de taludes. COBRAMSEG. 2008.

MARLEY, M. C.; HAZEBROUCK, D. J.; WALSH, M. T. The application of in situ air spargings an inovative soils and ground water remediation technology. Ground Water Monitoring Remediation, Spring, p. 137-144, 1992.

MARULANDA, C. A study of air flow through saturated porous media and its applications to in-situ air sparging. Tese de Doutorado, Massachusetts: Massachusetts Institute of Technology, 2001.

MCPHEE, C. A.; ARTHUR, K. G. Klinkenberg permeability measurements: problems and pratical solutions. Edinburgh Petroleum Services Limited, UK, p. 371-391, 1991.

MICKELSON, G. Guidance for design.installation and operation of in situ air sparging systems. Manual. Madison: Wisconsin Department of Natural Resources, novembro de 2003.

MORAIS JÚNIOR, E. S. Comparação entre a utilização de ensaios piloto e modelos numéricos para a determinação do raio de influência de poços de extração de vapores em áreas contaminadas por hidrocarbonetos de petróleo. 2009, Dissertação (Mestrado) - Instituto de Pesquisas Tecnológicas, Universidade de São Paulo, São Paulo, 2009.

NAVAL FACILITIES ENGINEERING SERGVICE CENTER. Final air sparging guidance document. NFESC, Port Hueneme, Califórnia, 2001.

OLIVEIRA, O. M. Estudo sobre a resistência ao cisalhamento de um solo residual compactado não saturado. 2004, 330 p. Tese (Doutorado) - Escola Politécnica, Universidade de São Paulo, São Paulo, 2004.

PETERSON, J. W.; MURRAY, K. S.; TULU, Y.I; PEULER, B. D.; WILKENS, D. A. Air-flow geometry in air sparging of fine-grained sands. Hydrogeology Journal, $\mathrm{p}$. 168-176, 2001.

PETERSON, J. W., LEPCZYK, P. A.; LAKE, K. L. Effect of sediment size on area of influence during groundwater remediation by air sparging: a laboratory approach. Environmental Geology, p. 1-6, 1999. 
PETERSON, J. W.; DEBOER, M. J.; LAKE, K. L. A laboratory simulation of toluene cleanup by air sparging of water-saturated sands. Journal of Hazardous Material, p. 167-178, 2000.

PLUMMER, C. R.; NELSON, J. D.; ZUMWALT, G. S. Horizontal and vertical well comparison for in situ air sparging. Ground Water Monitoring Review, p. 91-96, 1997.

PREVEDELLO, C. L. Programa Splintex para estimar a curva de retenção de água a partir da granulometria (composição) dos solos - Versão 1.0, 2002. Publicação em meio magnético.

REDDY, K. R.; ADAMS, J. A. Effects of soil heterogeneity on airflow patterns and hydrocarbon removal during in situ air sparging. Journal of Geotechnical and Geoenvironmental Engineering, p. 234-247, 2001.

RUTHERFORD, K. W.; JOHNSON, P. C. Effects of process control changes on aquifer oxygenation rates during in situ air sparging in homogeneous aquifers. Ground Water Monitoring Review, p. 132-141, 1996.

SANCHES, V. L. Remediação de solos da formação São Paulo contaminados por vapores de gasolina. 2009, 120 p. Dissertação (Mestrado), Universidade de São Paulo, São Paulo, 2009.

SCANLON, B. R.; NICOT, J. P.; MASSMANN, J. W. Soil gas movement in unsaturated systems. In: Soil Physics Companion, p. 297-341. Washington, D.C.: WARRICK, ARTHUR W.; CRC Press, 2002.

SCHIMA, S.; LABRECQUE, D. J.; LUNDEGARD, P. D. Monitoring air sparging using resistivity tomography. Ground Water Monitoring Review, p. 131-138, 1996.

SILVA, A. P., LEÃO, T. P., TORMENA, C. A., GONÇALVES, A. C. A. Determinação da permeabilidade ao ar em amostras indeformadas de solo pelo método da pressão decrescente. Revista Brasileira de Ciência do Solo, p. 1535-1545, 2009.

SUTHERSAN, S. S. Remediation Engineering Design Concepts. Lewis, 1997.

TAITEL, Y., BORNEA, D., DUKLER, A.E. Modelling flow pattern transitions for steady upward gas-liquid flow in vertical tubes. AlChE Journal, 26, p. 345-354, 1980.

TEIXEIRA, P. F. Oxidação biologica do metano em coberturas de aterros de resíduos sólidos urbanos: dinâmica do processo e aspectos geotécnicos, 2008. 149 p. Tese (Doutorado) - Escola Politécnica, Universidade de São Paulo, São Paulo, 2008.

USACE (U.S. Army Corps of Engineers) Engineering and design in-situ air sparging (EM 1110-4005), 2008 Manual, Washington, DC. 
Capítulo 9 - Referências Bibliográficas

WEHRLE, K. In situ cleaning of CHC contaminated sites: model-scale experiments using air-injetion (in-situ stripping) method in granular soil. In: Arendt F., Hinsenveld, M., Van Den Brink, W. J. (eds) Contaminated Soils. Kluwer, Dordrecht, p. 1061-1062, 1990. 